\title{
Spot on: Managing Panama Disease of Bananas in the Philippines
}

Maricar Salacinas 


\section{Thesis committee}

\section{Promotor}

Prof.Dr Gerrit H.J. Kema

Special professor Tropical Phytopathology

Wageningen University \& Research

\section{Co-promotor}

Dr Harold J.G. Meijer

Senior Scientist, Biointeractions and Plant Health

Wageningen University \& Research

\section{Other members}

Prof.Dr André Drenth, The University of Queensland, Australia

Prof.Dr Jos M. Raaijmakers, The Netherlands Institute of Ecology, Wageningen, NL

Prof.Dr Paul C. Struik, Wageningen University and Research

Dr Sietze R. Vellema, Wageningen University and Research

This research was conducted under auspices of the graduate School of Experimental Plant Sciences (EPS). 


\title{
Spot on: Managing Panama Disease of banana in the Philippines
}

\author{
Maricar Salacinas
}

Thesis

submitted in fulfilment of the requirements for the degree of doctor at Wageningen University by the authority of the Rector Magnificus,

Prof. Dr. A.P. J. Mol,

in the presence of the

Thesis Committee appointed by the Academic Board

to be defended in public

on Tuesday 27 August 2019

at 1:30 p.m. in the Aula. 


\section{Maricar Salacinas}

Spot on: Managing Panama Disease of banana in the Philippines 180 pages.

PhD thesis, Wageningen University, Wageningen, the Netherlands (2019) with references, with summaries in English, Dutch and Bisaya

ISBN: $\quad 978-94-6332-540-0$

DOI: $\quad$ https://doi.org/10.18174/497746 


\section{Contents}

$\begin{array}{lll}\text { Chapter } 1 & \text { General Introduction } & 7\end{array}$

Chapter 2 A Loop-Mediated Isothermal Amplification assay based on $\quad 35$ unique markers derived from genotyping by sequencing data for rapid in-plant diagnosis of Tropical Race 4 in banana

Chapter 3 Epidemiology and management of Panama disease in the Mindanao Cavendish banana belt of the Philippines

Chapter 4 Efficacy of disinfectants against the causal agent of Panama disease in Cavendish banana

Chapter 5 Anaerobic soil disinfestation controls Panama disease caused by Tropical Race 4 in Cavendish bananas

Chapter 6 General Discussion

Summaries

About the author 

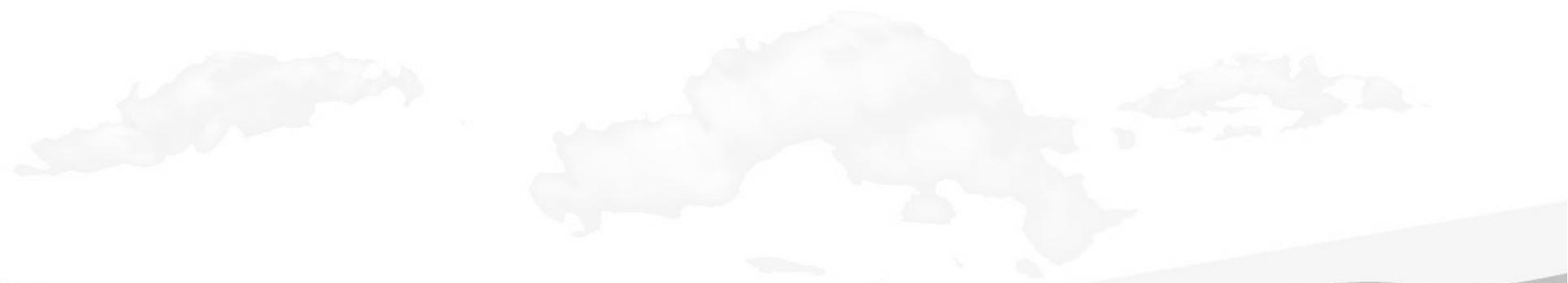

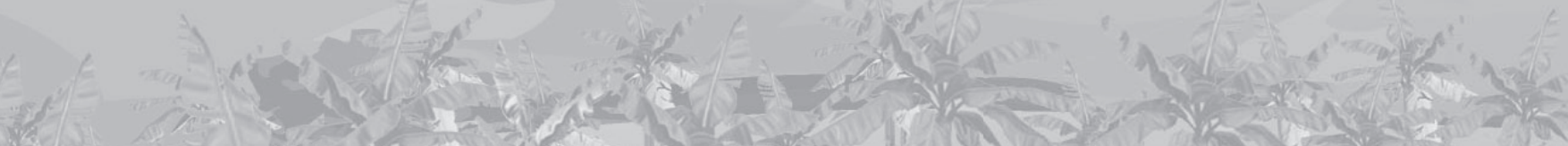

1.

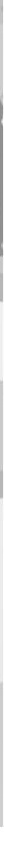




\section{CHAPTER 1}

General Introduction 



\section{Banana: a plant at risk}

Banana is a monoecious monocotyledonous plant belonging to the family Musaceae. It is the largest herbaceous plant in the world, which is often considered a tree as it grows normally up to approximately $5 \mathrm{~m}$ in height and is fairly robust. However, the stem is a pseudostem that grows from a corm (Simmonds, 1962; Swennen and Rosales, 1994; Swennen et al., 2011). The cultivated bananas we are now enjoying are mostly polyploids of either Musa acuminata $(A \mathrm{~A}, 2 \mathrm{n}=22)$ or natural hybrids with $M$. balbisiana $(\mathrm{BB}, 2 \mathrm{n}=22)($ Simmonds and Shepherd, 1955). The center of origin of banana is in Southeast Asia where diversity is greatest, including many different types of sweet dessert and cooking bananas (HeslopHarrison and Schwarzacher, 2007; Perrier et al., 2011; Simmonds and Shepherd 1955). From Southeast Asia, bananas were transported to East and West Africa by early human migration and then to the Americas during colonization, which eventually initiated the commercial cultivation of bananas (d'Hont et al., 2012; Koeppel, 2008; Marin et al., 1998; Perrier et al., 2011; Ploetz et al., 2003; Robinson and Sauco, 2010).

Of the approximately 1,000 banana cultivars identified in more than 150 countries, only a minority is cultivated. Global banana production relies on a few triploids ( $A A A, A A B, A B B$ ) accounting to $75 \%$ of the total production comprising Cavendish subgroups ( 20 cultivars, $46 \%$ ), plantains ( 120 cultivars, $15 \%$ ) and the East African highland bananas ( 150 cultivars, $39 \%$ ) (Lescot, 2017). These bananas are produced as food security and cash crop (Karamura et al., 1998) or for the export trade (Robinson and Sauco, 2010). In the Philippines, 87 banana cultivars are cultivated either as sweet dessert, cooking or dual-purpose bananas, of which 31 are unique compared to other banana cultivating countries in Southeast Asia (Valmayor et al., 2000). The major cultivars are the Cavendish varieties 'Grande Naine' and 'Williams' for the fresh export market. The local varieties Saba/Cardaba (ABB) are mostly used for the production of chips and crackers and Lakatan (AA), Bungulan (AAA), Latundan $(A A B)$ and 'Señorita' (AA) are cultivated for fresh export and local markets (Molina, 2004; Valmayor et al, 2000).

As bananas grow best in areas with sufficient water, it is now widely cropped in regions between $30^{\circ} \mathrm{N}$ and $30^{\circ} \mathrm{S}$ latitude in nearly 135 countries (Ploetz, et al., 2003). With a total annual production of more than 148 million tonnes (FAOSTAT, 2016), banana ranks high as a major food crop (Aurore et al., 2009). Of these, nearly $85 \%$ of the total production is for local consumption and only $15 \%$ represents export bananas for the international market (FAOSTAT, 2013). Countries like India, China, Philippines, Brazil and Indonesia are among the top producers. The starchy cooking bananas are a staple food for approximately 500 million people (Collins, 2014). In Uganda, banana is an important cash (Shively and Hao, 2012) and staple crop with daily consumption of approximately $1.6 \mathrm{~kg}$ per capita (Thornton and Cramer, 2012). It is a good source of carbohydrates, potassium, calcium, phosphorus and vitamin C, vitamin A, thiamine, riboflavin and niacin (Stover and Simmonds, 1987). The international trade in bananas augmented dramatically since the 1970s with Ecuador, the Philippines, Costa Rica, Guatemala, Colombia, Honduras, the Dominican Republic, Côte 
d'Ivoire, Mexico and the Canary Islands as key exporters. Together these countries exported 18.6 million tonnes in 2016, primarily to the United States of America, Europe, China, Japan, the Middle-East and the Republic of Korea (FAOSTAT, 2016).

Most edible cultivars are sterile with no or low seed set, and therefore vegetatively propagated using suckers or rhizomes (Ortiz et al., 1995; Simmonds 1962). Since the 1970s tissue culture dramatically impacted the banana business (Dore-Swamy et al., 1983; Gowen et al., 1995), resulting in the generation of millions of healthy plants that are shipped locally and internationally (Vuylsteke, 1989). This contributed to the development of a banana monoculture, which is vulnerable and prone to spreading diseases and pests. The genetic uniformity is a vehicle for the dissemination of major diseases that threaten the trade but also many locally produced varieties (Blomme et al., 2013; Dita et al., 2013; Garcia, 2019; Jones, 2002; Jones, 2009; Ploetz et al., 2015). Major viral and bacterial banana diseases include (Jones, 2009) banana bunchy top virus (BBTV), causing chlorosis of leaves and rosette growth and low yield (Hooks et al., 2008), banana mosaic virus (BMV) caused by cucumber mosaic virus, initiating characteristic linear patterns of chlorosis and mosaics in leaves and fruit (Jones, 2002) and banana bract mosaic virus (BBMV) transmitted by the aphid species Pentalonia nigronervosa, Aphis gossypii and Rhopalosiphum maidis, causing a reddish-brown mosaic in the pseudostem or long stripes scattered unevenly in the petiole and leaf lamina. The most important bacterial wilts are Moko disease that is caused by Ralstonia solanacearum biovar 1 race 2 making the pulp inedible due to hardening and discoloration of vascular tissue (Fegan, 2005; Hayward, 2006; Jones, 2009; Valdez, 1985) and Xanthomonas wilt caused by Xanthomonas vasicola pv. musacearum (Biruma et al., 2007). However, fungal diseases pose a major threat on global banana production. Black Sigatoka is caused by Pseudocercospora fijiensis - an economically important and pandemic disease affecting productivity and fruit quality (Arango et al., 2016; Diaz-Trujillo et al, 2017; Churchill, 2011; Marin et al., 2003; Romero and Sutton, 1997). Due to the extreme susceptibility of the major banana varieties and the globally reducing sensitivity to the major control agents (Chong, 2016; Diaz-Trujillo et al, 2017) and the associated environmental and occupational health concern, fungicides are the main means of control (Riséde et al., 2010).

\section{Panama disease}

\section{Biology and disease development}

Panama disease or Fusarium wilt is currently considered as the most important threat of global banana production (Ploetz et al., 2015). Previously, the causal agent was named Fusarium oxysporum f.sp. cubense - abbreviated as Foc - (E.F. Smith) W.C. Snyd. \& H.N. Hans. (Waite and Stover, 1960). However, over long it was recognized that Foc has a polyphyletic origin (Baayen et al., 2000), which essentially means that the genetic diversity in Foc is large and that some genotypes are closer to other Fusarium spp. than to each other (Laurence et al., 2014; O'Donnell et al., 1998). This underscored the need for improved classification, resulting in the recognition of vegetative compatibility groups (VCGs). However, these do not 
have a taxonomical relevance. Moreover, recent analyses showed that the number of VCGs is expanding with sample size (Ordóñez, 2018). Therefore, the taxonomical classification of Fusarium spp. causing Panama disease required a thorough revision. Maryani et al. (2019), therefore, used advanced genotyping technologies and detailed morphology to conclude that, indeed, Foc contains a suite of different Fusarium spp., which were consequently renamed (Maryani et al., 2019).

The causal fungi are soil-borne hypomycetes and related to more than 100 formae speciales of $F$. oxysporum that mostly initiate vascular wilts in flowering plants. Colony characteristics of the Fusarium spp. causing Panama disease are white to purple on PDA growing 4-7 mm a day at $24^{\circ} \mathrm{C}$ and with a moderate to profuse aerial mycelium (Leslie \& Summerell, 2006). They produce conidiospores comprising macro- and microconidia, which are initiated on branched and unbranched monophialides. Macroconidia are four to eight-sickled-shaped cells with sizes from 27-55 x 3.3-5.5 $\mu \mathrm{m}$ (Figure 1). Microconidia are one or two-celled spores ranging from 5-16 $\times$ 2.4-3.5 $\mu \mathrm{m}$ usually oval to kidney-shaped (Figure 1). These fungi also produce chlamydospores, normally 7-11 $\mu \mathrm{m}$ in diameter (Figure 1), which are resting spores that are formed - either singly or in pairs - on senescing hyphae or conidia under abiotic stress conditions (Ploetz et al., 2003). The Panama disease causing fungi probably co-evolved with their Musa hosts in the center of origin in Southeast Asia (O'Donnell et al.,1998; Groenewald et al., 2006; Fourie et al., 2009; Ordóñez et al., 2015; Mostert et al., 2017), resulting in a wide genetic diversity (Maryani et al., 2019). Horizontal gene transfer may play a significant role in the evolutionary history of Fusarium spp. associated with Panama disease (Fourie et al., 2009; Ma et al., 2010).

$\mathbf{A}$

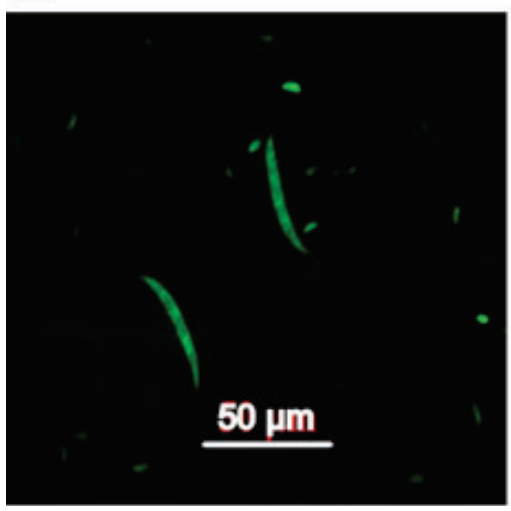

B

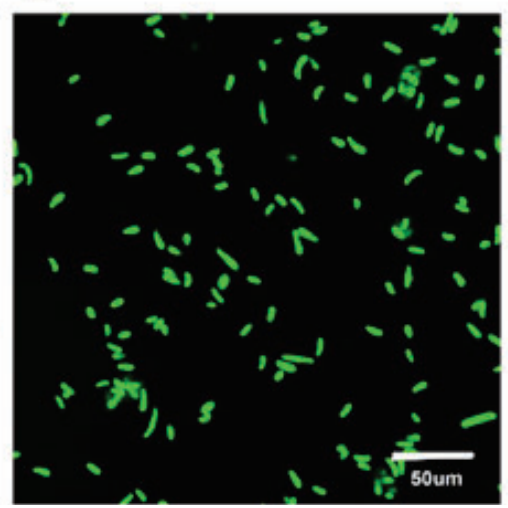

C

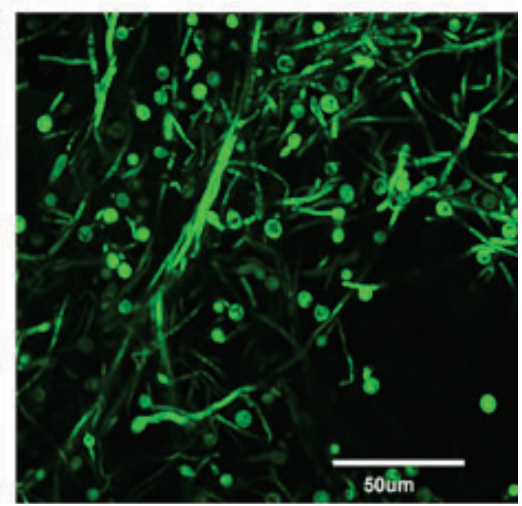

Figure 1. Morphology of Fusarium spp. spores marked with green fluorescent protein which includes macroconidia (A), microconidia (B), and chlamydospores (C) (Adopted from Guo et al., 2014). 


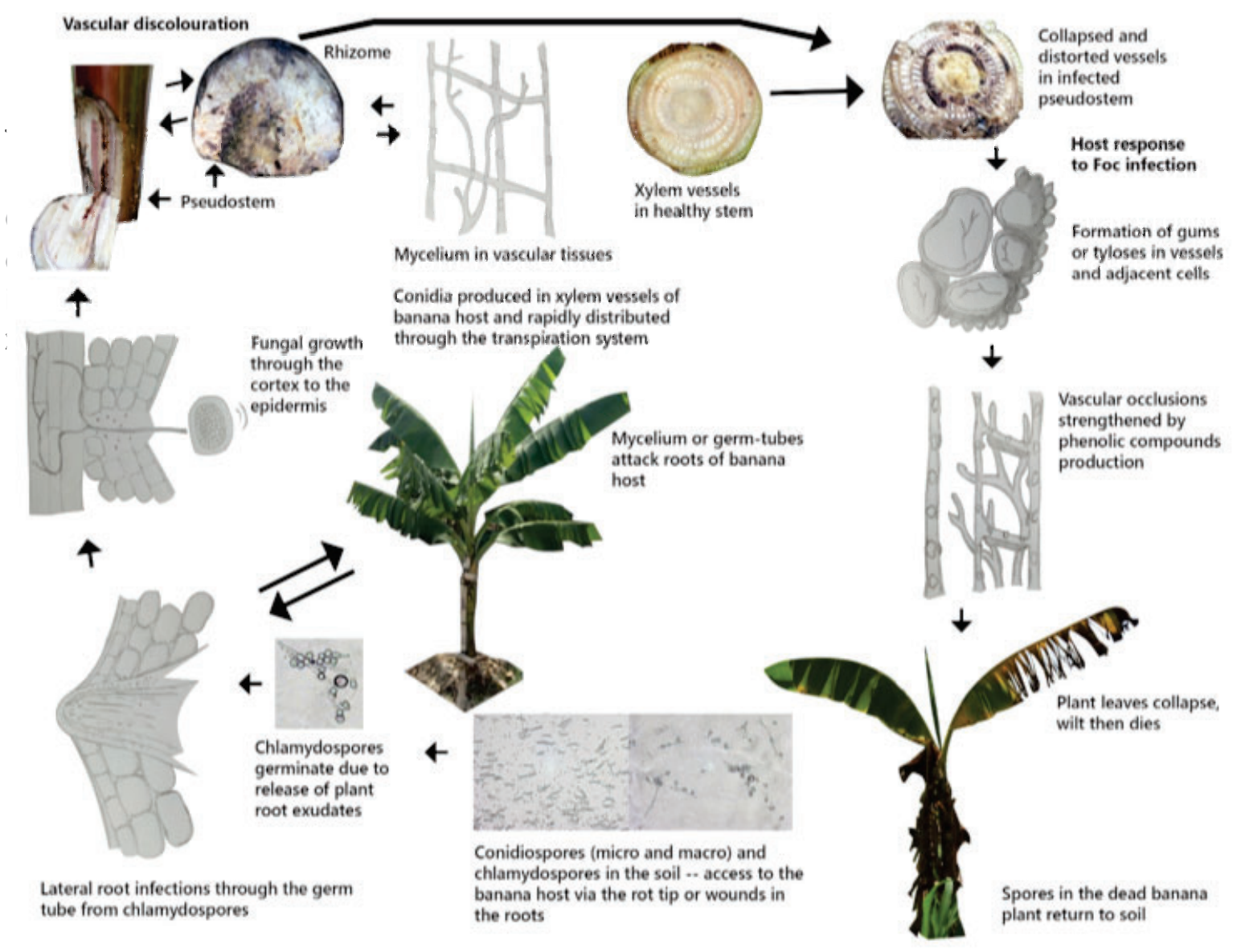

Figure 2. Infection cycle of Fusarium spp. in banana host.

The host, as an immediate response to non-self molecules, usually attempts to stop initial infections by vascular occlusions, such as the formation of gels, gums or tyloses, to prevent the advancement of the pathogen in the vessels (Beckman, 2000; Okubara \& Paulitz, 2005). This early pathogen-induced occlusion is strengthened by the production of phenolic compounds that in turn lignify these physical obstructions thus limiting the colonization of the pathogen in the xylem vessels. In the case of compatibility, such as the Cavendish-TR4 interaction, this will not work as the pathogen rapidly advances in the xylem ahead of this defence mechanism. In addition, conidia are also produced in the xylem vessels of the host and are distributed rapidly through the transpiration-driven waterflow in the plant, thereby intensifying the spread. Invasive hyphae are then produced that colonize new sites and thus repeat the cycle (Beckman, 1969; 1989; 1990; Vandermolen et al., 1977). During and after plant collapse the fungus also produces persistent chlamydospores, that can survive decades in the soil, on plant debris or in the rhizosphere (Schippers and Van Eck, 1981, Hennessy et al., 2005; Pittaway et al., 1999; Su et al.,1986). The external manifestation of Panama disease includes the chlorosis of the old leaves prominently around the margins (Figure 2), wilting and buckling of the leaves at the petiole base. As the disease progresses the leaves will collapse and form a "skirt" of dead leaves around the base of the plant. Splitting of the 
pseudostem is also associated with Panama disease. Internal symptoms are evident in the pseudostem (Figure 2) and rhizome (Figure 2 ) as initially yellow and subsequently reddishbrown to maroon discolorations that in severe cases will increase and stain deeply. In early stages of infection, Panama disease is often mistaken for nutritional problems, water stress or Moko disease. However, these do not usually result in discoloured vascular tissues and Moko disease normally affects the fruit, causes wilting and chlorosis on younger plants and merely discolours the centre of pseudostem (Ploetz, 2000; Ploetz et al. 2003; Stover 1962; Su et al., 1986; Vicente, 2004).

The genetic diversity for pathogenicity of Fusarium spp. infecting banana is limited. There are just four known races known, which is based on the response of a small panel of banana varieties to Fusarium spp. causing Panama disease (Stover, 1962). Species of race 1 are pathogenic on Gros Michel and also infect Silk (AAAA), Pome (ABB), Pisang Awak (ABB), Maqueno (AAB) and hybrid 'I.C.2' (AAAA) and is globally distributed. Strains of race 2 affect cooking bananas, particularly in the ABB subgroup and some tetraploids and is endemic to Central America. Race 3 is not any longer considered a banana pathogen as it attacks wild Heliconia spp. Finally, strains of race 4 are currently the most destructive and contagious attacking germplasm that is susceptible to races 1 and 2, as well as cultivars in the Cavendish group and many local varieties other cultivars such as cv. Pisang Masa (Garcia et al., 2019). Race 4 strains are divided in either subtropical race 4 (ST4), which can infect and cause disease under abiotic stress, and the aforementioned TR4 that threatens contemporary banana production and is a unique genotype (VCG01213).

\section{Dispersal and epidemiology}

Panama disease is globally distributed, particularly in the banana-producing regions both in the tropics and subtropics (Ploetz, 2000). Although the causal Fusarium spp. originate in Southeast Asia (Maryani et al., 2019), the earliest report of Panama disease was in Australia in 1876 (Bancroft, 1876). In the 1920s race 1 strains caused a major epidemic in Central America (Soluri, 2002; Marquardt, 2001; Ploetz, 2008; Ploetz, 2015; Stover, 1962) that wiped out at least 50,000 ha. of the Gros Michel based industry. Despite manifold agronomic measures to control the disease, the epidemic was eventually only quenched by adopting Cavendish varieties that are resistant to race 1 (Marquardt, 2001; Soluri, 2002). These saved and eventually globalized the industry. However, the appearance of TR4 in Southeast Asia recommenced this nightmare. Although precise figures are lacking, several hundred thousand hectares of banana plantations have currently been affected (Ordóñez et al., 2015). Cavendish infections were first observed in Taiwan and were most likely due to TR4 where it reached a peak in 1976 (Su et al., 1986) making them less competitive in the export trade. Since then, the dissemination has been poorly monitored. In the 1990s, TR4 infestation prompted the abandoning of Cavendish plantations in Sumatra, Java, Sulawesi, Halmahera and Papua in Indonesia. In Malaysia, TR4 was contained in the peninsular area (Molina et al., 2009). Cavendish was also attacked by TR4 in the Northern Territory of Australia (near Darwin) in the years 1977 through 1999. Early detection and 
strict implementation of quarantine policies impeded the further spread of the disease (Bentley et al., 2001), until TR4 surfaced in the banana belt of Northern Queensland in 2015 and 2017 (Dale, 2018; O'Neill et al., 2016; Australia Department of Agriculture and Water Resources). The movement of planting material and lack of strict quarantine regulations were hold responsible for the dissemination in China, reaching from the Eastern province of Fijian, to the southernly provinces Guangdong and Hainan, and henceforward to the South Western provinces Guangxi and Yunnan (Chittarath et al., 2017; Hung et al., 2017; Li et al., 2013; Molina et al., 2009; Mostert et al., 2017; Zheng et al., 2018). From there, TR4 has disseminated into the greater Mekong region with incursions in Vietnam, Laos and Myanmar (Zheng et al., 2018). Taken together with recent outbreaks in the Indian subcontinent, the Middle East, Africa and even the United Kingdom (Anonymous, 2018; García et al., 2014; Maymon et al., 2018; Ordóñez et al., 2016; Ordóñez et al., 2015; Ploetz et al., 2015b; Thangavelu et al., 2019) and recently in Colombia (https://www.sciencemag. org/news/2019/07/devastating-banana-disease-may-have-reached-latin-america-coulddrive-global-prices) (Figure 3), the danger of TR4 expansion cannot be underestimated and jeopardizes both the export industry as well as the livelihoods of many small holders. The above narrative, underscores that despite Panama disease is caused by a range of soilborne fungi, intra-and inter-continental migration has taken place and similar to other pests and diseases (Gurr et al., 2011; Fisher et al., 2012; Stuart et al., 2004), man apparently plays a significant role as a vector (Marin et al., 1998; Ploetz, 2015; Zheng et al., 2018). Irrespective of the absence of concrete scientific evidence, other factors have also been considered responsible for dispersal. Surface water movement such as irrigation water was deemed for the rapid spread of Panama disease (Su et al., 1986) as well as the movement of farm machineries, implements and soil. Root-to-root contact between diseased and healthy plants was deliberated. Additionally, weeds were considered as possible drivers of Panama disease spread because they can be reservoirs facilitating the lateral transmission of the causal agents (Hennessy et al., 2005; Pittaway et al., 1999; Vicente, 2004). Therefore, studying the epidemiology of Panama disease causing Fusarium spp. is a must. 


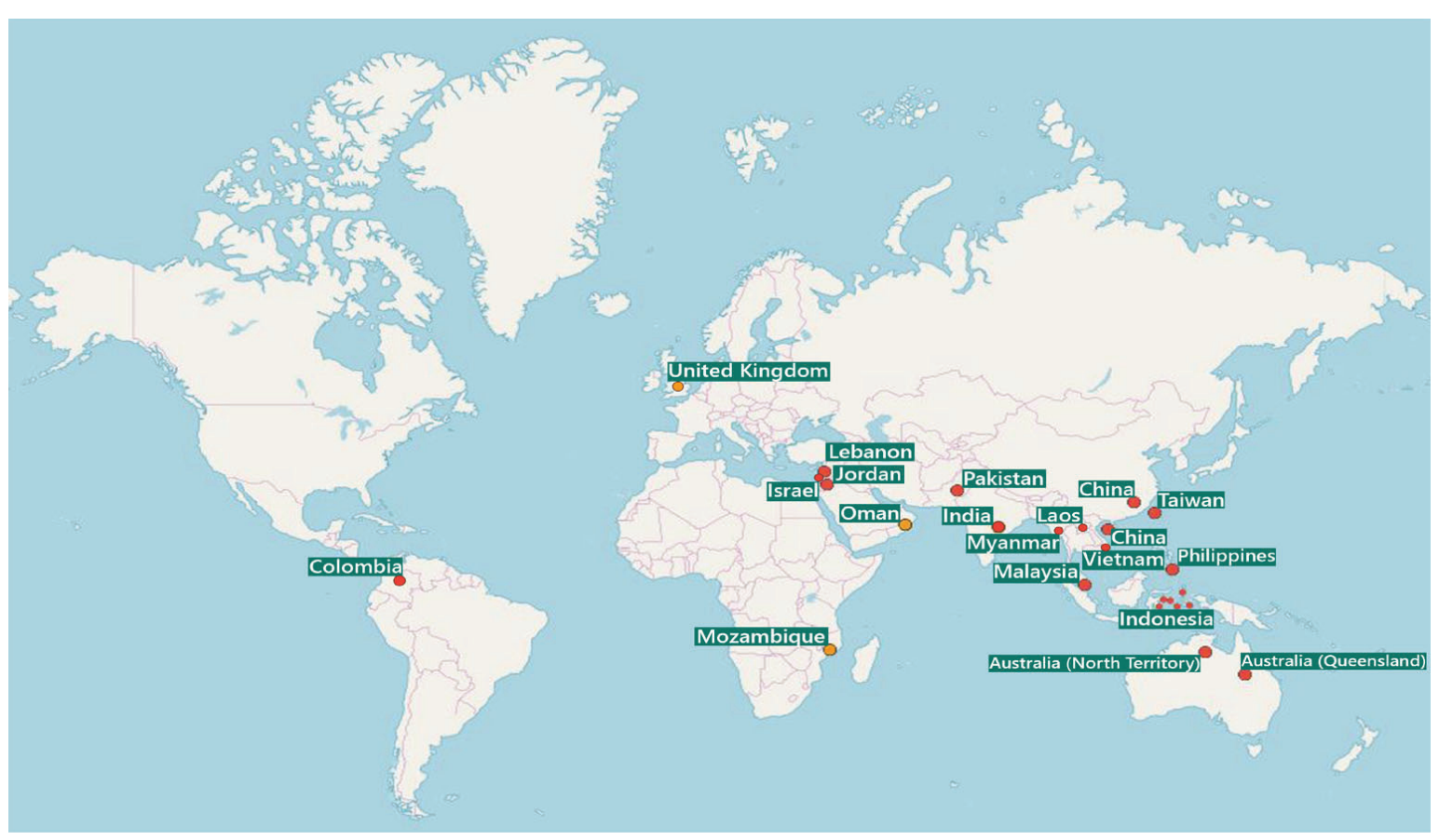

Figure 3. Global distribution of Fusarium odoratissimum tropical race 4. The presence in countries with red dots were confirmed while orange dots implies presence of TR4 but no formal publication (adapted from www.panamadisease.org).

The banana industry in the Philippines developed primarily after the decline of abaca, Musa textilis, as a fiber crop (Valmayor et al., 2002). This was due to the development of nylon fibers and hence the industry turned to Cavendish production in 1970s and developed to one of the major exporters, primarily to Japan, Korea, China and the Middle East (Philippine Banana Growers and Exporters Association, PBGEA). In the Philippines, different VCGs (such as 0122, 0123 and 0126), which are now recognized as F. phialophorum, F. oxysporum and F. purpurascens, respectively; Maryani et al., 2019) set off approximately 30,000 ha (sweet dessert bananas as cv. Cavendish, Latundan and Lakatan) in the years 1974 through 1991. This massive eradication was associated with water logging (Magnaye, 2001; Roperos and Magnaye, 1991), and the cooking banana Saba/Cardaba also succumbed to the disease. From the highlands, a more aggressive Fusarium infection was reported in Cavendish farms and later even at sea level that was later identified as TR4 (Molina et al. 2009). Panama disease rapidly reached economic proportions when it devastated commercial and smallscale banana plantations in Mindanao (Molina et al., 2008; Mostert et al., 2017). Currently, the government is intensifying its efforts to manage the disease together with manifold national and international partners (Philippines Department of Agriculture). However, the socio-economic impact of TR4 has continued to increase as the pathogen spreads to newly developed cultivation areas - or expansions - that are driven by the impact of Panama disease in China which translates to increased market demands. Unfortunately, there is currently 
no effective long-term disease management strategy at hand. Therefore, growers tend to accept any potential alternative to continue banana cropping, including the widely accepted replacement of Cavendish cultivars (Banana Asia Pacific Network, 2017), by the so-called Giant Cavendish Tissue Culture Variants (GCTCVs) developed by Taiwan Banana Research Institute. This germplasm, however, is at most less susceptible to TR4 and hence, only a temporary postponement of the tipping point of the epidemic (Dale et al., 2017). For those that depend on banana as cash or food security crop, such pompously advocated solutions are at most merely temporary and eventually inadequate alternatives that undermine trust in scientific research, which is the worst-case scenario for an ever expanding problem (Butler, 2013; Kema \& Weise, 2013; Ordóñez et al., 2015).

\section{Disease Detection}

In considering plant disease epidemiology i.e. studies of disease spread and pathogenic relationships, the unambiguous identification of causal agents is an absolute requirement, which is also a necessity for the implementation of quarantine measures (Jimenez-Diaz et al., 2015; Lin and Lin, 2016; McCartney et al., 2003). Although it is fairly difficult to identify symptoms during the early stage of infection, conventional identification of Panama disease relies on visual inspection in the field and or subsequent isolation of fungal strains and subsequent culturing, morphological identification and pathogenicity tests (Leslie \& Summerell, 2006). These methods are time consuming and depend largely on the expertise and accuracy of individuals performing the diagnosis (Lin and Lin, 2016; McCartney et al., 2003). Unfortunately, Panama disease symptoms can only be observed during advanced stages of pathogen infection (Ploetz, 2000) and classical methods for identification are frequently puzzling due to false positives or negatives. Therefore, the aforementioned VCG analyses, which is based on heterokaryon formation between compatible isolates sharing a common allele at each vic locus (Correll, 1991; Leslie, 1990; Leslie et al., 2007), truly supported identifications of particular genotypes such as VCG01213 that represents TR4. However, VCG analyses can significantly delay diagnosis due to the lack of tester sets and are overall time consuming (García-Bastidas et al., 2014; Leslie \& Summerell, 2006; Molina et al., 2009; Ordoñez, 2018). They are therefore not suitable for rapid action upon suspected TR4 incursions.

Molecular tools revolutionized epidemiological studies as they can pre-symptomatically detect pathogens potentially providing farmers with an effective management tool (Schaad et al., 2003). However, the specificity and sensitivity of these molecular diagnostics needs to be scrutinized before they can be used to better understand the temporal and spatial dynamics of pathogen dispersal (Lin and Lin, 2016; McCartney et al., 2003). Currently, DNAbased diagnostics for TR4 are available such as polymerase chain reaction (PCR) primers (Dita et al., 2010; Lin et al., 2009; Fraser-Smith et al., 2014), real time-PCR (Aguayo et al., 2017; Lin et al., 2013; Yang et al; 2015), loop mediated isothermal amplification (LAMP) (Li et al., 2013), real-time LAMP (Peng et al., 2014) and insulated isothermal PCR (Lin et al., 2016). These undoubtedly improved the detection capacity of TR4, but in many cases the 
specificity of these diagnostics was insufficient as race 4 strains comprised STR4 and TR4 that correspond to 10 different VCGs including VCG01213 (Buddenhagen, 2009; Maryani et al., 2019; Ordóñez, 2018). The TR4 primers of Dita et al. (2010) have proved the required specificity for TR4 across hundreds of different Fusarium strains (Maryani, 2019; Ordóñez, 2018) and were therefore commercialized to support the industry with a standardized protocol enabling comparison of data across laboratories (ClearDetections, http://www. cleardetections.com/index.php/home/). In all new suspected TR4 incursions these primers confirmed its presence and enabled the implementation of quarantine strategies (Dale et al., 2017; García et al., 2015; Maryani, 2019; Ordoñez et al., 2016; Zheng et al., 2018). Despite its accuracy, this diagnostic requires a laboratory and experimental skills. Therefore, an easy to use on-site diagnostic kit would facilitate the industry as well as advanced methods to detect TR4 in complex substrates such as soil, water or by swaps of farm implements. Such methods would greatly aid in charting the dispersal of TR4 propagules and could also support breeding programs if they enable quantification of the fungus.

\section{Disease management}

Currently, there are no commercially available fungicides to control the disease. Yet, many products are advocated as solutions for TR4, but their efficacy to control Panama disease has never been accurately demonstrated under field conditions (Belgrove et al., 2011). The majority of diseases caused by soil-borne pathogens is too complex to be controlled by traditional methods (Weller et al., 2002). Integrated disease control methods, however, that link novel technologies with traditional expertise and practice, provide an outlook to effectively manage these diseases. Panama disease is no exception as it cannot be directly controlled, unlike other banana diseases that can be directly managed with fungicides or biologicals (black Sigatoka) and physical (bunchy top disease) methods (Katan, 2000; Weller et al., 2002). For decades, scientists and agriculturists all over the world have tried to develop a cure for Panama disease, including the once preferred inundation (Marquardt, 2001; Soluri, 2002) but lacked the tools to actually measure the efficacy of the applied methods.

In the Philippines, disease management is practiced by chopping down infected plants, and covering the remains with rice hulls or wood that is set on fire for slow release sanitation by heat. Alternatively, plants are left standing until they die, a strategy practiced in China. These methods have significant drawbacks as they do not kill (all) inoculum in the soil (across different depths) and have no effect on nearby asymptomatic plants. Chemical measures by using methyl bromide (Herbert and Marx, 1990) or carbendazim and potassium phosphonate (Lakshamanan et al., 1986) are hazardous for the environment and do not give satisfactory disease control (Prather, et al., 1984; Ristaino and Thomas, 1997; Duniway, 2002; Subbarao, 2002; Fravel et al., 2003). Biocontrol by using antagonistic microorganisms implicated from suppressive soils have also been studied and include the effects of actinomycetes (Meredith, 1943; 1946; Cao et al., 2005), Pseudomonas fluorescens (Akila et al., 2011; Nel et al., 2006; Raguchander et al., 1997; Saravanan et al., 2003; Sivamani and Gnanamanickam, 1988), P. aeruginosa (Saravanan and Muthusamy, 2006), Trichoderma 
viride (Raguchander et al., 1997; Thangavelu and Mustaffa, 2010), T. harzianum (Thangavelu et al., 2003), Streptomyces sp. (Getha and Vikineswary, 2002; Getha et al., 2005), Bacillus subtilis (Akila et al., 2011), Serratia sp. (Ting et al., 2008), and Penicillium citrinum (Ting et al., 2012). Non-pathogenic strains of Fusarium have been investigated (Forsyth et al., 2006; Gerlach et al., 1999; Nel et al., 2006; Thangavelu and Jayanthi, 2009; Ting et al., 2009) and have shown promising results for Fusarium wilt control in various crops. Generally, these rhizosphere microorganisms work directly through competition in the rhizosphere and plant tissues for nutrients, oxygen or space and physical destruction of the fungal cell wall or indirectly by the induction of systemic resistance (Fravel et al., 2003). In general, lack of consistency and poor activity in a variety of soil environments impede the adoption of the aforementioned biocontrol agents in commercial production systems, which can be attributed to the soil microbial and chemical structure and the reduced survival of these microorganisms in banana roots (Belgrove et al., 2011). Besides, the safety issue of releasing non-pathogenic strains of Fusarium in soil should also be noted as it might cause non-target organism displacement, toxicity or pathogenicity as well as allergies in humans and animals (Fravel et al., 2003; Ma et al., 2010). Recently, the utility of Chinese leek was suggested to have an inhibitory effect on TR4 (Huang et al.,2012), but applications have not stopped the Chinese TR4 epidemic and hence its efficacy under field conditions awaits demonstration. Consecutive applications of biofertilizer (BIO) seems a promising method to control Panama disease in newly established farms (Fu et al., 2016) but further sustainable disease management needs to be proven. Finally, Huang et al. (2015) showed that biological soil disinfestation or anaerobic soil disinfestation (ASD), employing various organic substrates, reduces Fusarium inoculum and consequently disease occurrence in naturally infested soil, but it also requires further studies, particularly on the type of organic matter used and its scalability.

Employing resistant banana genotypes is a long-term solution for disease control (Ploetz, 1990; Vicente, 2004), and Cavendish cultivation is the best example as it stopped the Panama disease epidemic in Central America in the late 1960s until this day. However, replacing Cavendish with germplasm resistant to TR4 is a challenge as it is not readily available and breeding for resistance is time consuming and hence, not feasible for solving acute disease issues in global banana production (Dale et al., 2017). The Taiwanese GCTCV somaclones (Hwang and Ko, 2004; Molina et al., 2016; Mostert et al., 2017) that are currently planted in TR4 infested areas (Agriculture Magazine, 2014; Banana Asia Pacific Network, 2016, 2017) are neither a sustainable solution due to significant genotype $x$ environment interactions in the Philippines and elsewhere (Ploetz, 2015), apart from rejections in important markets. Other ongoing efforts to generate TR4 resistant banana germplasm (De Beer et al., 2001; Ho et al., 2001; Dale et al., 2017) clearly indicate the increased interest in banana cropping and its sustainability.

This overview clearly indicates the nearly uncontrollable status of TR4 under field conditions. As long as resistant cultivars are not available, integrated disease control comprising wellorganized monitoring, quarantine and eradication procedures, is the way to go. This can 
be implemented by delimiting the movement of planting materials, people and farm machineries and equipment, animals and water flow around the infested areas, but requires also efficient tools to detect and quantify TR4 to evaluate the efficacy of these measures.

\section{Scope of the thesis}

Based on this overview I have identified major gaps in understanding the dynamics of inoculum dispersal and epidemiology of TR4 in the Philippines. First of all, the disease needs to be diagnosed. Surveys in southern and northern Mindanao have shown that many growers particularly small-scale hardly recognize the disease, let alone know how to manage it. Moreover, even industrial Cavendish growers and governmental institutions lack laboratory services to diagnose the disease. Available diagnostics (Dita et al., 2010; http:// www.cleardetections.com/index.php/service/fusariumwiltdiseasekit/) require laboratory facilities and materials that are not commonly available in Mindanao. We therefore considered that an on-site diagnostic platform would facilitate rapid in-field diagnosis and ideally should target another genomic region which would facilitate double checking for any positive detection of TR4. Since we are dealing with a large contemporary problem in Mindanao, as banana exports of the Philippines are gradually declining (FAOSTAT, 2017), I considered to focus on the most imminent practical question that urgently need data driven underpinning to enhance Panama disease management, irrespective whether these are Cavendish or local banana small holder plantations. Therefore, my overall hypothesis is that the currently practiced disease management strategies are ineffective or insufficiently applied as the incidence of Panama disease in Mindanao has significantly increased since its first incursion in 2009. This then has led me to a range of sub-hypotheses that are addressed in experiments to obtain (1) data on the dispersal of TR4 in and by contaminated soil, water, and alternative hosts; (2) information on the efficacy of disinfectants, commonly applied in Philippine banana farms, which are used as a first line of defence against TR4 dispersal at entry points in plantations and farm units and (3) to investigate whether there would be a way to effectively reduce inoculum in the soil. Taken together, such data would significantly improve Panama disease management in the Philippines, both in large-scale plantations and small holder plots, as well as any other country facing the TR4 threat.

Chapter 1 describes the biology of banana, its cultivation and importance as cash and staple crop, as well as the importance of various diseases. Panama disease, caused by soil-borne Fusarium spp. is discussed in detail. Gaps of knowledge are identified and addressed to improve current management practices by taking into account past and present methods to diagnose the disease as well as aspects of dispersal, epidemiology and overall disease development.

In Chapter 2, I focus on the possibility and necessity to develop a rapid on-site DNAbased diagnostic for TR4, ideally based on novel genomics positions. I used genotyping by sequencing through Diversity Array Technology (DArT) and subsequent bioinformatics analyses which enabled the identification of new unique genomic regions to specifically 
detect TR4 in a complex biological environment. I used these data in a loop-mediated isothermal amplification detection system that was implemented as diagnostic tool for TR4 in plant tissues both in greenhouse and field trials in the Philippines. This contributes to charting the advancement and direction of TR4 dissemination.

Chapter 3 addresses a range of epidemiological aspects of TR4 in Mindanao. I hypothesized that TR4 is disseminated across the soil profile which affects the efficacy of any control method. However, detecting the fungus at various layers in the soil does not necessarily implicate survival. In other words, detecting DNA is no proof for living inoculum. Using various techniques, I determined the vertical soil profiling of TR4 in naturally infested soils and substantiated that contaminated irrigation water is a potential source of disease spread. Indeed, field sanitation by burning either rice hull or wood reduces but does not eradicate TR4 inoculum. Finally, I showed that non-host weeds can be infected with TR4, which further complicates risk and disease management.

In Chapter 4, I question the assumption that disinfectants are the first line of defence against further spread of TR4. If the efficacy against different propagules is poor, such disinfectants have limited value in disease control. Therefore, tests were carried out on mycelia, conidia, and chlamydospores - both in suspension and in soil - at different concentrations and exposure times. Additionally, the corrosiveness of these disinfectants against aluminium and iron metals was examined. By comparing data collected after treating contaminated soil as well as the purified biological propagules, I conclude that cleaning is better than disinfecting as the critical exposure time for disinfecting soil is too long. I complement this observation with monitoring the real-time exposure time to disinfectants at farm gate quarantine baths - such as tire and footwear baths - and the corresponding costs of installing and maintaining these quarantine baths in a commercial banana plantation. The overall conclusion is that these practices are not efficacious and can be considered as "window dressing". These results will force both the banana industry as well as small holders to evaluate and alter their cleaning methods.

Chapter 5 I explore a method for Fusarium spp. inoculum reduction in soil. Rather than inundation I used a commercial product whose decomposition rapidly reduces oxygen in the soil and simultaneously produces a range of gases that affect aerobic microorganisms. After determining the efficacy under laboratory conditions, I hypothesized that applying it under field conditions would significantly reduce TR4 inoculum. Indeed, using anaerobic soil disinfestation in the naturally infested soil in the Philippines reduced the TR4 concentration. Replanting these treated plots with Cavendish banana plants showed a significant slower recurrence of the disease after one cropping cycle compared to controls.

Chapter 6 is an overarching discussion of the information gathered in this PhD project. It elaborates on past and current knowledge of the epidemiology of TR4 in Mindanao and how disease control can be optimized to reduce further dissemination of the disease by appropriately deploying or adapting current control measures (burning) and the 
implementation of quarantine measures. The importance of early detection employing accurate and specific diagnostic tools for water, soil and plant contamination is an underlying principle for any subsequent quarantine measure. As long as adequately resistant banana varieties are not available, short-term disease management practices should be integrated for maximum efficacy and be based on reliable data. 


\section{References}

Agriculture Magazine (2014) Another Banana Variant Resists Fusarium Wilt Disease. Accessed at https://www.agriculture.com.ph/2017/09/03/another-banana-variant-resists-fusarium-wiltdisease/

Aguayo J, Mostert D, Fourrier-Jeandel C, Cerf-Wendling I, Hostachy B, Viljoen A, et al. (2017) Development of a hydrolysis probe-based real-time assay for the detection of tropical strains of Fusarium oxysporum f. sp. cubense race 4. PLoS One 12(2).

Akila, R., Rajendran, L., Harish, S., Saveetha, K., Raguchander, T. and Samiyappan, R. (2011) Combined application of botanical formulations and biocontrol agents for the management of Fusarium oxysporum f.sp. cubense (Foc) causing Fusarium wilt in banana. Biological Control 57:175-183.

Anonymous (2009) Philippine Department of Agriculture-Agriculture and Fisheries Information Service.

Aurore, G., Parfait, B. and Fahrasmane, L. (2009) Bananas, raw materials for making processed food products. Trends in Food Science \& Technology 20: 78-91.

Banana Asia Pacific Network (2016). Bright Prospect of Managing Foc TR4 in the Philippines: Use of Resistant Cavendish Somaclone Varieties. Accessed at http://banana-networks.org/ Bapnet/2016/02/22/fusarium-wilt-resistant-cavendish-cultivars/

Banana Asia Pacific Network (2017). Varieties Resistant to Fusarium oxysporum f.sp. cubense is commercially used in the Philippines against Panama Disease epidemics. Accessed at http:// banana-networks.org/Bapnet/2017/11/29/varieties-resistant-fusarium-oxysporum-f-spcubense-commercially-used-philippines-panama-disease-epidemics/

Beckman, C.H. (1969) Plasticizing of walls and gel induction in banana root vessels infected with Fusarium oxysporum. Phytopathology 59:1477-1483.

Beckman, C.H. (1989) Colonization of the vascular system of plants by fungal wilt pathogens: a basis for modeling the interactions between host and parasite in time and space. In: Tjamos, E.C. and Beckman, C.H. (eds.). Vascular wilt diseases of plants. Springer-Verlag, Heidelberg, Berlin, pp.19-32.

Beckman, C.H. (1990) Host responses to the pathogen. In R.C. Ploetz (Ed.) Fusarium wilt of banana (pp. 107-114). St. paul:APS.

Beckman, C.H. and Talboys, P.W. (1981) Anatomy of resistance. In: mace, M.E., Bell, A.A. and Beckman, C.H. Fungal Wilt Diseases of Plants.Academic Press: New York, USA.

Bentley, S., Moore, N.Y., Pegg, K.G., Gerlach, K.S. and Smith, L.J. (2001) Genetic characterization and detection of Fusarium wilt. In: Molina, A.B., Nik Masedk, N.H. and Liew, K.W. (eds.). Banana Fusarium wilt management: towards sustainable cultivation. Proceedings of the international workshop on the banana Fusarium wilt disease held in Genting highlands resort, Malaysia, 18-20 October 1999. INIBAP, Los Banos, Laguna, Philippines.

Biruma, M., Pillay, M., Tripathi, L., Blomme, G., Abele, S....Eden-Green, S. (2007) Banana Xanthomonas wilt: a review of the disease, management strategies and future research directions. African Journal of Biotechnology 6(8) 953-962.

Blok, W.J., Lamers, J.G., Termorshuizen, A.J. and Bollen, G.J. (2000) Control of soilborne plant pathogens by incorporating fresh organic amendments followed by tarping. Phytopathology 90:253-259.

Blomme, G., Ploetz, R., Jones, D., De Langhe, E., Price, N., Gold, C., . . Buddenhagen, I. (2013). A historical overview of the appearance and spread of Musa pests and pathogens on the African continent: highlighting the importance of clean Musa planting materials and quarantine measures. Annals Applied Biology 162(1), 4-26. 
Brake, V.M., Pegg, K.G., Irwin, J.A.G., Chaseling, J. (1995) The influence of temperature, inoculums level and race of Fusarium oxysporum f.sp. cubense on the disease reaction of banana cv. Cavendish. Australian Journal of Agricultural Research 46:673-685.

Buddenhagen, I.W. (2009) Understanding strain diversity in Fusarium oxysporum f.sp. cubense and history of introduction of 'tropical race 4' to better manage banana production. In: Jones, D. and Van den Bergh, I. (eds.) Proc.IS on Banana Crop Prot., Sust. Prod. And Impr. Livelihoods, White River, South Africa. ISHS Acta Horticulturae 828,193-204.

Burdon, J.J and Thrall, P.H. (2007) Pathogen evolution across the agro-ecological interface: implications for disease management. Blackwell Publishing 1:57-65.

Bureau of Agricultural Statistics. (2011) Available at http://www.bas.gov.ph/.

Butler, D. (2013). Fungus threatens top banana. Nature 504, 195-196.

Cao, L., Qui, Z.,You, J., Tan, H. and Zhou,S. (2005) Isolation and characterization of endophytic streptomycete antagonists of fusarium wilt pathogen from surface-sterilized banana roots. FEMS Microbiology Letters 247:147-152.

Chittarath, K., Mostert, D., Crew, K. S., Viljoen, A., Kong, G., Molina, G., \& Thomas, J. E. (2017). First report of Fusarium oxysporum f.sp. cubense tropical race 4 (VCG 01213/16) associated with Cavendish bananas in Laos. Plant Disease 449.

Collins, S. (2014) Banana: staple food for 500 million people. CGIAR. http://dialogues.cgiar.org/blog/ banana-staple -food-for-500-million-people/

Cook, R.J. and Baker, K.F. (1983) The nature and practice of biological control of plant pathogens. St. Paul, MN, USA: The American Phytopathological Society.

Dale, James. (2018) The vulnerability of banana to globally developing disease threats. International congress on plant pathology, Boston, USA

Dale, J., James, A., Paul, JY., Khanna, H., Smith, M., Echeverria, SP., Garcia-Bastidas, F., Kema, G., Waterhouse, P., Mengersen, K. and Harding, R. (2017) Transgenic Cavendish bananas with resistance to Fusarium wilt tropical race 4. Nature Communications 8:1496.

De Beer, Z.C., Severn-Ellis, A. and Husselman, J.H. (2001) Preliminary assessment of Cavendish banana clones for resistance/tolerance to Fusarium wilt. In: Molina, A.B., Nik Masedk, N.H. and Liew, K.W. (eds.). Banana Fusarium wilt management: towards sustainable cultivation. Proceedings of the international workshop on the banana Fusarium wilt disease. INIBAP, Los Banos, Laguna, Philippines, pp. 194-200.

D’Hont, A., Denoeud, F., Aury, J. M., Baurens, F. C., Carreel, F., Garsmeur, O., . . Wincker, P. (2012). The banana (Musa acuminata) genome and the evolution of monocotyledonous plants. Nature 488(7410), 213-217.

Diaz-Trujillo, C., Chong, P., ....Kema, G.H.J. (2107) A new mechanism for reduced sensitivity to demethylation-inhibitor fungicides in the fungal banana black Sigatoka pathogen Pseudocercospora fijiensis. Molecular Plant Pathology 19(6).

Di Pietro, A., Madrid, M. P., Caracuel, Z., Delgado-Jarana, J., \& Roncero, M. I. (2003). Fusarium oxysporum: exploring the molecular arsenal of a vascular wilt fungus. Molecular Plant Pathology 4(5), 315-325.

Diener, A. (2012). Visualizing and quantifying Fusarium oxysporum in the plant host. Molecular Plant Microbe Interaction 25(12), 1531-1541.

Dita, M. A., Garming, H., Van den Bergh, E. B., Staver, C., \& Lescot, T. (2013). Banana in Latin America and the Caribbean: current state, challenges and perspectives Acta Hort, 986(Proc. Int. ISHSProMusa Symp. on bananas and plantains: towards sustainable global production and improved uses), 365-380.

Dita, M.A., Waalwijk, C., Buddenhagen, I.W., Souza, M.T. Jr., and Kema, G.H.J. (2010) A molecular diagnostic for tropical race 4 of the banana fusarium wilt pathogen. Plant Pathology 59:348-357. 
Dore-Swamy, R., Srinivasa,-Rao, N.K., and Chacko, E.K. (1983) Tissue-culture propagation of banana. Scientia Horticulturae 18(3): 247-252.

Duniway,J.M.(2002) Status of chemical alternatives to methyl bromide for pre-plant fumigation of soil. Phytopathology 92:1337-1343.

FAOSTAT. Food and Agricultural Organization of the United Nations Statistical Databases, Production Statistics, Crop-Banana, World production. Available at http://faostat.fao.org/

Fegan, M. (2005) Bacterial wilt diseases of banana: evolution and ecology. In: Allen, C., Prior, P., and Hayward, A.C. (eds), Bacterial Wilt Disease and the Ralstonia solanacearum Species Complex. APS Press, St. Paul, USA, pp 379-386.

Fisher, M.C., Henk, D.A., Briggs, C.J., Brownstein, J.S., Madoff, L.C., McCraw, S.L. and Gurr, S.J. (2012) Emerging fungal threats to animal, plant and ecosystem health. Nature 484:186-194.

Forsyth, L.M., Smith, L.J., Aitken, E.A.B. (2006) Identification and characterization of non-pathogenic Fusarium oxysporum capable of increasing and decreasing Fusarium wilt severity. Mycological Research IIO:929-935.

Fourie, G., Steenkamp, E.T., Gordon, T.R., Viljoen, A. (2009) Evolutionary relationships among the vegetative compatibility groups of Fusarium oxysporum f.sp. cubense. Applied and Environmental Microbiology 75:4770-81.

Fraser-Smith, S., Czislowski, E., Meldrum, R.A., Zander, M., O'Neill, W., Balali, G.R., and Aitken, E.A. 2014. Sequence variation in the putative effector gene $S I X 8$ facilitates molecular differentiation of Fusarium oxysporum f. sp. cubense. Plant Pathology 63:1044-1052.

Fravel, D., Olivain, C. and Alabouvette, C. (2003) Fusarium oxysporum and its biocontrol. New Phytologist 157:493-502.

Fu, L., Ruan, Y., Tao, C., Li, R., and Shen, Q. (2016) Continuous application of bioorganic fertilizer induced resilient culturable bacteria community associated with banana Fusarium wilt suppression. Scientific reports 6: 27731.

García, F., Ordóñez, N., Konkol, J., Al-Qasim, M., Naser, Z., Abdelwali, M., ... Kema, G. H. J. (2014). First report of Fusarium oxysporum f.sp. cubense tropical race 4 associated with Panama disease of banana outside Southeast Asia. Plant Disease 98(5) 694.

Garcia, F., Ordoñez , N., Konkol, J., Al-Qasim, M., Nazer, Z., Abdelwali, M., Salem, N., Waalwijk, C., Ploetz, R., and Kema G.H.J. (2015) First report of Fusarium oxysporum f.sp. cubense tropical race 4 associated with Panama disease in banana outside southeast Asia. Plant disease 98 (5): 694.

Garcia, F.A., Bakry, F., Irish, B.M. and Kema, G.H.J. (2019) Resistance in banana to Fusarium spp. causing Panama disease: Triploid, Diploid and Hybrid accessions. PhD thesis, Wageningen University and Research, Wageningen, The Netherlands.

Gerlach, K.S., Bentley, S., Moore, N.Y., Aitken, E.A.B. and Pegg, K.G. (1999) Investigation of nonpathogenic strains of Fusarium oxysporum for suppression of Fusarium wilt of banana in Australia. In: Alabouvette C. (ed). Second International Fusarium Workshop. Dijon, France.

Getha, K. And Vikineswary, S. (2002) Antagonistic effects of Streptomyces violaceusniger strain G10 on Fusarium oxysporum f.sp. cubense race 4: indirect evidence for the role of antibiosis in the antagonistic process. Journal of Industrial Microbiology 28:303-310.

Getha, K., Vikineswary, S., Wong, W.H., Seki, T., Ward, A., Goodfellow, M. (2005) Evaluation of Streptomyces sp. Strain g10 for suppression of Fusarium wilt and rhizosphere in pot-grown banana plantlets. Journal of Industrial Microbiology 32:24-32.

Goud, J.C., Termorshuizen, A.J., Blok, W.J., and van Bruggen, A.H.C. (2003) Long-term effect of biological soil disinfestations on Verticillium wilt. Plant Disease 88:688-694.

Gowen, S., Israeli, Y., Lahav, E., and Reuveni, O. (1995) In vitro culture of bananas. Bananas and plantains pp.147-178. Springer, The Netherlands. 
Griffiths, L.J., Anyim, M., Doffman, S.R., Wilks, M., Millar, M.R., and Agrawal, S.G. (2006) Comparison of DNA extraction methods for Aspergillus fumigates using real-time PCR. Journal of Medical Microbiology 55:1187-1191.

Guo L, Han L, Yang L, Zeng H, Fan D, et al. (2014) Genome and Transcriptome Analysis of the Fungal Pathogen Fusarium oxysporum f. sp. cubense Causing Banana Vascular Wilt Disease. PLoS One 9(4).

Gurr, S., Samalova, M., Fisher, M. (2011) The rise and rise of emerging infectious fungi challenges food security and ecosystem health. Fungal Biology Reviews 25:181-188.

Guo, L., Han, L., Yang, L., Zeng, H., Fan, D., Zhu, Y., . . Huang, J. (2014). Genome and transcriptome analysis of the fungal pathogen Fusarium oxysporum f.sp. cubense causing banana vascular wilt disease. PLoS One 9(4), 1-17.

Guo, L., Yang, L., Liang, C., Wang, G., Dai, Q., \& Huang, J. (2015). Differential colonization patterns of bananas (Musa spp.) by physiological race 1 and race 4 Isolates of Fusarium oxysporum f.sp. cubense. Phytopathology 1-11.

Hayward, A.C. (2006) Fruit rots of banana caused by Ralstonia solanacearum race 2: questions of nomenclature, transmission and control. Infomusa 15(1-2).

Hennessy, C., Walduck, G., Daly, A. and Podovan, A. (2005) Weed hosts of Fusarium oxysporum f.sp. cubense tropical race 4 in Northern Australia. Australasian Plant Pathology 34:115-117.

Herbert, J.A. and Marx, D. (1990) Short-term control of Panama disease of bananas in South Africa. Phytophylactica 22:339-340.

Heslop-Harrison, J. S., \& Schwarzacher, T. (2007). Domestication, genomics and the future for banana. Annals of Botany London 100(5), 1073-1084.

Ho, Y.W., Mak, C. and Liew, K.W. (2001) Selection of banana cultivars for tolerance to Fusarium wilt race 4 in Malaysia. In: Molina, A.B., Nik Masedk, N.H. and Liew, K.W. (eds.). Banana Fusarium wilt management: towards sustainable cultivation. Proceedings of the international workshop on the banana Fusarium wilt disease. INIBAP, Los Banos, Laguna, Philippines, pp. 234-242.

Hooks, C.R.R, Wright, M.G., Kabasawa, D.S. Manandhar, R., and Almeida, R.P.P. (2008) Effect of banana bunchy top virus on morphology and growth characteristic of banana. Annals of Applied Biology 153:1-9.

Huang, S-C. and Ko, W-H. (2004) Cavendish banana cultivars resistant to Fusarium wilt acquired through somaclonal variation in Taiwan. The American Phytopathological Society 88:580-588.

Huang, Y.H., Wang, R.C., Li, C.H., Zuo, C.W., Wei, Y.R., Zhang, L. and Yi, G.J. (2012) Control of Fusarium wilt in banana with Chinese leek. European Journal of Plant Pathology 134:87-95.

Hung, T. N., Hung, N. Q., Mostert, D., Viljoen, A., Chao, C. P., \& Molina, G. (2017). First report of Fusarium wilt on Cavendish bananas, caused by Fusarium oxysporum f.sp. cubense tropical race 4 (VCG 01213/16), in Vietnam. Plant Disease 448.

Jansma, J.E., Vlaming, E.A.C., Boer, M. De and Blok, W. (2001) Biologische grondontsmetting. Ekoland, the Netherlands 21:26-27.

Jimenez-Diaz, R.M., Castillo, P., Jimenez-Gasco, M.M., Landa, B.B., Navas-Cortes, J.A. (2015) Fusarium wilt of chickpeas: biology, ecology and management. Crop Protection 73:16-27.

Jones, D.R. (2002) Risk of spread of banana diseases in international trade and germplasm exchange. In: Proceedings XV ACORBAT Meeting 2002. Cartagena de Indias, Colombia. pp 105-113. 
Jones, D.R. (2009) Disease and pest constraints to banana production. Acta Horticulturae 828:21-36.

Karamura, E., Frison, E., Karamura, D.A. and Sharrock, S. (1998) Banana production system in eastern and southern Africa. Paper presented at the Bananas and food security, INIBAP, Montpellier.

Kema, G. H. J., \& Weise, S. (2013). Pathogens: Appeal for funds to fight banana blight. Nature 504(7479), 218.

Klimek-Ochab, M., Brzezinska-Rodak, M., Zymanczyk-Duda, E., Lejczak, B. and Kafarski, P. (2011) Comparative study of fungal cell disruption-scope and limitations of the methods. Folia Microbiology 56:469-475.

Kubota, R., Vine, B.G., Alvarez, A.M. and Jenkins, D.M. (2008) Detection of Ralstonia solanacearum by loop-mediated isothermal amplification. The American Phytopathological Society 98:1045-1051.

Lakshamanan, P., Selvaraj, P. and Shanmugan, N. (1986) An effective method for the control of Panama disease of banana. Proceedings of Seminar on Management of Soil-Borne Diseases of Crop Plants. Tamil Agricultural University. Coimbatore.

Lamers, J.G., Blok, W.J., and Termorshuizen, A.J. (2000) Biological soil disinfestations to control Fusarium oxysporum f.sp. asparagi in Dutch asparagus fields. In: Abstracts of Symposium on chemical and non-chemical soil and substrate disinfestations, Torino, Italy,p.15.

Lamers, J.G., Runia, W.T., Molendijk, L.P.G. and Bleeker, P.O. (2010) Perspectives of Anaerobic soil disinfestations. In: Gamliel et al. (eds.). Proc. VII IS on Chem. And Non-chem. Soil and Substrate Disinfestation. Acta Horticulturae 883.

Lescot, T. (2017) 'Banane.Diversite genetique Fruitrop (Ed. Francaise) 248:102.

Leslie, J. F., \& Summerell, B. (2006). The Fusarium Laboratory Manual: Blackwell Publishing.

Li, B., Du, J., Lan, C., Liu, P., Weng, Q. and Chen, Q. (2013) Development of a loop-mediated isothermal amplification assay for rapid and sensitive detection of Fusarium oxysporum f.sp. cubense race 4. European Journal of Plant Pathology 135:903-911.

Li, B., Du, J., Lan, C., Liu, P., Weng, Q., and Chen, Q. 2013. Development of a loop-mediated isothermal amplification assay for rapid and sensitive detection of Fusarium oxysporum f. sp. cubense race 4 European Journal of Plant Pathology 135:903-911.

Li, C. Y., Mostert, G., Zuo, C. W., Beukes, I., Yang, Q. S., Sheng, O., . . Yi, G. J. (2013). Diversity and distribution of the banana wilt pathogen Fusarium oxysporum f.sp. cubense in China. Fungal Genetics and Biology 3(2), 1-6.

Li, C., Chen, S., Zuo, C., Sun, Q., Ye, Q., Yi, G., \& Huang, B. (2011). The use of GFP-transformed isolates to study infection of banana with Fusarium oxysporum f.sp. cubense race 4. European Journal of Plant Pathology 131(2), 327-340.

Li, C., Chen, S., Zuo, C., Sun, Q., Ye, Q., Yi, G., and Huang, B. (2011) The use of GFP-transformed isolates to study infection of banana with Fusarium oxysporum f. sp. cubense race 4. European Journal Plant Pathology 131: 327-340.

Lin, Y.H, Lin, Y.J., Chang, T.D., Hong, L.L., Chen, T.Y., and Chang, P.F.L. (2016) Development of a TaqMan probe-based insulated isothermal polymerase chain reaction (iiPCR) assay for detection of Fusarium oxysporum f. sp. cubense race 4. PLoS One 11:e0159681.

Lin, Y.H., Chang, J.Y., Liu, E.T., Chao, C.P., Huang, J.H., and Chang, P.F.L. 2009. Development of a molecular marker for specific detection of Fusarium oxysporum f. sp. cubense race 4. European Journal Plant Pathology 123:353-365. 
Lin, Y.H., Su, C.C., Chao, C.P., Chen, C.Y., Chang, C.J., Huang, J.W., and Chang, P.F.L. 2013. A molecular diagnosis method using real-time PCR for quantification and detection of Fusarium oxysporum $\mathrm{f}$. sp. cubense race 4. European Journal Plant Pathology 135:395-405.

Lin, Y-H., Chang, J-Y., Liu, E-T., Chao, C-P., Huang, J-W., and Chang, P-F.L. (2009) Development of a molecular marker for specific detection of Fusarium oxysporum f.sp. cubense race 4. European Journal Plant Pathology 123:353-365.

Lin,Y-H. and Y-J Lin (2016) Recent Developments in the Molecular Detection of Fusarium oxysporum f.sp. cubense. Journal of Nature and Science 2(10):e239.

Ma, L.J., van der Does, H.C., Borkoich, K.A........Rep, M. (2010) Comparative genomics reveals mobile pathogenicity chromosomes in Fusarium. Nature 464 (7287): 367-373.

Magnaye, L.V. (2001) Status of Panama disease in the Philippines. In: Molina, A.B., Nik Masedk, N.H., and Liew, K.W (eds.) Banana Fusarium wilt management: towards sustainable cultivation. INIBAP, Los Baňos, Laguna. pp. 50-57.

Marin, D. H., Sutton, T. B., \& Barker, K. R. (1998). Dissemination of bananas in Latin America and the Caribbean and its relationship to the occurrence of Radopholus similis. Plant Disease 82(9), 964-974.

Marín, D.H., Romero, R.A., Guzmán, M., and Sutton, T.B. (2003) Black Sigatoka: an increasing threat to banana cultivation. Plant Disease 87:208-222.

Marquardt, S. (2001) "Green Havoc": Panama disease, Environmental Change and Labor Process in the Central American Banana Industry. The American Historical Review 106 (1): 49-80.

Maryani, N (2018) Phylogeny and genetic diversity of the banana Fusarium wilt pathogen Fusarium oxysporum f.sp. cubense in the Indonesian centre of origin. PhD thesis, Wageningen University and Research, Wageningen, The Netherlands.

Maryani, N., Lombard, L., Poerba, Y.S., Subandiyah, S., Crous, P.W. and Kema, G.H.J. (2019) Phylogeny and genetic diversity of the banana Fusarium wilt pathogen Fusarium oxysporum f.sp. cubense in the Indonesian centre of origin. Studies in Mycology 92:155-194.

Maymon, M. Shpatz, U., Shpatz, U., Harel, , Y.M., Levy, E., Elkind, , G., Teverovsky, E.,..... Israeli, Y. and Freeman, S. (2018) First Report of Fusarium oxysporum f. sp. Cubense Tropical Race 4 Causing Fusarium Wilt of Cavendish Bananas in Israel. Plant Disease 102 (12: 2655.

McCartney, H.A., Foster, S.J., Fraaije, B.A. and Ward, E. (2003) Molecular diagnostics for fungal plant pathogens. Pest Management Science 59:129-142.

Meredith, C.H. (1943) The antagonism of soil organisms to Fusarium oxysporum f.sp. cubense. Phytopathology 34:426-429.

Meredith, C.H. (1946) Soil actinomycetes applied to banana plants in the field. Phytopathology 36:983-987.

Termorshuizen, A>J., van Bruggen, A.H.C. and Blok, W.J. (2007) Biological Soil Disinfestation (BSD), a new control method for potato brown rot, caused by Ralstonia solanacearum race 3 biovar 2 . European Journal Plant Pathology 117:403-415.

Middelberg, A.P. (1995) Process-scale disruption of microorganisms. Biotechnology Advances 13(3):491-551.

Molina, A.B. (2004) The National Repository, Multiplication and Dissemination Centers: An instrument to the banana development program in Asia and the Pacific. Advancing banana and plantain R\&D in Asia and the Pacific. Proceedings of the $2^{\text {nd }}$ BAPNET Steering Committee meeting in Jakarta, Indonesia, 6 - 9 October 2003. A.B. Molina, V.N.Roa, I. van den Bergh, M.A.G. Maghuyop and K.H. Borromeo (eds) 166p. 
Molina, A.B., Fabregar, E.G., Sinohin, V.O., Yi, G., and Viljoen, A. (2009) Recent occurrence of Fusarium oxysporum f.sp. cubense tropical Race 4 in Asia. Acta Horticulturae 828:109-115.

Molina, A.B., Sinohin, V.O., Fabregar, E.G., Ramillete, E.B., Loayan, M.M. and Chao, C.P. (2016) Field resistance of Cavendish somaclonal variants and local banana cultivars to tropical race 4 of Fusarium wilt in the Philippines. Acta Horticulturae 1114.

Momma, N., Kobara, Y., Uematsu, S., Kita, N., and Shinmura, A. (2013) Development of biological soil disinfestations in Japan. Applied Microbiology and Biotechnology 97:3801-3809.

Momma, N., Yamamoto, K., Simandi, P., Shishido, M. (2006) Role of organic acids in the mechanisms of biological soil disinfestations (BSD). Journal of General Plant Pathology 72:247-252.

Moore, N. Y., Bentley, S., Pegg, K. G. and Jones, D. R. (1995) Fusarium Wilt of Bananas. Musa Disease Fact Sheet No. 5 INIBAP.

Mostert, D., Molina, A. B., Daniells, J., Fourie, G., Hermanto, C., Chao, C. P., . . Viljoen, A. (2017). The distribution and host range of the banana Fusarium wilt fungus, Fusarium oxysporum f.sp. cubense, in Asia. PLoS One 12(7), 1-24

Muller, F-M.C., Werner, K.E., Kasai, M., Francesconi, A., Chanock, S.J. and Walsh, T.J. (1998) Rapid extraction of genomic DNA from medically important yeasts and filamentous fungi by high-speed cell disruption. Journal of Clinical Microbiology 36:1625-1629.

Nagamine, K., Kuzuhara, Y. and Notomi, T. (2002) Isolation of single-stranded DNA from loop-mediated isothermal amplification products. Biochem. Biophys. Res. Commun. 290:1195-1198.

$\mathrm{Nel}$, B., Steinberg, C., Labuschagne, N. and Viljoen, A. (2006) The potential of non-pathogenic Fusarium oxysporum and other biological control organisms for suppressing Fusarium wilt of banana. Plant Pathology 55:217-223.

Notomi, T., Okayama, H., Masubuchi, H., Yonekawa, T., Watanabe, K., Amino, N. and Hase, T. (2000) Loop-mediated isothermal amplification of DNA. Nucleic Acids Research 28:E63.

O'Donnell., K., Rooney, A.P., Proctor, R.H., Brown D.W., McCormick S.P., Ward T.J., Frandsen, RJ.N., Lysoe, E., Rehner, S.A., Aoki, T., Robert, V.A.R.G., Crous, P.W., Groenewald, J.Z., Kang, S., and Geiser, D.M. (2013) Phylogenetic analyses of RPB1 and RPB2 support a middle Cretaceous origin for a clade comprising all agriculturally and medically important fusaria. Fungal Genetics and Biology 52: 20-31.

O'Donnell., K., Kistler, H.C. Cigelnik, E. and Ploetz, R. (1998) Multiple evolutionary origins of the fungus causing Panama disease of banana: Concordant evidence from nuclear and mitochondrial gene genealogies. Proceedings of the National Academy of Sciences 95: 2044-2049.

O'Neill, W. T., Henderson, J., Pattemore, J. A., O'Dwyer, C., Perry, S., Beasley, D. R., et al. (2016). Detection of Fusarium oxysporum f. sp. cubense tropical race 4 strain in northern Queensland. Australasian Plant Disease Notes. 11:33.

Ordóñez, N. (2018) The phylogeography of the banana Fusarium wilt pathogen Fusarium oxysporum f.sp. cubense. PhD thesis, Wageningen University and Research, Wageningen, The Netherlands.

Ordóñez, N., García-Bastidas, F., Laghari, H. B., Akkary, M. Y., Harfouche, E. N., al Awar, B. N., \& Kema, G. H. J. (2016). First report of Fusarium oxysporum f.sp. cubense tropical race 4 causing Panama disease in Cavendish bananas in Pakistan and Lebanon. Plant Disease 100(1), 209.

Ordóñez, N., Seidl, M. F., Waalwijk, C., Drenth, A., Kilian, A., Thomma, B. P., . . Kema, G. H. J. (2015). Worse comes to worst: Bananas and Panama disease-when plant and pathogen clones meet. PLoS Pathogen 11(11), 1-7. 
Ortiz, R., Ferris, R.S.B., and Vuylsteke, D.R. (1995) Banana and plantain breeding. In: Gowen, S. (ed.). Bananas and Plantains. Chapman and Hall, London.

Pegg. K.G., Moore, N.Y., and Bentley, S. (1996) Fusarium wilt of banana in Australia: a review. Australian Journal of Agricultural Research 47:637-650.

Peng J., Zhang, H., Chen, F., Zhang, X., Xie, Y., Hou, X., Li, G., and Pu, J. 2014. Rapid and quantitative detection of Fusarium oxysporum f. sp. cubense race 4 in soil by real-time fluorescence loopmediated isothermal amplification. Journal of Applied Microbiology 117:1740-1749.

Peng, J., Fan, Z. and Huang, J. (2012) Rapid detection of banana streak virus by loop-mediated isothermal amplification assay in South China. Journal of Phytopathology 160:248-250.

Peng,J., Shi, M., Xia, Z., Huang, J. and Fan, Z. (2012) Detection of cucumber mosaic virus isolates from banana by one-step real-time loop-mediated isothermal amplification. Archives of Virology 157:2213-2217.

Peng,J., Zhang, J., Xia, Z., Li, Y., Huang, J. and Fan, Z. (2012) Rapid and sensitive detection of banana bunchy top virus by loop-mediated isothermal amplification. Journal of Virological Methods 185:254-258.

Perrier, X., De Langhe, E., Donohue, M., Lentfer, C., Vrydaghs, L., Bakry, F., ... Denham, T. (2011). Multidisciplinary perspectives on banana (Musa spp.) domestication. Proceedings of National Academy of Science 108(28), 11311-11318.

Perrier, X., De Longhe, E., Donohue, M., et al. (2011) Multidisciplinary perspectives on banana (Musa spp.) domestication. PNAS :1-8.

Pittaway, P.A., Nasir, N. and Pegg, K.G. (1999) Soil receptivity and host-pathogen dynamics in soils naturally infested with Fusarium oxysporum f.sp. cubense, the cause of Panama disease in bananas. Australian Journal of Agricultural Research 50:623-628.

Ploetz, R. C. (2015a). Fusarium Wilt of Banana. Phytopathology 105(12), 1512-1521.

Ploetz, R.C. (2015b) Management of Fusarium wilt of banana: a review with special reference to tropical race 4. Crop Protection 73:7-15.

Ploetz, R., Freeman, S., Konkol, J., Al-bed, A., Naser, Z., Shalan, K., Barakat, R., and Israeli, Y. (2015) Tropical race 4 of Panama disease in the Middle East. Phytoparasitica 43:283-293.

Ploetz, R.C. (1990) Variability in Fusarium oxysporum f.sp. cubense. Canadian Journal of Botany 68:1357-1363.

Ploetz, R.C. (2000) Panama disease: a classic and destructive disease of banana. In: Plant Health Progress.

Ploetz, R.C. (2005) Panama disease, an old enemy rears its ugly head. Parts 1 and 2. In: Plant Health Progress.

Ploetz, R.C. (2006) Fusarium wilt of banana is caused by several pathogens referred to as Fusarium oxysporum f.sp. cubense. The American Phytopathological Society 96:653-656.

Ploetz, R.C. (2008) Tropical race 4 of Panama Disease: A Dangerous Threat to Sustainable Production of Banana and Plantain. Caribbean Food Crops Society, Miami.

Ploetz, R.C. (2009) Pathogen diversity: contributions to applied and basic banana research. In: Jones, D. and Van den Bergh, I. (eds.) Acta Horticulturae 828.

Ploetz, R.C. and Pegg, K.G. (1997) Fusarium wilt of banana and Wallace's line: Was the disease originally restricted to his Indo-Malayan region? Australasian Plant Pathology 26:239-249. 
Ploetz, R.C. and Pegg, K.G. (1999) Fusarium wilt. In: D.R. Jones (ed.). Diseases of banana. CAB International, Wallingford, Oxon, UK. Pp143-159.

Ploetz, R.C., Thomas, J.E. and Slabaugh, W.R. (2003) Diseases of banana and plantains. In: Ploetz, R.C (ed.) CAB International. Diseases of Tropical Fruit Crops.

Podovan, A., Henessey, C. and Walduck, G. (2003) Alternative hosts of Fusarium oxysporum f.sp. cubense tropical race 4 in Northern Australia. In: $2^{\text {nd }}$ International Symposium on Fusarium wilt on banana. PROMUSA-INIBAP/EMBRAPA. Salvador de Bahia, Brazil, 22-26 Sept.

Prather, M.J. McElroy, M.B. and Wofsy, S.C. (1984) Reductions in ozone at high concentrations of stratospheric halogens. Nature 312:227-231.

Raguchander, T., Jayashree, K. and Samiyappan, R. (1997) Management of Fusarium wilt of banana using antagonistic microorganisms. Journal of Biological Control 11:101-105.

Riséde, J-M., Lescot, T., Cabrera JC., et al. (2010) Challenging short and mid term strategies to reduce the use of pesticides in banana production. (ed ENDURE).

Ristaino, J.B. and Thomas W. (1997) Agriculture, methyl bromide, and the ozone hole: can we fill the gaps. Plant Disease 81:954-975.

Robinson, J. C., \& Sauco, G. V. (2010). Bananas and plantains. Wellingford, Oxfordshire, UK: CABI.

Romero, R.A. and Sutton, T.B. (1997) Sensitivity of Mycosphaerella fijiensis, causal agent of Black Sigatoka of banana, to propiconazole. Phytopathology 87:96-100.

Roperos, N.I and Magnaye, L.V. (1991) Status of banana disease in the Philippines. In: Valmayor, R.V., Umali, B.E. and Bejosano, C.P. (eds.). Banana diseases in Asia and the Pacific. Proceedings of a technical meeting on banana diseases affecting banana and plantain in Asia and the Pacific. INIBAP, Montpellier. Brisbane, Australia, 15-18 April 1991. 180p.

Saravanan, T. and Muthusamy, M. (2006) Influence of Fusarium oxysporum f.sp. cubense (E.F. Smith) Snyder and Hansen on 2,4-diacetylphloroglucinol production by Pseudomonas fluorescens in banana rhizosphere. Journal of Plant Protection Research 46:241-254.

Saravanan, T., Muthusamy, M. and Marimuthu, T. (2003) Development of integrated approach to manage the fusarial wilt of banana. Crop Protection 22:1117-1123.

Schaad, N. W., Frederick, R. D., Shaw, J., Schneider, W. L., Hickson, R., Petrillo, M. D., \& Luster, D. G. (2003). Advances in molecular-based diagnostics in meeting crop biosecurity and phytosanitary issues. Annual Review Phytopathology 41, 305-324.

Schippers, B. and van Eck, W.H. (1981) Formation and survival of chlamydospores in Fusarium. In: Nelson, P.E., Tousson, T.A. and Cook, R.J. (eds.). Fusarium: Diseases, Biology and Taxonomy. Pennsylvania State University Press, Pennsylvania, pp. 250-260.

Science Magazine. (2019) Devastating banana disease may have reached Latin America, could drive up global prices. Accessed at https://www.sciencemag.org/news/2019/07/devastating-bananadisease-may-have-reached-latin-america-could-drive-global-prices

Shinmura, A. (2004) Principle and effect of soil sterilization method by reducing the redox potential of soil. The Phytopathological Society of Japan (PSJ) Soilborne Disease Workshop Report 22:212.

Shively, G. and Hao, J. (2012) A review of agriculture, food security and human nutrition issues in Uganda, p.28 Purdue University, Department of Agricultural Economics.

Simmonds, N. W. and Sheperd, K. (1955) The taxonomy and origins of cultivated bananas. Biological Journal of the Linnean Society 55:302-312. 
Sivamani, E. and Gnanamanickam, S.S. (1988) Biological control of Fusarium oxysporum f.sp. cubense in banana by inoculation with Pseudomonas fluorescens. Plant Soil 107: 3-9.

Soluri, J. ( 2002). Accounting for taste: Export bananas, mass markets, and Panama disease. Environmental History 7( 3), 386- 410.

Stover, R.H. (1962) Fusarial wilt (Panama disease) of bananas and other Musa species. Kew, UK: Commonwealth Mycological Institute.

Stover, R.H. and Simmonds, N.W. (1987) Bananas $3^{\text {rd }}$ edition. Longmans Scientific and Technical, London, UK.

Stuart, S. N., Chanson, J. S., Cox, N.A., Young, B.E., Rodrigues, A.S.L., Fischman, D. L. and Waller, R.W. (2004) Status and Trends of Amphibian Declines and Extinctions Worldwide. Science 306 (5702) 1783-1786.

Su, H.J., Hwang,S.C., Ko, W.H. (1986) Fusarial wilt of Cavendish bananas in Taiwan. Plant Disease 70:814-818.

Subbarao, K.V. (2002) Methyl bromide alternatives - meeting the deadline. Phytopathology 92:13341343.

Swennen, R. and Vuylsteke, D. (1993) Breeding Black Sigatoka resistant plantains with a wild banana. Tropical Agriculture 70:74-77.

Thangavelu, R., Palaniswami, A., Doraiswamy, S. and Velazhan, R. (2003) The effect of Pseudomonas fluorescens and Fusarium oxysporum f.sp. cubense on induction of defense enzymes and phenolics in banana. Journal of Plant Biology 46:107-112.

Thangavelu, R. and Jayanthi, A. (2009) RFLP analysis of r-DNA-ITS regions of native non-pathogenic Fusarium oxysporum isolates and their field evaluation for the suppression of Fusarium wilt disease of banana. Australasian Plant Pathology 38:13-21.

Thangavelu, R. and Mustaffa, M.M. (2010) A potential isolate of Trichoderma viride NRCB1 and its mass production for the effective management of Fusarium wilt disease in banana. Tree and Forestry Science and Biotechnology 4 (Special issue 2): 76-84.

Thangavelu, R., Mostert, D., Gopi, M., Ganga Devi, P., Padmanaban, B., Molina, A.B. and Viljoen, A. (2019) First detection of Fusarium oxysporum f. sp. cubense tropical race 4 (TR4) on Cavendish banana in India. European Journal of Plant Pathology.

Thanning, C. And Gerhardson, B. (2001) Reduced sclerotial soil-longevity by whole-crop amendment and plastic covering. Journal of Plant Diseases and Protection 108:143-151.

Thornton, P., \& Cramer, L. (2012). Impacts of climate change on the agricultural and aquatic systems and natural resources within the CGIAR's mandate. Paper presented at the CCAFS Working Paper 23. CGIAR Research Program on Climate Change, Agriculture and Food Security (CCAFS), Copenhagen, Denmark.

Ting, A.S.Y., Mah, S.W. and Tee, C.S. (2012) Evaluating the feasibility of induced resistance by endophytic isolate Penicillium citrinum BTF08 as control mechanism for Fusarium wilt in banana plantlets. Biological Control 61:155-159.

Ting, A.S.Y., Meon, S., Kadir, J., Son Radu, S., and Singh, G. (2009) Endophytic microorganisms as potential growth promoters of banana. Biological control 53:541-553.

Vakili, N.G. (1965) Fusarium wilt resistance in seedlings and mature plants of Musa species. Phytopathology 55:135-140.

Valdez, R.B. (1985) Bacterial wilt in the Philippines. In: Proceedings of an international workshop held at PCARRD, Los Baños, Philippines. pp 49-56. 


\section{Chapter 1}

Valmayor, R.V., Jamaluddin, S.H., Silayoi, B., Kusumo, S., Danh, L.D., Pascua, O.C., and Espino, R.R.C. (2000) Banana cultivar names and synonyms in Southeast Asia. International Network for the Improvement of Banana and Plantain-Asia and the Pacific Office, Los Banos, Laguna, Philippines.

Valmayor, R.V., Espino, R.R.C. and Pascua, O.C. (2002) The wild and cultivated bananas of the Philippines. International Network for the Improvement of Banana and Plantain-Asia and the Pacific Office, Los Banos, Laguna, Philippines.

VanderMolen, G.E., Beckman, C.H. and Rodehorst, E. (1977) Vascular gelation: a general response phenomenon following infection. Physiological and Plant Pathology 11: 95-110.

Vicente, L.P. (2004) Fusarium wilt (Panama Disease) of bananas: an updating review of the current knowledge on the disease and its causal agent. ACORBAT.

Vuylsteke, D.R. (1989) Shoot-tip Culture for the Propagation, Conservation and Exchange of Musa Germplasms. p: 56. IBGR, Rome.

Waite, B. H., \& Stover, R. H. (1960) Studies on Fusarium wilt of bananas, VI. Variability and cultivar concept in Fusarium oxysporum f. sp. cubense. Canadian Journal of Botany 38, 985-994.

Waite, B.H. and Dunlap, V.C. (1953) Preliminary host range studies with Fusarium oxysporum f.sp. cubense. Plant Disease 37:79-80.

Weller, D.M., Raaijmakers, J.M., McSpadden Gardener, B.B. and Thomashow, L.S. (2002) Microbial populations responsible for specific soil suppresiveness to plant pathogens. Annual Review of Phytopathology 40:309-48.

Yadeta, K. A., \& Thomma, B. P. (2013). The xylem as battleground for plant hosts and vascular wilt pathogens. Front Plant Science 4:1-12.

Yang, L.Sun, L., Ruan, X.,Qiu, D., Chen, D., Cai, X., and Li, H. (2015) Development of a single-tube duplex real-time fluorescence method for the rapid quantitative detection of Fusarium oxysporum f. sp. cubense race 1 (FOC1) and race 4 (FOC4) using TaqMan probes. Crop Protection 68: 27-35.

Zhang, X., Zhang, H., Pu, J., Qi, Y., Yu, Q., Xie, Y., and Peng, J. 2013. Development of a real-time fluorescence loop-mediated isothermal amplification assay for rapid and quantitative detection of Fusarium oxysporum f. sp. cubense tropical race 4 in soil. PLoS One 8:e82841.

Zheng, S.J., Garcia-Bastidas, F., Li, X., Zeng, L., Bai, T., Xu, S., Li, H., Fu, G., Yu, Y., Yang, L., Nguyen, HC., Dounneuang, D., Khaing, A., Drenth, A., Seidl, M., Meijer, H.J.G., and Kema, G.H.J. (2018) New Geographical Insights of the Latest Expansion of Fusarium oxysporum f.sp. cubense tropical race 4 Into the Greater Mekong Subregion. Frontiers in Plant Science. 


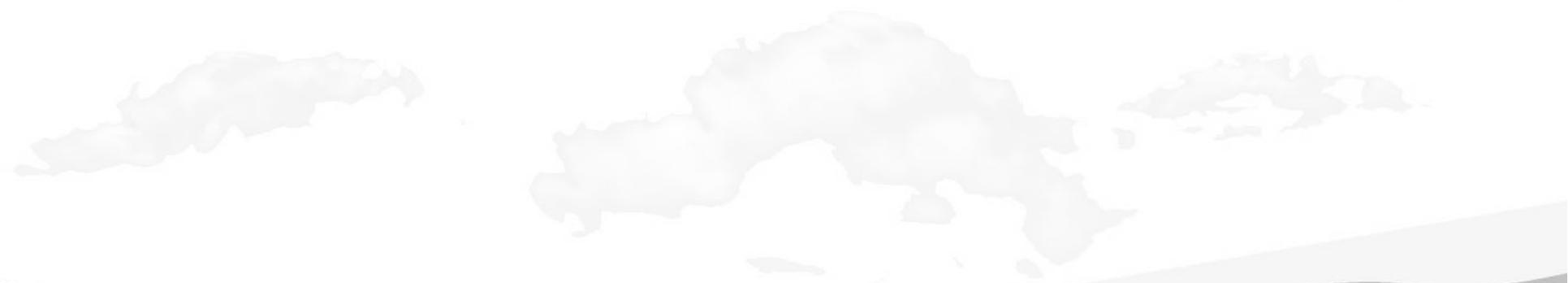

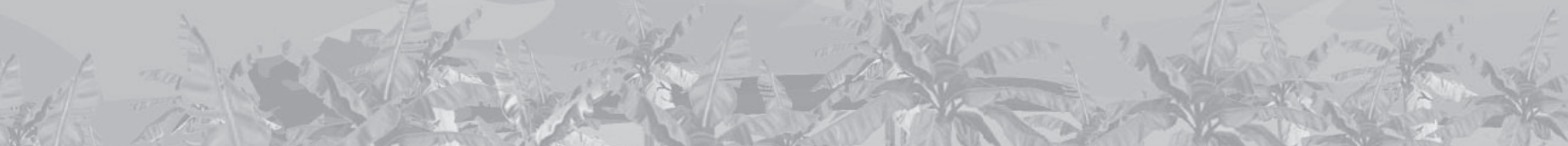

1.

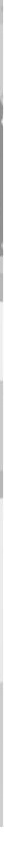




\section{CHAPTER 2}

\section{A Loop-Mediated Isothermal Amplification} assay based on unique markers derived from genotyping by sequencing data for rapid in-plant diagnosis of Tropical Race 4 in banana

\footnotetext{
Salacinas, M*., Ordóñez, N*., Mendes, O., Seidl, M.F., Meijer, H.J.G., Schoen, C.,
} and Kema, G.H.J.`(Accepted manuscript).

*These authors contributed equally to this work. 'Corresponding authors. 


\section{Abstract}

The socio-economic impact of Fusarium odoratissimum, which is colloquially called Tropical race 4 (TR4), is escalating as this fungal pathogen spreads to new banana-growing areas. Hence, the development of simple, reliable and rapid detection technologies is indispensable for implementing quarantine measures. Here, we develop a versatile LoopMediated Isothermal Amplification (LAMP) assay that is applicable under field and laboratory conditions. Unique DNA markers for TR4 were obtained by Diversity Arrays Technology sequencing (DArTseq), a genotyping by sequencing technology that was conducted on 27 genotypes comprising 24 previously reported vegetative compatibility groups (VCGs) of banana infecting Fusarium spp. and three TR4 isolates. The developed TR4 LAMP assay was successfully tested on 22 additional TR4 isolates and 45 non-target fungal and bacterial isolates as well as on infected plants under greenhouse and field conditions. The detection limit was $1 \mathrm{pg} / \mu \mathrm{l}$ pure TR4 DNA or $10^{2}$ copies of TR4 sequence (SeqA) in gBlock, which was not affected by background DNA in complex samples. The TR4 LAMP assay offers a powerful tool for the routine and unambiguous identification of infected banana plants, thereby contributing to advanced monitoring of Panama disease in field situations. 


\section{Introduction}

Soil-borne Fusarium spp. cause Fusarium wilt or Panama disease of bananas (Musa spp.), which currently poses a serious threat to global banana production (Ploetz, 2015b). These pathogens disseminate through transport of contaminated plants, human migration as well as infested soil and water (Ploetz, 2005, 2006). Panama disease has the historical legacy as one of the most destructive plant diseases recorded as it demised 'Gros Michel' banana plantations in Latin America, leading to the contemporary monocultures that heavily rely on resistant Cavendish bananas (Ploetz, 2015a; Ploetz et al., 2015a; Stover, 1962). Recent taxonomical evidence recognized the hitherto considered Fusarium oxysporum f.sp. cubense Race 1 strains that caused the previous epidemic as seven individual Fusarium spp. (Maryani et al., 2019). However, the current epidemic in Cavendish plantations as well as in manifold local banana varieties is caused by the so-called Tropical Race 4 (TR4) that belongs to the new species Fusarium odoratissimum and causes devastation in many producing areas (Maryani et al., 2019; García et al., 2019b; Ploetz, 2006, 2015a, 2015b). Contrary to the past, there is currently no commercially acceptable banana germplasm to replace Cavendish (Ploetz, 2015b) other than the widely promoted Cavendish somaclones that are less susceptible to TR4 (Hwang \& Ko, 2004). As a consequence, food security and local economies are threatened in banana producing countries.

TR4 was initially detected and restrained in a few Southeast Asian countries (Buddenhagen, 2009; Molina et al., 2009). However, this strain meanwhile spread to banana production areas in the Middle East, the Indian sub-continent, Africa and in Northeast Australia and continued its dissemination within Southeast Asia (Chittarath et al., 2017; García et al., 2014; Hung et al., 2017; Maymon et al., 2018; Mostert et al., 2017; O'Neill et al., 2016; Ordóñez et al., 2016; Ordóñez et al., 2015; Ploetz et al., 2015b; Thangavelu et al., 2019; Zheng et al., 2018). The spread might be a consequence of unawareness as well as to the fact that external Panama disease symptoms of bananas do not reveal the causal Fusarium spp.. Since Race 1 strains are omnipresent (Ploetz, 2015a), TR4 can easily slip in and unattendently affect Race 1 susceptible varieties until it affects Cavendish clones. Therefore, any suspicious wilting symptoms in Cavendish bananas should be properly and timely addressed, which should be followed by containment, precise sampling and rapid identification of the causal strains. Traditionally, TR4 diagnosis relied on visual disease inspections of internal and external symptoms of susceptible banana cultivars, and time-consuming vegetative compatibility group (VCG) testing. However, these methods are prone to false positives/negatives and in the case of VCG testing cause significant delays of TR4 diagnosis (García et al., 2014; Leslie \& Summerell, 2006; Molina et al., 2009). Considering that exclusion is the best approach to deal with TR4 and in the absence of long-term successful disease control (Ploetz, 2015b), early and reliable detection of TR4 is vital. In recent years, a DNA-based method succeeded in rapidly identifying TR4 in (pre) symptomatic banana plants (Dita et al., 2010). This PCRbased methodology was applied in all recent TR4 incursions (Chittarath et al., 2017; García et al., 2014; Hung et al., 2017; Ordóñez et al., 2016; Ploetz, 2015a; Zheng et al., 2018). However, it relies on the expertise and accuracy of individuals performing the diagnosis and 
equipment that is only used under laboratory conditions. Therefore, a robust and reliable molecular identification tool that is easily applicable in the field is desirable. The feasibility of developing molecular diagnostics depends largely on the availability of genome data for both target and non-target organisms. This allows the identification of unique genomic sequences, specific for the target organism. For the Fusarium genus, sequencing projects to reveal the genetic composition of various species started, but genomic data on the large diversity of individual genotpyes in these species is still limited (https://www.ncbi.nlm. nih.gov/genome/genomes/707). Despite the presumed exclusive asexual reproduction of Panama disease causing Fusarium spp., their polyphyletic origin resulted in no less than 24 VCGs (VCG0120-0126 and 0128-01224) (Bentley et al., 1998; Kistler et al., 1998; Ploetz, 2005), which includes VCG01213 that represents the TR4 clone (Ordóñez et al., 2015). The VCG01216 is genetically similar to VCG01213 and thus currently grouped under VCG01213 (Bentley et al., 1998).

In this study, we explored Diversity Arrays Technology sequencing (DArTseq) to identify unique genomic markers for TR4 to overcome the current lack of data among the previously mentiobed VCGs. DArTseq is an established high-throughput genotyping technology that is applied to address diversity analyses (Alves et al., 2014; Cruz et al., 2013). The technology combines a reduction of genome complexity with in silico- hybridization and next-generation sequencing platforms based on polymorphism detection at several hundreds of genomic loci that result in thousands of DArTseq in-silico markers and single nucleotide polymorphisms (Cruz et al., 2013). All 24 VCGs were subjected to DArTseq to select unique TR4 sequences. These genomic sequences were explored for primer design to develop a Loop-Mediated Isothermal Amplification (LAMP) assay, which is a cost-effective and robust technology that is suitable for detection of plant pathogens under field conditions (Bühlmann et al., 2013; Harper et al., 2010; Notomi et al., 2000; Tomlinson \& Boonham, 2015). Here, we validated the developed TR4 LAMP assay by performing specificity, sensitivity and reproducibility tests. Finally, we evaluated its accuracy by identifying TR4 infected banana plants in the field.

\section{Materials and methods}

\section{Microbial isolates}

In this study, 50 Fusarium isolates were used (Table 1), including one or more isolates per known VCG and 22 TR4 isolates including isolates from Jordan (García et al., 2014), Lebanon and Pakistan (Ordóñez et al., 2016), which were confirmed to belong to VCG01213 by VCG testing. In addition, 16 other Fusarium spp. were included in this study as well as Ralstonia solanacearum as a soil-borne banana wilting outgroup (Table 1). This strain was isolated from a Moko diseased Cavendish banana in the southern Philippines. All fungal isolates, grown from monosporic isolations are maintained in 15\% DMSO in liquid nitrogen in the collection of Wageningen University \& Research (WUR), The Netherlands. 
Table 1. The 22 TR4 target and 45 non-target fungal and bacterial isolates used in the development of the TR4 LAMP assay.

\begin{tabular}{|c|c|c|c|c|c|}
\hline Isolate code & Species & VCG & Host & Country & Provider \\
\hline \multicolumn{6}{|l|}{ Target-TR4 } \\
\hline 24662 & $\begin{array}{l}\text { Fusarium oxysporum f.sp. } \\
\text { cubense }\end{array}$ & $01213 / 16$ & Cavendish & Australia & A. Drenth, Australia \\
\hline 24663 & F. oxysporum f.sp. cubense & $01213 / 16$ & Cavendish & Australia & A. Drenth, Australia \\
\hline 24664 & F. oxysporum f.sp. cubense & $01213 / 16$ & Cavendish & Australia & A. Drenth, Australia \\
\hline BPS1.1 & F. oxysporum f.sp. cubense & 01213 & Cavendish & Indonesia & $\begin{array}{l}\text { I.W. Buddenhagen, } \\
\text { USA }\end{array}$ \\
\hline BPS3.1 & F. oxysporum f.sp. cubense & 01213 & Cavendish & Australia & $\begin{array}{l}\text { I.W. Buddenhagen, } \\
\text { USA }\end{array}$ \\
\hline Foc.T105 & F. oxysporum f.sp. cubense & 01213 & Cavendish & China & P.F.L. Chang, Taiwan \\
\hline $115^{1,2}$ & F. oxysporum f.sp. cubense & 01213 & Pisang Manurung & Indonesia & C. Kistler, USA \\
\hline Indo $84^{1}$ & F. oxysporum f.sp. cubense & 01216 & Williams & Indonesia & W. O'Neil, Australia \\
\hline Indo87 & F. oxysporum f.sp. cubense & $01213 / 16$ & Pisang Raja Serah & Indonesia & W. O'Neil, Australia \\
\hline $\mathrm{JV} 11^{1}$ & F. oxysporum f.sp. cubense & 01213 & Cavendish & Jordan & R.C. Ploetz, USA \\
\hline Leb1.1A & F. oxysporum f.sp. cubense & 01213 & Cavendish & Lebanon & $\begin{array}{l}\text { N. Ordóñez }{ }^{3} \text {, } \\
\text { Netherlands; M.Y. } \\
\text { Akkary, D. Freres, } \\
\text { Lebanon }\end{array}$ \\
\hline Leb1.2C & F. oxysporum f.sp. cubense & 01213 & Cavendish & Lebanon & $\begin{array}{l}\text { N. Ordóñez } \\
\text { Netherlands; M.Y. } \\
\text { Akkary, D. Freres, } \\
\text { Lebanon }\end{array}$ \\
\hline Mal123 & F. oxysporum f.sp. cubense & 01213 & Williams & Malaysia & W. O'Neil, Australia \\
\hline NRRL36114 & F. oxysporum f.sp. cubense & 01213 & Pisang Manurung & Indonesia & K. O'Donnell, USA \\
\hline Pak1.1A & F. oxysporum f.sp. cubense & 01213 & Cavendish & Pakistan & $\begin{array}{l}\text { N. Ordóñez }{ }^{3}, \\
\text { Netherlands; H.B. } \\
\text { Laghari, Pakistan }\end{array}$ \\
\hline Phi1.1A & F. oxysporum f.sp. cubense & 01213 & Williams & Philippines & $\begin{array}{l}\text { N. Ordóñez } \\
\text { Netherlands; L.M. } \\
\text { Bacus, Philippines }\end{array}$ \\
\hline Phi2.5C & F. oxysporum f.sp. cubense & 01213 & GCTVC218 & Philippines & $\begin{array}{l}\text { N. Ordóñez } \\
\text { Netherlands; L.M. } \\
\text { Bacus, Philippines }\end{array}$ \\
\hline Phi3.4C & F. oxysporum f.sp. cubense & 01213 & Williams & Philippines & $\begin{array}{l}\text { N. Ordóñez } \\
\text { Netherlands; A.F. } \\
\text { Penalosa, L.M. } \\
\text { Bacus, Philippines }\end{array}$ \\
\hline Phi4.5A & F. oxysporum f.sp. cubense & 01213 & UNIC4 & Philippines & $\begin{array}{l}\text { N. Ordóñez } \\
\text { Netherlands; A.F. } \\
\text { Penalosa, L.M. } \\
\text { Bacus, Philippines }\end{array}$ \\
\hline Phi5.2A & F. oxysporum f.sp. cubense & 01213 & Grand Naine & Philippines & $\begin{array}{l}\text { N. Ordóñez } \\
\text { Netherlands }\end{array}$ \\
\hline RPML47 & F. oxysporum f.sp. cubense & $01213 / 16$ & Pisang awak legor & Malaysia & R.C. Ploetz, USA \\
\hline STSUM2 & F. oxysporum f.sp. cubense & 01213 & Pisang Kepok & Indonesia & R.C. Ploetz, USA \\
\hline
\end{tabular}




\begin{tabular}{|c|c|c|c|c|c|}
\hline Isolate code & Species & VCG & Host & Country & Provider \\
\hline \multicolumn{6}{|c|}{ Non-target isolates } \\
\hline FocST498 $^{1}$ & F. oxysporum f.sp. cubense & 0120 & Dwarf Cavendish & Spain & J. Hernandez, Spain \\
\hline NRRL25603 & F. oxysporum f.sp. cubense & $0120 / 15$ & Cavendish & Australia & K. O'Donnell, USA \\
\hline NRRL36102 ${ }^{1}$ & F. oxysporum f.sp. cubense & 0121 & Cavendish & China & K. O'Donnell, USA \\
\hline NRRL36103 ${ }^{1}$ & F. oxysporum f.sp. cubense & 0122 & Cavendish & Philippines & K. O'Donnell, USA \\
\hline F91291 & F. oxysporum f.sp. cubense & 0123 & Latundan & China & R.C. Ploetz, USA \\
\hline NRRL36105 & F. oxysporum f.sp. cubense & 0124 & Blugoe & Honduras & K. O'Donnell, USA \\
\hline Foc_R2 ${ }^{1}$ & F. oxysporum f.sp. cubense & 0124 & Plantain Monthan & Brazil & $\begin{array}{l}\text { M.A. Dita, } \\
\text { EMBRAPA, Brazil }\end{array}$ \\
\hline NRRL36106 ${ }^{1}$ & F. oxysporum f.sp. cubense & 0125 & Lady finger & Australia & K. O'Donnell, USA \\
\hline NRRL36107 ${ }^{1}$ & F. oxysporum f.sp. cubense & 0126 & Maqueño & Honduras & K. O'Donnell, USA \\
\hline NRRL36111 & F. oxysporum f.sp. cubense & 0128 & Bluggoe & Australia & K. O'Donnell, USA \\
\hline NRRL36110 & F. oxysporum f.sp. cubense & 0129 & Mons & Australia & K. O'Donnell, USA \\
\hline Focu $7^{1}$ & F. oxysporum f.sp. cubense & 01210 & Apple & USA & $\begin{array}{l}\text { M.J. Daboussi, } \\
\text { Université Paris - } \\
\text { Sud, France }\end{array}$ \\
\hline NRRL36109¹ & F. oxysporum f.sp. cubense & 01211 & SH3142 & Australia & K. O'Donnell, USA \\
\hline NRRL36108 ${ }^{1}$ & F. oxysporum f.sp. cubense & 01212 & Ney Poovan & Tanzania & K. O'Donnell, USA \\
\hline NRRL36113 ${ }^{1}$ & F. oxysporum f.sp. cubense & 01214 & Harare & Malawi & K. O'Donnell, USA \\
\hline NRRL25609 & F. oxysporum f.sp. cubense & 01214 & Harare & Malawi & K. O'Donnell, USA \\
\hline NRRL36112 ${ }^{1}$ & F. oxysporum f.sp. cubense & 01215 & Cavendish & South Africa & K. O'Donnell, USA \\
\hline Mal43 ${ }^{1}$ & F. oxysporum f.sp. cubense & 01217 & Pisang Rastali & Malaysia & A. Drenth, Australia \\
\hline NRRL361201 & F. oxysporum f.sp. cubense & 01218 & Kluai nam wa & Thailand & K. O'Donnell, USA \\
\hline Indo $25^{1}$ & F. oxysporum f.sp. cubense & 01219 & Pisang Ambon & Indonesia & A. Drenth, Australia \\
\hline 242181 & F. oxysporum f.sp. cubense & 01220 & Cavendish & Australia & A. Drenth, Australia \\
\hline NRRL36118 ${ }^{1}$ & F. oxysporum f.sp. cubense & 01221 & Kluai nam wa & Thailand & K. O'Donnell, USA \\
\hline NRRL36117 ${ }^{1}$ & F. oxysporum f.sp. cubense & 01222 & Pisang awak legor & Malaysia & K. O'Donnell, USA \\
\hline NRRL36116 & F. oxysporum f.sp. cubense & 01223 & Pisang keeling & Malaysia & K. O'Donnell, USA \\
\hline NRRL36115 & F. oxysporum f.sp. cubense & 01224 & Pisang ambon & Malaysia & K. O'Donnell, USA \\
\hline Foc_R $1^{1}$ & F. oxysporum f.sp. cubense & n.d. & Maçã & Brazil & $\begin{array}{l}\text { M. Dita, C. Waalwijk, } \\
\text { Netherlands }\end{array}$ \\
\hline KDM1.2A & F. oxysporum f.sp. cubense & n.d. & Bokoboko & Kenya & $\begin{array}{l}\text { N. Ordóñez }{ }^{3} \text {, } \\
\text { Netherlands; C.M. } \\
\text { Muriuki, Del Monte, } \\
\text { Kenya }\end{array}$ \\
\hline Mal1.5B & F. oxysporum f.sp. cubense & n.d. & $\begin{array}{l}\text { Banana (Musa } \\
\text { sp.) }\end{array}$ & Malawi & $\begin{array}{l}\text { G. Kema, N. } \\
\text { Ordóñez }{ }^{3} \text {, } \\
\text { Netherlands }\end{array}$ \\
\hline 0.1879 & $\begin{array}{l}\text { F. oxysporum f.sp. } \\
\text { melongenae }\end{array}$ & n.d. & Eggplant & n.d. & $\begin{array}{l}\text { C. Waalwijk, } \\
\text { Netherlands }\end{array}$ \\
\hline $0.1954^{1}$ & $\begin{array}{l}\text { F. oxysporum f.sp. } \\
\text { canariensis }\end{array}$ & n.d. & Palm & n.d. & $\begin{array}{l}\text { C. Waalwijk, } \\
\text { Netherlands }\end{array}$ \\
\hline CBS196.65 & F. oxysporum f.sp. narcissi & n.d. & Narcissus & n.d. & $\begin{array}{l}\text { C. Waalwijk, } \\
\text { Netherlands }\end{array}$ \\
\hline
\end{tabular}




\begin{tabular}{|c|c|c|c|c|c|}
\hline Isolate code & Species & VCG & Host & Country & Provider \\
\hline Fo47 & F. oxysporum & n.d. & Non-pathogenic & n.d. & $\begin{array}{l}\text { C. Waalwijk, } \\
\text { Netherlands }\end{array}$ \\
\hline Fol4287 & $\begin{array}{l}\text { F. oxysporum f.sp. } \\
\text { lycopersici }\end{array}$ & n.d. & Tomato & n.d. & $\begin{array}{l}\text { S.M. Schmidt, } \\
\text { Netherlands }\end{array}$ \\
\hline Fop.08.1 & F. oxysporum f.sp. passiflora & n.d. & Passion fruit & n.d. & $\begin{array}{l}\text { C. Waalwijk, } \\
\text { Netherlands }\end{array}$ \\
\hline NRRL25433 & $\begin{array}{l}\text { F. oxysporum f.sp. } \\
\text { vasinfectum }\end{array}$ & n.d. & Cotton & n.d. & $\begin{array}{l}\text { S.M. Schmidt, } \\
\text { Netherlands }\end{array}$ \\
\hline $\begin{array}{l}\text { NRRL26035/ } \\
\text { IP099.03 }\end{array}$ & $\begin{array}{l}\text { F. oxysporum f.sp. } \\
\text { canariensis }\end{array}$ & n.d. & Palm & n.d. & $\begin{array}{l}\text { C. Waalwijk, } \\
\text { Netherlands }\end{array}$ \\
\hline $\begin{array}{l}\text { NRRL26381/ } \\
\text { CL57 }\end{array}$ & $\begin{array}{l}\text { F. oxysporum f.sp. radicis- } \\
\text { lycopersici }\end{array}$ & n.d. & Tomato & n.d. & $\begin{array}{l}\text { S.M. Schmidt, } \\
\text { Netherlands }\end{array}$ \\
\hline $\begin{array}{l}\text { NRRL26406/ } \\
\text { Fom001 }\end{array}$ & F. oxysporum f.sp. melonis & n.d. & Melon & n.d. & $\begin{array}{l}\text { S.M. Schmidt, } \\
\text { Netherlands }\end{array}$ \\
\hline $\begin{array}{l}\text { NRRL26761/ } \\
\text { IP099.04 }\end{array}$ & F. oxysporum f.sp. phaseoli & n.d. & Bean & n.d. & $\begin{array}{l}\text { C. Waalwijk, } \\
\text { Netherlands }\end{array}$ \\
\hline $\begin{array}{l}\text { NRRL28781/ } \\
\text { IP099.02 }\end{array}$ & $\begin{array}{l}\text { F. oxysporum f.sp. } \\
\text { erythroxyli }\end{array}$ & n.d. & Coca & n.d. & $\begin{array}{l}\text { C. Waalwijk, } \\
\text { Netherlands }\end{array}$ \\
\hline $\begin{array}{l}\text { NRRL37622/ } \\
\text { HDV247 }\end{array}$ & F. oxysporum f.sp. pisi & n.d. & Pea & n.d. & $\begin{array}{l}\text { S.M. Schmidt, } \\
\text { Netherlands }\end{array}$ \\
\hline $\begin{array}{l}\text { NRRL54005/ } \\
\text { PHW815 }\end{array}$ & F. oxysporum f.sp. raphani & n.d. & Radish & n.d. & $\begin{array}{l}\text { S.M. Schmidt, } \\
\text { Netherlands }\end{array}$ \\
\hline $\begin{array}{l}\text { NRRL54008/ } \\
\text { PHW808 }\end{array}$ & $\begin{array}{l}\text { F. oxysporum f.sp. } \\
\text { conglutinans }\end{array}$ & n.d. & Cabbage & n.d. & $\begin{array}{l}\text { S.M. Schmidt, } \\
\text { Netherlands }\end{array}$ \\
\hline CBS221.76 & Fusarium fujikuroi & n.a. & Rice & n.d. & $\begin{array}{l}\text { C. Waalwijk, } \\
\text { Netherlands }\end{array}$ \\
\hline Moko & Ralstonia solanacearum & n.a. & $\begin{array}{l}\text { Banana (Musa } \\
\text { sp.) }\end{array}$ & n.d. & $\begin{array}{l}\text { M. Salacinas, } \\
\text { Netherlands }\end{array}$ \\
\hline
\end{tabular}

${ }^{1}$ Fungal isolates analysed using DArTseq. ${ }^{2}$ TR4 reference isolate. ${ }^{3}$ Providers sent tissue sample to our facilities and the strain isolation was performed at Wageningen University \& Research. n.a. stands for "not applicable". n.d. stands for "not determined".

\section{DNA extraction from fungal and bacterial isolates}

For DNA extraction, a single-spore culture of each isolate was grown in $70 \mathrm{~mL}$ potato dextrose broth (Difco ${ }^{\mathrm{TM}}$, USA) in Erlenmeyer flasks and incubated by shaking (New Brunswick $^{\mathrm{TM}}$, Germany) at $125 \mathrm{rpm}$ at $25^{\circ} \mathrm{C}$ for 5-6 days. The mycelium was harvested by filtering the inoculum through a sterile cheese cloth and washed at least twice with sterile water. R. solanacearum was grown on Kelman's tetrazolium chloride agar (Kelman, 1954). The filtered mycelium and $1 \mathrm{~mL}$ bacterial suspension were lyophilized in $2 \mathrm{~mL}$ Eppendorf tubes containing glass beads. DNA was extracted from the freeze-dried material by adding $1 \mathrm{~mL}$ DNA extraction buffer (200 mM Tris-HCl, pH 8; 250 mM NaCl; 25 mM EDTA, pH 8; 0.5\% SDS) and a vigorous vortex step, followed by phenol-chloroform extraction (Sambrook et al., 1989). Isolated DNA was diluted in 0.1X TE buffer and stored at $-20^{\circ} \mathrm{C}$ until use. DNA concentration was measured using Quant-i $\mathrm{T}^{\mathrm{TM}}$ PicoGreen $^{\circledR}$ dsDNA Reagent and Kit (Life 
Technologies, USA), according to manufacturer's instructions on a Tecan Infinite ${ }^{\circledR} 200$ PRO monochromator (Tecan, Männedorf, Switzerland) at $\lambda$ ex $485 \mathrm{~nm}$ and $\lambda e m 535 \mathrm{~nm}$. DNA of 27 samples comprising 23 VCGs and three TR4 isolates (II5, JV11 and Indo84), and one F. oxysporum f.sp. canariensis isolate (Table 1) was adjusted to $50 \mathrm{ng} / \mu \mathrm{l}$ and subjected to genotyping by sequencing through DArTseq analyses at Diversity Arrays Technology Pty Ltd. (Canberra, Australia; http://www.triticarte.com.au/).

\section{Pipeline based on DArTseq in-silico markers}

The DArTseq in-silico markers consisted of short markers of around $69 \mathrm{bp}$ that were processed following the pipeline indicated in Figure 1. This pipeline includes the use of public and private genomic databases. The NCBI public database comprises nucleotide information for different Fusarium spp. (http://www.ncbi.nlm.nih.gov/genome/genomes/707). The Empresa Brasileira de Pesquisa Agropecuária (Embrapa) private database (http://www.lba. cnptia.embrapa.br/fusarium/index.tml; Embrapa, Brasilia, Brazil) contains transcriptome data from race 1 (R1), race 2 (R2; VCG0124), subtropical race 4 (ST498; VCG0120) and TR4 (II5; VCG01213) isolates (Table 1). Firstly, DArTseq in-silico markers that were only present among the three TR4 isolates (II5, JV11 and Indo84) but absent from the other strains were selected (Figure 1 step 1). Then, TR4 unique markers that aligned only with the II5 (isolate 54006) genome at NCBI when using the basic local alignment search tool (BLAST) were selected (Figure 1 steps 2-3). Later, these short markers were subsequently expanded using the 115 genome by more than $200 \mathrm{bp}$ up- and downstream (Figure 1 step 4). These larger sequences ( $500 \mathrm{bp}$ ) were blasted against genomic data present in both databases and sequences aligning with the 115 genome were used for further analyses (Figure 1 steps 5-6).

\section{PCR conditions to select TR4 unique sequences}

Identified unique DArTseq-based TR4 sequences (Figure 1 step 6) were further analysed by designing PCR primers at their flanking sequences using software Primer3Plus (Version: 2.3.6). The designed primers were initially tested for all reported 24 VCGs with II5 isolate as a representative of VCG01213. PCR amplifications were performed in $20 \mu \mathrm{l}$ reaction volumes, by mixing $1 \mu \mathrm{l}$ template DNA (1 ng) with $0.4 \mu \mathrm{M}$ of each primer: $120 \mu \mathrm{M}$ of dATP, dCTP, dGTP and dTTP; $2 U$ of Taq DNA polymerase (Roche); and $1 X$ PCR reaction buffer (Roche). DNA was amplified with an initial denaturation step at $95^{\circ} \mathrm{C}$ for 5 minutes ( $\mathrm{min}$ ), followed by 30 cycles of $95^{\circ} \mathrm{C}$ for $1 \mathrm{~min}$, annealing temperature for $1 \mathrm{~min}$ and $72^{\circ} \mathrm{C}$ for 30 seconds (s); and a final extension step at $72{ }^{\circ} \mathrm{C}$ for $10 \mathrm{~min}$. The annealing temperature was determined by Primer3Plus (Untergasser et al., 2007; Version: 2.3.6) for each tested pair of primers. Aliquots $(12 \mu \mathrm{l})$ of each PCR product were analysed by agarose gel electrophoresis to check for predicted size products. A primer set that showed a unique band for II5 isolate was selected and later tested on 22 TR4 isolates (Table 1), using the same PCR conditions. The resulting amplicons were sequenced by Macrogen (Macrogen Inc., Belgium) and analysed using CLC Main Workbench 6 program (CLC bio, Aarhus, Denmark). 


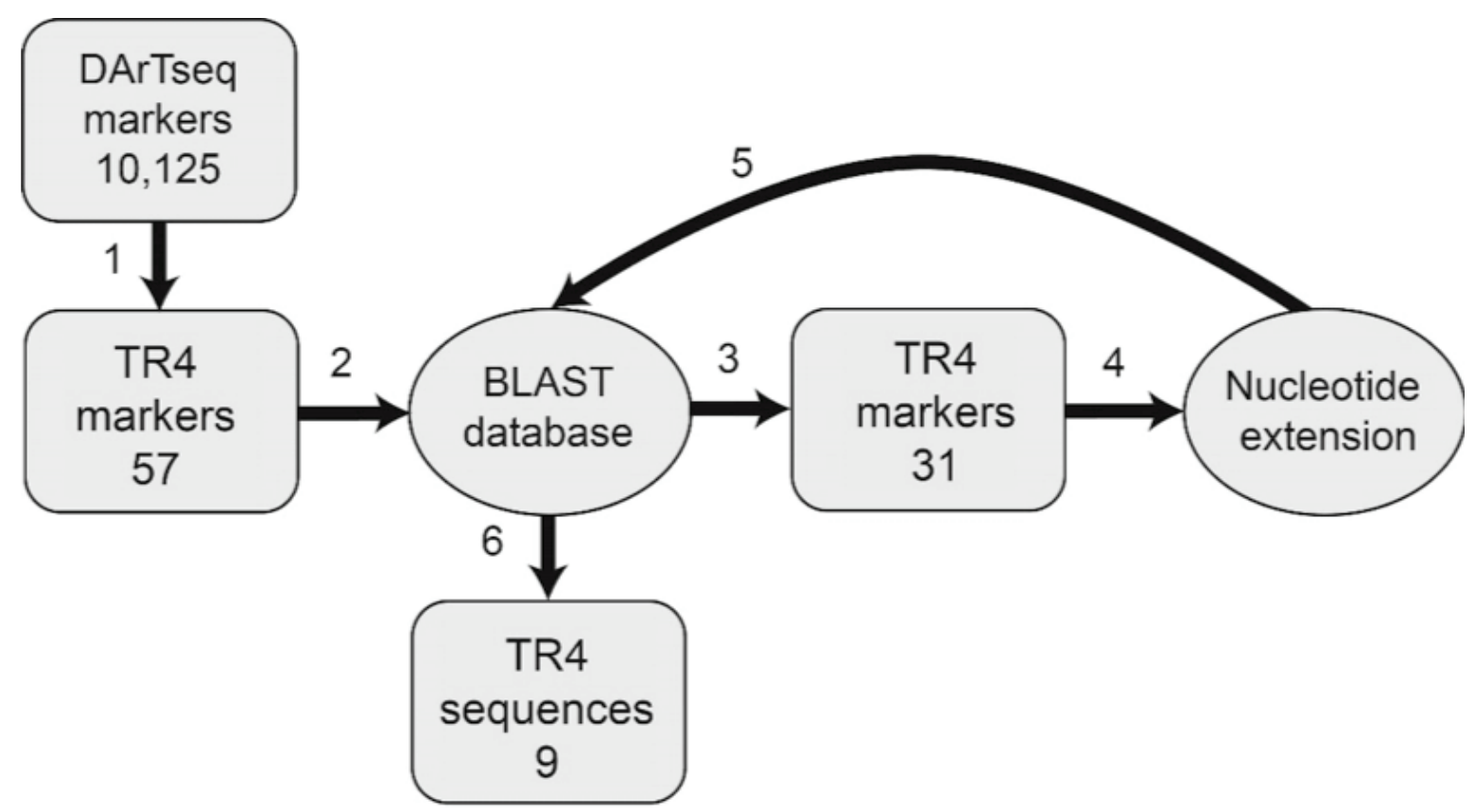

Figure 1. Pipeline used to identify unique TR4 sequences based on DArTseq in-silico markers. Numbers next to arrows indicate the order of the steps involved in the selection process.

\section{LAMP TR4 primer design and reaction}

For a selected unique TR4 sequence (SeqA), LAMP primers were designed using software Primer Explorer V4 (http://primerexplorer.jp/e/; Eiken Chemical Co. Ltd., Tokyo, Japan) (Figure 2 and Table 2). LAMP primers consist of four to six primers that recognize six to eight regions of the target DNA and provides very high specificity (Nagamine et al., 2002; Notomi et al., 2000). The forward inner primer (FIP) is composed of F1c (the complementary sequence of F1) and F2, and the backward inner primer (BIP) is composed of B1c (the complementary sequence of B1) and B2. The primer set F3/B3 served as an outer primer and was used for the LAMP initiation reaction. The LoopF forward primers and the LoopB backward primers were developed to accelerate the LAMP reaction. The specificity of the developed LAMP TR4 primers was checked in-silico using BLAST at NCBI against other fungi and plant sequences. The TR4 LAMP reaction was performed according to the instructions of the Isothermal Master Mix ISO-001 kit (Optigene Limited, UK). Reactions were performed in a final volume of $25 \mu \mathrm{L}$ consisting of $15 \mu$ l Master Mix ISO-001, $2 \mu \mathrm{l}$ primer mix $(0.8 \mu \mathrm{M}$ of each FIP and BIP primer, $0.2 \mu \mathrm{M}$ of each F3 and B3 primer, and $0.4 \mu \mathrm{M}$ of each LF and LB primers), $1 \mathrm{ng}$ of template DNA and nuclease-free water. The reactions were carried out at $65^{\circ} \mathrm{C}$ for $30 \mathrm{~min}$. followed by an annealing step ramping at $0.5^{\circ} \mathrm{C} / \mathrm{s}$ from $98^{\circ} \mathrm{C}$ to $80^{\circ} \mathrm{C}$. For each LAMP reaction, TR4 (II5) DNA was used as a positive control and nuclease-free water as negative control. All LAMP reactions were run in the Genie II instrument (Optigene Ltd., UK) that allows 16 simultaneous reactions. The criteria for positive signals were based on two parameters: Time of positivity (Tp) stated in min. and melting temperature ( $T m$ ) stated in ${ }^{\circ} \mathrm{C}$. The $\mathrm{Tp}$ is calculated as the time at which the maximum increase of fluorescence is 
reached. The Tm is the temperature at which half of the LAMP products are in the singlestranded state. This temperature is specific and unique for each LAMP product and allows discrimination for unspecific amplification.

Table 2. LAMP primers designed in this study.

\begin{tabular}{|c|c|c|}
\hline Target & LAMP Primers & 5'- 3' primer sequence \\
\hline \multirow[t]{6}{*}{ TR4 (VCG01213) } & SeqA_F3 & AATAGTAAAGATGCTGAACTTCT \\
\hline & SeqA_B3 & ACTCTTGTGAGAGGTCGA \\
\hline & SeqA_FIP & TGGGAGGAAGAACTTTCTAGTAT-GAGAAAGGATAAGGGATGTAATGTTG \\
\hline & SeqA_BIP & TTGCTCAATTTCCTTGTGTTTCG-CAGGATTCACGATAGTAGAGTT \\
\hline & SeqA_Loop F & ACCAAAAGCCTAGGAGAGGATT \\
\hline & SeqA_Loop B & TCTTCTTCTTCGCCGTACCTCATCA \\
\hline \multirow{6}{*}{$\begin{array}{l}\text { Banana cox gene } \\
\text { (Musa spp.) }\end{array}$} & MusaCox_F3 & GCCTGGATCCGGTATCATA \\
\hline & MusaCox_B3 & TTGAATTGTATCGAACCTCCC \\
\hline & MusaCox_FIP & CGTATCAACGTCTAAGCCCACATGCCATGATCAGTATAGGTGT \\
\hline & MusaCox_BIP & TGCCTACTTCACCGCTGCCACATAGTAGCGATCCAACTAA \\
\hline & MusaCox_Loop F & GATGAGCCCAAACAAGAAATCC \\
\hline & MusaCox_Loop B & CCATGATCATAGCTGTCCCTAC \\
\hline
\end{tabular}

\section{Specificity, sensitivity and reproducibility tests}

The developed TR4 LAMP assay was tested for specificity, sensitivity and reproducibility following the reaction conditions described above in order to validate its efficiency in detecting pure TR4 DNA samples. The specificity of the assay was evaluated using 22 target TR4 DNAs and 45 non-target fungal and bacterial DNAs (Table 1). The sensitivity test was run twice using a dilution series of $1000,100,10,1,0.1$ and $0.01 \mathrm{pg} / \mu \mathrm{l}$ of pure TR4 (II5) DNA. The dilution series was tested in the presence and absence of pure DNA ( $1 \mathrm{ng} / \mu \mathrm{l})$ from 'Grand Naine' banana cultivar. Additionally, plasmid DNA containing selected $\sim 500 \mathrm{bp}$ sequence (SeqA) was synthesized (IDT, Belgium) to further determine the sensitivity of the developed assay. Picogreen quantified plasmid DNA was diluted from $10^{9}$ to $10^{\circ}$ copies $/ \mu$. Finally for the reproducibility test, the TR4 LAMP assay was repeated five times using $1 \mu$ l of TR4 (II5) DNA (1 ng) as a positive control and Race 1 DNA (1 ng) and nuclease-free water as negative controls.

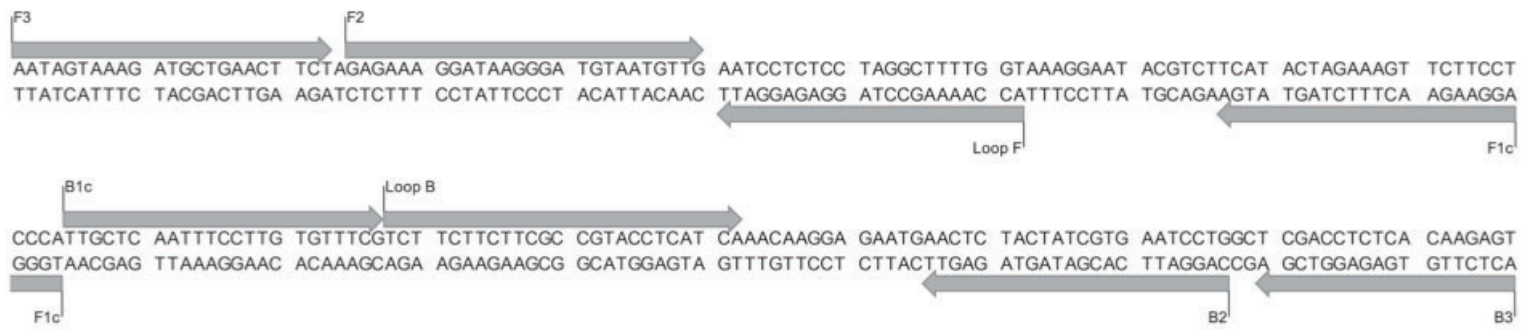

Figure2. UniqueTR4 sequence(SeqA) showing thelocation of developed LAMPTR4 primers: F3, B3, FIP(F1C-F2), BIP (B1C-B2), Loop Fand B. The arrows indicate the 5' to 3' direction of extension. 


\section{Testing the TR4 LAMP assay for in-plant diagnosis}

A simple, rapid and inexpensive procedure was developed to quickly release DNA from plant tissue for TR4 detection with a minimum of equipment. Firstly, plant tissue was cut into small cubes and placed in a $5 \mathrm{ml}$ extraction tube containing one steel ball (Optigene Limited, UK) and $1 \mathrm{ml}$ epicentre buffer (Quick Extract RNA extraction solution) with Chelex100 resin. The tube was vigorously shaken by hand for $1 \mathrm{~min}$ to homogenize the solution and incubated at $95^{\circ} \mathrm{C}$ in a water bath for $20 \mathrm{~min}$. After short mixing, the solution was left at room temperature for $1 \mathrm{~min}$. Finally, it was diluted 15 times using Optigene dilution buffer (Optigene Limited, UK) and $5 \mu$ of this solution was added to the LAMP TR4 reaction vial. Feasibility trials with the TR4 LAMP assay were conducted on 'Grand Naine' plants artificially (WUR greenhouse, The Netherlands) and naturally infected (Mindanao, The Philippines) with TR4. At WUR two months old plants were inoculated with $10^{6}$ conidia/ml TR4 (II5) inoculum following the protocol developed by García et al. (2019a). Water inoculated plants were used as negative control. Rhizome tissue was recovered eight weeks after inoculation (wai) and stored at $-20^{\circ} \mathrm{C}$ until use. In The Philippines, the TR4 LAMP assay was tested using rhizome and pseudostem tissue of 'Grand Naine' plants collected from a naturally infested (north: $7^{\circ} 31^{\prime} 21^{\prime \prime}$ east: $125^{\circ} 40^{\prime} 17^{\prime \prime}$ ) and a disease-free (north: $7^{\circ} 32^{\prime} 17^{\prime \prime}$ east: $125^{\circ} 39^{\prime} 44^{\prime \prime}$ ) banana plantation in Davao del Norte. All plant samples were tested in parallel with the LAMP MusaCox assay as an extraction and internal control. The LAMP banana primers (Table 2) were designed on the dwarf banana (Musa acuminata) mitochondrial cytochrome oxidase (cox1) gene exons 1-2 (AJ247609 at NCBI) using software Primer Explorer V4 (http://primerexplorer.jp/e/; Eiken Chemical Co. Ltd., Tokyo, Japan). This primer set gave a positive signal for DNA obtained from 'Grand Naine' and many other banana cultivars (data not shown). The reaction conditions of the LAMP MusaCox assay were the same as described for TR4 LAMP assay. To test the robustness of the developed LAMP assays for in-plant diagnosis, we performed the simple procedure to obtain DNA as described above two to three times for each evaluated tissue sample. The obtained solutions were run twice following the conditions of our developed TR4 LAMP assay.

\section{Results}

\section{DArTseq pipeline outputs}

From an initial DArTseq platform containing 15,905 DArTseq in-silico markers, 10,125 high quality markers were obtained that passed the stringent quality criteria (call rate $>0.66$, reproducibility $=100$ and $Q$ value $>2.7$ ). Following the selection pipeline (Figure 1), we acquired 57 TR4 unique markers based on the three chosen isolates (II5, JV11 and Indo84) (Figure 1 step 1; Figure 3). BLAST analysis reduced this to 31 unique markers that blasted to the TR4 II5 reference genome (Figure 1 steps 2-3). Subsequently, the marker borders were expanded ( $\sim 500 \mathrm{bp}$ ) using the II5 genome. Finally, nine sequences remained TR4 unique when blasted against fungal genomes from both databases (Figure 1 steps 4-6). 


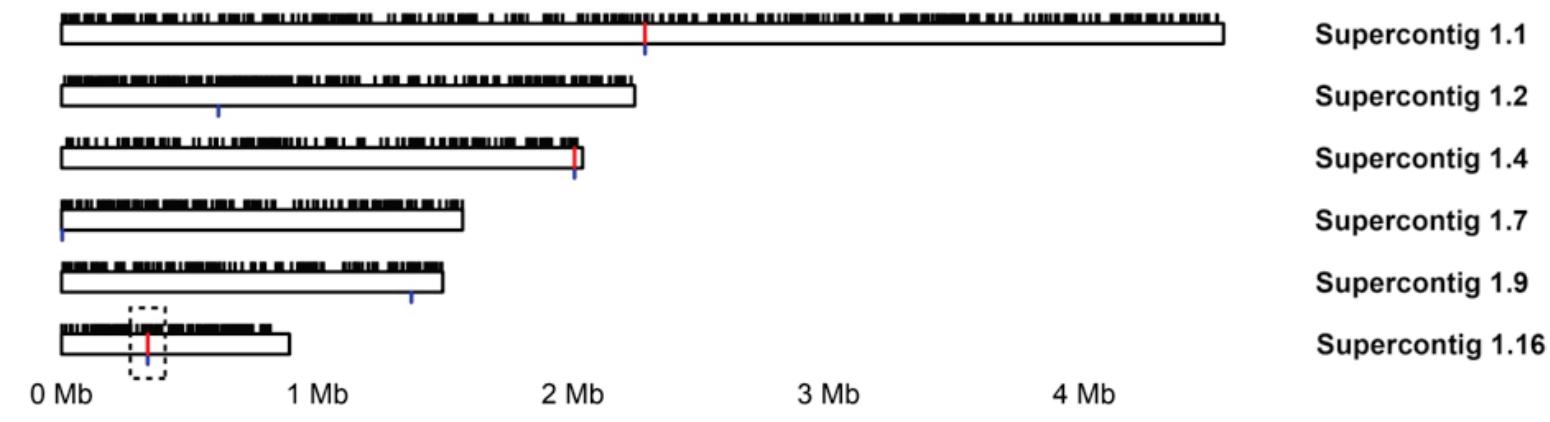

Figure 3. Distribution of the 10,125 DArTseq in-silico markers along the largest contigs of the Fusarium odoratissimum TR4 II5 genome available at NCBI are shown in balck, while some of the 31 markers present only within TR4 isolates after blasting on the genome databases are shown in blue and nine remained unique markers after extenstion are shown in red. The location of SeqA TR4 sequence is highlighted on Supercontig 1.16.

\section{PCR selection of a TR4 unique sequence}

To choose among the nine TR4 sequences, primer sets linked to these nine sequences were validated on 24 Fusarium genotypes. In most cases, the primer sets specifically amplified a unique band for the II5 isolate (VCG01213) but not for the other Fusarium genotypes (Figure 4). Primers set (SeqA) was selected and tested on 22 TR4 isolates, generating a product with the same band size. These amplicons were sequenced, revealing that all nucleotide sequences were identical (data not shown). Thus, the proposed pipeline (Figure 1) and further PCR analyses established the identification of a TR4 unique sequence of around $>500$ bp corresponding to supercont1.16 (336895-337463+), on which LAMP primers were designed. This sequence was confirmed to be single copy, non-coding and non-repetitive based on the annotated II5 genome, availableathttp://www.broadinstitute.org/annotation/ genome/fusarium_group/FeatureSearch.html).

\section{Specificity, sensitivity and reproducibility tests}

To assess for specificity, the TR4 LAMP assay was tested on known TR4 isolates as well as on other Fusarium spp. and non-banana Fusarium spp. strains. In all cases, the TR4 isolates yielded a positive signal; while all non-targets, including the other Fusarium spp. genotypes tested negative. We expanded the LAMP analysis by including the previously published TR4 LAMP assay following their suggested reaction conditions (Zhang et al., 2013). For the tested Fusarium spp. panel, this TR4 LAMP assay, however, resulted in positive signals to Fusarium spp. isolates other than TR4, suggesting that they are not TR4 specific (Table 3 and sTable 1). LAMP assays should be highly sensitive in order to detect DNA from plant tissues. The LAMP sensitivity test shows that our TR4 LAMP assay can detect up to $1 \mathrm{pg} / \mu \mathrm{l}$ pure TR4 DNA ( $T p=14: 52 \mathrm{~min}$ and $\mathrm{Tm}=83.4^{\circ} \mathrm{C}$ ). It is not prone to the presence of irrelevant DNA since the presence or absence of $1 \mathrm{ng} / \mu \mathrm{l}$ background banana DNA neither affected the amplification efficiency nor generated background signals. The sensitivity was evaluated by adding plasmid DNA containing the SeqA sequence. Our LAMP assay was found to be very 
sensitive and able to generate an amplicon with a detection limit of $10^{2}$ copies (average $\mathrm{Tp}=15: 20 \mathrm{~min}$ and $\mathrm{Tm}=83.4^{\circ} \mathrm{C}$; Figure 5 ). The robustness of our LAMP TR4 was shown by producing consistent results with the presence of $1 \mathrm{ng}$ pure TR4 DNA (II5) per reaction (average $\mathrm{Tp}=13: 40 \mathrm{~min}$ and $\mathrm{Tm}=83.4^{\circ} \mathrm{C}$ ). For the negative control samples (Foc_R1 and nuclease-free water), no Tp or Tm was obtained.

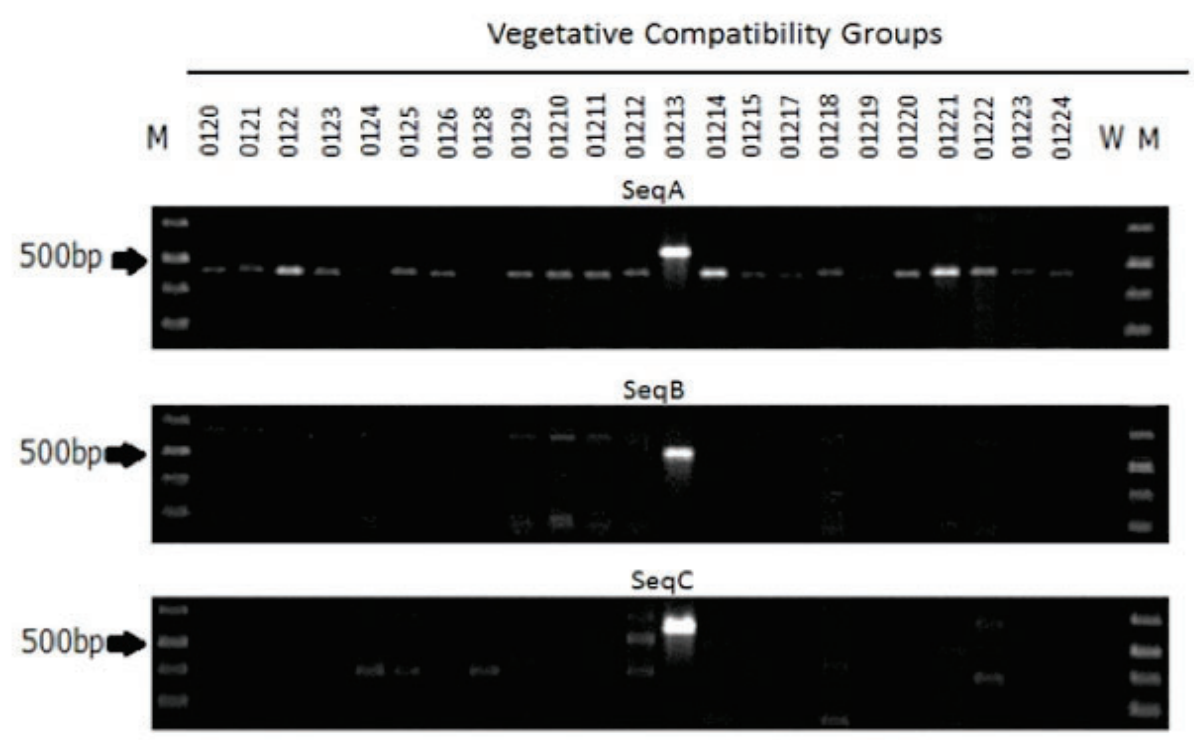

Figure 4. TR4 amplicons ( $500 \mathrm{bp}$ each) from three unique TR4 sequences (from top to bottom: SeqA, SeqB and SeqC). The PCR primer sets were tested against all previously reported Fo VCGs. M stands for "molecular marker". W stands for "Water".

Table 3. Specificity comparison of previously published LAMP TR4 primers (Zhang et al., 2013) and the newly developed LAMP TR4 primers on a set of TR4 isolates, and non-target Fusarium spp. and other fungal and bacterial strains.

\begin{tabular}{lll}
\hline Isolates $^{1}$ & $\begin{array}{l}\text { LAMP TR4 } \\
\text { this study }\end{array}$ & $\begin{array}{l}\text { LAMP TR4 } \\
\text { (Zhang } \text { et al., 2013) }\end{array}$ \\
\hline TR4 (VCG01213) & $22 / 22$ & $2 / 2^{2}$ \\
\hline All other Foc VCGs & $0 / 28$ & $22 / 22^{3}$ \\
\hline Non - Foc & $0 / 17$ & Not tested \\
\hline
\end{tabular}

${ }^{1}$ Isolates listed in Table $1 .{ }^{2}$ Isolates 115 and Indo84 were tested. ${ }^{3}$ Four other banana Fusarium spp. VCGs (R1, R2, NRRL36103 and NRRL36113) were not tested.

\section{Feasibility of TR4 LAMP assay for in-plant diagnosis}

The developed TR4 LAMP assay successfully detected the presence of TR4 in tissue from inoculated plants under greenhouse conditions at WUR (average Tp $=16: 06 \mathrm{~min}$ and $\mathrm{Tm}$ $=82.9{ }^{\circ} \mathrm{C}$ ) and field conditions in The Philippines (average $\mathrm{Tp}=19: 26 \mathrm{~min}$ and $\mathrm{Tm}=83.0{ }^{\circ} \mathrm{C}$ ) (Table 4). 
A

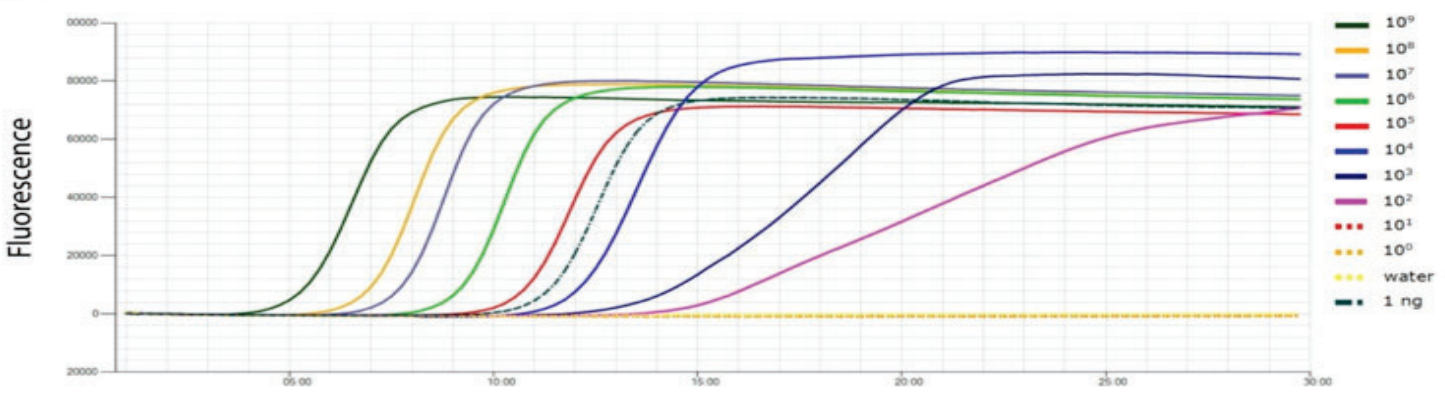

B

Time $(\min )$

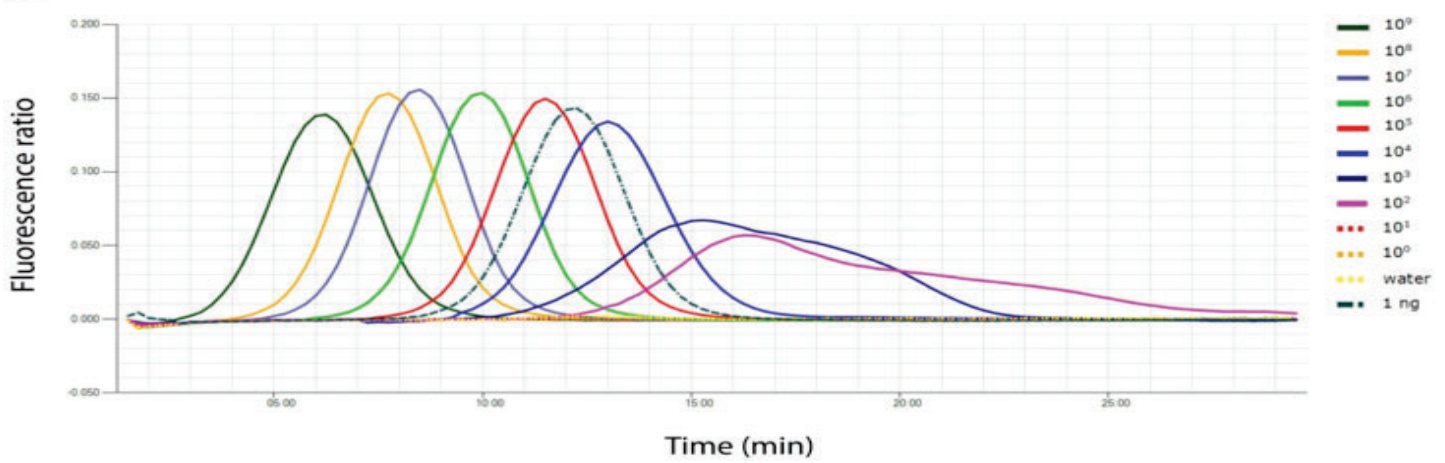

$\mathbf{C}$

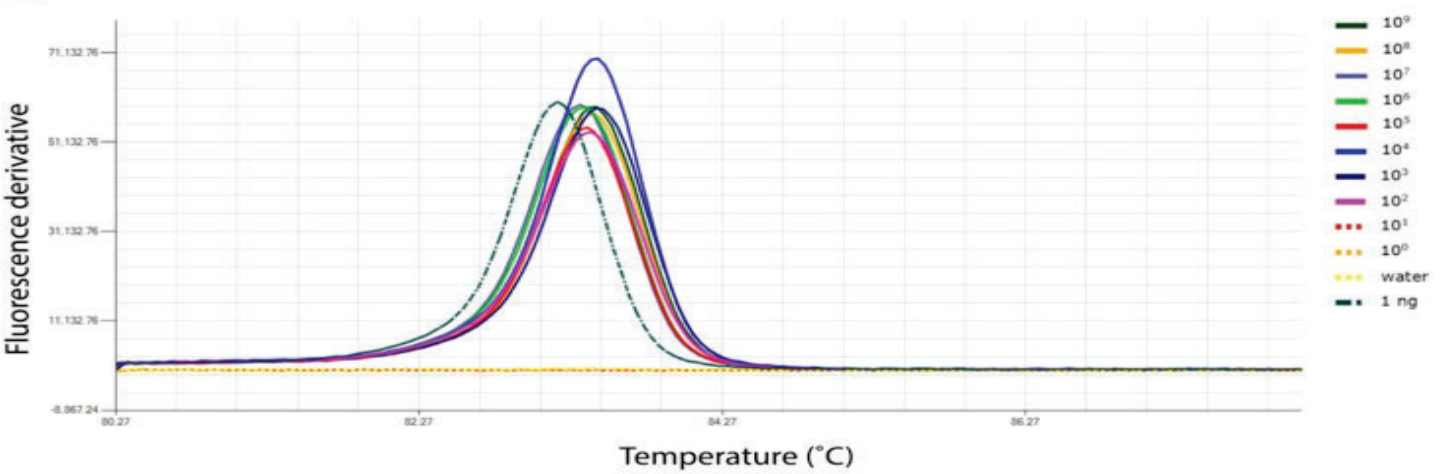

Figure 5. Sensitivity of the TR4 LAMP assay on the dilution series ( $10^{9}$ to $10^{\circ}$ copies per reaction) of the plasmid DNA containing the SeqA sequence. In each run, $1 \mathrm{ng}$ of pure TR4 II5 DNA and nuclease-free water were included as positive and negative control, respectively. (A) Amplification curves, (B) time of positivity (Tp) and (C) melting temperature $(\mathrm{Tm})$. 
Table 4. Performance of the developed LAMP assays on 'Grand Naine' banana tissues collected from artificially and naturally TR4 symptomatic plants at WUR, The Netherlands and in The Philippines. Tp stands for "time of positivity". Tm stands for "melting temperature".

\begin{tabular}{|c|c|c|c|c|c|c|}
\hline \multirow[t]{2}{*}{ Location } & \multirow[t]{2}{*}{ Sample } & \multirow[t]{2}{*}{ Replicate } & LAMP & TR4 assay & $\begin{array}{l}\text { LAMP } \\
\text { assay }\end{array}$ & MusaCox \\
\hline & & & $\mathrm{Tp}$ & $\mathrm{Tm}$ & Tp & $\mathrm{Tm}$ \\
\hline \multirow{16}{*}{$\begin{array}{l}\text { Greenhouse } \\
\text { (WUR, } \\
\text { Netherlands) }\end{array}$} & \multirow{4}{*}{$\begin{array}{l}\text { Healthy } \\
\text { rhizome } 1\end{array}$} & Extraction 1- Replicate 1 & - & - & $10: 15$ & 86.3 \\
\hline & & Extraction 1- Replicate 2 & - & - & $10: 15$ & 86.2 \\
\hline & & Extraction 2- Replicate 1 & - & - & $11: 00$ & 86.1 \\
\hline & & Extraction 2- Replicate 2 & - & - & $11: 15$ & 86.1 \\
\hline & \multirow{4}{*}{$\begin{array}{l}\text { Healthy } \\
\text { rhizome } 2\end{array}$} & Extraction 1- Replicate 1 & - & - & $10: 15$ & 86.0 \\
\hline & & Extraction 1- Replicate 2 & - & - & $10: 00$ & 86.1 \\
\hline & & Extraction 2- Replicate 1 & - & - & $10: 15$ & 86.3 \\
\hline & & Extraction 2- Replicate 2 & - & - & $10: 15$ & 86.2 \\
\hline & \multirow{4}{*}{$\begin{array}{l}\text { Infected } \\
\text { rhizome } 1\end{array}$} & Extraction 1- Replicate 1 & $14: 30$ & 83.1 & $10: 45$ & 86.0 \\
\hline & & Extraction 1- Replicate 2 & $14: 30$ & 83.1 & $10: 45$ & 86.0 \\
\hline & & Extraction 2- Replicate 1 & $15: 00$ & 83.0 & $11: 30$ & 86.0 \\
\hline & & Extraction 2- Replicate 2 & $15: 00$ & 83.0 & $11: 15$ & 86.0 \\
\hline & \multirow{4}{*}{$\begin{array}{l}\text { Infected } \\
\text { rhizome } 2\end{array}$} & Extraction 1- Replicate 1 & $18: 00$ & 83.0 & $11: 30$ & 85.9 \\
\hline & & Extraction 1- Replicate 2 & $17: 30$ & 83.0 & $11: 30$ & 85.9 \\
\hline & & Extraction 2- Replicate 1 & $17: 30$ & 83.0 & $12: 15$ & 85.9 \\
\hline & & Extraction 2- Replicate 2 & $17: 30$ & 82.7 & $12: 00$ & 85.9 \\
\hline \multirow{24}{*}{$\begin{array}{l}\text { Field } \\
\text { (Philippines) }\end{array}$} & \multirow{6}{*}{$\begin{array}{l}\text { Healthy } \\
\text { rhizome }\end{array}$} & Extraction 1- Replicate 1 & - & - & $19: 30$ & 86.0 \\
\hline & & Extraction 1- Replicate 2 & - & - & $18: 30$ & 86.1 \\
\hline & & Extraction 2- Replicate 1 & - & - & $17: 00$ & 86.2 \\
\hline & & Extraction 2- Replicate 2 & - & - & $17: 15$ & 86.1 \\
\hline & & Extraction 3- Replicate 1 & - & - & $17: 45$ & 86.0 \\
\hline & & Extraction 3- Replicate 2 & - & - & 23:00 & 85.9 \\
\hline & \multirow{6}{*}{$\begin{array}{l}\text { Healthy } \\
\text { pseudostem }\end{array}$} & Extraction 1- Replicate 1 & - & - & $22: 00$ & 86.0 \\
\hline & & Extraction 1- Replicate 2 & - & - & $21: 45$ & 86.1 \\
\hline & & Extraction 2- Replicate 1 & - & - & $22: 45$ & 86.1 \\
\hline & & Extraction 2- Replicate 2 & - & - & 23:00 & 86.1 \\
\hline & & Extraction 3- Replicate 1 & - & - & 23:00 & 86.1 \\
\hline & & Extraction 3- Replicate 2 & - & - & $22: 45$ & 86.1 \\
\hline & \multirow{6}{*}{$\begin{array}{l}\text { Infected } \\
\text { rhizome }\end{array}$} & Extraction 1- Replicate 1 & 23:00 & 82.9 & $13: 30$ & 86.1 \\
\hline & & Extraction 1- Replicate 2 & 19.45 & 83.1 & $13: 30$ & 86.2 \\
\hline & & Extraction 2- Replicate 1 & $18: 30$ & 83.1 & $14: 15$ & 86.2 \\
\hline & & Extraction 2- Replicate 2 & $21: 45$ & 83.1 & $14: 15$ & 86.2 \\
\hline & & Extraction 3- Replicate 1 & $18: 30$ & 83.1 & $14: 00$ & 86.2 \\
\hline & & Extraction 3- Replicate 2 & 19:15 & 83.1 & $14: 30$ & 86.2 \\
\hline & \multirow[t]{6}{*}{$\begin{array}{l}\text { Infected } \\
\text { pseudostem }\end{array}$} & Extraction 1- Replicate 1 & $16: 15$ & 83.1 & $14: 00$ & 86.1 \\
\hline & & Extraction 1- Replicate 2 & $17: 45$ & 83.1 & $17: 45$ & 86.1 \\
\hline & & Extraction 2- Replicate 1 & $17: 15$ & 83.3 & $15: 00$ & 86.1 \\
\hline & & Extraction 2- Replicate 2 & $22: 15$ & 83.1 & $15: 00$ & 86.1 \\
\hline & & Extraction 3- Replicate 1 & 20:15 & 83.0 & $15: 00$ & 86.2 \\
\hline & & Extraction 3- Replicate 2 & $18: 45$ & 83.0 & $18: 00$ & 86.0 \\
\hline
\end{tabular}


In healthy control plants, TR4 was never detected. Under field conditions, TR4 LAMP assays were performed in banana plantations as proof of the simple requirements to run the assay (sFigure 1). All plant tissue samples were positive for the LAMP MusaCox assay (average $\mathrm{Tp}=14: 23$ and $\mathrm{Tm}=86.0^{\circ} \mathrm{C}$ ). The Tm was specific and unique for TR4 and cox1 products, corresponding to $82.9^{\circ} \mathrm{C}$ and $86.0^{\circ} \mathrm{C}$ respectively. This temperature difference allows discrimination between the two amplicons generated in the same reaction. In summary, the TR4 LAMP assay proved to be successful in detecting TR4 in artificially as well as in the naturally infected plants, showing that this assay is feasible for in-plant diagnosis in an undemanding setting in the field.

\section{Discussion}

Crop losses due to the incidence of pests can significantly threaten food security (Bebber \& Gurr, 2014; Fisher et al., 2016; Gurr et al., 2011). Estimates of potential and actual losses due to plant pests despite the current crop protection practices varied from $50 \%$ in wheat to more than $80 \%$ in cotton production (Oerke, 2005). Currently in bananas, the emerging TR4 strain causing Panama disease may potentially develop into a pandemic (Butler, 2013; Kema \& Weise, 2013; Kupferschmidt, 2012; Ordóñez et al., 2015; Pearce, 2003) as it occurred during the first outbreak of the disease in Latin America (Ploetz, 1994; Stover, 1962). The species responsible for the current outbreak on bananas is F. odoratissimum (Maryani et al., 2019), which comprises TR4 (Molina et al., 2009; Ordóñez et al., 2015; Ploetz, 2015a, 2015b; Maryani et al., 2019) and has disseminated, since its first encounter with Cavendish in Taiwan (Ploetz, 2006), within and outside of Southeast Asia (Chittarath et al., 2017; García et al., 2014; Hung et al., 2017; Mostert et al., 2017; Ordóñez et al., 2016; Ordóñez et al., 2015; Zheng et al., 2018), affecting by now an estimated area of $>100,000$ ha. of banana plantations (Ordóñez et al., 2015). As there is no known effective and long-term control of the disease, global awareness among banana-growing countries are directed towards prevention of further spread of the pathogen (FAO, 2014), which requires accurate diagnosis. In this study, we developed a LAMP assay that enables on-site diagnosis of TR4 in the field. Diagnosis of plant pathogens is the cornerstone of effective disease control and prevention (Schaad et al., 2003). For molecular-based diagnostic development, targeting of unique genome sequences is essential. Thus in the current study, we used DArTseq to identify TR4 specific sequences that were fully absent from other previously identified Fusarium spp. causing Panama disease, comprising a suite of VCGs. The sequence extension upon selection of our DArTseq markers benefitted from available Fusarium genomes that aided the development of our TR4 LAMP assay. Since there is no public genomic data on all 24 previously identified VCGs, our selected sequence (SeqA) was further tested via PCR reactions on isolates representing each of these genotypes. Currently, there are four publicy available genomes that correspond to two TR4 isolates (VCG01213) and two isolates of unknown VCG. Also, 94 genomes corresponding to F. oxysporum strains pathogenic to other hosts are available (http://www.ncbi.nlm.nih.gov/genome/genomes/707). Here, our extended TR4 sequence (SeqA) proved to be specific to TR4 genomes available in the two databases used in this study. Certainly, whole-sequencing projects on a larger suite of 
Fusarium genomes and other members of the polyphyletic Fusarium spp. causing Panama disease will facilitate the development and improvement of molecular-based diagnostic tools.

Specificity of molecular-based diagnostics is indispensable to ensure an accurate diagnosis of pathogens, thus ideally development of diagnostic tools must include a diverse set of relevant isolates. The comparison of our developed TR4 LAMP assay to the previously developed TR4 LAMP assay (Zhang et al., 2013) showed that the latter cannot discriminate TR4 (VCG01213) from other Fusarium VCGs involved in Panama disease, despite carefully following the described protocol. Since the B3 and F3 LAMP primers (Zhang et al., 2013) are the same as the PCR primers for TR4 (Dita et al., 2010), the unspecificity of this LAMP assay likely is due to other components of this LAMP assay (LoopF, LoopB, B2, F2, F1c and B1c). Moreover, our assay is grounded in the widest possible genetic diversity of Fusarium spp. associated with Panama diseaase development, whereas the LAMP assay of Zhang et al. (2013) was developed on a single TR4 isolate and just five other isolates. In our study, the new TR4 LAMP assay was highly specific to TR4. Non-target species, including $R$. solanacearum, a bacterium that causes similar wilting symptoms on bananas as those elicited by compatible Fusarium strains (Blomme et al., 2017; Kubota et al., 2008), did not result in an amplicon. The sensitivity of our LAMP assay is excellent as it detects volumes as low as $1 \mathrm{pg} / \mu \mathrm{l}$ or $10^{2}$ copies of plasmid DNA per reaction and from $1 \mathrm{ng}$ pure TR4 DNA with an excellent reproducibility and amplification efficiency despite the presence of background DNA. This corroborates with a previous report stating that LAMP assays are less influenced by nontarget DNA compared to other molecular diagnostics (Kaneko et al., 2007). In LAMP assays, target genome sequences can be detected faster than with other molecular diagnostics (Notomi et al., 2000). Diagnosis of TR4 in suspicious plant samples following a simple and quick DNA extraction procedure was completed in $30 \mathrm{~min}$ for 12 in parallel samples. Hence, this new LAMP is a ready to use and on-site solution for routine TR4 diagnosis that supports the implementation of cordoning and quarantine strategies.

Contrary to LAMP, PCR-based molecular diagnostics for TR4 (Dita et al., 2010; Li et al., 2013a, Li et al., 2013b) require advanced laboratory facilities and expertise. In banana, the most important pathogens such as bunchy top virus (Peng et al., 2012a), cucumber mosaic virus (Peng et al., 2012b), streak virus (Peng et al., 2012c) and the Moko pathogen $R$. solanacearum (Kubota et al., 2008) can now be detected using LAMP technology. These assays are particularly relevant to reduce the time between the introduction of a pathogen and its detection. Usually, considerable time elapses between the incursion of a plant pathogen and its diagnosis, generating greater economic losses (Stack et al., 2006). In Jordan, Panama disease symptoms on Cavendish plants were first observed in 2006, but TR4 was only diagnosed after eight years (García et al., 2014), in the meantine TR4 had spread to new farms in the country and some banana farms are nowadays abandoned (Ploetz et al., 2015b). Similarly in Taiwan, TR4 was identified only in 1994, but wilting Cavendish was observed in the 1960s and hence, nowadays TR4 is widely spread across Southeast Asia (Molina et al., 2009; Zheng et al., 2018). A global analysis of crop pathogen distributions 
showed that a country's ability to accurately monitor and report its pathogen load increases its research capacity and expenditure with per capita gross domestic product (Bebber et al., 2014). Since LAMP assays require low cost materials and non-experienced personnel, the TR4 LAMP assay was pioneered for three years in the Philippines to test its rapid implementation in resource poor environments for on-site detection and the cordoning of TR4 to minimize economic losses (Frison \& Sharrock, 1998; IOM, 2007). Indeed, in these farms, new TR4 incursions are being identified and correctly diagnosed, thereby supporting immediate quarantine actions. We conclude that the developed LAMP technology is of great value and provides immediate information on TR4 hotspots and, most importantly, the ability to set off routine surveillance and eradication plans.

\section{Acknowledgments}

This research is funded by the Interdisciplinary Research and Education Fund (INREF) of Wageningen University \& Research (WUR), Wageningen, The Netherlands. Banana research at WUR is supported by the Dutch Dioraphte Foundation endowed chair in Tropical Phytopathology of GHJK at the WUR-Laboratory of Phytopathology. Research in the laboratory of M.F.S. is supported by the Research Council Earth and Life Science (ALW) of The Netherlands Organization of Scientific Research (NWO). NEH-Philippines generously supported field experimentation and Tadeco-Philippines provided Moko isolates from Cavendish banana. We thank Rahan Meristem, Israel, for providing all greenhouse plants for experimentation and Nani Maryani for making infected plants available for this project. UNIFARM, WUR, The Netherlands is greatly acknowledged for greenhouse maintenance and plant care. 

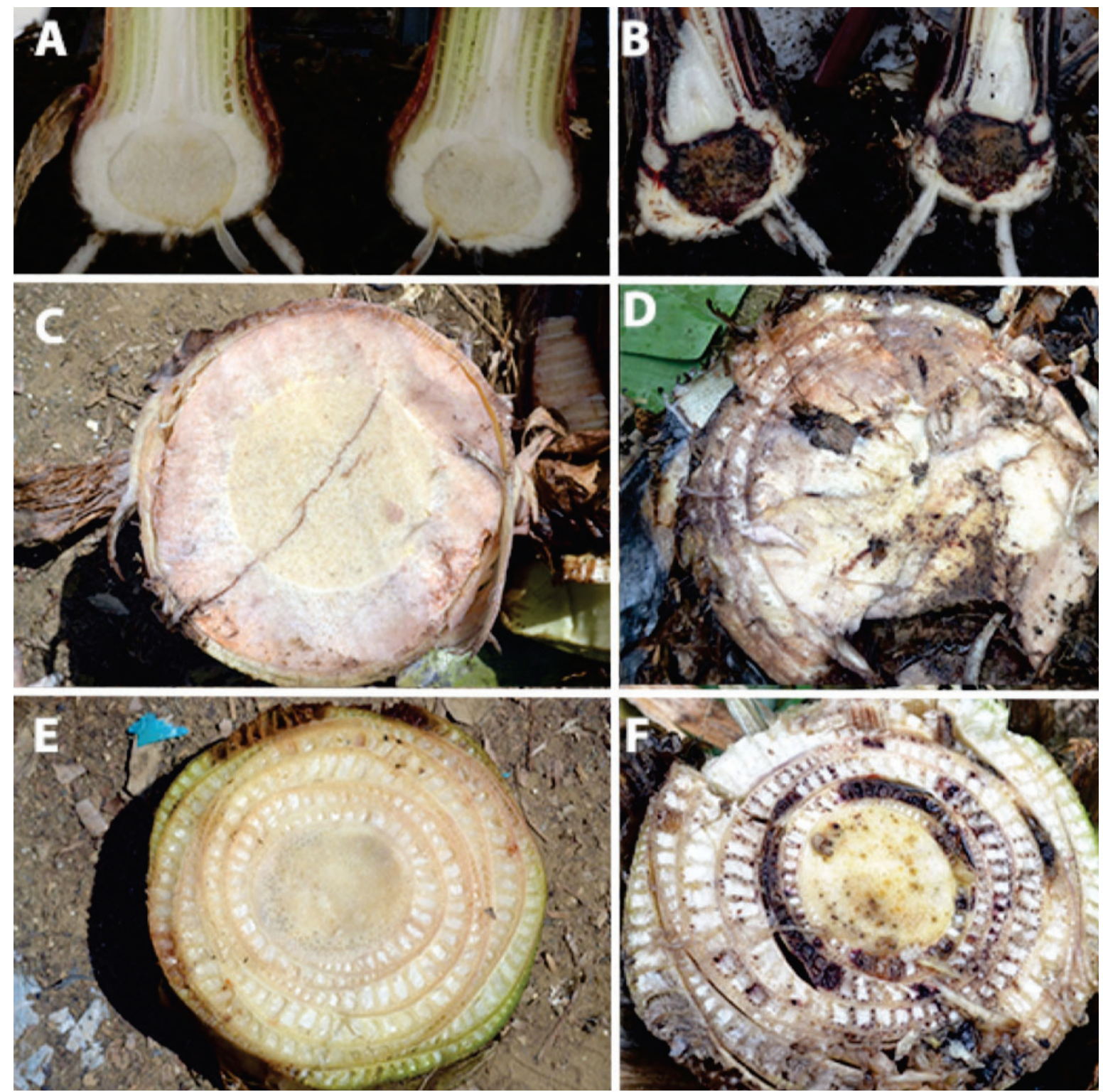

sFigure 1. 'Grand Naine' samples evaluated using the developed LAMP TR4 and MusaCox assays.

(A) Healthy (water-control) and (B) infected rhizome under greenhouse conditions at WUR, The Netherlands; (C) healthy and (D) infected rhizome and (E) healthy and (F) infected pseudostem in field conditions in The Philippines. 
sTable 1. Response of TR4 and non-TR4 isolates to the developed TR4 LAMP assay. Positive results for TR4 LAMP assays are indicated as "+", while negative results are indicated as "-". n.d.stands for "not determined". n.a. stands for "not applicable". n.t. stands for "not tested".

\begin{tabular}{|c|c|c|c|c|}
\hline Isolate code & Species & VCG & $\begin{array}{l}\text { LAMP TR4 } \\
\text { this study }\end{array}$ & $\begin{array}{l}\text { LAMP TR4 } \\
\text { (Zhang et al., 2013) }\end{array}$ \\
\hline \multicolumn{5}{|l|}{ TR4 isolates } \\
\hline 24662 & Fusarium oxysporum f.sp. cubense & $01213 / 16$ & + & n.t. \\
\hline 24663 & F. oxysporum f.sp. cubense & $01213 / 16$ & + & n.t. \\
\hline 24664 & F. oxysporum f.sp. cubense & $01213 / 16$ & + & n.t. \\
\hline BPS1.1 & F. oxysporum f.sp. cubense & 01213 & + & n.t. \\
\hline BPS3.1 & F. oxysporum f.sp. cubense & 01213 & + & n.t. \\
\hline Foc.T105 & F. oxysporum f.sp. cubense & 01213 & + & n.t. \\
\hline II5 & F. oxysporum f.sp. cubense & 01213 & + & + \\
\hline Indo84 & F. oxysporum f.sp. cubense & 01216 & + & + \\
\hline Indo87 & F. oxysporum f.sp. cubense & $01213 / 16$ & + & n.t. \\
\hline JV11 & F. oxysporum f.sp. cubense & 01213 & + & n.t. \\
\hline Leb1.1A & F. oxysporum f.sp. cubense & 01213 & + & n.t. \\
\hline Leb1.2C & F. oxysporum f.sp. cubense & 01213 & + & n.t. \\
\hline Mal123 & F. oxysporum f.sp. cubense & 01213 & + & n.t. \\
\hline NRRL36114 & F. oxysporum f.sp. cubense & 01213 & + & n.t. \\
\hline Pak1.1A & F. oxysporum f.sp. cubense & 01213 & + & n.t. \\
\hline Phi1.1A & F. oxysporum f.sp. cubense & 01213 & + & n.t. \\
\hline Phi2.5C & F. oxysporum f.sp. cubense & 01213 & + & n.t. \\
\hline Phi3.4C & F. oxysporum f.sp. cubense & 01213 & + & n.t. \\
\hline Phi4.5A & F. oxysporum f.sp. cubense & 01213 & + & n.t. \\
\hline Phi5.2A & F. oxysporum f.sp. cubense & 01213 & + & n.t. \\
\hline RPML47 & F. oxysporum f.sp. cubense & $01213 / 16$ & + & n.t. \\
\hline STSUM2 & F. oxysporum f.sp. cubense & 01213 & + & n.t. \\
\hline \multicolumn{5}{|c|}{ Non - TR4 isolates } \\
\hline FocST498 & F. oxysporum f.sp. cubense & 0120 & - & + \\
\hline NRRL25603 & F. oxysporum f.sp. cubense & $0120 / 15$ & - & + \\
\hline NRRL36102 & F. oxysporum f.sp. cubense & 0121 & - & + \\
\hline NRRL36103 & F. oxysporum f.sp. cubense & 0122 & - & n.t. \\
\hline F9129 1 & F. oxysporum f.sp. cubense & 0123 & - & + \\
\hline NRRL36105 & F. oxysporum f.sp. cubense & 0124 & - & + \\
\hline Foc_R2 & F. oxysporum f.sp. cubense & 0124 & - & n.t. \\
\hline NRRL36106 & F. oxysporum f.sp. cubense & 0125 & - & + \\
\hline NRRL36107 ${ }^{1}$ & F. oxysporum f.sp. cubense & 0126 & - & + \\
\hline NRRL36111 & F. oxysporum f.sp. cubense & 0128 & - & + \\
\hline NRRL36110 & F. oxysporum f.sp. cubense & 0129 & - & + \\
\hline Focu $7^{1}$ & F. oxysporum f.sp. cubense & 01210 & - & + \\
\hline NRRL36109 & F. oxysporum f.sp. cubense & 01211 & - & + \\
\hline NRRL36108 & F. oxysporum f.sp. cubense & 01212 & - & + \\
\hline NRRL36113 & F. oxysporum f.sp. cubense & 01214 & - & n.t. \\
\hline
\end{tabular}




\begin{tabular}{|c|c|c|c|c|}
\hline Isolate code & Species & VCG & $\begin{array}{l}\text { LAMP TR4 } \\
\text { this study }\end{array}$ & $\begin{array}{l}\text { LAMP TR4 } \\
\text { (Zhang et al., 2013) }\end{array}$ \\
\hline NRRL25609 & F. oxysporum f.sp. cubense & 01214 & - & + \\
\hline NRRL36112 & F. oxysporum f.sp. cubense & 01215 & - & + \\
\hline Mal43 & F. oxysporum f.sp. cubense & 01217 & - & + \\
\hline NRRL36120 & F. oxysporum f.sp. cubense & 01218 & - & + \\
\hline Indo25 & F. oxysporum f.sp. cubense & 01219 & - & + \\
\hline 242181 & F. oxysporum f.sp. cubense & 01220 & - & + \\
\hline NRRL36118 & F. oxysporum f.sp. cubense & 01221 & - & + \\
\hline NRRL36117 & F. oxysporum f.sp. cubense & 01222 & - & + \\
\hline NRRL36116 & F. oxysporum f.sp. cubense & 01223 & - & + \\
\hline NRRL36115 & F. oxysporum f.sp. cubense & 01224 & - & + \\
\hline Foc_R1 & F. oxysporum f.sp. cubense & n.d. & - & n.t. \\
\hline KDM1.2A & F. oxysporum f.sp. cubense & n.d. & - & n.t. \\
\hline Mal1.5B & F. oxysporum f.sp. cubense & n.d. & - & n.t. \\
\hline 0.1879 & F. oxysporum f.sp. melongenae & n.d. & - & n.t. \\
\hline 0.1954 & F. oxysporum f.sp. canariensis & n.d. & - & n.t. \\
\hline CBS196.65 & F. oxysporum f.sp. narcissi & n.d. & - & n.t. \\
\hline Fo47 & F. oxysporum & n.d. & - & n.t. \\
\hline Fol4287 & F. oxysporum f.sp. lycopersici & n.d. & - & n.t. \\
\hline Fop.08.1 & F. oxysporum f.sp. passiflora & n.d. & - & n.t. \\
\hline NRRL25433 & F. oxysporum f.sp. vasinfectum & n.d. & - & n.t. \\
\hline NRRL26035/ IP099.03 & F. oxysporum f.sp. canariensis & n.d. & - & n.t. \\
\hline NRRL26381/ CL57 & F. oxysporum f.sp. radicis-lycopersici & n.d. & - & n.t. \\
\hline NRRL26406/ Fom001 & F. oxysporum f.sp. melonis & n.d. & - & n.t. \\
\hline NRRL26761/ IP099.04 & F. oxysporum f.sp. phaseoli & n.d. & - & n.t. \\
\hline NRRL28781/ IP099.02 & F. oxysporum f.sp. erythroxyli & n.d. & - & n.t. \\
\hline NRRL37622/ HDV247 & F. oxysporum f.sp. pisi & n.d. & - & n.t. \\
\hline NRRL54005/ PHW815 & F. oxysporum f.sp. raphani & n.d. & - & n.t. \\
\hline NRRL54008/ PHW808 & F. oxysporum f.sp. conglutinans & n.d. & - & n.t. \\
\hline CBS221.76 & Fusarium fujikuroi & n.a. & - & n.t. \\
\hline Moko & Ralstonia solanacearum & n.a. & - & n.t. \\
\hline
\end{tabular}




\section{References}

Alves, A., Pereira, V., Leão, A., Formigheri, E., de Capdeville, G., \& Souza Junior, M. (2014). Advancing palm genomics by developing a high-density battery of molecular markers for Elaeis oleifera for future downstream applications. BMC Proceeding, 8(Suppl 4), P96.

Bebber, D.P., Holmes, T., Smith, D., \& Gurr, S J. (2014). Economic and physical determinants of the global distributions of crop pests and pathogens. New Phytopalogist 202(3), 901-910.

Bebber, D.P., Ramotowski, M.A.T., \& Gurr, S.J. (2013). Crop pests and pathogens move polewards in a warming world. Nature Climate Change 3: 985.

Bentley, S., Pegg, K.G., Moore, N.Y., Davis, R.D., \& Buddenhagen, I. (1998). Genetic variation among vegetative compatibility groups of Fusarium oxysporum f.sp. cubense analyzed by DNA fingerprinting. Phytopathology 88(12): 1283-1293.

Blomme, G., Dita, M., Jacobsen, K.S., Pérez Vicente, L., Molina, A., Ocimati, W., . . Prior, P. (2017). Bacterial diseases of bananas and Enset: Current state of knowledge and integrated approaches toward sustainable management. Frontiers in Plant Science 8(1290): 1-25.

Buddenhagen, I. (2009). Understanding strain diversity in Fusarium oxysporum f.sp. cubense and history of introduction of Tropical Race 4 to better manage banana production. Acta Horticulturae 828 (Proc. IS on Banana Crop Prot., Sust. Prod. \& Impr. Livelihoods), 193-204.

Bühlmann, A., Pothier, J.F., Rezzonico, F., Smits, T.H.M., Andreou, M., Boonham, N., . . Frey, J.E. (2013). Erwinia amylovora loop-mediated isothermal amplification (LAMP) assay for rapid pathogen detection and on-site diagnosis of fire blight. Journal of Microbiological Methods 92(3): 332-339.

Butler, D. (2013). Fungus threatens top banana. Nature 504: 195-196.

Chittarath, K., Mostert, D., Crew, K.S., Viljoen, A., Kong, G., Molina, G., \& Thomas, J.E. (2017). First report of Fusarium oxysporum f.sp. cubense tropical race 4 (VCG 01213/16) associated with Cavendish bananas in Laos. Plant Disease: 449.

Cruz, V.M., Kilian, A., \& Dierig, D.A. (2013). Development of DArT marker platforms and genetic diversity assessment of the U.S. collection of the new oilseed crop lesquerella and related species. PLoS One 8(5): 1-13.

Dita, M.A., Waalwijk, C., Buddenhagen, I.W., Souza Jr, M.T., \& Kema, G.H.J. (2010). A molecular diagnostic for tropical race 4 of the banana Fusarium wilt pathogen. Plant Pathology 59(2): 348357.

FAO. (2014). Technical manual prevention and diagnostic of Fusarium Wilt (Panama disease) of banana caused by Fusarium oxysporum f.sp. cubense Tropical Race 4 (TR4).

Fisher, M.C., Gow, N.A., \& Gurr, S.J. (2016). Tackling emerging fungal threats to animal health, food security and ecosystem resilience. Philosophical Transactions of the Royal Society London 371(1709).

Frison, E., \& Sharrock, S. (1998). The economic, social and nutritional importance of banana in the world. Paper presented at the Bananas and food security, Douala, Cameroon.

García, F.A., van der Veen, A.J.T., Nakasato-Tagami, G., Meijer, H.J.G., Arango-Isaza, R.E., \& Kema, G.H.J. (2019a). An improved spore production protocol facilitates a high throughput phenotyping assay for the banana - Fusarium oxysporum f.sp. cubense pathosystem. (PhD Degree), Wageningen University \& Research, Wageningen, The Netherlands. 
García, F.A., Bakry, F., Irish, B., \& Kema, G.H.J. (2019b). Evidence for wide variation of resistance to Fusarium oxysporum f.sp. cubense tropical race 4 and race 1 generated by vegetative propagation in banana. (PhD Degree), Wageningen University \& Research, Wageningen, The Netherlands.

García, F., Ordóñez, N., Konkol, J., Al-Qasim, M., Naser, Z., Abdelwali, M., .. Kema, G.H.J. (2014). First report of Fusarium oxysporum f.sp. cubense tropical race 4 associated with Panama disease of banana outside Southeast Asia. Plant Diease 98(5): 694.

Gurr, S., Samalova, M., \& Fisher, M. (2011). The rise and rise of emerging infectious fungi challenges food security and ecosystem health. Fungal Biology Review 25(4):181-188.

Harper, S.J., Ward, L.I., \& Clover, G.R.G. (2010). Development of LAMP and Real-Time PCR methods for the rapid detection of Xylella fastidiosa for quarantine and field applications. Phytopathology 100(12): 1282-1288.

Hung, T.N., Hung, N.Q., Mostert, D., Viljoen, A., Chao, C.P., \& Molina, G. (2017). First report of Fusarium wilt on Cavendish bananas, caused by Fusarium oxysporum f.sp. cubense tropical race 4 (VCG 01213/16), in Vietnam. Plant Disease 448.

Hwang, S.C., \& Ko, W.H. (2004). Cavendish banana cultivars resistant to Fusarium wilt acquired through somaclonal variation in Taiwan somaclonal variation in Taiwan. Plant Disease 88(6): 580-588.

IOM. (2007). Global Infectious Disease Surveillance and Detection: Assessing the Challenges-Finding Solutions, Workshop Summary. Washington (DC): National Academies Press (US).

Kaneko, H., Kawana, T., Fukushima, E., \& Suzutani, T. (2007). Tolerance of loop-mediated isothermal amplification to a culture medium and biological substances. Journal of Biochemical and Biophysical Methods, 70(3): 499-501.

Kelman, A. (1954). The relationship of pathogenicity in Pseudomonas solanacearum to colony appearance on a tetrazolium medium. Phytopathology 64: 693-695.

Kema, G.H.J., \& Weise, S. (2013). Pathogens: Appeal for funds to fight banana blight. Nature 504(7479): 218.

Kistler, H.C., Alabouvette, C., Baayen, R.P., Bentley, S., Brayford, D., Coddington, A., . . . Woo, S. (1998). Systematic numbering of vegetative compatibility groups in the plant pathogenic fungus Fusarium oxysporum. Phytopathology 88(1): 30-32.

Kubota, R., Vine, B.G., Alvarez, A.M., \& Jenkins, D.M. (2008). Detection of Ralstonia solanacearum by Loop-Mediated Isothermal Amplification. Phytopathology 98(9): 1045-1051.

Kupferschmidt, K. (2012). Attack of the clones. Science 337:636-638.

Leslie, J.F., \& Summerell, B. (2006). The Fusarium Laboratory Manual: Blackwell Publishing.

Li, M.H., Shi, J.X., Xie, X.L., Leng, Y.Q., Wang, H.F., Xi, P.G., . . Jiang, Z.D. (2013a). Identification and application of a unique genetic locus in diagnosis of Fusarium oxysporum f.sp cubense tropical race 4. Canadian Journal of Plant Pathology 35(4): 482-493.

Li, C.Y., Mostert, G., Zuo, C.W., Beukes, I., Yang, Q.S., Sheng, O., . . Y Yi, G.J. (2013b). Diversity and distribution of the banana wilt pathogen Fusarium oxysporum f.sp. cubense in China. Fungal Genome Biology 3(2): 1-6.

Maryani, N., Lombard, L., Poerba, Y.S., Subandiyah, S., Crous, P.W. and Kema, G.H.J. (2019) Phylogeny and genetic diversity of the banana Fusarium wilt pathogen Fusarium oxysporum f.sp. cubense in the Indonesian centre of origin. Studies in Mycology 92:155-194.

Maymon, M. Shpatz, U., Shpatz, U., Harel, , Y.M., Levy, E., Elkind, , G., Teverovsky, E.,..... Israeli, Y. and Freeman, S. (2018) First Report of Fusarium oxysporum f. sp. cubenseTropical Race 4 Causing Fusarium Wilt of Cavendish Bananas in Israel. Plant Disease 102 (12):2655. 
Molina, A.B., Fabregar, E., Sinohin, V.G., Yi, G., \& Viljoen, A. (2009). Recent occurrence of Fusarium oxysporum f.sp. cubense tropical race 4 in Asia. Acta Horticulturae, 828 (Proc. IS on Banana Crop Prot., Sust. Prod. \& Impr. Livelihoods), 109-115.

Mostert, D., Molina, A.B., Daniells, J., Fourie, G., Hermanto, C., Chao, C. P., . . Viljoen, A. (2017). The distribution and host range of the banana Fusarium wilt fungus, Fusarium oxysporum f.sp. cubense, in Asia. PLoS One 12(7): 1-24.

Nagamine, K., Kuzuhara, Y., \& Notomi, T. (2002). Isolation of single-stranded DNA from Loop-Mediated Isothermal Amplification products. Journal of Biochemical and Biophysical Research 290(4): 1195-1198.

Notomi, T., Okayama, H., Masubuchi, H., Yonekawa, T., Watanabe, K., Amino, N., \& Hase, T. (2000). Loop-mediated isothermal amplification of DNA. Nucleic Acids Reearch 28(12).

Oerke, E. C. (2005). Crop losses to pests. Journal of Agricultural Science 144(1):31-43.

O'Neill, W. T., Henderson, J., Pattemore, J. A., O'Dwyer, C., Perry, S., Beasley, D. R., et al. (2016). Detection of Fusarium oxysporum f. sp. cubensetropical race 4 strain in northern Queensland. Australasian Plant Disease Notes 11:33.

Ordóñez, N., García, F., Laghari, H.B., Akkary, M.Y., Harfouche, E.N., al Awar, B.N., \& Kema, G. H. J. (2016). First report of Fusarium oxysporum f.sp. cubense tropical race 4 causing Panama disease in Cavendish bananas in Pakistan and Lebanon. Plant Disease 100(1): 209.

Ordóñez, N., Seidl, M.F., Waalwijk, C., Drenth, A., Kilian, A., Thomma, B.P., . . Kema, G.H. (2015). Worse comes to worst: Bananas and Panama disease-when plant and pathogen clones meet. PLoS Pathogen 11(11): 1-7.

Pearce, F. (2003). Going bananas. New Scientist 177: 27.

Peng, J., Zhang, J., Xia, Z., Li, Y., Huang, J., \& Fan, Z. (2012a). Rapid and sensitive detection of Banana bunchy top virus by loop-mediated isothermal amplification. Journal of Virological Methods 185(2): 254-258.

Peng, J., Shi, M., Xia, Z., Huang, J., \& Fan, Z. (2012b). Detection of cucumber mosaic virus isolates from banana by one-step reverse transcription loop-mediated isothermal amplification. Archives of Virology 157(11): 2213-2217.

Peng, J., Fan, Z., \& Huang, J. (2012c). Rapid detection of banana streak virus by Loop-mediated Isothermal Amplification Assay in South China. Journal of Phytopathology 160(5): 248-250.

Ploetz, R.C. (2015a). Fusarium wilt of Banana. Phytopathology, 105(12), 1512-1521.Ploetz, R.C. (1994). Panama disease: Return of the first banana menace. International Journal of Pest Management 40(4): 326-336.

Ploetz, R.C. (2015b). Management of Fusarium wilt of banana: a review with special reference to tropical race 4. Crop Protection 73: 7-15.

Ploetz, R.C., Kema, G. H., \& Ma, L. J. (2015a). Impact of diseases on export and smallholder production of banana. Annual Review of Phytopathology 53: 269-288.

Ploetz, R.C., Freeman, S., Konkol, J., Al-Abed, A., Naser, Z., Shalan, K., . . Israeli, Y. (2015b). Tropical race 4 of Panama disease in the Middle East. Phytoparasitica 1-11.

Ploetz, R.C. (2006). Panama disease: An old nemesis rears its ugly head. Part2. The Cavendish era and beyond. Plant Health Progress.

Ploetz, R.C. (2005). Panama Disease: An old nemesis rears its ugly head. Part1: The beginnings of the banana export trades. Plant Health Progress. 
Sambrook, J., Fritsch, E.F., \& Maniatis, T. (1989). Molecular cloning: A laboratory manual. (2nd. ed. ed.). New York: Cold Spring Harbour Press.

Schaad, N.W., Frederick, R.D., Shaw, J., Schneider, W. L., Hickson, R., Petrillo, M. D., \& Luster, D. G. (2003). Advances in molecular-based diagnostics in meeting crop biosecurity and phytosanitary issues. Annual Review Phytopathology 41: 305-324.

Stack, J., Cardwell, K., Hammerschmidt, R., Byrne, J., Loria, R., Snover-Clift, K., . . Luke, E. (2006). The National Plant Diagnostic Network. Plant Disease 90(2): 128-136.

Stover, R.H. (1962). Fusarial wilt (Panama disease) of bananas and other Musa species. UK: Commonwealth Mycological Institute.

Thangavelu, R., Mostert, D., Gopi, M., Ganga Devi, P., Padmanaban, B., Molina, A.B. and Viljoen, A. (2019) First detection of Fusarium oxysporum f. sp. cubense tropical race 4 (TR4) on Cavendish banana in India. European Journal of Plant Pathology.

Tomlinson, J., \& Boonham, N. (2015). Real-Time LAMP for Chalara fraxinea diagnosis. Methods in Molecular Biology 1302: 75-83.

Untergasser, A., Nijveen, H., Rao, X., Bisseling, T., Geurts, R., \& Leunissen, J.A.M. (2007). Primer3Plus, an enhanced web interface to Primer3. Nucleic Acids Reearchs 35:W71-W74.

Zhang, X., Zhang, H., Pu, J., Qi, Y., Yu, Q., Xie, Y., \& Peng, J. (2013). Development of a real-time fluorescence loop-mediated isothermal amplification assay for rapid and quantitative detection of Fusarium oxysporum f.sp. cubense tropical race 4 in soil. PLoS One 8(12):1-10.

Zheng, S., García, F.A., Li, X., Zheng, L., Bai, T. T., Xu, S., . . Kema, G.H.J. (2018). New geographical insights of the latest expansion of Fusarium oxysporum f.sp. cubense tropical race 4 into the Greater Mekong subregion. Frontiers in Plant Science 9(457): 1-9. 

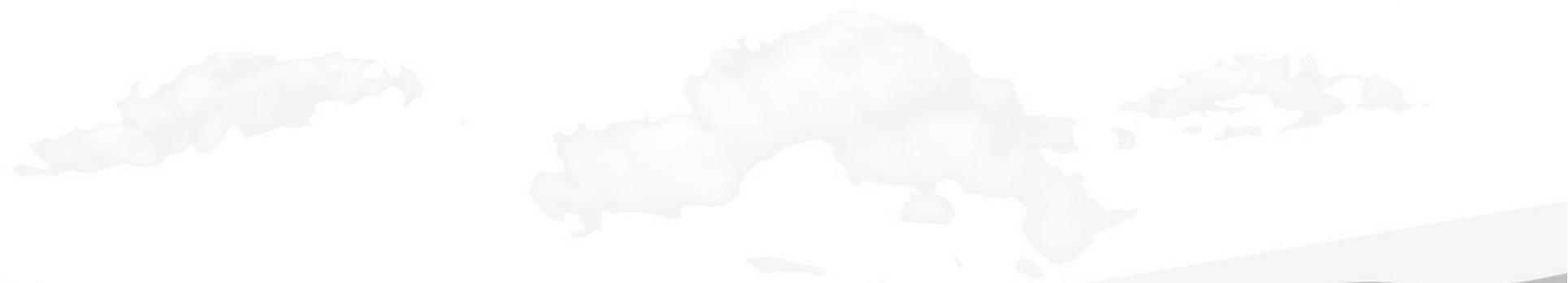

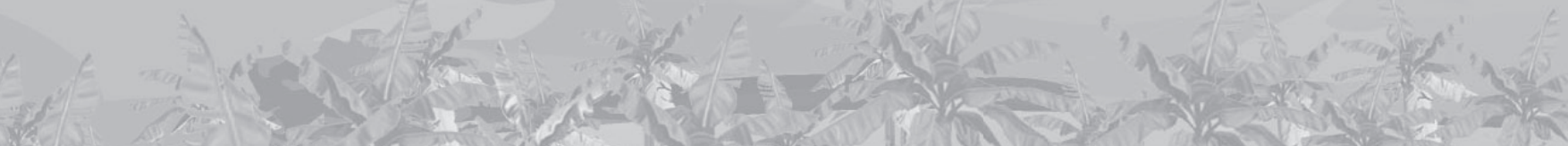

1.

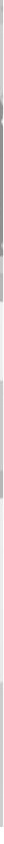


CHAPTER 3

\section{Epidemiology and management of Panama disease in the Mindanao Cavendish banana belt of the Philippines}

Salacinas, $\mathrm{MA}^{1}$, Stoorvogel, $\mathrm{J}^{1}$, Mendes, $\mathrm{O}^{1}$, Schoen, $\mathrm{C}^{1}$, Rebuta, $\mathrm{AM}^{2}$, Catambacan, $\mathrm{DG}^{2}$, Corcolon, $\mathrm{B}^{2}$, Tuba, J33, Mora, J3 ${ }^{3}$ Bacus, L ${ }^{4}$, Trüggelmann, $\mathrm{LT}^{4}$, Mamora, H.S. ${ }^{5}$, Meijer, $\mathrm{HJG}^{1}$, and Kema, $\mathrm{GHJ}^{1^{*}}$ 


\section{Abstract}

Panama disease in Cavendish banana is caused by the fungal pathogen Fusarium odoratissimum, which is colloquially called Tropical race 4 (TR4) and causes havoc in the global banana industry. In this study, we primarily focused on the spatial distribution of TR4 in naturally infested soils and water in the banana belt of the Philippines, but also investigated survival after commonly used management practices and in weeds. Inoculum of TR4 was detected as deep as $1 \mathrm{~m}$ below the surface of soils planted to the banana varieties Cavendish and Lakatan. Traceability and dissemination of TR4 inoculum was monitored by sampling footwear, which suggests that human trafficking is the major contributor to the short and long distance dissemination of TR4. Moreover, we confirmed TR4 inoculum in surface water of rivers and reservoirs in and bordering a commercial banana plantation that puts nearby banana farms at risk of TR4 infestation. We then tested the efficacy of commonly practiced field sanitation by burning (both rice hull and wood), determined temperature profiles across four different soil depths during the sanitation process, quantified the resulting inoculum reduction and tested the viability of remaining fungal biomass. Burning rice hull or wood results in different temperature levels and profiles and reduced chlamydospores viability of up to $0.4 \mathrm{~m}$ but not below the soil. Finally, we investigated TR4 presence in weeds and confirmed its presence in eight symptomless weed species belonging to seven botanical families growing in heavily infested natural banana soils. The collected epidemiological information contributes to developing efficacious Panama disease management practices until new varieties with required resistance levels to TR4 reach the market.

Keywords: Panama disease, Fusarium wilt, Cavendish, epidemiology, soil, water, weeds, alternative host, sanitation by burning 


\section{Introduction}

Plant disease epidemiology is an important cornerstone of plant health (Cooke et al., 2006). Epidemiological data can be used to strategically plan and shape policy-decisions for an evidence-based management strategies. Agriculture is in continuous battle with new and recurrent epidemics (Fisher et al., 2012). A few example of plant disease epidemics to include the Irish potato famine pathogen caused by Phytophthora infestans (Bourke, 1964; Yoshida et al., 2013), the cassava mosaic virus in West Africa (Legg, 1999; Thresh and Cooter, 2005), Dutch elm disease caused by Ophiostoma novo-ulmi (Gibbs, 1978a; Gibbs, 1978b; Jones, 1981) and bacterium Xylella fastidiosa on olive trees (Almeida, 2016), underlining the international movement of planting material as source of pathogen dispersal. The impact of these plant diseases and losses compel for the multifaceted epidemiological investigation leading to cost-effective management strategies.

Banana, comprising sweet dessert and cooking bananas, is regarded as one of the most important crops (Aurore et al., 2009; Ploetz et al., 2003, Ploetz et al., 2015) with total annual production of 114 million tonnes (FAOSTAT, 2017). Asia accounts for $56 \%$ of the world production followed by $20 \%$ in South America, $10 \%$ in Central America and the remaining from Africa (FAOSTAT, 2014). The latter use banana as staple food crop for example in Uganda with daily consumption up to $1.6 \mathrm{~kg}$. per capita (Thornton and Cramer, 2012). The export trade of bananas is dominated by cv. Cavendish and estimated to comprise 20.5 million tonnes for 2017 with Ecuador, Guatemala, Costa Rica, Philippines, Colombia, Mexico, Dominican Republic and Peru as major exporters (FAOSTAT, 2017). Banana production and trade is important for the economy of the producing and exporting countries and also, source of income for people that are directly and indirectly involved with banana.

Pest and diseases compromise banana production worldwide (Blomme et al., 2013; Dita et al., 2013; Jones, 2002; Jones, 2009; Ploetz et al., 2015). The soil-borne Fusarium spp. causing Panama disease in banana enter the roots through natural openings or wounds, advance internally and eventually occlude the xylem vessels causing typical discolouration of the vascular system and chlorosis of the foliage of affected plants resulting in plant death (Diener, 2012; Di Pietro et al., 2003; Gou et al., 2014; Li et al., 2011; Ploetz, 2000; Stover 1962; Yadeta \& Thomma, 2013). These Fusarium spp. carry an historical legacy of a very destructive plant pathogens that pushed the Central American banana industry, based on the banana Gros Michel, to destruction in the previous century (Ploetz, 2015a; Stover, 1962; PerezVicente, 2004). This epidemic was quenched by growing Cavendish varieties that are highly resistant to the previously identified causative Fusarium spp. (Marquardt, 2001). However, F. odoratissimum, colloquially called Tropical race 4 (TR4), kills Cavendish and many other banana varieties (Garcia et al., 2019) and develops into a pandemic that threatens local and export markets and therefore many small holder livelihoods (Ploetz, 2015b). Initially, TR4 spread almost unnoticed, but after its occurrence outside Southeast Asia (Garcia et al., 2014; Ordóñez et al., 2015) more attention resulted in a range of confirmed incursions underscoring the difficulty to control the disease (Buddenhagen, 2009; Chittarath et al., 2017; Hung et al., 
2017; Li et al., 2013; Molina et al., 2009; Mostert et al., 2017; O'Neill et al., 2016; Ploetz et al., 2015; Zheng et al., 2018). The recent outbreaks in the middle East, Africa and the Indian subcontinent (García-Bastidas et al., 2014; Maymon et al., 2018; Ordóñez et al., 2016; Ordóñez et al., 2015; Ploetz et al., 2015b; Thangavelu et al., 2019) jeopardize food security and underscore the danger of TR4 expansion and its detection in the United Kingdom further emphasizes the versatility of its dissemination (Anonymous, 2018). and in Colombia (https:// www.sciencemag.org/news/2019/07/devastating-banana-disease-may-have-reached-latinamerica-could-drive-global-prices) further emphasizes the versatility of its dissemination. Genetic and forensic analyses clearly showed that TR4 is a single disseminating clone (Ordóñez et al, 2015). Evidently, these facts demand special attention and immediate action to slow down banana decline.

Though soil-borne, intra-and inter-continental dissemination of TR4 is remarkable (Ploetz, 2015a). Man has been regarded to play a significant role in the movement of planting material, rhizomes and suckers to disease-free areas (Marin et al., 1998; Ploetz, 2005; Ploetz, 2015a). Movement of contaminated soil was deemed for the spread of the pathogen but this has been taken into account minimally. Tracing population of TR4 in the naturally infested soil across different soil depths has been poorly addressed. Surface water movement was as well blamed for the rapid spread of Fusarium spp. (Su et al., 1986) but concrete scientific evidences is inadequate. Although underestimated, crop and associated weed species can potentially intensify the spread of Fusarium spp. (Dita et al., 2018). A number of reports proved the isolation of Fusarium spp. from the roots of several weed species. In Australia, an infestation of two weed species by Foc-ST4 was reported (Pittaway et al., 1999). In northern Australia, where TR4 is prevalent, monocotyledenous and dicotyledenous plant species were identified as alternative hosts of TR4 (Hennessy et al., 2005; Podovan et al., 2003). Su et al. (1986) listed four weed species in Taiwan that function as alternative host for Foc race 4 to perpetuate in the field, suggesting the importance of weed management in combating this disease. No reports from other Fusarium spp. infested countries have been recorded in this regard.

Compared to other banana diseases, Panama disease control gained little attention and hence there are not efficacious control options known (Pegg et al., 1996; Ploetz, 1990; Ploetz, 2006). The environmental trade-offs of soil disinfectants banned products such as methyl-bromide but other commercial chemical treatments are not available and hence disease control depends on management practices. Therefore, exclusion of the pathogen is the first, and only, line of defense. This requires well-organized monitoring, quarantine and eradication plans supported by adequate and rapid diagnostics. Clearly, this includes prohibiting movement of soil, potential contaminated planting materials, people, implements, animals and preventing water flow around cordoned infested areas. Across the world, such practices are not uniformly implemented and not taken up seriously and the eradication procedures greatly vary. Australia proactively deploys biosecurity measures in the TR4 affected areas implementing "come clean - go clean" from the infected farm to other banana producing areas (O'Neill et al., 2016; Australia Department of Agriculture and Water Resources). Following a TR4 outbreak in Israel in 2016 (Maymon et al., 2018), the infected 
plants were eradicated and irrigation facilities were terminated confining the entire infested area under strict supervision and surveillance (ProMusa, 2018). Nevertheless, in 2019 a number of new outbreaks were identified (National Plant Protection Organization of Israel, 2019). In the Philippines, biosecurity measures were strictly implemented by large-scale commercial plantations but hardly for small-scale farmers. Panama disease management mostly relies on chopping down infected plants, subsequent covering of the remains with rice hulls that are set on fire for slow release sanitation by heat. Alternatively, plants are left standing and are caged with corrugated iron for destruction by fast intense heat by burning wood and gas. However, neither of these practices has been supported by data on fungal, especially chlamydospores, survival in the soil and hence lack reliable statistics on efficacy. This is disturbing as the Philippines is one of the largest exporters of banana (FAOSTAT, 2016), and the crop (cooking or sweet dessert) is grown all over the archipelago with a total land area of around 450,000 ha (Philippine Statistics Authority, 2016) either in backyards for home consumption, mixed-crop and small-scale farming for local markets or large-scale monocrop commercial plantations. Since TR4 is omnipresent, the industry is constantly battling Panama disease. In the past, other Fusarium spp. (formerly indicated as vegetative compatibility groups (VCGs) 0122, 0123 and 0126, but now recognized as F. phialophorum, F. oxysporum and F. purpurascens, respectively; Maryani et al., 2019) devastated cv. Cavendish, Latundan and Lakatan bananas affecting 30,000 ha. from 1974 to 1991 (Magnaye, 2001 and Roperos and Magnaye, 1991). Also, the cooking banana variety Saba (syn. Cardaba) succumbed to Panama disease, but the first significant blow to the industry came after the incursion of TR4 in the early 2000s when commercial and smallscale Cavendish banana plantations in Mindanao were devastated (Molina et al., 2009; Mostert et al., 2017). From there, TR4 has disseminated across Mindanao and as a response banana companies relocate to new areas, which intensifies the spread of the disease, despite governmental and industrial awareness programs.

In this study, we use molecular diagnostics and traditional laboratory assays to better understand the epidemiology of TR4 in the Mindanao banana belt. The presence of TR4 was determined in soil at different depths prior and after executed management practices, such as burning, which was also used to test the efficacy of these treatments. Furthermore, we generated data on the dissemination by human trafficking and with surface water and determined the presence of TR4 in ubiquitous non-host weeds. Taken together, these data show a remarkable longevity of TR4 inoculum, which questions the overall efficacy of disease management practices. Evidently, this fuels grim scenarios of an almost unstoppable epidemic that threatens banana production in Mindanao and thereby affects the livelihoods of many smallholders.

\section{Materials and methods}

\section{DNA-based diagnostics for TR4}

In this study, DNA-based diagnostics were crucial to detect small amounts of TR4 in different matrices. The commercially available SYBR-green based qPCR (http://www.cleardetections. 
com/product2-type/foc-tr4-detection) was utilized to specifically detect TR4 in surface water following manufacturer's instructions. The developed LAMP TR4 diagnostics (Salacinas et al., 2019) was utilised for detecting TR4 in weeds and other plant species to test whether they can be alternate hosts for TR4 (Table 1, Chapter 2 this thesis).

Table 1. Primers and probes utilized in this study.

\begin{tabular}{|c|c|c|c|c|}
\hline Purpose & $\begin{array}{l}\text { Primer or } \\
\text { probe }\end{array}$ & Name & Oligonucleotide sequence $\left(5^{\prime}-3^{\prime}\right)$ & Reference \\
\hline \multirow[t]{8}{*}{ LAMP for TR4 } & \multirow[t]{8}{*}{ Primer } & F3 & AATAGTAAAGATGCTGAACTTCT & \multirow[t]{8}{*}{ This thesis (Chapter 2) } \\
\hline & & B3 & ACTCTTGTGAGAGGTCGA & \\
\hline & & \multirow[t]{2}{*}{ FIP } & TGGGAGGAAGAACTTTCTAGTAT- & \\
\hline & & & GAGAAAGGATAAGGGATGTAATGTTG & \\
\hline & & \multirow[t]{2}{*}{ BIP } & TTGCTCAATTTCCTTGTGTTTCG- & \\
\hline & & & CAGGATTCACGATAGTAGAGTT & \\
\hline & & Loop F & ACCAAAAGCCTAGGAGAGGATT & \\
\hline & & Loop B & TCTTCTTCTTCGCCGTACCTCATCA & \\
\hline \multirow{3}{*}{$\begin{array}{l}\text { TaqMan qPCR } \\
\text { for TR4 }\end{array}$} & \multirow[t]{2}{*}{ Primer } & Forward_175 & TCCGGTCTTTGAATCCCTTTC & \multirow[t]{2}{*}{ This study } \\
\hline & & Reserve_175 & CCATCACTGCAGCTTGTAAATATG & \\
\hline & Probe & PrTR4_175 & $\begin{array}{l}\text { 56-FAM/ TCTCCTGCT/ZEN/ } \\
\text { TGACTTGACAATATCCCA/3IABkFQ }\end{array}$ & This study \\
\hline \multirow{3}{*}{$\begin{array}{l}\text { TaqMan qPCR } \\
\text { for PLRV }\end{array}$} & \multirow[t]{2}{*}{ Primer } & IntCon_F & AAGAAGGCGAAGAAGGCAATCC & \multirow[t]{2}{*}{ Waalwijk et al., 2004} \\
\hline & & IntCon_R & GCACTGATCCTCAGAAGAATCG & \\
\hline & Probe & IntCon_P & $\begin{array}{l}56 \text { FAM/CGAAGACGC/ZEN/ } \\
\text { AGAAGAGGAGCCAAT/3IABkFQ }\end{array}$ & Waalwijk et al., 2004 \\
\hline
\end{tabular}

To avoid problems with inhibition of PCR reactions due to the presence of organic matter or humic acids in DNA preps from soil we developed a highly sensitive TaqMan probe-based qPCR assay based on the Seq5 TR4 unique sequence (see Chapter 2 this thesis; Table 1 ) using the PrimerQuest tool (Integrated DNA technologies, USA). The probes were labelled with ZEN / lowa Black FQ as double-quenchers. The specificity of the primers and probes were confirmed on genomic DNA samples from 24 genotypes of Fusarium spp. causing Panama disease in banana (Ordóñez et al., 2015; Maryani et al., 2019), 22 confirmed TR4 strains from different geographic locations and 18 other Fusarium spp. (see Chapter 2 this thesis). Amplifications were performed in an ABI 7500 real-time PCR system (Applied Biosystems, USA) in $15 \mu \mathrm{l}$ reaction volumes containing $5 \mu$ lemplate, $100 \mathrm{mM}$ of probe and $300 \mathrm{mM}$ of each forward and reverse primer and Premix Ex Taq master mix (Takara, Japan) and each reaction included a negative control with nuclease-free water instead of template DNA. PCR cycling was set at $95^{\circ} \mathrm{C}$ for 2 minutes, followed by 40 cycles of $95^{\circ} \mathrm{C}$ for 15 seconds and $60^{\circ} \mathrm{C}$ for one minute. Results were catalogued as cycle threshold $(\mathrm{Ct})$ values, which is the qPCR cycle at which the fluorescence exceeds a threshold value. A $C t$ value of $<37.5$ was regarded as a positive result by automated calculations using Detection 1.2 software (Applied Biosystems, USA) and final data comprised the average $\mathrm{Ct}$ value of four biological controls (independent DNA extractions of each soil sample). To determine the efficiency of DNA extraction and potential GPCR inhibition, we added $1 \mathrm{ng}$ of exogenous plasmid 
DNA from potato leaf roll virus (PLRV) to each sample, which was afterwards amplified in separate qPCR reactions. The PLRV primers and probe (Table 1) and the qPCR amplification conditions were adapted from Waalwijk et al. (2004).

\section{Tracing TR4 in soil and water}

In order to trace contamination of TR4 in soil, we visited small and large-scale commercial banana plantations planted with Cavendish, Lakatan and Cardaba bananas in Mindanao, Philippines (Figure 1, Table S1) between November 2014 and March 2015 and from July to December 2015. In every case, soil underneath banana plants showing Panama disease symptoms was collected from the top layer $(0-0.25 \mathrm{~m})$ at a distance of $1 \mathrm{~m}, 3 \mathrm{~m}, 5 \mathrm{~m}$ and $10 \mathrm{~m}$ from the infected plant using an auger that was disinfected between samplings. In some locations we also conducted vertical soil sampling at $0.25 \mathrm{~m}, 0.50 \mathrm{~m}, 0.75 \mathrm{~m}$ and $1.0 \mathrm{~m}$. For each horizontal and vertical sample, we collected four subsamples surrounding the symptomatic plant which were then pooled to form a composite sample per plant (Figure 1). These samples were homogenized in the field and representative sub-samples were collected in sterile $50 \mathrm{ml}$ plastic tubes that were subsequently placed in a laminar flow hood in the laboratory for overnight drying. Additionally, we collected soil from footwear after walking in Panama disease infested banana plantations in Mindanao, Philippines (2015) and China (2015 and 2016) (Figure S2). We used a KingFisher ${ }^{\text {tm }}$ Magnetic Particle Processor (Thermo Fisher Scientific, USA) following the manufacturer's protocol with slight modifications enabling high-throughput parallel DNA extractions of large numbers of soil samples. For each sample, four independent DNA extractions were conducted using 0.25 grams of soil in a 96-well format using a MoBio PowerMag soil DNA extraction kit (MoBio Laboratories, USA). Each sample was complemented with an internal PLRV plasmid DNA control well before cell lysis by bead beating and every 96-well extraction plate contained triplicated positive controls $\left(10^{3}\right.$ chlamydospores. gram $^{-1}$ of soil) and negative controls (twice autoclaved non-infested soil). Extracted DNA was eluted in $100 \mu$ l elution buffer (MoBio Laboratories, USA) and used as template for TaqMan probe-based qPCR.

Surface water contamination was monitored from 2013 to 2016 in a commercial Cavendish banana plantation in Mindanao, Philippines. We sampled eight rivers, one creek and three reservoirs situated within or neighbouring the Cavendish banana plantation at monthly intervals and collected three composite samples (each $50 \mathrm{ml}$ ) $50 \mathrm{~m}$ from the edge of the water system at each site. In the laboratory, the samples were immediately split for direct DNA extraction and viability plating and then processed by removing debris by 1 hour sedimentation and subsequent filtering using a vacuum set-up (Sartorius AG, Germany) with a cellulose Millipore filter (Merck Millipore, Germany) with a pore size of $0.45 \mu \mathrm{m}$. For direct DNA extraction, the filter was placed in a $5 \mathrm{ml}$ tube with $1.5 \mathrm{ml}$ MilliQ water and 1.5 grams of $500 \mu \mathrm{m}$ glass beads (Sigma-Aldrich, USA), which was vortexed (Genie 2, Scientific Industries, USA) at maximum speed for 15 minutes. The resulting lysate was diluted (20x) and used as template for TR4 detection using a commercial diagnostic kit (ClearDetections, The Netherlands, Wageningen). For viability plating, we placed the filter in a Komada 
plate amended with $100 \mathrm{mg} \cdot \mathrm{L}^{-1}$ streptomycin, which was incubated for three days at room temperature $\left( \pm 27^{\circ} \mathrm{C}\right)$. Developing colonies were collected and processed by placing them in a $2 \mathrm{ml}$ tube with $1 \mathrm{ml}$ MilliQ water and subsequent analyses with the ClearDetections TR4 diagnostic kit.

\section{Validating the efficacy of rice hull burning as a field sanitation method}

Rice hull burning is a commonly practiced strategy for TR4 management in Mindanao. We conducted two open-field burning experiments in a naturally TR4 infested commercial Cavendish banana plantation to determine the temperature profile during burning at different soil depths and to evaluate the efficacy of this management strategy. The first experiment was rice hull burning using 30 bags of rice hull (approximately $15 \mathrm{~kg}$ per bag) (Figure S1). The second experiment we used wood arranged vertically surrounding the chopped infected plant and then supplemented with gas to start the fire (Figure S1). As the fire produced is quick relative to rice hull burning, second burning was done the day after using only gas to burn into ashes the remaining plant tissue. Soil temperatures were monitored by placing two fiberglass-insulated thermocouples attached to a data logger (Delta-T, UK) at the surface and $0.1,0.2$ and $0.4 \mathrm{~m}$ depth. The sensors operate until $1000^{\circ} \mathrm{C}$ with an accuracy of $\pm 1{ }^{\circ} \mathrm{C}$ and the data loggers were programmed to collect data every minute during the duration of the experiments. Three days after the initiation of the experiments the data loggers were recovered and data were downloaded. In both experiments, we placed heat resistant mesh bags with $1.10^{7}$ chlamydospores.gram ${ }^{-1}$ soil randomly around $(0.3 \mathrm{~m})$ an infected plant at $0.10,0.20,0.40$ and $1 \mathrm{~m}$ depths and a similar lay-out was used to collect control samples outside the treated area ( $3 \mathrm{~m}$ from the infected plant). After two weeks (rice hull burning) and one week (wood burning) the mesh bags were collected, and the content was used in viability tests as described above to test the survival of chlamydospores. In addition, we randomly sampled soil at depths of $0.25 \mathrm{~m}, 0.50 \mathrm{~m}, 0.75 \mathrm{~m}$ and $1.0 \mathrm{~m}$ prior and after rice hull burning. Compound samples were prepared for each distance and taken to the laboratory for DNA extraction and TaqMan probe-based GPCR analyses as described above.

\section{Alternative hosts of TR4}

To better understand the epidemiology of TR4, we also sampled weed plant species in a banana farm with no Panama disease incidence ( North $7 \circ 28^{\prime} 18^{\prime \prime}$ East $125 \circ 35^{\prime} 55^{\prime \prime}$ ), a banana

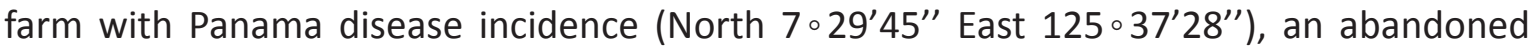
banana farm and currently cropped to maize (North $7 \circ 33^{\prime} 16^{\prime \prime}$ East $125 \circ 42^{\prime} 49^{\prime \prime}$ ), an abandoned banana farm currently cropped to pineapple (North $7 \circ 11^{\prime} 38^{\prime \prime}$ East $125 \circ 23^{\prime} 24^{\prime \prime}$ ) and a backyard farm cropped with coconut (North 7 ${ }^{\circ} 18^{\prime} 22^{\prime \prime}$ East $125 \circ 41^{\prime} 40^{\prime \prime}$ ). The collected species were taxonomically identified following Moody et al. (2014). All abandoned farms were planted to other crops due to severe Panama disease infestations that disabled banana production. Sampling was conducted from October 2015 to March 2016. Healthy and symptomless plants were uprooted, loose soil was removed and in the laboratory each plant was washed with distilled water and the aboveground parts were cut or segmented 
and surface sterilized with $70 \%$ ethyl alcohol for one minute, rinsed again with distilled water, then placed on Komada medium in $9 \mathrm{~cm}$ Petri dishes and incubated for five days at room temperature $\left( \pm 27^{\circ} \mathrm{C}\right)$. Mycelial colonies similar to Fusarium spp. were transferred to fresh Komada (Komada, 1975) plates for three days at room temperature $\left( \pm 27^{\circ} \mathrm{C}\right)$ and then collected and processed using the above described TR4 LAMP assay.

\section{Results}

\section{Spatial distribution of TR4 in banana soils}

A total of 312 soil samples was analysed from seven provinces in Mindanao, Philippines (Figure 1, Table S1), which are prime for small and large-scale banana production for local consumption or the export trade. We determined TR4 presence in all samples, except for Cardaba plantations (Table S1) in Davao del Sur, which is likely due to the small sample size. Sites with a reported high prevalence of Panama disease for both Cavendish or Lakatan (Figure 1), indeed showed TR4 dissemination across vertically sampled across soil layers until $1 \mathrm{~m}$. The qPCR analyses on the samples and controls indicated that no inhibition of the TR4 target DNA amplification was detected. The concentration of determined TR4 inoculum in the sampled soils was always much lower than the positive control $\left(1.10^{3}\right.$ chlamydospores. $\left.\mathrm{gram}^{-1}\right)$. The soil samples collected from footwear were positive for the presence of TR4 both used in the Philippines and in China (Figure S2). Taken together, these data substantiate the notion that TR4 is omnipresent in infested plantations.

\section{Surface water contains TR4}

We collected 352 water samples from the 12 sites for three years. Five samples from four sites were positive for TR4. Three of those were confirmed by PCR and two by viability plating (Table S2). Two of the sites (\#4 and \#9) were rivers bordering or crossing the plantation, respectively, while the others (\#1 and \#3) were reservoirs situated at the border of the farm that sourced their content from the bordering river (\#4). TR4 was detected in two consecutive years (2014 and 2015) at site \#1, whereas the other sites were positively tested once. We conclude that surface water, particularly irrigation water, can be a potential source of inoculum for further spread TR4 in disease free areas. 
A
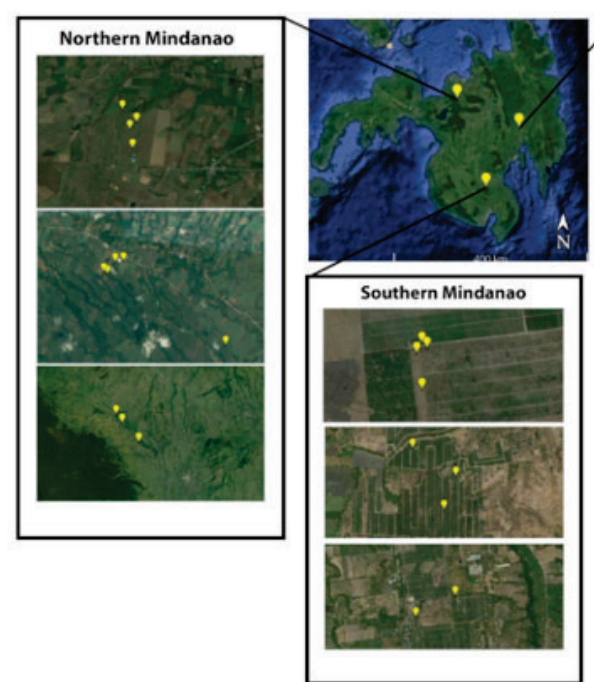

C

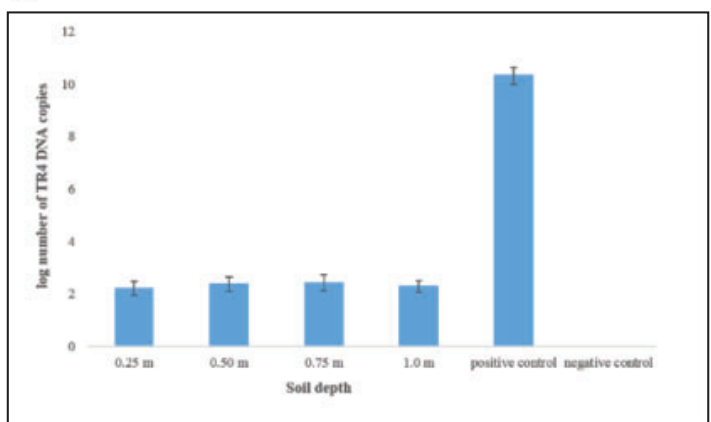

B

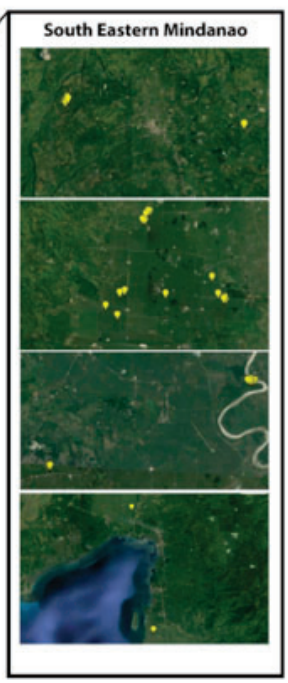

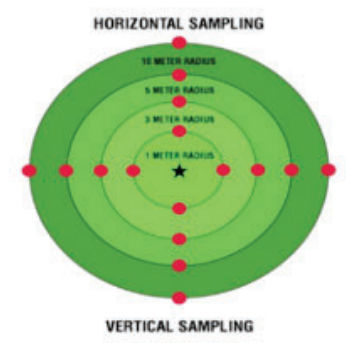

VERTICAL SAMPLING

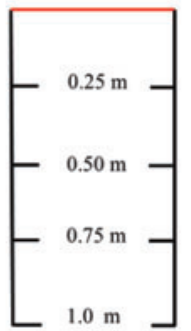

D

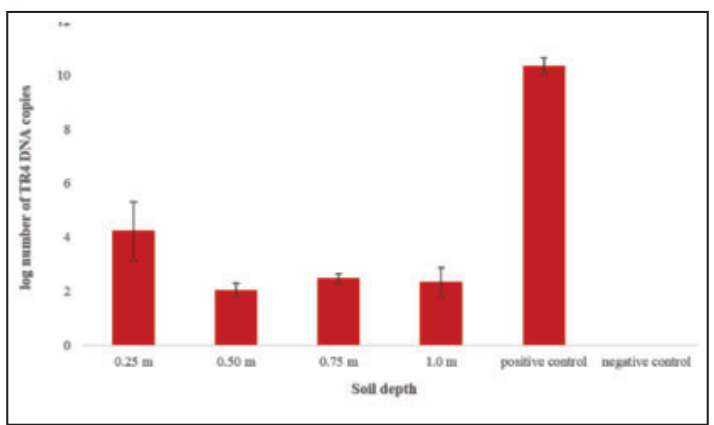

Figure 1. Tracing Panama disease in the Philippines. Soil sampling sites for tracing Fusarium odoratissimum Tropical Race 4 (TR4) infestation of small and large scale banana plantations in Mindanao, Philippines (A). The sampling strategy is based on horizontal and vertical mapping of TR4 in soil attached to and surrounding an infected banana plant (B). Quantitative vertical mapping of TR4 in fields planted to Grand Naine (AAA) (C) or Lakatan (AA) (D). The positive control is a Dutch soil artificially infested with TR4 chlamydospores at a rate of $10^{3}$ chlamydospores.gram of soil-1 as determined by plate dilution technique. The negative control is the same uninfested soil, autoclaved twice. 


\section{Burning does not eradicate TR4 inoculum in soil}

Since field sanitation by burning (Figure S1) is a common part of the TR4 management strategy in Mindanao, but its efficacy especially on infested soil is unknown. During these practices we determined the temperature profiles (Figure 2) that revealed a maximum peak of surface temperature of $350^{\circ} \mathrm{C}$ and $113^{\circ} \mathrm{C}$ on the first and second day of rice hull burning, respectively. Subsequently, temperatures dropped over time and with depth as we measured maximum temperatures at $0.10,0.20$ and $0.40 \mathrm{~m}$ depth of $57^{\circ} \mathrm{C}, 50^{\circ} \mathrm{C}$ and $36^{\circ} \mathrm{C}$, respectively (Figure 2). For wood burning, we recorded two surface temperature peaks of $363^{\circ} \mathrm{C}$ and $737^{\circ} \mathrm{C}$ at first and second day of the treatment, respectively, when intense fire was produced, but in between these peaks temperature dropped to less than $100^{\circ} \mathrm{C}$ (Figure 2). The second wood burning peaked at $344^{\circ} \mathrm{C}$ on day two and dropped to $130^{\circ} \mathrm{C}$ until the measurement ended (Figure 2). Indeed, in general wood burning caused higher temperatures across the soil profile which peaked at day 1 at sub-surface depths of 0.10 $\mathrm{m} 396^{\circ} \mathrm{C}$, of $0.20 \mathrm{~m}$ at $52^{\circ} \mathrm{C}$ and of $0.40 \mathrm{~m}$ at $36^{\circ} \mathrm{C}$. On the second day of this treatment the temperatures at subsurface depths of $0.10 \mathrm{~cm}, 0.20 \mathrm{~cm}$ and $0.40 \mathrm{~cm}$ were $368^{\circ} \mathrm{C}, 145^{\circ} \mathrm{C}$ and $105^{\circ} \mathrm{C}$, respectively (Figure 2 ).

We expected to detect TR4 prior to burning, but despite the high temperatures across the soil profiles, we still detected TR4 after rice hull burning at every depth after rice hull burning and chlamydospores survived in the mesh bags at a depth of $1 \mathrm{~m}$ irrespective of the used burning method (Figure 3). The difference of TR4 quantity between the untreated controls in the laboratory and the field indicate that sub-surface placement of mesh bags slightly affects the viability of the chlamydospores at different soil depth (Figure 3). After rice hull burning the TR4 quantity in the top soil is significantly reduced, suggesting degradation of DNA or death of chlamydospores, but increased at depths of $0.50 \mathrm{~m}, 0.75 \mathrm{~m}$ and $1 \mathrm{~m}$. These data show the limited efficacy of field sanitation by burning.

\section{TR4 is an endophyte of other plant species in banana plantations}

We identified eight commonly observed weeds, belonging to seven botanical families, as hosts of TR4 in at least one occasion (Table 2, Figure S3). However, none of these species showed wilting symptoms collected either from existing banana farms, backyard farms with coconut and an abandoned banana plantation currently planted to maize or pineapple. Majority of these weed species tested positive for TR4 were collected from abandoned farm due to Panama disease except for Echinochloa colona (Table 2). This weed species was sampled from existing banana farm with Panama disease infestation which accords with the observed TR4 presence in the soil of this plantation (Table S1). These data show that TR4 can survive in non-host plants. 
Chapter 3
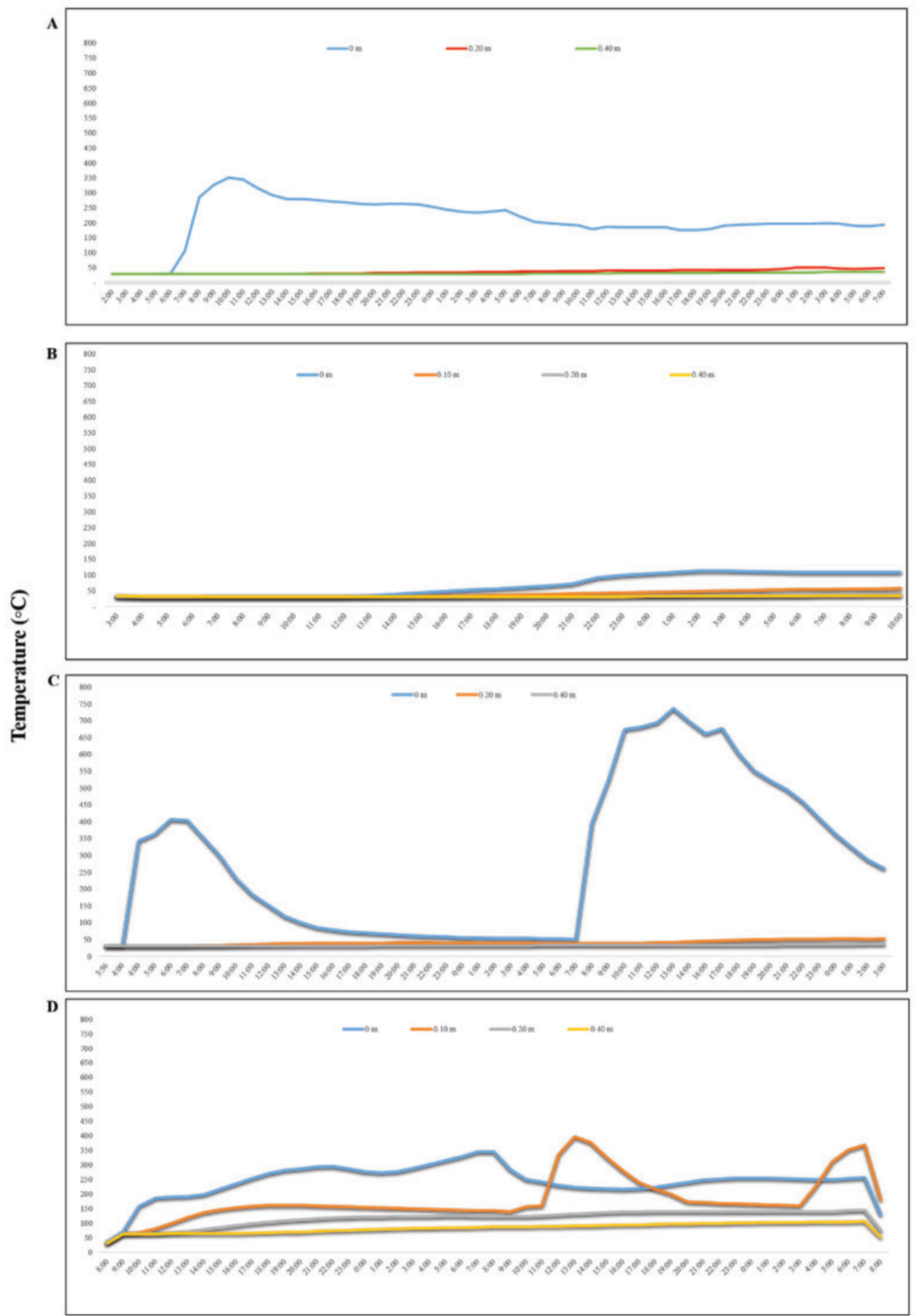

Time (hour)

Figure 2. In-field sanitation of Panama disease in the Philippines. Temperature profiles at different soil depths during replicated rice hull burning $(A, B)$ and wood burning $(C, D)$ sessions, monitored using thermocouples with attached data loggers. The plotted temperatures are hourly averages based on four readings per minute. The trials were conducted in a commercial Cavendish banana plantation in Mindanao, Philippines. 


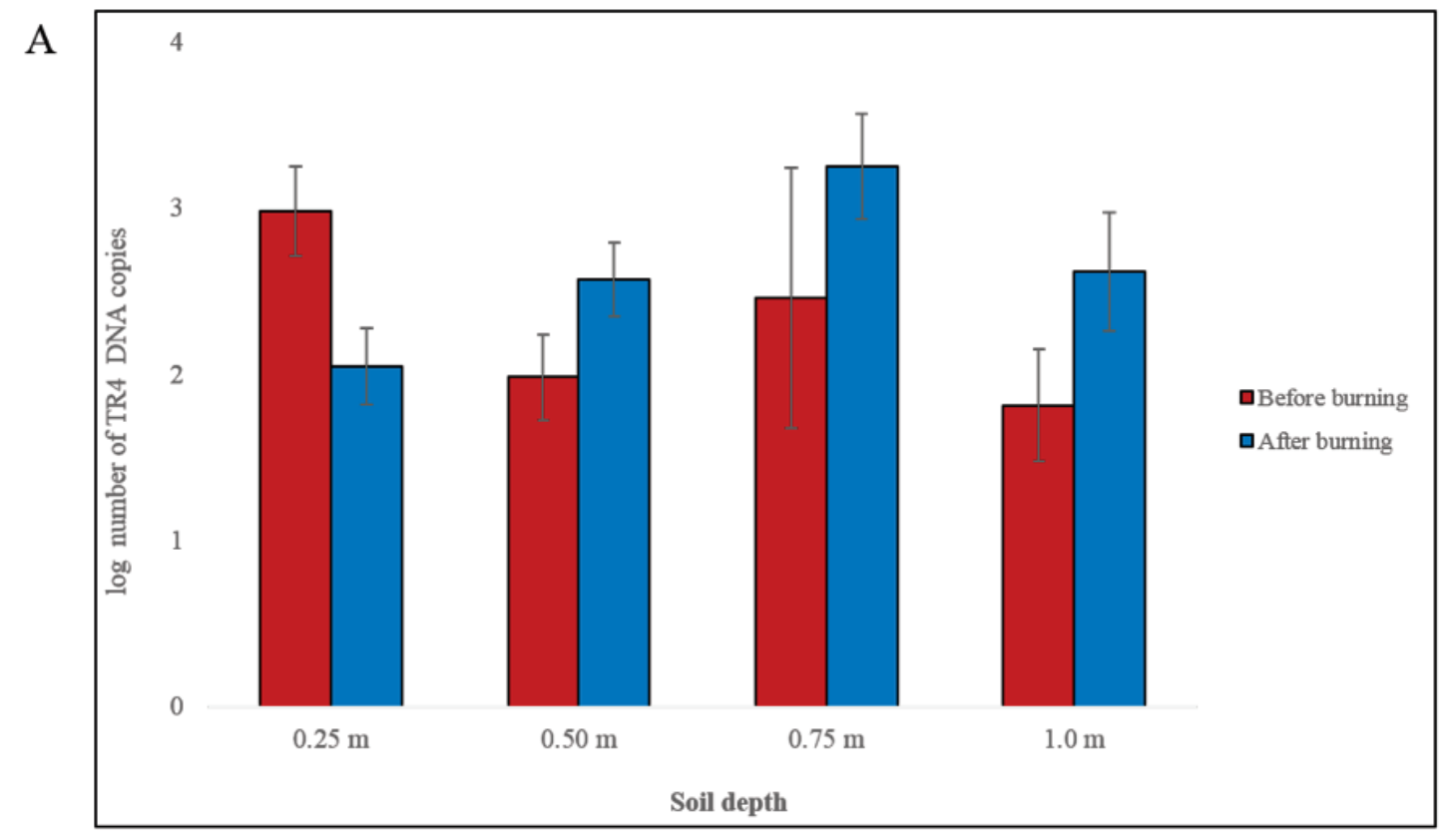

B

\begin{tabular}{|c|c|c|c|c|}
\hline \multirow{2}{*}{ Treatment } & \multicolumn{4}{|c|}{ log viable TR4 chlamydospores ${ }^{a}$} \\
\hline & $0.10 \mathrm{~m}$ & $0.20 \mathrm{~m}$ & $0.40 \mathrm{~m}$ & $1.0 \mathrm{~m}$ \\
\hline laboratory control, nonburned ${ }^{b}$ & 7.53 & 7.53 & 7.53 & 7.53 \\
\hline field control, nonburned ${ }^{c}$ & 6.90 & 6.84 & 7.08 & 7.27 \\
\hline field, ricehull burned & 0 & 0 & 0 & 7.38 \\
\hline field, wood burned & 0 & 0 & 0 & 7.23 \\
\hline
\end{tabular}

Figure 3. Quantifying the efficacy of sanitation techniques on Fusarium odoratissimum Tropical Race 4 (TR4) inoculum in soil. The effect of rice hull burning on TR4 quantities at different depths in a naturally infested field as determined by qPCR (A) and the effect of rice hull or wood burning on the survival of known quantities of TR4 in test samples $\left(10^{7}\right.$ chlamydospores.gram of soil $\left.{ }^{-1}\right)$ that were submerged in sites where burning was used as an in-field sanitation method (B). 
Chapter 3

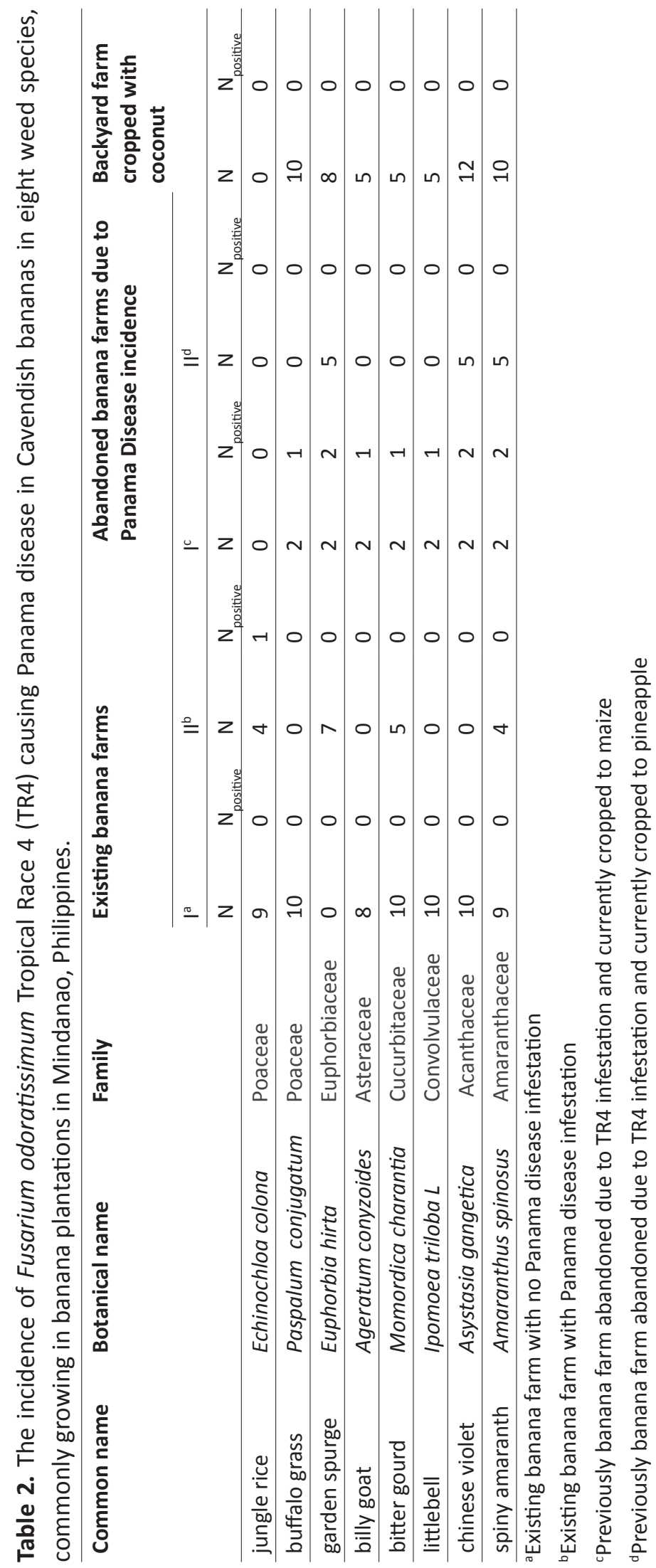




\section{Discussion}

Plant diseases threaten crop production world-wide and reduced sensitivity to crop protection agents is a growing concern (Fisher et al., 2018; Bebber et al., 2014). Intensified global trafficking also contributes to the dissemination of pathogens (Almeida, 2016). The rapid decline of amphibians was reported and is due to the occurrence of new fungal species and dissemination of known species to new areas, where they threaten biodiversity (Fisher et al., 2012; Stuart et al., 2004). Panama disease epidemics are not new to banana. In the previous century Fusarium spp. decimated the Gros Michel based industry in Central America (Marquardt, 2001; Soluri, 2002). Before the industry embraced the cultivation of Cavendish banana as the solution for this problem, manifold control measures were tested, but essentially failed (Marquardt, 2001). The current Panama disease epidemic in Cavendish that is caused by the new species F. odoratissimum - commonly known as TR4 - started in the late 1960s and has currently evolved to a nearly pandemic disease and is a reminiscence of this previous epidemic (Maryani et al., 2019). This species entered the Philippines and was discovered in early 2000s (Molina et al., 2009). Since then, it has spread across the Mindanao banana belt and caused havoc among small holder and industrial plantations. This contributed to a wide variety of measures to control the disease, including the planting of Cavendish mutants with reduced susceptibility, the so-called Giant Cavendish Tissue Culture Variants or GCTCV clones (Hwang et al., 2004), and various practices to reduce the soil-borne inoculum, such as rice hull burning. Eventually, however, these measures are insufficient resulting in the abandonment of farms and relocation to disease-free areas in Mindanao and all other areas where TR4 not has surfaced (Zheng et al., 2018). Neither of currently applied measures has stopped the epidemic and this also underscores the need for addressing the unknown epidemiological phenomena that underlie the dissemination of TR4.

Our results show that soil attached to footwear was positive for the presence of TR4 in all tested occasions from the Philippines and China. Although the diagnostics employed was based on TaqMan qPCR and will not discriminate dead or alive chlamydospores. Along with the minimal efficacy of disinfectants on soil-borne TR4 inoculum (Salacinas et al., 2019) and the proven international dissemination of the pathogen (Zhang et al., 2018), this underscores the need to first clean and then disinfect tools, footwear and farm vehicles as widely implemented in Australia. Given the importance of chlamydospores survival in soil, field sanitation by burning is commonly practiced in Mindanao despite the fact that the efficacy in soil is unknown. Our data show that the inoculum load in treated soil is significantly lower than our controls, and yet is apparently sufficient to effectively disseminate the disease. The applied field sanitation by burning does indeed induce high temperatures in the top soil and for wood burning on deeper soil layers. However, these practices do not totally eradicate TR4 inoculum. At most they reduce the inoculum load in the top soil, whereas inoculum at deeper layers survives. Indeed, the lateral transfer of heat in soil is affected by soil moisture and soil texture (Frandsen and Ryan, 1986; Busse et al., 2005). Moreover, we showed that the temperature during burning is fluctuating between replicate burns. 
This is rather common (Preisler et al., 2000; Busse et al., 2005), and can be due to the amount of initial fuel loads, soil moisture contents, weather conditions and even soil physical properties (Ghuman and Lal, 1989; Busse et al., 2005). The spatial variation of temperature in treated sites might result in partial sterilization of soil hence, partial killing of target organism. Thus, although burning can potentially reduce TR4 inoculum, it has also negative effects due to harmful loss of nutrient capital and important soil microbiota (Neary et al., 1999). High temperatures can volatilize nitrogen between $200^{\circ} \mathrm{C}$ and $400^{\circ} \mathrm{C}$ and calcium and magnesium above $1000^{\circ} \mathrm{C}$ (Hungerford et al., 1991). Also, soil organic matter will vanish at approximately $200^{\circ} \mathrm{C}$ (Neary et al., 1999). To further the analysis of temperature effects on soil borne inoculum additional studies are required involving time lapse experiments on known amounts of soil and inoculum to identify the efficacy thresholds.

Our study is based on naturally infested soils planted to cv. Cavendish and Lakatan bananas in the Philippines and demonstrates that TR4 is present up to $1 \mathrm{~m}$ soil depth. The high inoculum density in top soils can be accounted for by the sporulation and accumulation of TR4 propagules as the plants are heavily infested evident in the wilting of the entire leaves. Banihashemi and de Zeeuw (1975) showed that F. oxysporum f.sp. melonis (Fom) inoculum was 20 times higher around wilted plants than non-wilted plants and also demonstrated that the concentration in the top soil $(0-2.5 \mathrm{~cm})$ was higher than in the subsurface layer of up to $20 \mathrm{~cm}$ depth. The presence of TR4 in the deep soil layer $(1 \mathrm{~m})$ is probably the result of the sporulation in the roots (root-to-root contact). Hence, eradication of TR4 from soils requires a more robust strategy that also reaches deeper soil layers. However, the majority of these TR4 contaminated soils were in commercial banana plantations of small holders that do not have enough resources to implement strict quarantine measures. As discussed above, our results also indicated that large scale plantations that stringently deploy biosecurity measures by installing footwear and tire baths (see Chapter 5 this thesis) at the entry and exit points should reconsider these strategies. A "come clean - go clean" strategy as implemented in Australia is in accord with our findings that disinfectants have a significantly reduced efficacy on soil borne TR4 inoculum. Relocating banana farms should go hand-in-hand with adequate risk assessment based on the presence of TR4 and the potential incursions from adjacent areas such as rivers, irrigation water and traffic. The inoculum loads in the tested soils was significantly lower than our controls and raises questions on the soil dose-response relationships for different environments, which may contribute to disruptive epidemics in one region, but mild epidemics in others. For club root caused by Plasmodiophora brassicae it was deduced that 1000 spores/gram dry soil is enough for symptom development (Faggian and Strelkov, 2009). This has been documented for other Fusarium spp., including F. oxysporum f.sp. ciceris (Navas-Cortes et al., 2007), F. culmorum and F. pseudograminearum in cereals (Hollaway et al., 2013), F. avenaceum on lentils (Hwang et al., 1994) and canola (Zhou et al., 2014) and F. oxysporum f.sp. lycopersici (Huang et al., 2016).

Taken together, we conclude that TR4 is distributed across soil layers which minimizes the impact of rice hull burning and wood burning. These strategies are essentially not optimal 
and should be reconsidered as a mean to stop TR4 dissemination across farms and adjacent areas.

Our study also showed that surface water is a source of TR4 dissemination. Hence, watershed is an important factor in developing overall TR4 disease management strategies. In this study, we sampled surface water utilized as source for irrigation delivered from rivers, creeks and reservoirs crossing and adjoining the banana plantation. We determined TR4 in two rivers and two reservoirs fed by the contaminated river. The origin of TR4 in these rivers and reservoirs is unknown but likely originates from run-off soil contaminations from nearby infested banana farms after heavy rains during the typhoon season in the Philippines. We identified five positive TR4 samples among 352 samples and hence, the rivers in this particular farm were not used anymore as source for irrigation and the reservoirs were drained and disinfected. Henceforward, irrigation water is now being sourced from deep wells as a safer option. This contributes to a better management of TR4. However, such solutions are impossible for many small holders and hence TR4 contaminated surface and irrigation water is a continuous concern for the Mindanao banana industry particularly during the summer season (March-May) when the need for irrigating banana farms is high. Our sampling was based on a monthly inspections that can be intensified to obtain a more realistic assessment of TR4 contamination. We also did not address the survival of TR4 inoculum in water and the effect of the water temperature on chlamydospores viability, which would be required for a better appraisal of TR4 dissemination by water (Erwin et al., 1983).

Finally, we considered that long term survival of TR4 might also be due to the endophytic presence in non-host weeds, particularly since various Fusarium spp. are omnipresent and known for their broad host range (Edel-Hermann and Lecomte, 2019). Such weeds can be present during cropping or act as a "green bridge" during a fallow period and absence of the host weeds and banana infecting Fusarium spp. were reported in weeds in Australia (Hennessy et al., 2005) and Taiwan (Su et al.,1986). We report it for the first time in the Philippines, and identified eight weed species from seven botanical families. The Asteraceae, Poaceae and Euphorbiaceae families were identified as putative weed hosts in our study and the aforementioned studies in Australia and Taiwan. In the past, Waite and Dunlap (1953) suggested that Commelina diffusa in Panama disease infested areas might be a carrier of the pathogen. In the previous studies Fusarium spp. were isolated from the roots of the weed species, but we confirmed the colonization of TR4 throughout the identified weeds. The pathogen may colonize these weeds as weak pathogen, but likely as an endophyte as we observed no wilting symptoms and plants were morphologically similar to those that were negative for the presence of TR4. Other Fusarium spp. heavily colonized the roots of the alternative hosts, but did not sporulate and consequently did not build-up inoculum in the rhizosphere (Banihashemi and de Zeeuw, 1975), but this was not verified in our study. Aside from chickpea, F. oxysporum f.sp. ciceris infects roots of grain legumes species such as bean, faba bean, lentil, pea and pigeon pea and various dicotyledonous weeds without manifesting external symptoms (Jimenez-Diaz, et al., 2015). Clearly, colonization of nonhost plants increases the survival potential of TR4 in the absence of susceptible banana 
plants (Hennessy et al., 2005; Pittaway et al., 1999). These weeds may act as reservoirs in the lateral transmission of TR4 in the uninfected areas even across continents (Jones and Diekmann, 2000; Perez-Vicente, 2004), suggesting the importance of weed management in combating Panama disease. Besides, there is also an indication that banana infecting Fusarium spp. can also infect commercially important ornamental plants belonging to order Zingiberales and Alismatales (Waman, et al., 2013). We will further address the role of weeds in the epidemiology of TR4 by determining the pathogenicity of the recovered strains on Cavendish and other varieties of banana. This will also include host range studies of TR4 as it touches principal aspects of pathogenicity swaps on host and non-host plants, which is of fundamental interest.

In conclusion, we consider that the presented data helps to better understand the epidemiology of TR4 and substantiate the critical evaluation of applied management strategies. We have addressed the distribution of TR4 propagules across soil profiles, their dissemination through contaminated soil particles and water, survival in weeds and the inadequacy of field sanitation by different burning strategies. Hence, our results call for an integrated and much more robust and data driven disease management to reduce the dissemination and impact of TR4. Clearly, these strategies should be back by governmental regulations and increased responsibility of all stakeholders as the regional and international impact of TR4 is driven by large scale mono-cropping. History has shown that any control measure is deemed to fail without addressing genetic uniformity of the crop.

\section{Acknowledgement}

This research was supported by funds from the Wageningen University Interdisciplinary Research Fund (INREF) program (www.panamadisease.org) and the Dioraphte Foundation, the Netherlands (GHJK, HJGM). We are indebted to the group of Euberto Catayas (Technical department, Tadeco Inc., Philippines) and Allieh Barriga (Plant Pathology department, Tadeco Inc., Philippines) for their help in the burning trial. The collaborating companies in the Philippines - Tadeco Inc., Nader Ebrahim s/o Hassan Inc. and Unifrutti Tropical Philippines Inc. are acknowledged for their valuable support in the field sampling and burning trial. 
$\mathbf{A}$

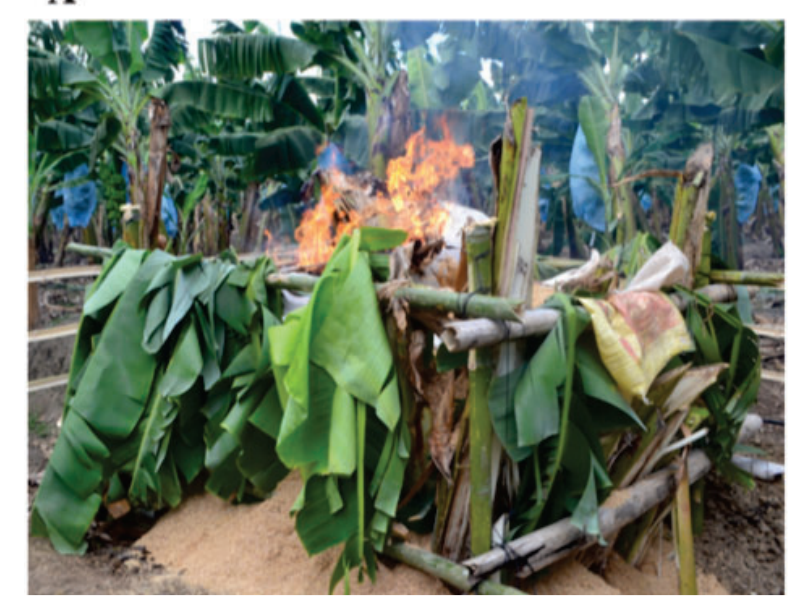

B

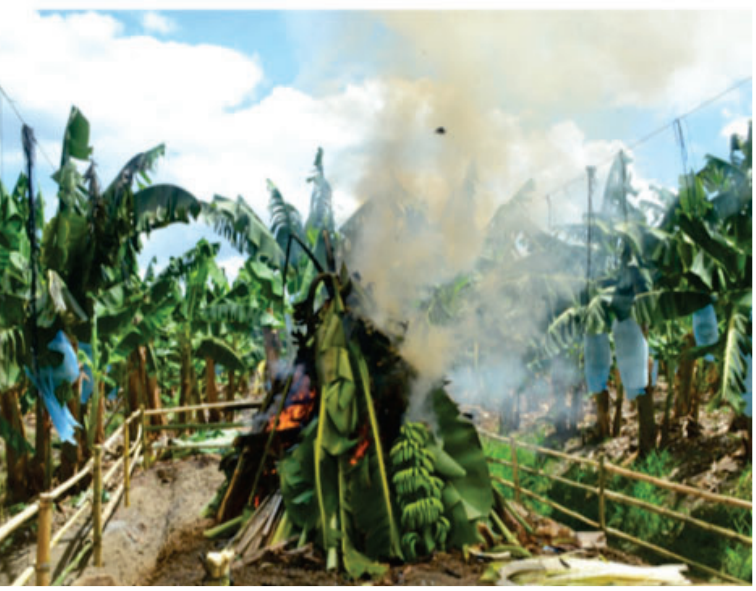

Figure S1. Practicing in-field sanitation of Panama disease in banana caused by Fusarium odoratissimum Tropical Race 4 (TR4) in the Philippines. Rice hull burning (A) and wood burning (B). 

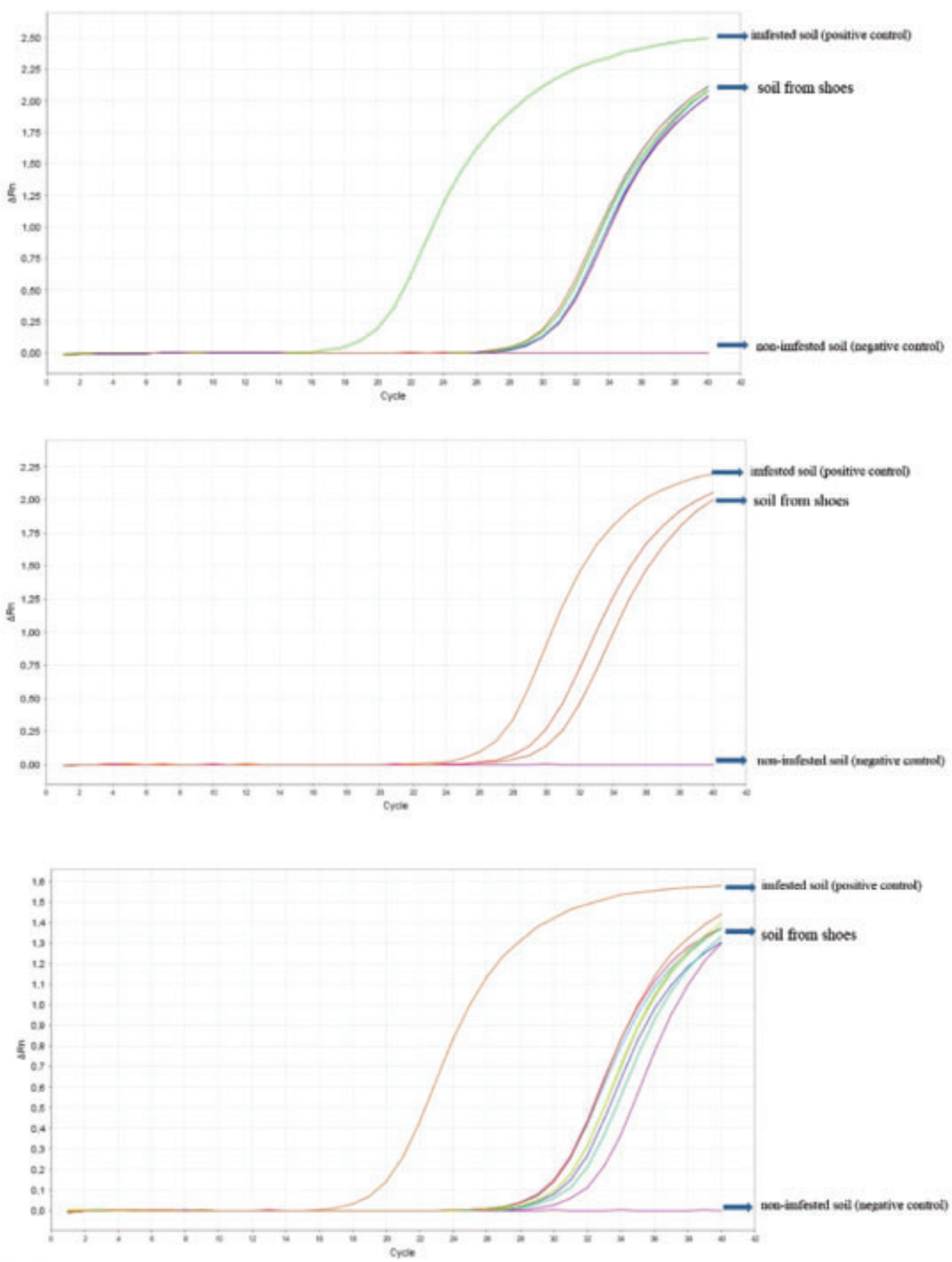

Figure S2. Disseminating Fusarium odoratissimum Tropical Race 4 (TR4). Quantitative detection of TR4 in soil attached to footwear used at TR4 infested farms in the Philippines in 2015 (A) and China in 2015 (B) and 2016 (C). Dutch uninfested soil spiked with TR4 chlamydospores ( $10^{3}$ chlamydospores.gram of soil $\left.^{-1}\right)$ was used as positive control and a twice autoclaved $\left(121^{\circ} \mathrm{C}\right)$ sample of the same uninfested soil was used as negative control. 

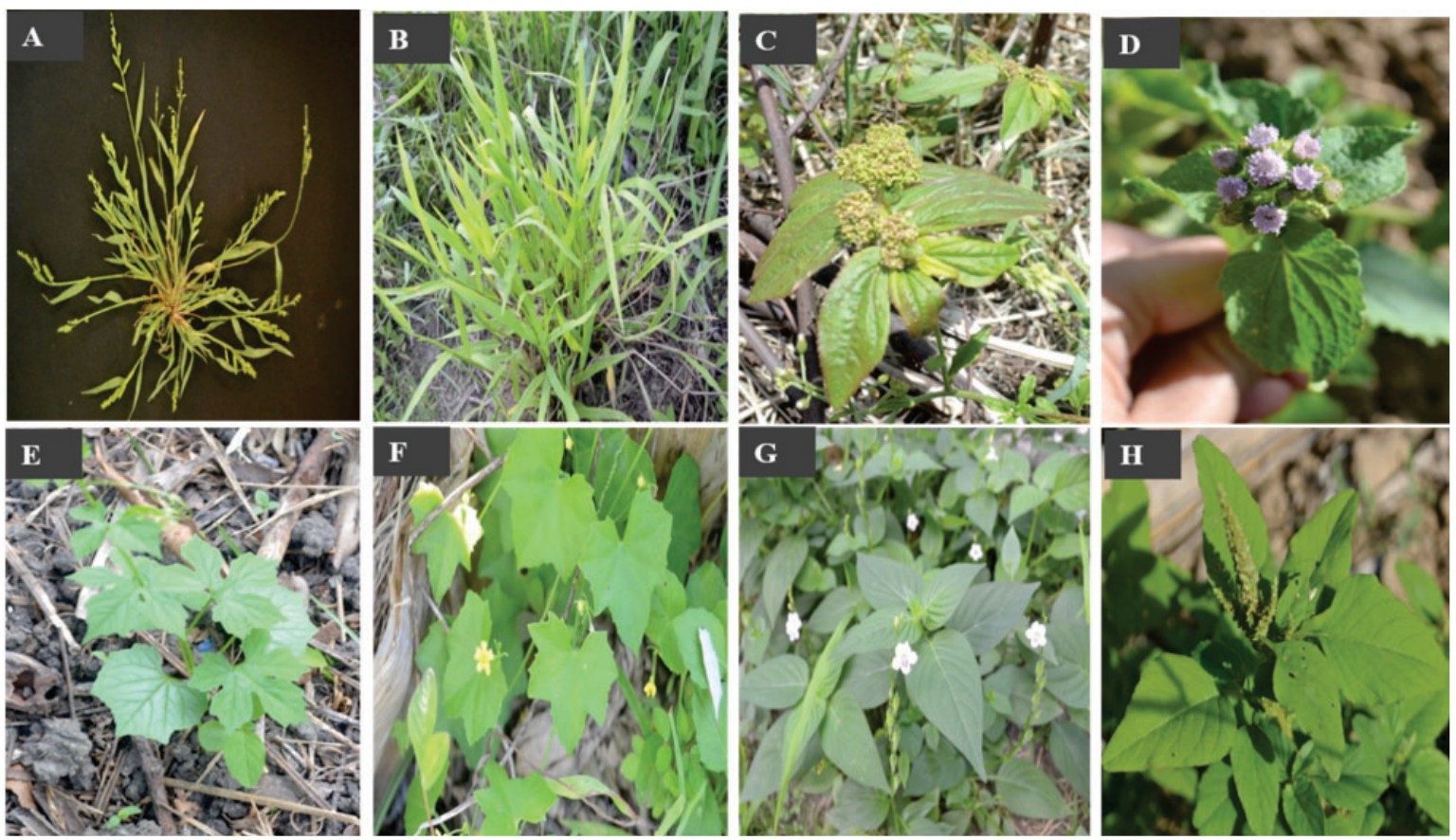

Figure S3. Weed species collected at Philippine banana farms in Mindanao were identified as alternative hosts of Fusarium odoratissimum Tropical Race 4 (TR4). (A) Echinochloa colona, (B) Paspalum conjugatum, (C) Euphorbia hirta, (D) Ageratum conyzoides, (E) Momordica charantia, (F) Ipomoea triloba L, (G) Asystasia gangetica, and (H) Amaranthus spinosus. 
Chapter 3

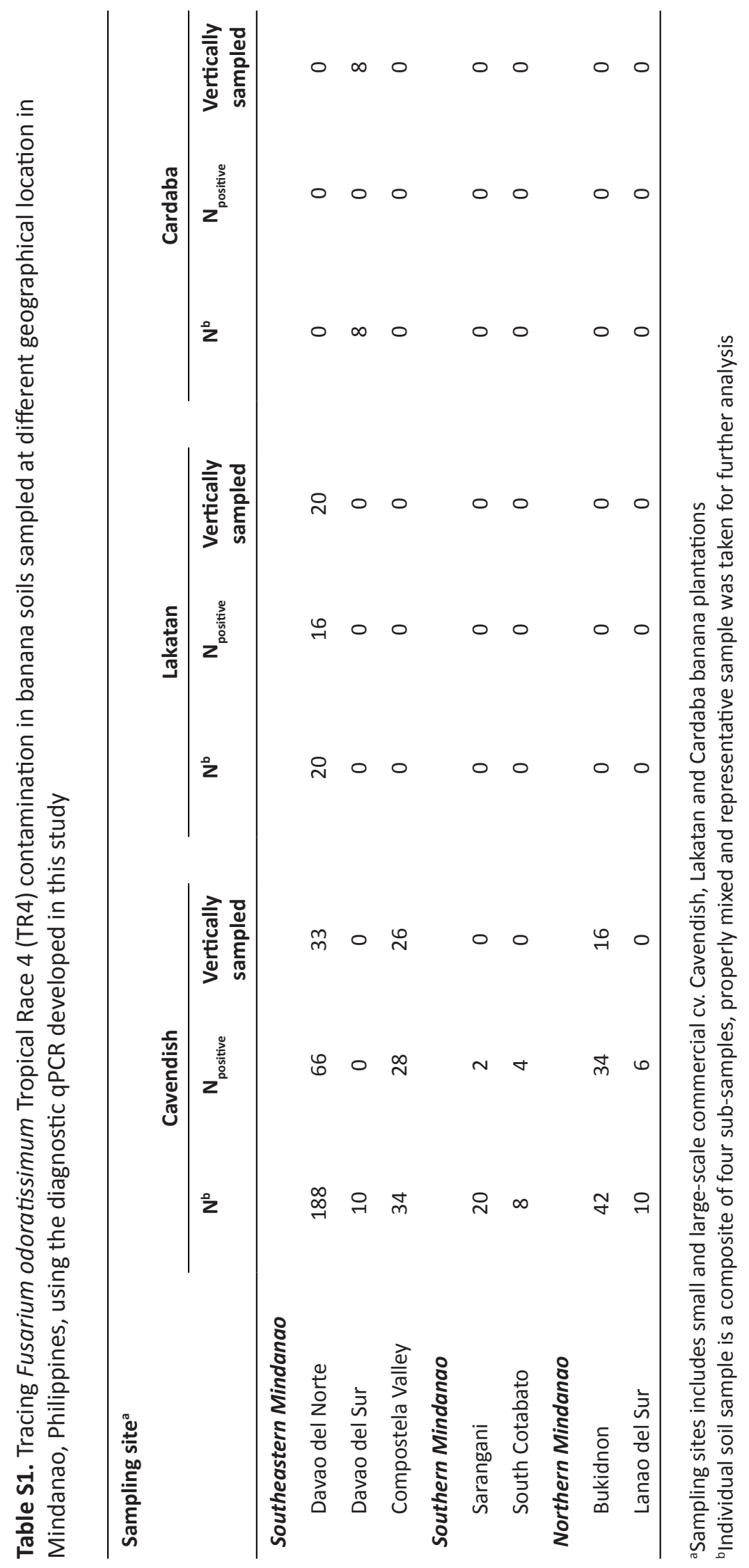


Epidemiology and management of Panama disease

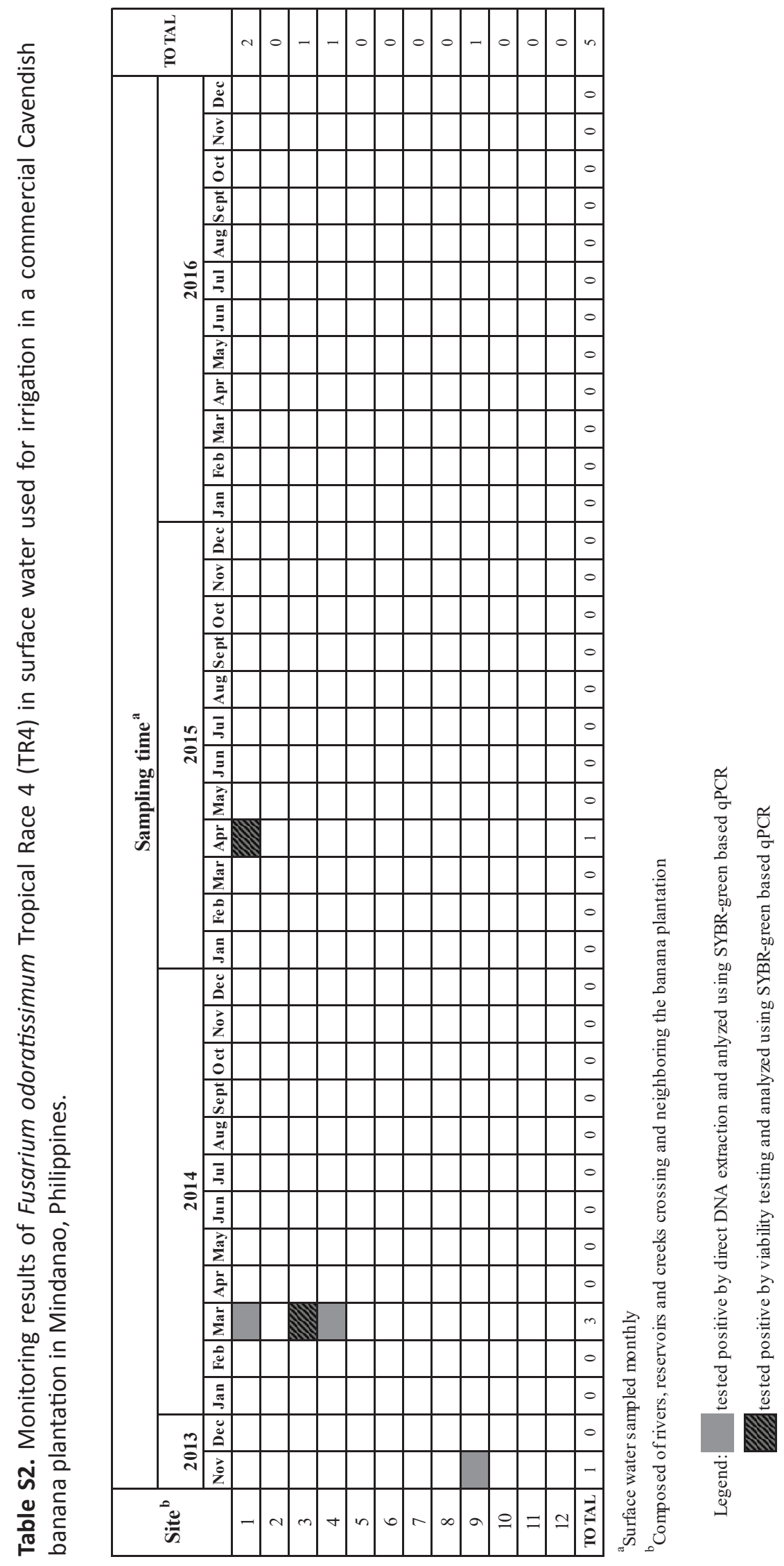




\section{References}

Almeida, R. P.P. (2016) Can Apulia's olive trees be saved? Science (22): 346-348.

Aurore, G., Parfait, B. and Fahrasmane, L. 2009. Bananas, raw materials for making processed food products. Trends in Food Science \& Technology 20: 78-91.

Australia Department of Agriculture and Water Resources. Date accessed 16 April 2019. http://www. agriculture.gov.au/pests-diseases-weeds/plant/panama-disease-tropical-race-4\#secure-anysuspect-specimens

Banihashemi, Z. and deZeeuw, D.J. (1975) The Behavior of Fusarium oxysporum f.sp. melonis in the Presence and Absence of Host Plants. Phytopathology 65:1212-1217.

Bebber, D., Holmes, T. and Gurr, S.J. (2013) The global spread of crop pests and pathogens. Global Ecology and Biogeography 23:1398-1407.

Blomme, G., Ploetz, R., Jones, D., De Langhe, E., Price, N., Gold, C., . . Buddenhagen, I. (2013). A historical overview of the appearance and spread of Musa pests and pathogens on the African continent: highlighting the importance of clean Musa planting materials and quarantine measures. Annals of Applied Biology 162(1), 4-26.

Bourke, P.M. A. (1964) Emergence of Potato Blight. Nature (203):805-808.

Molina, I.W. (2009) Understanding strain diversity in Fusarium oxysporum f.sp. cubense and history of introduction of 'Tropical Race 4' to better manage banana production. In: Jones, D. and Van den Bergh, I. (eds.) Proc.IS on Banana Crop Prot., Sust. Prod. And Impr. Livelihoods, White River, South Africa. ISHS Acta Horticulturae 828,193-204.

Burdon, J.J and Thrall, P.H. (2007) Pathogen evolution across the agro-ecological interface: implications for disease management. Blackwell Publishing 1:57-65.

Bureau of Agricultural Statistics. (2011) Available at http://openstat.psa.gov.ph/search/field_topic/ agriculture-forestry-and-fisheries-1.

Busse, M.D., Hubbert, K.R., Fiddler, G.O., Shestak, C.J. and Powers, R.F. (2005) Lethal soil temperatures during burning of masticated forest residues. International Journal of Wildland Fire 14:267-276.

Butler, D. (2013). Fungus threatens top banana. Nature 504, 195-196.

Chittarath, K., Mostert, D., Crew, K. S., Viljoen, A., Kong, G., Molina, G., \& Thomas, J. E. (2017). First report of Fusarium oxysporum f.sp. cubense tropical race 4 (VCG 01213/16) associated with Cavendish bananas in Laos. Plant Disease 449.

Cooke, B.M., Jones, D. G. and Kaye, B. The Epidemiology of Plant Diseases. $2^{\text {nd }}$ Edition. Springer, The Netherlands.

Di Pietro, A., Madrid, M. P., Caracuel, Z., Delgado-Jarana, J., \& Roncero, M. I. (2003). Fusarium oxysporum: exploring the molecular arsenal of a vascular wilt fungus. Molecular Plant Pathology 4(5), 315-325.

Diener, A. (2012). Visualizing and quantifying Fusarium oxysporum in the plant host. Molecular Plant Microbe Interaction 25(12), 1531-1541.

Dita, M. A., Garming, H., Van den Bergh, E. B., Staver, C., \& Lescot, T. (2013). Banana in Latin America and the Caribbean: current state, challenges and perspectives Acta Hort, 986 (Proc. Int. ISHSProMusa Symp. on bananas and plantains: towards sustainable global production and improved uses), pp365-380. 
Dita, M., Barquero, M., Heck, D., Mizubuti, E.S.G. and Staver, C.P. (2018) Fusarium Wilt of Banana: Current Knowledge on Epidemiology and Research Needs Toward Sustainable Disease Management. Frontiers in Plant Science 9:1468.

Edel-Hermann,V. and Lecomte, C. (2019) Current Status of Fusarium oxysporum Formae Speciales and Races. Phytopathology 109:512-530.

Erwin, D.C., Bartnicki-Garcia, S. and Tsao, P.H. (1983) Pages 60-276 In: Phytophthora: Its Biology, Taxonomy, Ecology, and Pathology. The American Phytopathological Society, St. Paul, MN, USA.

Faggian R. and Strelkov S.E. (2009) Detection and measurement of Plasmodiophora brassicae. Journal of Plant Growth and Regulation 28(3):282-288.

FAOSTAT. Food and Agricultural Organization of the United Nations Statistical Databases, Production Statistics, Crop-Banana, World production. Available at http://faostat.fao.org/

Fisher, M.C., Henk, D.A., Briggs, C.J., Brownstein, J.S., Madoff, L.C., McCraw, S.L. and Gurr, S.J. (2012) Emerging fungal threats to animal, plant and ecosystem health. Nature 484:186-194.

Frandsen, W.H. and Ryan, K.C. (1986) Soil moisture reduces belowground heat flux and soil temperatures under s burning fuel pile. Canadian Journal of Forest Research 16:244-248.

Garcia, F.A., Ordonez, N., Nakasato, G., Papagiannaki, E., Kalle, V., Arango, R., Meijer, HJG., Seidl, M. and Kema, G.H.J. (2019) The Pathogenicity of Genetically Diverse Fusarium species causing Panama Disease in Banana. PhD thesis, Wageningen University and Research, Wageningen, The Netherlands.

García, F., Ordóñez, N., Konkol, J., Al-Qasim, M., Naser, Z., Abdelwali, M., . . Kema, G. H. J. (2014). First report of Fusarium oxysporum f.sp. cubense tropical race 4 associated with Panama disease of banana outside Southeast Asia. Plant Disease 98(5) 694.

Garcia, F., Ordonez, N., Konkol, J., Al-Qasim, M., Nazer, Z., Abdelwali, M., Salem, N., Waalwijk, C., Ploetz, R., and Kema G.H.J. (2014) First report of Fusarium oxysporum f.sp. cubense Tropical race 4 associated with Panama disease in banana outside southeast Asia. Plant disease 98 (5): 694.

Ghuman, B.S. and Lal, R. (1989) Soil temperature effects of biomass burning in windrows after clearing a tropical rainforest. Field Crops Research 22:1-10.

Gibbs, J.N. (1978a) Development of the Dutch elm disease epidemic in southern England, 1971-6. Annals of Applied Biology (88): 219-28.

Gibbs, J.N. (1978b) Intercontinental epidemiology of Dutch elm disease. Annual Review of Phytopathology (16): 287-307.

Guo, L., Han, L., Yang, L., Zeng, H., Fan, D., Zhu, Y., et al. (2014). Genome and transcriptome analysis of the fungal pathogen Fusarium oxysporum f.sp. cubense causing banana vascular wilt disease. PLoS One 9(4), 1-17.

Hennessy, C., Walduck, G., Daly, A. and Podovan, A. (2005) Weed hosts of Fusarium oxysporum f.sp. cubense tropical race 4 in Northern Australia. Australasian Plant Pathology 34:115-117.

Hollaway, G.J., Evans, M.L., Wallwork, H., Dyson, C.B., and McKay, A.C. (2013) Yield Loss in cereals, caused by Fusarium culmorum and F. pseudograminearum, is related to fungal DNA in soil prior to planting, rainfall, and cereal type. Plant Disease 97: 977-982.

Huang, C-H., Tsai, R-T., and Vallad, G.E. (2016) Development of a TaqMan real-time polymerase chain reaction assay for detection and quantification of Fusarium oxysporum f.sp. lycopersici in soil. Journal of Phytopathology 164:455-463.

Huang, S-C. and Ko, W-H. (2004) Cavendish banana cultivars resistant to Fusarium wilt acquired through somaclonal variation in Taiwan. The American Phytopathological Society 88:580-588. 
Hung, T. N., Hung, N. Q., Mostert, D., Viljoen, A., Chao, C. P., \& Molina, G. (2017). First report of Fusarium wilt on Cavendish bananas, caused by Fusarium oxysporum f.sp. cubense tropical race 4 (VCG 01213/16), in Vietnam. Plant Disease 448.

Hungerford, R.D., Harrington, M.G., Frandsen, W.H. Ryan, K.C., and Niehoff, G.J. (1991) Influence of fire on factors that affect site productivity. In 'Proceedings - Management and productivity of western-montane forest soils', AC Harvey (ed). Pp32-50. USDA Forest Service Intermountain Research Station General Technical Report INT-280.

Hwang, S.F., Howard, R.J., Chang, K.F., Park, B., Burnett, P.A. (1994) Etiology and severity of Fusarium root rot of lentil in Alberta. Canadian Journal of Plant Pathology 16:295-303.

Jimenez-Diaz, R.M., Castillo, P., Jimenez-Gasco, M.M., Landa, B.B., Navas-Cortes, J.A. (2015) Fusarium wilt of chickpeas: biology, ecology and management . Crop Protection 73:16-27.

Jones, D.R. (2002) Risk of spread of banana diseases in international trade and germplasm exchange. In: Proceedings XV ACORBAT Meeting 2002. Cartagena de Indias, Colombia. pp 105-113.

Jones, D.R. (2009) Disease and pest constraints to banana production. Acta Horticulturae 828:21-36.

Jones, D.R. and Diekmann, M. (2000) Safe movement of Musa germplasm. In: Diseases of Banana, Abaca and Enset, D.R. Jones (ed.) CABI Publishing, Wallingford, Oxon, UK, pp 409-423.

Jones, P. (1981) The geography of Dutch elm disease in Britain. Transactions of the Institute of British Geographers, New Series 6:342-36.

Kema, G. H. J., \& Weise, S. (2013). Pathogens: Appeal for funds to fight banana blight. Nature 504(7479), 218.

Komada, H. (1975) Development of a selective medium for quantitative isolation of Fusarium oxysporum from natural soil. Plant Protection Research 8:114-124.

Li, B., Du, J., Lan, C., Liu, P., Weng, Q. and Chen, Q. (2013) Development of a loop-mediated isothermal amplification assay for rapid and sensitive detection of Fusarium oxysporum f.sp. cubense race 4. European Journal of Plant Pathology 135:903-911.

Legg, J.P. (1999) Emergence, spread and strategies for controlling the pandemic of cassava mosaic virus disease in east and central Africa. Crop Protection (18): 627-637.

Li, C., Chen, S., Zuo, C., Sun, Q., Ye, Q., Yi, G., \& Huang, B. (2011). The use of GFP-transformed isolates to study infection of banana with Fusarium oxysporum f.sp. cubense race 4. European Journal of Plant Pathology 131(2), 327-340.

Magnaye, L.V. (2001) Status of Panama disease in the Philippines. In: Molina, A.B., Nik Masedk, N.H., and Liew, K.W (eds.) Banana Fusarium wilt management: towards sustainable cultivation. INIBAP, Los Baňos, Laguna. pp. 50-57.

Marin, D. H., Sutton, T. B., \& Barker, K. R. (1998). Dissemination of bananas in Latin America and the Caribbean and its relationship to the occurrence of Radopholus similis. Plant Disease 82(9): 964974.

Marquardt, S. (2001) "Green Havoc": Panama disease, Environmental Change and Labor Process in the Central American Banana Industry. The American historical review 106 (1): 49-80.

Maryani, N., Lombard, L., Poerba, Y.S., Subandiyah, S., Crous, P.W. and Kema, G.H.J. (2019) Phylogeny and genetic diversity of the banana Fusarium wilt pathogen Fusarium oxysporum f.sp. cubense in the Indonesian centre of origin. Studies in Mycology 92:155-194.

Maymon, M. Shpatz, U., Shpatz, U., Harel, , Y.M., Levy, E., Elkind, , G., Teverovsky, E.,..... Israeli, Y. and Freeman, S. (2018) First Report of Fusarium oxysporum f. sp. Cubense Tropical Race 4 Causing Fusarium Wilt of Cavendish Bananas in Israel. Plant Disease 102 (12): 2655. 
Molina, A.B., Fabregar, E., Sinohin, V.G., Yi, G., and Viljoen, A. (2009) Recent occurrence of Fusarium oxysporum f.sp. cubense tropical Race 4 in Asia. Acta Horticulturae 828:109-115.

Moody, K., Munroe, C.E., Lubigan, R.T., Paller, E.C. Jr., Barcial, P.M., Fabro, L.E., Janiya, J.D. and Magsino, G.L. (2014) Major Weeds of the Philippines. $2^{\text {nd }}$ edition Weed Science Society of the Philippines, Inc. Crop Protection Cluster, University of the Philippines Los Banos, College, Laguna 4031 Philippines.

Moore, N. Y., Bentley, S., Pegg, K. G. and Jones, D. R. (1995) Fusarium Wilt of Bananas. Musa Disease Fact Sheet No. 5 INIBAP.

Mostert, D., Molina, A.B., Daniells, J., Fourie, G., Hermanto, C., Chao, C., Fabregar, E., Sinohin, V.G., Masdek, N., Thangavelu, R., Li, C., Yi, G., Mostert, L., and Viljoen, A. (2017) The distribution and host range of the banana Fusarium wilt fungus, Fusarium oxysporum f.sp. cubense, in Asia. PLoS One 12(7).

Navas-Cortes, J.A., Landa, B.B., Mendez-Rodriguez, M.A., and Jimenez-Diaz, R.M. (2007) Quantitative modeling of the effects of temperature and inoculum density of Fusarium oxysporum f.sp. ciceris races 0 and 5 on development of Fusarium wilt in chickpea cultivars. Phytopathology 97:564-573.

Neary, D.G., Klopatek, C.C., DeBano, L.F., Ffolliott, P.F. (1999) Fire effects on below ground sustainability: a review and synthesis. Forest Ecology and Management 122:51-71.

O'Neill, W. T., Henderson, J., Pattemore, J. A., O'Dwyer, C., Perry, S., Beasley, D. R., et al. (2016). Detection of Fusarium oxysporum f. sp. cubense tropical race 4 strain in northern Queensland. Australasian Plant Disease Notes11:33.

Ordoñez N., Seidl M.F., Waalwijk C., Drenth A., Kilian A., Thomma B.P.H.J., et al. (2015) Worse Comes to Worst: Bananas and Panama Disease-When Plant and Pathogen Clones Meet. PLoS Pathogen 11(11).

Ordóñez, N., García-Bastidas, F., Laghari, H. B., Akkary, M. Y., Harfouche, E. N., al Awar, B. N., \& Kema, G. H. J. (2016). First report of Fusarium oxysporum f.sp. cubense tropical race 4 causing Panama disease in Cavendish bananas in Pakistan and Lebanon. Plant Disease 100(1):209.

Pegg. K.G., Moore, N.Y., and Bentley, S. (1996) Fusarium wilt of banana in Australia: a review. Australian Journal of Agricultural Research 47:637-650.

Pittaway, P.A., Nasir, N. and Pegg, K.G. (1999) Soil receptivity and host-pathogen dynamics in soils naturally infested with Fusarium oxysporum f.sp. cubense, the cause of Panama disease in bananas. Australian Journal of Agricultural Research 50:623-628.

Ploetz, R. C. (2015b) Management of Fusarium wilt of banana: A review with special reference to tropical race 4. Crop Protection 73:7-15.

Ploetz, R., Freeman, S., Konkol, J., Al-bed, A., Naser, Z., Shalan, K., Barakat, R., and Israeli, Y. (2015c) Tropical race 4 of Panama disease in the Middle East. Phytoparasitica 43:283-293.

Ploetz, R.C. (1990) Variability in Fusarium oxysporum f.sp. cubense. Canadian Journal of Botany 68:1357-1363.

Ploetz, R.C. (2000) Panama disease: a classic and destructive disease of banana. In: Plant Health Progress.

Ploetz, R.C. (2005) Panama disease, an old enemy rears its ugly head. Parts 1 and 2. In: Plant Health Progress.

Ploetz, R.C. (2006) Fusarium wilt of banana is caused by several pathogens referred to as Fusarium oxysporum f.sp. cubense. The American Phytopathological Society 96:653-656.

Ploetz, R.C. (2015b) Fusarium wilt of banana. Phytopathology 105:1512-1521. 
Ploetz, R.C. and Pegg, K.G. (1999) Fusarium wilt. In: D.R.Jones (ed.). Diseases of banana. CAB International, Wallingford, Oxon, UK. pp143-159.

Ploetz, R.C., Thomas, J.E. and Slabaugh, W.R. (2003) Diseases of banana and plantains. In: Ploetz, R.C (ed.) CAB International. Diseases of Tropical Fruit Crops.

Podovan, A., Henessey, C. and Walduck, G. (2003) Alternative hosts of Fusarium oxysporum f.sp. cubense tropical race 4 in Northern Australia. In: $2^{\text {nd }}$ International Symposium on Fusarium wilt on banana. PROMUSA-INIBAP/EMBRAPA. Salvador de Bahia, Brazil, 22-26 Sept.

Preisler, H.K., Haase, S.M. and Sackett, S.S. (2000) Modelling and risk assessment for soil temperatures beneath prescribed forest fires. Environmental and Ecological Statistics 7:239-254.

ProMusa (2018) Accessed at http://www.promusa.org/blogpost556-NPPO-declares-TR4-eradicatedfrom-Israel.

Roperos, N.I and Magnaye, L.V. (1991) Status of banana disease in the Philippines. In: Valmayor, R.V., Umali, B.E. and Bejosano, C.P. (eds.). Banana diseases in Asia and the Pacific. Proceedings of a technical meeting on banana diseases affecting banana and plantain in Asia and the Pacific. INIBAP, Montpellier. Brisbane, Australia, 15-18 April 1991. 180p.

Soluri, J. (2002). Accounting for taste: Export bananas, mass markets, and Panama disease. Environmental History 7( 3), 386- 410.

Stover, R.H. (1962) Fusarial wilt (Panama disease) of bananas and other Musa species. Kew, UK: Commonwealth Mycological Institute.

Stover, R.H. and Simmonds, N.W. (1987) Bananas $3^{\text {rd }}$ edition. Longmans Scientific and Technical, London, UK.

Stuart, S. N., Chanson, J. S., Cox, N.A., Young, B.E., Rodrigues, A.S.L., Fischman, D. L. and Waller, R.W. (2004) Status and Trends of Amphibian Declines and Extinctions Worldwide. Science 306 (5702) 1783-1786.

Su, H.J., Hwang,S.C., Ko, W.H. (1986) Fusarial wilt of Cavendish bananas in Taiwan. Plant Disease 70:814-818.

Thangavelu, R., Mostert, D., Gopi, M., Ganga Devi, P., Padmanaban, B., Molina, A.B. and Viljoen, A. (2019) First detection of Fusarium oxysporum f. sp. cubense tropical race 4 (TR4) on Cavendish banana in India. European Journal of Plant Pathology.

Thresh, J. M. and Cooter, R.J. (2005) Strategies for controlling cassava mosaic virus disease in Africa. Plant Pathology 54:587-614.

Thornton, P., \& Cramer, L. (2012). Impacts of climate change on the agricultural and aquatic systems and natural resources within the CGIAR's mandate. Paper presented at the CCAFS Working Paper 23. CGIAR Research Program on Climate Change, Agriculture and Food Security (CCAFS), Copenhagen, Denmark.

Perez-Vicente, L. (2004) Fusarium wilt (Panama Disease) of bananas: an updating review of the current knowledge on the disease and its causal agent. In. Memorias de XV Reunion Internacional de ACORBAT (Oaxaca, MX). pp 1-14.

Waalwijk, C., van der Heide, R., de Vries, I., van der Lee, T., Schoen, C., Costrel-de Corainville, G., HauserHahn, I., Kastelein, P., Kohl, J., Lonnet, P., Demarquet, T., and Kema, GHJ. (2004) Quantitative detection of Fusarium species in wheat using TaqMan. European Journal of Plant Pathology 110:481-494.

Waite, B.H. and Dunlap, V.C. (1953) Preliminary host range studies with Fusarium oxysporum f.sp. cubense. Plant Disease 37:79-80. 
Waman, A.A., Bohra, P., Sathyanarayana, B.N., Chandrashekar, S.C. and Rani, R.T. (2013) Are bananas (Musa spp.) really safe from their aesthetic relatives? Screening potential alternative hosts of Fusarium oxysporum f.sp. cubense. Journal of Horticultural Science and Biotechnology 88 (5):559562.

Yadeta, K. A., \& Thomma, B. P. (2013). The xylem as battleground for plant hosts and vascular wilt pathogens. Frontiers in Plant Science 4, 1-12.

Yoshida, K., Schuenemann, V.J., et al. (2013) The rise and fall of the Phytophthora infestans lineage that triggered the Irish potato famine. Genomics and Evolutionary Biology.

Zheng, SJ., Garcia-Bastidas, F., Li, X., Zeng, L., Bai, T., Xu, S., Li, H., Fu, G., Yu, Y., Yang, L., Nguyen, HC., Dounneuang, D., Khaing, A., Drenth, A., Seidl, M., Meijer, H.J.G., and Kema, G.H.J. (2018) New Geographical Insights of the Latest Expansion of Fusarium oxysporum f.sp. cubense Tropical Race 4 Into the Greater Mekong Subregion. Frontiers in Plant Science.

Zhou, Q., Chen, Y., Yang, Y., Ahmed, H.U., Hwang, S-F., Strelkov, S.E. (2014) Effect of inoculum density and quantitative PCR-based detection of Rhizoctonia solani AG-2-1 and Fusarium avenaceum on canola. Crop Protection 59:71-77. 

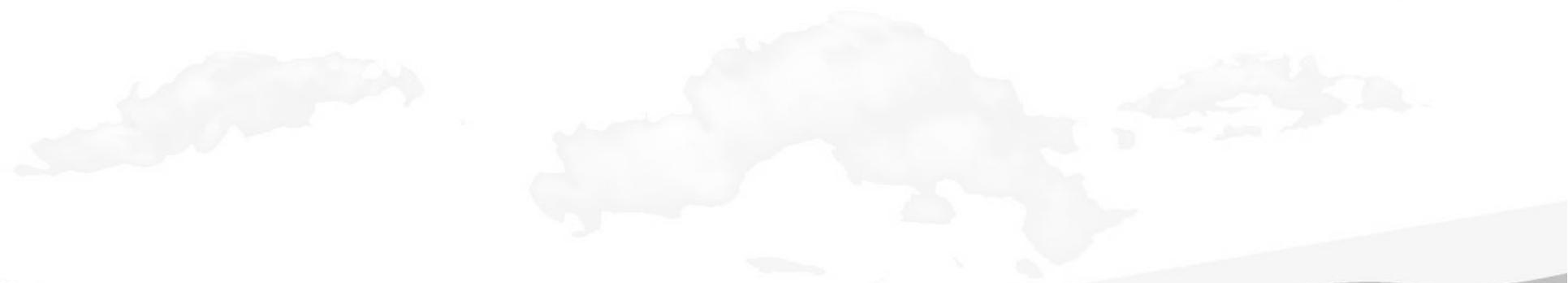

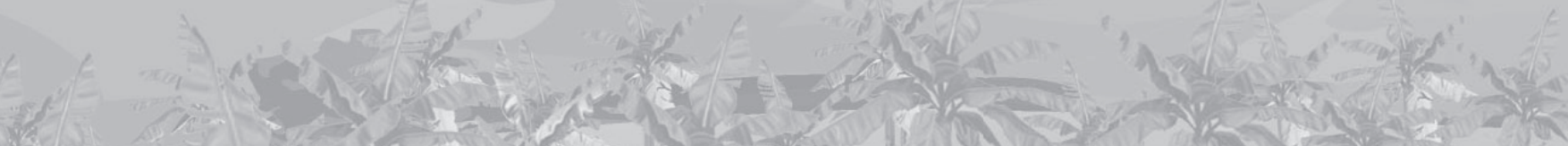

1.

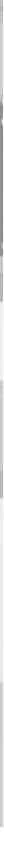




\section{CHAPTER 4}

\section{Efficacy of disinfectants against the causal agent of Panama disease in Cavendish bananas}

Salacinas, Maricar ${ }^{1}$, Mamora, Samuel Herbert ${ }^{2}$, Corcolon, Benny ${ }^{3}$, Mirzadi Gohari, Amir ${ }^{4}$, Ghimire, Bikal ${ }^{1}$, Meijer, Harold J. G. ${ }^{1}$ and Kema, Gerrit H.J. ${ }^{1 *}$ 


\section{Abstract}

Panama disease is one of the most damaging diseases of banana that currently puts the global production and food security at risk. The causal agent, Fusarium odoratissimum, colloquially called tropical race 4 (TR4), is pathogenic on the Cavendish varieties and many locally important cultivars and easily and rapidly spreads within and between farms. Despite the fact that limited information exists on the efficacy of disinfectants particularly on the persistent chlamydospores, they have been used as a front-line defense against the spread of TR4 in the banana production areas. Here, 13 disinfectants, majority marketed in the Philippines, were tested for efficacy on TR4 mycelium, conidiospores, chlamydospores suspensions and chlamydospore-infested soil. They encompass five chemical groups; quaternary ammonium, halogen, alcohol, diamidine and aldehyde, and were tested at different concentrations and exposure times. Ten disinfectants controlled mycelial growth at the manufacturer's rate with the exception on one quaternary ammonium-based disinfectant. Conidiospores in suspension are sensitive to all tested disinfectants at the manufacturer's rate with minimum exposure time of 15 seconds, reducing the concentration also showed efficacy except for formalin and ethyl alcohol. Eleven disinfectants showed adequate efficacy in all tested concentrations towards filtered chlamydospores in aqueous suspensions with the exception of calcium hypochlorite-based disinfectant and ethanol at lower rates. Despite in vitro efficacy, all disinfectants were largely ineffective once chlamydospores were in soil, the natural substrate of these propagules, except the diamidine-based disinfectants that showed full efficacy at the recommended rates. Increasing the concentration of the disinfectants increased their efficacy for TR4 mycelium and propagules independently from the used substrate, except for ethanol. Moreover, the minimal exposure of the disinfectants for in vitro or in situ tests significantly deviates, which greatly affects their efficacy. Furthermore, Formo and Vanodine are highly corrosive to metal. Our results illustrate that the overall efficacy of disinfectants largely depends on the substrate carrying TR4 propagules and exposure time. Suboptimal adequate quarantine measures, therefore, contribute to continued local, regional and international TR4 dissemination.

Keywords: efficacy, disinfectant, TR4, quarantine bath, propagule type, corrosiveness 


\section{Introduction}

The United Nations sustainable development goals indicate that crop production has to increase to meet future demands for food and feed. With a continuously increasing global population, plant production has to increase and yield and post-harvest losses have to be reduced. Evidently, plant disease in staple crops are a great concern and reduced efficacies of disease control agents contribute to increasing yield gaps (Fisher et al., 2018; Bebber et al., 2013). Bananas rank among the top-10 most important food crops with estimated annual consumption of 100 billion as staple food or fruit (Aurore et al., 2009; Churchill, 2011). They include dessert and cooking types and are extensively grown in the (sub) tropics either in backyards, mixed-crops, small-scale farming or industrial monocrops. Overall, $85 \%$ of the total production is for local consumption as staple crop and $15 \%$ enters international markets (FruitTrop, 2017). The latter represents an annual production of more than 148 million tonnes (FAOSTAT, 2016), and is dominated by Cavendish varieties (-90\%) that serve as an important cash crop for agriculture-based economies with an estimated value of US\$ 35.2 billion (Churchill, 2011).

The genus Fusarium contains a wide range of soil-borne pathogens, of which several formae speciales cause wilting disease in a range of crops (Chakrabarti, 2013). Until recently $F$. oxysporum f.sp. cubense (Foc) was the agreed pathogen causing Fusarium wilt or Panama disease in banana. However, a recent taxonomical revision showed that the polyphyletic origin of Foc should be taken as a lead and hence, resulted in a new nomenclature (Maryani et al., 2019). The conclusion is that Panama disease is caused by a suite of Fusarium spp., including the new species $F$. odoratissimum that is colloquially called tropical race 4 (TR4), which devastates Cavendish bananas as well as many local varieties (Garcia, 2019). Panama disease is one of the most devastating plant diseases, exemplified by the epidemic in Gros Michel banana plantations in Panama in the mid-1950s. This paved the way to the conversion of the Gros Michel based export trade to the contemporary Cavendish based industry (Stover, 1962; Perez-Vicente, 2004). The appearance of TR4 on Cavendish bananas causes havoc in the industry, as it disseminated across Southeast Asia and hence forward to the Indian subcontinent, the Middle East and Africa (Chittarath et al., 2017; GarcíaBastidas et al., 2015; Hung et al., 2017; Mostert et al., 2017; Ordóñez et al., 2016; Zheng et al., 2018). and recently in United Kingdom and Colombia (https://www.sciencemag.org/ news/2019/07/devastating-banana-disease-may-have-reached-latin-america-could-driveglobal-prices). This can be associated with its wide host range including sweet dessert and cooking bananas. The socio-economic impact of this devastating strain rapidly increases due to its international and continental manifestation in Cavendish bananas as well as many local varieties (Ploetz, 2015a). Despite its global dissemination there are currently no effective and long-term control measures available to manage Panama disease in banana. Moreover, contrary to the previous epidemic in "Gros Michel", there is presently no resistant, widely accepted replacement for Cavendish bananas. Hence, investigating methods to prevent TR4 incursions and effective disease management strategies once it occurs are crucial for the global industry and millions of smallholders. 
This asexual fungal pathogen produces three types of spores: chlamydospores, macroconidia and microconidia. Conidia are produced in large quantities in the xylem vessels and facilitate rapid infestation in the entire host plant. Chlamydospores on the other hand, are thick-walled and are formed on senescing hyphae or germ tubes or inside the conidia under abiotic stress conditions (Beckman, 1969; 1989; 1990; Schippers, 1981; Vandermolen et al., 1977). They easily persist for 30 to 50 years in the soil in the absence of the susceptible host (Ploetz, 2015a). The primary risk factor for introduction of TR4 into new areas is the movement of infested soils or infected planting material. The latter can be rhizomes or suckers (with attached soil) contaminated with mycelium, conidiospores and/or chlamydospores. Hence, regional, international and intercontinental traffic is considered to be the major risk factor for TR4 dissemination (García-Bastidas et al., 2015; Zheng et al., 2018). Therefore, strengthening biosecurity policies and implementing disease management strategies are top priorities aimed to control and limit the spread of inoculum in and across the production areas. In the Philippines the disease continues to spread after its incursion in early 2000 (Molina et al., 2009), despite the implementation of biosecurity measures employing disinfectants to decontaminate tools, footwear, vehicle and equipment. Therefore, application of disinfectants requires thorough efficacy testing simulating actual processes of routine disinfection as it may attenuate good agricultural practices to merely and costly window dressing.

Disinfectants are organic or chemical agents used to decontaminate skins, footwear or farm equipment (Cheah et.al., 2009). The efficacy of disinfectants largely depends on their concentration (dilution effect), contact time, active ingredients, formulation, the presence of organic matter (acting as physical barrier for surface contact) and the tissue of the target organism (Russel, 2002; Best et al., 1990; Gehr et al., 2003, Rutala, 2008). Several in vitro studies have been conducted to verify the most effective disinfectant on different propagules of the causal Fusarium spp.. Nel et al. (2007) showed that quaternary ammonium-based disinfectants such as Sporekill and Prazin can easily (30 sec exposure time) inhibit conidial growth of subtropical race 4 (ST4). Meldrum et al. (2013) confirmed the efficacy of Sporekill against TR4 conidia after at least 30 sec exposure time. However, the efficacy of disinfectants is greatly influenced by their access to propagules of Fusarium spp. in their natural habitat, such as e.g. soil. Therefore, it is of great importance to test efficacies on purified (chlamydo) spores as well as in soil to simulate in-field scenarios. Recently, Nguyen et al. (2019) showed that chlamydospore/soil suspensions of a race 1 Fusarium isolate and TR4 did not reduce the efficacy of quaternary ammonium-based compounds (active ingredient $\geq 10 \%$ ) after a 30 sec exposure time.

Here, we tested the efficacy of all disinfectants that are commercially available in the Philippines against TR4 under in vitro (mycelium, conidia and chlamydospores) and in situ (in soil) conditions at various concentrations and exposure times. As the deployment of disinfectants in the field also depends on their corrosiveness (Bennett et al., 2011; James et al., 2012; Meldrum et al., 2013), we also tested their capacity to oxidize aluminum (Al) and iron (Fe). Finally, we monitored entrance gates at a commercial farm to determine the actual 
exposure time to disinfectants while passing through obligatory foot baths and tire baths. These data enable an analysis of necessary versus actual quarantine measures to minimize on-farm, regional and international dissemination of TR4.

\section{Materials and methods}

\section{TR4 isolate and propagule preparation}

Isolate Phil 2.6c from Davao del Norte, Mindanao, the Philippines, was previously diagnosed as TR4 by whole genome sequencing (Ordonez et al., 2015), and was therefore used throughout this study. A monospore of this isolate was grown on Komada medium (Komada, $1975)$ at $25^{\circ} \mathrm{C}$ in the dark for five days and mycelial plugs $(0.5 \mathrm{~cm}$ diameter) from the margin of the culture as well as conidiospores $\left(2 \times 10^{5}\right.$ spores $\left.\mathrm{ml}^{-1}\right)$, produced as described by Garcia et al. (submitted), were used for in vitro efficacy tests. Chlamydospores were prepared following the protocol described by Amorim et al. (2009) with modifications. Mycelial plugs were aseptically added to a twice autoclaved $\left(121^{\circ} \mathrm{C}\right.$ for 60 minutes) substrate composed of washed-filtered sandy soil, corn powder and distilled water in a $500 \mathrm{ml}$ Erlenmeyer flask. The flask was incubated at $25^{\circ} \mathrm{C}$ with 12 hour photoperiod for 15 days and the content was daily homogenized by shaking. Subsequently, $200 \mathrm{~g}$ of autoclaved sandy soil were added, thoroughly mixed and flasks were then incubated for another six weeks under the same conditions. After incubation, soil with chlamydospores was dried for three days at $30^{\circ} \mathrm{C}$, the presence of chlamydospores was determined by microscopic observation and their concentration (colony forming units per gram soil, $\mathrm{cfu}, \mathrm{gr} \mathrm{soil}^{-1}$ ) was determined by a plate dilution technique (Gilchrist et al., 1973).

\section{Disinfectants}

Thirteen disinfectants, distributed over five chemical groups, were used in this study (Table 1) and comprise the major commercially available disinfectants in the Philippine market. All were provided as liquid formulations, except Hichlon 70 that was provided as a powder. Before each experiment, fresh dilutions were prepared with sterile distilled water.

\section{Experimental design}

Inoculum source (mycelia, conidiospores or chlamydospores in suspension and soil), concentration and exposure time were varied in this study. Disinfectant concentrations depended on the inoculum sources. Incubations in sterile distilled water or on unamended potato dextrose agar (PDA; Himedia, India) served as controls, each treatment was replicated five times and each experiment was conducted twice. 
Table 1. Disinfectants evaluated in vitro against Fusarium odoratissimum Tropical Race 4 (TR4).

\begin{tabular}{|c|c|c|c|c|c|}
\hline $\begin{array}{l}\text { Chemical } \\
\text { group }\end{array}$ & $\begin{array}{l}\text { Local trade } \\
\text { name }\end{array}$ & Active ingredient & Strength & $\begin{array}{l}\text { Recommended } \\
\text { concentration }^{\mathrm{a}}\end{array}$ & Manufacturer \\
\hline \multirow[t]{8}{*}{$\begin{array}{l}\text { Quaternary } \\
\text { ammonium }\end{array}$} & Biocit & $\begin{array}{l}\text { Benzalkonium } \\
\text { chloride }\end{array}$ & $40 \%$ & $3 \%$ & $\begin{array}{l}\text { FKA Agri-Chemical } \\
\text { Corporation } \\
\text { (Philippines) }\end{array}$ \\
\hline & Germ-X & $\begin{array}{l}\text { Benzalkonium } \\
\text { chloride }\end{array}$ & $50 \%$ & $3 \%$ & $\begin{array}{l}\text { Shanghai Bosman } \\
\text { Industries Co. Ltd. } \\
\text { (China) }\end{array}$ \\
\hline & GUAA & $\begin{array}{l}\mathrm{N} \text {-alkyl(C12-C16) } \\
\text { (benzyl) dimethylam- } \\
\text { onium chloride }\end{array}$ & $\begin{array}{l}0.50 \mathrm{~g} / \\
100 \mathrm{~g}\end{array}$ & $1 \%$ & $\begin{array}{l}\text { GUAPEX (Czech } \\
\text { Republic) }\end{array}$ \\
\hline & Ivagard $^{b}$ & $\begin{array}{l}\text { Di-C8-10-alkyldi- } \\
\text { methylchlroides + } \\
\text { alkyl dimethyl benzyl } \\
\text { ammonium chloride }\end{array}$ & $48+32 \%$ & $1 \%$ & $\begin{array}{l}\text { Lonza Ltd. } \\
\text { (Switzerland) }\end{array}$ \\
\hline & Agresource & $\begin{array}{l}\text { Benzalkonium } \\
\text { chloride }\end{array}$ & $40 \%$ & $3 \%$ & $\begin{array}{l}\text { Agresource Inc. } \\
\text { (Philippines) }\end{array}$ \\
\hline & Microvenum & $\begin{array}{l}\text { Didecyl Dimethyl } \\
\text { ammonium chloride }\end{array}$ & $80 \%$ & $2 \%$ & $\begin{array}{l}\text { Connect Chemicals } \\
\text { GmbH (Germany) }\end{array}$ \\
\hline & Gentrol & $\begin{array}{l}\text { Benzalkonium } \\
\text { chloride }\end{array}$ & $40 \%$ & $3 \%$ & $\begin{array}{l}\text { TLV Agro-Sales } \\
\text { Corporation } \\
\text { (Philippines) }\end{array}$ \\
\hline & Multisept & $\begin{array}{l}\text { Quaternary ammonia } \\
\text { (2) + aldehyde + } \\
\text { alcohol }\end{array}$ & - & $1 \%$ & $\begin{array}{l}\text { Polara Chemical } \\
\text { Corporation } \\
\text { (Philippines) }\end{array}$ \\
\hline \multirow[t]{2}{*}{ Halogens } & Hichlon 70 & Calcium hypochlorite & $70 \%$ & $6 \mathrm{ppm}$ & $\begin{array}{l}\text { Nippon Soda Co. } \\
\text { Ltd.(Japan) }\end{array}$ \\
\hline & Vanodine & $\begin{array}{l}\text { Phosphoric acid } \\
\text { + sulphuric acid + } \\
\text { iodine + alcohol }\end{array}$ & $\begin{array}{l}20 / 10 / \\
5 / 20 \%\end{array}$ & $1 \%$ & $\begin{array}{l}\text { Evans Vanodine } \\
\text { International } \\
\text { (England) }\end{array}$ \\
\hline Alcohols & Ethanol & Ethyl alcohol & $99 \%$ & none & $\begin{array}{l}\text { Scharlab S.L. } \\
\text { (Spain) }\end{array}$ \\
\hline Diamidines & Formo & $\begin{array}{l}\text { 2,2-Dibromo-3- } \\
\text { nitrilopropionamide }\end{array}$ & $20 \%$ & $1 \%$ & $\begin{array}{l}\text { Texicon } \\
\text { Agriventures } \\
\text { Corporation } \\
\text { (Philippines) }\end{array}$ \\
\hline Aldehyde & Formalin & Formaldehyde & $37 \%$ & none & - \\
\hline
\end{tabular}


For efficacy tests on TR4 mycelia, disinfectants were directly added to autoclaved PDA after cooling to $\sim 50^{\circ} \mathrm{C}$, at $0.5,1,2$ and 4 times the recommended rate. The disinfectant-amended media were aseptically dispensed into $90-\mathrm{mm}$-diameter plastic petri dishes and allowed to solidify. Plugs of freshly grown mycelia of TR4 were placed at the center of the plates and were incubated for five days at room temperature $\left( \pm 27^{\circ} \mathrm{C}\right)$.

The efficacy on TR4 conidiospores was tested by adding $500 \mu l$ spore suspension to disinfectant solutions (at concentration of $0.25,0.5,1$ and 2 times recommended rate) in 1:1 ratio and incubation exposure times of $15,30,60,120$ and $300 \mathrm{sec}$. We could not apply shorter exposure times as the minimal handling time of samples/experiments was $15 \mathrm{sec}$. After incubation, spore suspensions were immediately diluted $20 x$ with buffer solution ( $1 / 4$ strength Ringer, Honeywell Fluka, Germany) and thoroughly mixed to stop the exposure to the disinfectant. Subsequently, a $100 \mu$ l sample was plated on PDA and subsequently incubated at $25^{\circ} \mathrm{C}$ in an incubator (Elbanton, Hettich Benelux B.V. The Netherlands) for three days and efficacy was determined as the number of developed TR4 colonies per PDA plate.

For chlamydospores suspension testing, $0.5 \mathrm{~g}$ of soil $\left(10^{6}\right.$ chlamydospores. $\left.\mathrm{gr}^{-1}\right)$ was diluted with $20 \mathrm{ml} 1 / 4$ strength Ringer's solution to release chlamydospores from the soil by vortexing for $10 \mathrm{~min}$. Subsequently, $500 \mu \mathrm{l}$ of the resultant suspension was mixed in a 1:1 ratio with disinfectant solutions (at concentration of $0.25,0.5,1$ and 2 times recommended rate) for 15 , $30,60,120$, and $300 \mathrm{sec}$, respectively. To stop the treatment, samples of $50 \mu \mathrm{l}$ were diluted $20 \mathrm{x}$ in $1 / 4$ Ringer's solution and $100 \mu \mathrm{l}$ was plated directly on Komada medium amended with $100 \mathrm{mg} . \mathrm{L}^{-1}$ streptomycin, which were then incubated at room temperature $\left( \pm 27^{\circ} \mathrm{C}\right)$ for three days. Efficacy data were collected by the number of growing TR4 colonies on each plate.

The efficacy of disinfectants on chlamydospores embedded in soil was tested by mixing $0.5 \mathrm{~g}$ of infested soil $\left(10^{6}\right.$ chlamydospores. $\left.\mathrm{gr}^{-1}\right)$ and $5 \mathrm{ml}$ disinfectant solution at three concentrations (1, 2 and 4 times recommended rate). After $15 \mathrm{sec}, 45 \mathrm{ml}$ of $1 / 4$ Ringer's solution was added to stop the treatment and the mixture was directly filtered (Durapore membrane filter 0.45 $\mu \mathrm{m}$ pore size, Millipore, Ireland) by vacuum infiltration (Sartorius, Germany). The filter with treated chlamydospores was then transferred into $20 \mathrm{ml} 1 / 4$ strength Ringer's solution in a $50 \mathrm{ml}$ plastic tube that was then vortexed (MoBio Genie 2, USA) for $30 \mathrm{~min}$. The resultant chlamydospore suspension $(100 \mu \mathrm{l})$ was subsequently plated on Komada medium amended with $100 \mathrm{mg} . \mathrm{L}^{-1}$ streptomycin and incubated at $\pm 27^{\circ} \mathrm{C}$ for three days.

\section{Assessment of disinfectants corrosiveness}

All disinfectants were assessed for their corrosiveness to aluminum (Al) and iron (Fe) at the Tadeco Inc. chemistry laboratory (Davao del Norte, Philippines). Al and Fe samples were separately exposed to $375 \mathrm{ml}$ disinfectant samples (1\% per liter), two replicates per treatment and monitored for 3, 6, 9 and 24 hours. At each time point $50 \mathrm{ml}$ were pipetted for $\mathrm{Al}$ and Fe content analysis using inductively coupled plasma optical emission spectrophotometry (Perkin Elmer, USA). 


\section{Measuring real-time exposure with disinfectants in the field}

In order to monitor the potential efficacy of disinfectants under practical conditions, a big commercial Cavendish plantation in Davao del Norte, Philippines (6,613 ha planted) was visited and we recorded the duration of exposure in foot baths and vehicles tire bath stations (first contact to last contact in sec) at three major entry and exit points of the farm $(n=400)$.

\section{Determining cost of quarantine baths}

In the same commercial banana plantation mentioned above, the costs of installing and maintaining quarantine baths were calculated. There were 18 foot baths and tire bath stations installed in the major entry/exit points for the entire plantation and the estimated cost was presented (US dollar).

\section{Data and statistical analysis}

For tests against TR4 mycelia, colony diameter (two cross-sectional measurements per colony per plate) was measured and radial growth was presented in millimeter. The effectiveness of disinfectants in inhibiting colony formation of TR4 spores was evaluated in terms of cfu. $\mathrm{ml}^{-1}$ suspension or cfu. ${ }^{-1}$ soil. It is assumed that cfu's resulted from individual chlamydospores capable of initiating colony development. The means were subjected to statistical analysis using the Mann-Whitney test (statistical tool version).

\section{Results}

\section{Disinfectants inhibit mycelial growth}

For the efficacy tests on mycelial growth, ethanol and Hichlon70 were excluded. The former hampers media solidification at high concentrations and the latter was only available as a powder formulation. All quaternary ammonium-based disinfectants completely inhibited mycelial growth at $1 x$ (recommended) and $0.5 x$ rates, except for the GUAA and Multisept, which showed reduced inhibition at $1 x / 0.5 x$ and $0.5 x$, respectively. However, GUAA was effective at $2 x$ the recommended rate. All other compounds inhibited mycelial growth at all tested rates (Figure 1).

\section{Conidiospores are sensitive to disinfectants even at low concentrations}

We used the cfu's on water controls to confirm that conidiospores $\left(2 \times 10^{5} \cdot \mathrm{ml}^{-1}\right.$ conidia) were viable. All disinfectants showed excellent efficacy at all rates and exposure times except for formalin and ethanol that allowed colony formation at $5 / 7.5 \%$ and $35 / 40 \%$ concentrations, respectively (Figure 2 ). The other disinfectants were additionally tested at $0.0625 \mathrm{x}$ and $0.125 x$ rates and still showed full efficacy at all exposure times (data not shown). 

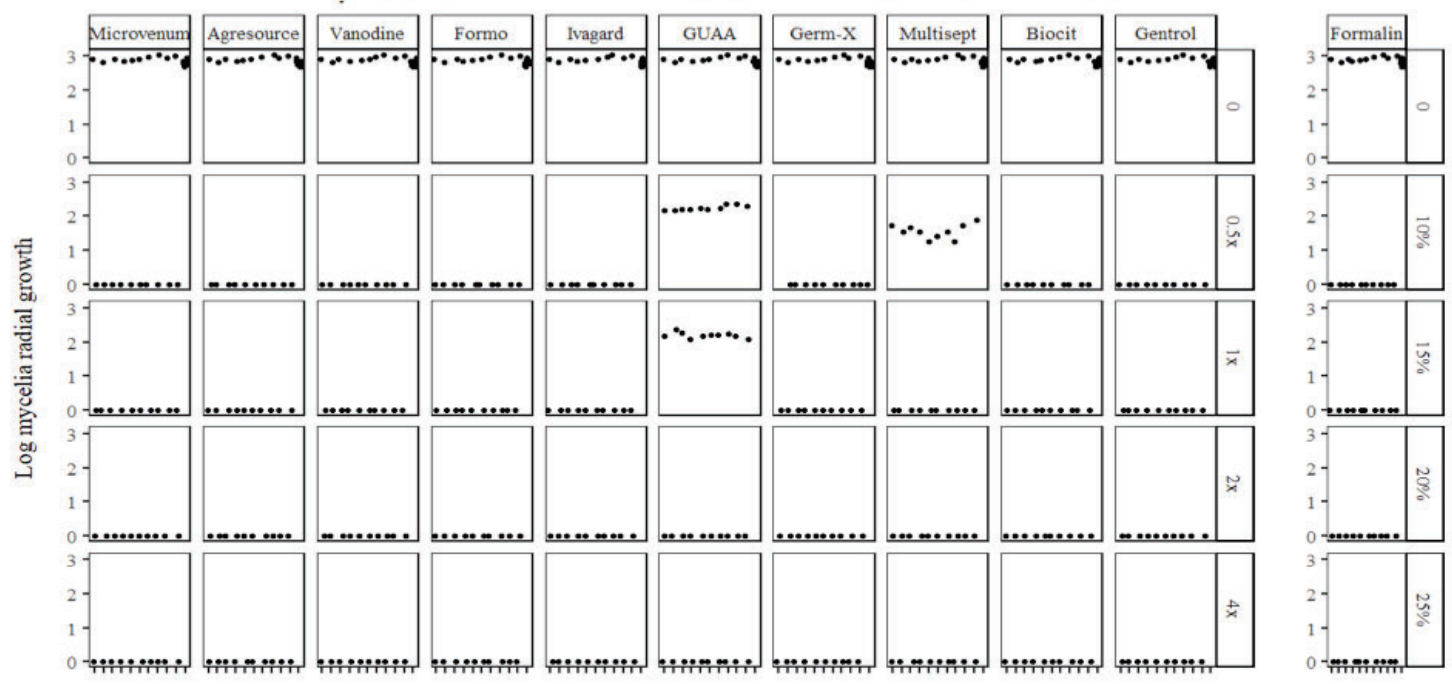

Figure 1. Efficacy of 11 disinfectants on Fusarium odoratissimum Tropical Race 4 (TR4), expressed as log transformed mycelia radial growth in $\mathrm{mm}$ on amended Komada medium in petri dishes at 0, 0.5, 1,2 , and $4 x$ the recommended rates. For formalin we used concentrations of $10,15,20$, and $25 \%$ $(v / v)$. All experiments were conducted twice. Dots represent the individual measurement for both experiments.

\section{Chlamydospores are sensitive to disinfectants in aqueous suspensions}

We obtained consistent results of approximately $1.10^{7} \mathrm{cfu}^{-\mathrm{g}^{-1}}$ for all water controls in all experiments. All concentrations tested for quaternary ammonium disinfectants were effective in annihilating all chlamydospores in the suspension at all rates and exposure times, except for Multisept that only failed at $0.25 x$ and short exposure times (Figure 3). Similar efficacies were obtained for Formo and Vanodine. In contrast, Hichlon70 was ineffective for all concentrations and time points tested, albeit that some reduction of cfu's was observed at the $1 x$ and $2 x$ rates and long exposure times. Also, formalin that is frequently applied in the field by farmers was fully effective at all concentrations tested even at $15 \mathrm{sec}$ exposure time and ethanol, routinely employed as disinfectant in the laboratory was fully effective at the $45 \%$ and $47.5 \%$ rate $(\mathrm{v} / \mathrm{v} \%)$, while lower concentration $(40 \%)$ required prolonged exposure times for full efficacy.

\section{Reduced efficacy of disinfectants to chlamydospores in soil}

The efficacy of all disinfectants on chlamydospores in soil was inadequate at the recommended rate (1x), except for Formo (Figure 4). At higher rates other disinfectants showed improved efficacies, but at the highest rate (4x), Hichlon 70, Vanodine, GUAA, Multisept and ethyl alcohol lacked sufficient efficacies at all exposure times. 


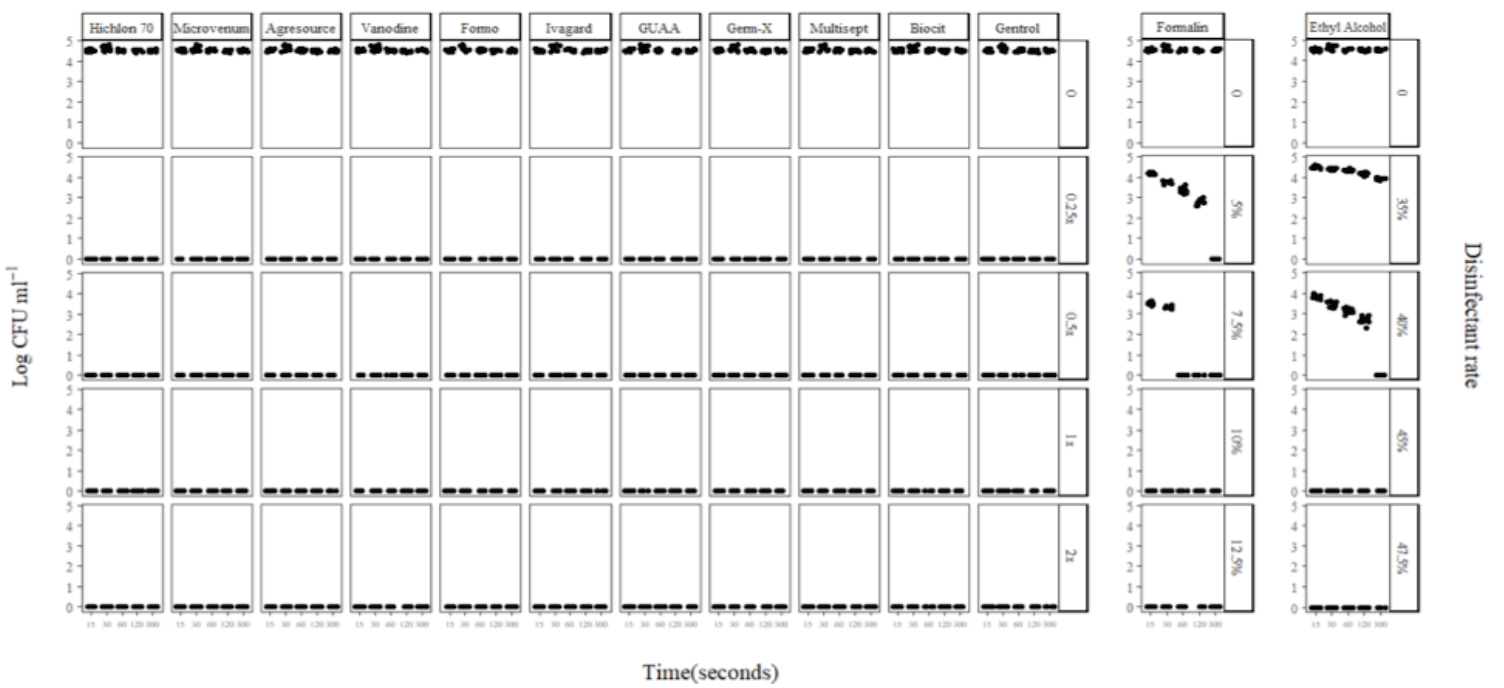

Figure 2. Efficacy of 13 disinfectants on Fusarium odoratissimum Tropical Race 4 (TR4) conidia ( $2 \times 10^{5}$. $\left.\mathrm{ml}^{-1}\right)$ at $0,0.25,0.5,1$ and $2 x$ the recommended rate and five exposure times $(15,30,60,120$ and 300 sec). For formalin and ethyl alcohol we used concentrations of 5, 7.5, 10 and $12.5 \%(\mathrm{v} / \mathrm{v})$ and 35,40 , 45 and $47.5 \%(\mathrm{v} / \mathrm{v})$, respectively. Data are expressed as average log transformed colony forming units (CFU) per applied ml TR4 spore suspension on petri dishes. All experiments were conducted twice and the means for both experiments are shown as dots.

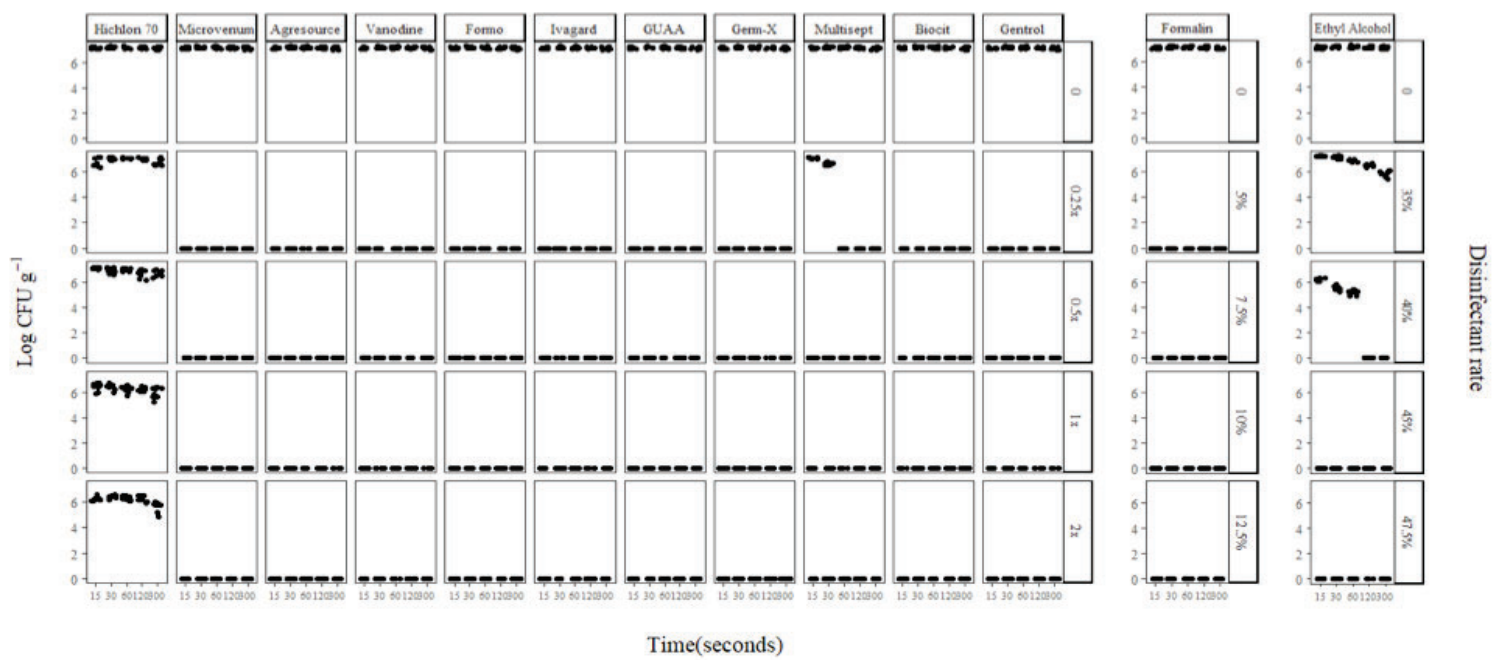

Figure 3. Efficacy of 13 disinfectants on Fusarium odoratissimum Tropical Race 4 (TR4) chlamydospores $\left(10^{6}\right.$ chlamydospores.gram of soil $\left.{ }^{-1}\right)$ in suspensions at $0,0.25,0.5,1$ and $2 x$ the recommended rate and five exposure times $(15,30,60,120$ and $300 \mathrm{sec})$. For formalin and ethyl alcohol we used concentrations of $5,7.5,10$ and $12.5 \%(\mathrm{v} / \mathrm{v})$ and $35,40,45$ and $47.5 \%(\mathrm{v} / \mathrm{v})$, respectively. Data were collected as log transformed colony forming units per gram of soil on petri plates. All experiments were conducted twice and the means for both experiments are shown as dots. 

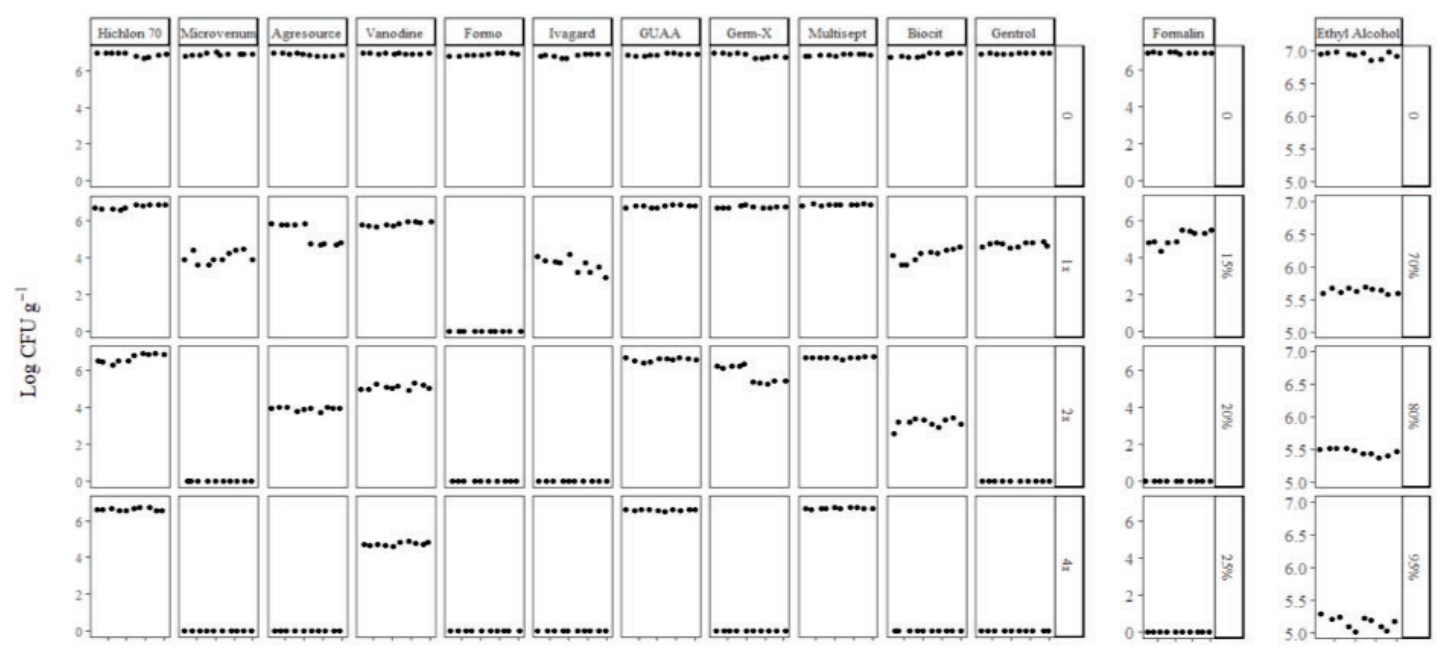

Figure 4. Efficacy of 13 disinfectants on Fusarium odoratissimum Tropical Race 4 (TR4) chlamydospores $\left(10^{6}\right.$ chlamydospores.gram of soil- $\left.{ }^{-1}\right)$ in soil at 1,2 and $4 x$ the recommended rate, an exposure time of $15 \mathrm{~s}$ and expressed as log transformed colony forming units per gram of soil on petri plates. For formalin and ethyl alcohol we used concentrations of 15, 20 and $25 \%(\mathrm{v} / \mathrm{v})$ and $70,80,95 \%(\mathrm{v} / \mathrm{v})$ rates per liter, respectively. All experiments were conducted twice. Dots represent the individual count for both experiments.

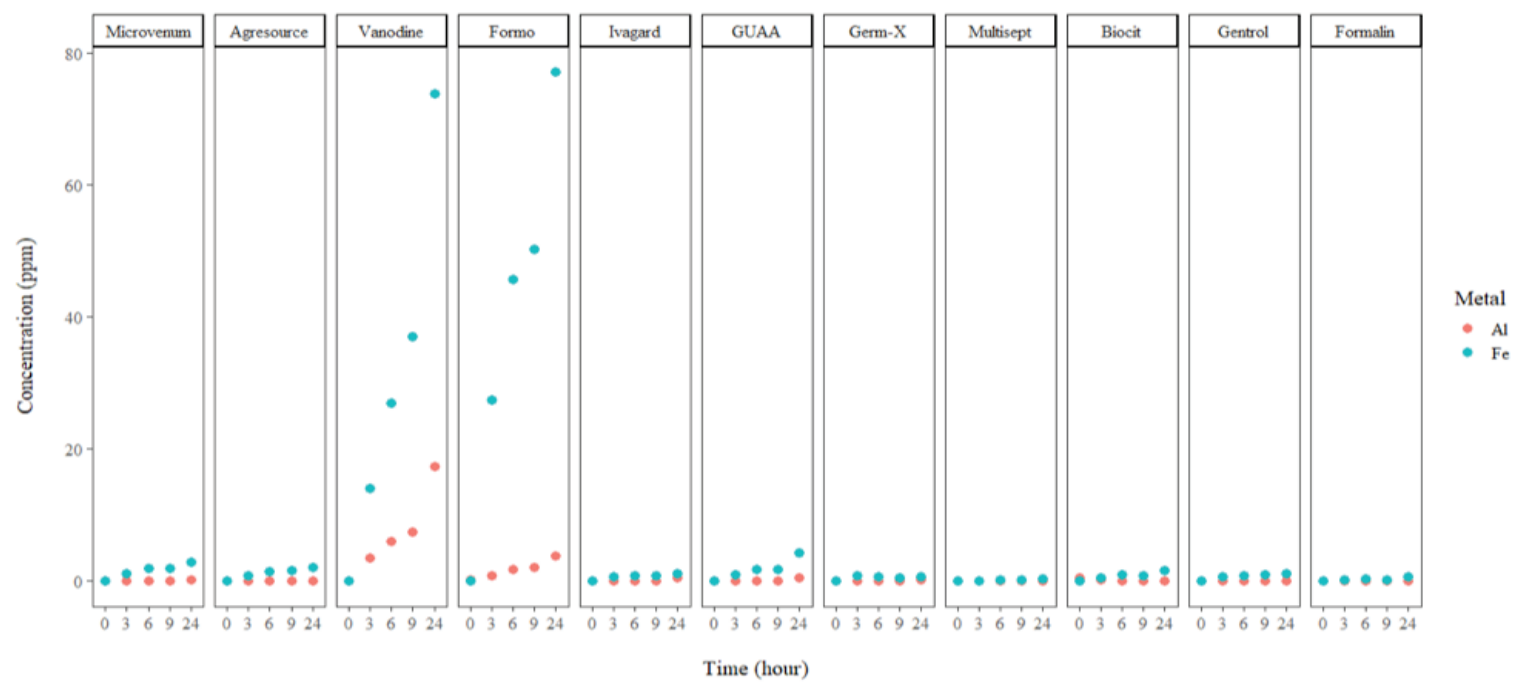

Figure 5. Corrosiveness of disinfectants towards aluminum (Al) and iron (Fe) after three, six, nine and 24 hours exposure to 11 disinfectants (1x dilutions) and expressed as concentrations of $\mathrm{Al}$ and Fe ions in parts per million (ppm). All experiments were conducted twice and the means for both experiments are shown as dots. 


\section{Disinfectants are corrosive to aluminum and iron}

Preference for specific disinfectants in farms also depends on the corrosiveness towards the surfaces of equipment and carriers. Therefore, we tested whether the 11 disinfectants were reactive to aluminum (Al) and iron (Fe). This revealed that Vanodine is the most reactive disinfectant for both Al and Fe (Figure 5), Formo showed corrosiveness towards Fe but hardly to Al and all other disinfectants did not affect either metals during the exposure times used.

In Table 2 we summarize the above data and conclude that nearly all disinfectants have appropriate efficacy for most TR4 propagules and limited corrosiveness for Al and Fe. However, once chlamydospores are embedded in soil, efficacies significantly drop and essentially only Formo, having corrosiveness activity toward Fe, showed the required capacity to kill TR4 even at short exposure times.

\section{Recording exposure to disinfectants under real time conditions}

The efficacy of disinfectants is also determined by exposure time. In all our experiments we used a minimal exposure time of $15 \mathrm{sec}$ and we monitored whether this minimum requirement is also practiced under practical field conditions. Table 3 displays the result of 400 individual measurements at quarantine units for persons or vehicles. For footbaths, the shortest and longest exposure times were $1.85 \mathrm{sec}$ and $7.54 \mathrm{sec}$, respectively, with an average of $3.42 \pm 0.82 \mathrm{sec}$. For vehicle tire baths, exposure ranged from 2.21 to $26.95 \mathrm{sec}$ depending on the type and size of the vehicle with an average of $5.07 \pm 3.08 \mathrm{sec}$. 
Table 2. Summary results of disinfectants tested in vitro at manufacturers' recommended concentrations against different propagules of Fusarium odoratissimum Tropical Race 4 (TR4) and their corrosiveness to metals.

\begin{tabular}{|c|c|c|c|c|c|}
\hline Disinfectant & Mycelium & Conidiospores & $\begin{array}{c}\text { Chlamydospores } \\
\text { (in suspension) }\end{array}$ & $\begin{array}{c}\text { Chlamydospores } \\
\text { (in soil) }\end{array}$ & Corrosiveness $^{\circ}$ \\
\hline Hichlon70 & NT & $t^{\mathrm{b}}$ & - & - & NT \\
\hline Microvenum & + & + & + & - & slight \\
\hline Agresource & + & + & + & - & slight \\
\hline Vanodine & + & + & + & - & high \\
\hline Formo & + & + & + & + & High $^{c}$ \\
\hline Ivagard & + & + & + & - & slight \\
\hline GUAA & - & + & + & - & slight \\
\hline Germ-X & + & + & + & - & slight \\
\hline Multisept & + & + & + & - & slight \\
\hline Biocit & + & + & + & - & slight \\
\hline Gentrol & + & + & + & - & slight \\
\hline Formalin $^{d}$ & + & + & + & - & slight \\
\hline Ethanole $^{\mathrm{e}}$ & NT & + & + & - & NT \\
\hline
\end{tabular}

${ }^{a}$ Corrosive capacity to both Fe and Al metals.

b "+" denotes total killing and "-" denotes slight or minimal killing of TR4 propagules. NT = not tested.

'Highly corrosive on Fe metal but slightly corrosive on Al.

${ }^{\mathrm{d}}$ Formalin tested at $15 \%(\mathrm{v} / \mathrm{v})$ rate per liter.

eEthanol tested at 45 and $70 \%$ (v/v) rate per liter for conidiospores, chlamydospores in suspension and chlamydospores in soil

Table 3. Real-time exposure times (in seconds) at disinfections units for Panama disease caused by Fusarium odoratissimum Tropical Race 4 (TR4) for persons and vehicles at an entry point of a large commercial plantation in Mindanao, the Philippines.

\begin{tabular}{lll}
\hline Parameter & Footwear bath & Tire bath \\
\hline Sample size & 200 & 200 \\
\hline Average exposure time & $3.42 \pm 0.82$ & $5.07 \pm 3.08$ \\
\hline Maximum exposure time & 7.54 & 26.95 \\
\hline Minimum exposure time & 1.85 & 2.21 \\
\hline
\end{tabular}

\section{Cost of quarantine baths}

The cost of installing and maintaining footwear and tire baths per year were calculated. As indicated in Table 4, installing one of these quarantine baths has an estimated cost of 11,500 US dollar. Annual maintenance costs per quarantine bath are 15,500 US dollar for the disinfectant and 3,500 US dollar for salary. For the plantation under study, with 18 quarantine baths, the total annual maintenance costs are estimated at 351,000 US dollar. 
Table 4. Estimated cost of quarantine baths per year in a big commercial banana plantation in Mindanao, Philippines.

\begin{tabular}{lll}
\hline \multirow{2}{*}{ Expense } & \multicolumn{2}{c}{ Estimated cost (US dollar ${ }^{\mathbf{a}}$ ) } \\
\cline { 2 - 3 } & Per quarantine bath & Entire plantation \\
\hline Disinfectant & $15,500.00$ & $288,000.00$ \\
\hline Labor maintenance & $3,500.00$ & $63,000.00$ \\
\hline Installation $^{\mathrm{c}}$ & $11,500.00$ & $207,000.00$ \\
\hline Total & $30,500.00$ & $558,000.00$ \\
\hline
\end{tabular}

aExchange value of 1 Philippine peso to 0.019218 US dollar

${ }^{\mathrm{b}}$ Total for 18 major footwear and tirebaths

'One time cost

\section{Discussion}

Pests and diseases are major bottlenecks for food production and security worldwide (Oerke and Dehne, 1997; Gurr et al., 2011; Oerke, 2006). Crop losses are prevented or reduced by either physical or biological methods, cultural practices or the use of pesticides. For soilborne pathogens, disease control is more complex as traditional methods had variable success (Katan, 2000; Weller et al., 2002) and chemical measures using methyl bromide, carbendazim or potassium phosphate (Herbert and Marx, 1990; Lakshamanan et al., 1987) are economically and environmentally not feasible. Banana is an important food security and cash crop, but is now in seriously threatened by TR4 causing Panama disease in Cavendish varieties as well as manifold locally preferred cultivars (Ploetz, 2015a; Garcia, 2019). The on-going dissemination of TR4 is associated with moving planting material (with attached soil), soil through farm workers and machineries or equipment and irrigation water (Dita et al., 2018). As there is no known effective and straightforward solution to eliminate the pathogen, particularly in soil, prevention of further spread is crucial. This necessitates the deployment of biosecurity measures within and between farms at a regional, international or continental scale. With this, verification of the efficacy of disinfectants that are used to decontaminate tools, footwear, machinery and equipment is necessary.

Here, we tested the efficacy of thirteen commercially available disinfectants against various propagules of TR4 at various concentrations and exposure length. We demonstrated that TR4 mycelia and conidia are sensitive to disinfectants. Effective concentrations are those at the manufacturer's recommended rates in all cases and in most cases even well below. Purified chlamydospores, despite their persistence in the soil, were also remarkably sensitive to the disinfectants tested in suspension. However, a considerable drop of efficacy was observed when disinfectants were tested against chlamydospores in soil. Overall, the diamidine-based disinfectant Formo (20\% active ingredient 2,2-dibromo-3-nitrilopropionamide) was most efficacious at $15 \mathrm{sec}$ exposure time. However, this compound has a high corrosive activity towards iron when compared to other disinfectants. Neither of the other disinfectants - 
with limited corrosive capacity - showed a sufficient efficacy towards chlamydospores in soil, except at extreme high concentrations (two to six percent concentration of disinfectant solution per liter).

Contrary to Nguyen et al. (2019), who tested disinfectants to prepared mixtures (1 soil : 20 disinfectant) of soil and chlamydospores of a race 1 strain and TR4 suspension and also reported a drop in efficacy, we tested chlamydospores suspensions as well as chlamydospores in soil. By producing chlamydospores in soil and testing these samples, we simulate the actual practices of routine disinfection in the field. Our findings support the results by Bennett et al. (2011) who showed that disinfectants were able to completely eliminate chlamydospores of $F$. oxysporum f.sp. vasinfectum (Fov) in suspensions but not directly in soil. Apparently, the soil - or any other organic material - reduces the access of disinfectants to chlamydospores (Moore and O'Neill, 2000; Ewart, 2001; Amass, 2001), likely by reduced effective concentrations or exclusion.

Organic matter also deactivates quaternary ammonium, iodine and ethanol containing disinfectants (Bennett et al., 2011; Dvorak, 2008; Ewart, 2001; Morley, 2002; Nguyen et al., 2019). This emphasizes the importance of pre-cleaning all surfaces from soil prior to disinfectant exposure (Ford, 1995; Amass et al., 2000; Amass et al., 2001). Hence, adopting a "come clean - go clean" strategy is required and essential to effectively use disinfectants.

Chlorine-releasing disinfectant (CRD) Clorox effectively eliminated Fov chlamydospores in soil (Bennett et al, 2011), but in our study it did not kill chlamydospores neither in suspension nor in soil. This opposing results might be due to variation of the target organisms, or the specific formulation and concentration of each product and experimental conditions. CRDs are supposed to be oxidizing agents that disrupt the cellular activity of proteins (Maris, 1995; Bloomfield, 1996), interrupt oxidative phosphorylation (Barrette et al., 1989) and other cellular membrane processes (Camper and McFeters, 1979). Therefore, these disinfectants need to be in direct contact with the spore structure. However, in the presence of soil or any other organic matter their efficacy is nullified (Ewart, 2001). This was also demonstrated by Cayanan et al. (2009) who showed that the free chlorine concentration rapidly declined in the presence of organic matter and other oxidizing agents when tested against $F$. oxysporum conidia in irrigation water. A higher concentration of chlorine ( $\geq 5 \mathrm{ppm})$ and longer exposure time ( $\geq 4 \mathrm{~min}$ ) was required to disinfect high organic load dam water (Scarlett et al., 2016). Hence, chlorine merely reduces pathogen concentrations, but does not eradicate fungal propagules from complex substrates (Cayanan et al., 2009; Scarlett et al., 2016).

Due to the TR4 pressure in Mindanao, farmers are desperate and use virtually anything to control Panama disease. This is the reason why even formalin ( $37 \%$ solution of formaldehyde gas in water) is frequently used despite its highly reactive and mutagenic properties (Power, 1990). Therefore, we included it in our study and observed that, indeed, it is effective against TR4 mycelia, conidiospores and chlamydospores in suspension but not against chlamydospores in soil. This can be due to over-dilution rendering it ineffective at $15 \%(\mathrm{v} / \mathrm{v})$ rate per liter. Thus, despite the fact that this disinfectant is sporicidal due to its ability to 
penetrate fungal spores (Sykes, 1970) and cross-linking to both proteins (Fraenkel-Conrat et al., 1945; Ewart, 2001) and nucleic acids (Fraenkel-Conrat, 1961; Maris, 1995), its application under field conditions is essentially useless. We observed similar dose-dependent efficacies for soil treatments with the quaternary ammonium disinfectants Microvenum, Agresource, Ivagard, Germ-X, Biocit and Gentrol.

We showed that an exposure time of $15 \mathrm{sec}$ is never met under field conditions. We cannot exclude efficacies at exposure times shorter than $15 \mathrm{sec}$, but the required experimental procedures to stop a treatment require a minimum of $15 \mathrm{sec}$ and hence we have taken this as a threshold. In any case, $15 \mathrm{sec}$ exposure time is far too short for any efficacy towards chlamydospores in a soil substrate. To support the claim of inadequacy of disinfectants for in-field sanitation, we monitored the minimum soaking times in foot and tire baths at farm gates and observed average exposure times of $1.85 \mathrm{sec}$ and $2.21 \mathrm{sec}$, respectively. The discrepancy between the required and observed exposure times in such sanitation baths, particularly under wet and muddy conditions, is nothing more than window dressing. This clearly hampers any quarantine measure which is implemented at high costs and does not stop the further on-farm, regional and international dispersal of TR4 (Zheng et al., 2018). We consider it striking that manufacturer's recommendations are limited to an optional concentration, but do not include minimal exposure times. Indeed, the required exposure times of various disinfectants vary, resulting in variable efficacies (MsDonnell and Russell, 1999; Ewart, 2001). Some have residual activity (quaternary ammonium) while others are volatile, leaving behind no residue (alcohol). Nguyen et al. (2019) also showed that increasing exposure time from $30 \mathrm{sec}$ up to 5 min enhances the efficacy of quaternary ammonium, bio-flavonoids, oxidizing agent or detergent-based disinfectants against a race 1 strain and TR4 chlamydospores in suspension. This accords with the observed decreasing efficacy of Farmcleanse to TR4 microconidia in a time series with decreasing exposure times from 15 min to $30 \mathrm{sec}$ (Meldrum et al., 2013). A minimum of 10 and 20 min exposure time is required to kill $>99 \%$ of $F$. oxysporum conidia, mycelium and chlamydospores, respectively, with 5 ppm chlorine in deionized water (Scarlett et al., 2016). The bactericidal action of diamidine containing disinfectant is exposure time dependent against Legionella pneumophila suspension tested at 6 and $12 \mu \mathrm{g} \cdot \mathrm{ml}^{-1}$ (Skaliy et al., 1980). The survival of Trichophyton mentagrophytes arthroconidia in suspension media was also exposure time dependent using a disinfectant containing $0.5 \%$ benzalkonium chloride (Gupta et al., 2001). James et al (2012) demonstrated that time is a critical factor for ethanol exposure of Phytophthora ramorum sporangia germination. The quaternary ammonium-based disinfectant Vesphene (Steris, USA) was only sufficiently effective against Coccidioides spp. arthroconidia in aqueous suspensions at an exposure time of at least $20 \mathrm{~min}$ (Vogler et al., 2015).

Taken together, our data clearly show that disinfectant efficacies depend on the propagule of the target pathogen, exposure time and concentration. We propose that, in the case of TR4, minimal exposure times with disinfectants should be enforced during entry of uninfected areas to exclude Panama disease incursions. Furthermore, manufacturers' recommendations should include minimal exposure times depending on weather and local 
conditions as well as data on corrosiveness. For instance, we showed that the diamidinesbased disinfectant Formo was efficacious but its corrosiveness towards iron is too high for practical use, and Vanodine also affected aluminum. Albeit that corrosiveness is a function of time, environmental conditions such as temperature also influence these processes (Southcott et al., 1982; Nguyen et al., 2019). Hence, farmers need to be better informed to enable critical decisions on disinfectant preferences. Foremost, however, any material, vehicle or footwear should be thoroughly cleaned from soil particles before entering disease free areas by pressurized spraying and (car) wash installations. This removes organic load accumulating and affecting the efficiency of disinfection baths. Alternatively, entry of nonsite tools, vehicles and footwear should be prohibited, which requires additional logistic arrangements for on-farm transportation.

In conclusion, the rational choice for appropriate disinfectants should be facilitated by accurate data on efficacies under various environmental/temporal conditions, costs and corrosiveness. Without such information, the implementation of effective quarantine measures is a pipe dream. The practical observations in the Philippines and elsewhere (Molina et al., 2009; Mostert et al., 2017; Zheng et al., 2018) are not promising as TR4 continues its dispersal to new locations (Chittarath et al., 2017; Garcia et al., 2014; Hung et al., 2017; Maymon et al., 2018; O’Neill et al., 2016; Ordóñez et al., 2016; Ploetz et al., 2015b; Thangavelu et al., 2019) which is driven by the flaws identified in this report as well as by the individual farm economies that enable or disable the procurement of costly disinfectants, and the installation and appropriate maintenance of sanitation units.

\section{Acknowledgements}

The authors gratefully thank Tadeco, Inc. Philippines for allowing us to conduct the test in their laboratory facility and premises as well as NEH Inc. Philippines and Unifrutti Tropical Philippines Inc. for providing us the disinfectants. MS is very grateful to Reagan Navarro for providing the protocol for the oxidative tests on metal corrosiveness conducted in the Tadeco chemistry laboratory. This work was funded by the Wageningen University Interdisciplinary Research and Education Fund (INREF) (www.panamadisease.org), Wageningen, The Netherlands. Banana research at WUR is supported by the Dutch Dioraphte Foundation endowed chair in Tropical Phytopathology of GHJK at the WUR-Laboratory of Phytopathology. 


\section{References}

Amass, S.F., B.D. Vyverberg, C.A. Dowell, C.D. Anderson, J.H. Stover, and D.J. Beaudry. (2000) Evaluating the efficacy of boot baths in biosecurity protocols. Swine health and production 8(4):169-173.

Amass, S.F., D. Ragland, and P. Spicer. (2001) Evaluation of peroxygen compound, Virkon S, as a boot bath disinfectant. Swine health and production 9(3):121-123.

Amorim, E., Ribeiro, L., Cordeiro, Z., de Oliveira e Silva, S. and Dita, M. (2009) Discrimination of banana genotypes for Fusarium wilt resistance in the greenhouse. $V$ International Symposium on Banana: ISHS-ProMusa Symposium on Global Perspectives on Asian Challenges 897.

Aurore, G., Parfait, B. and Fahrasmane, L. (2009) Bananas, raw materials for making processed food products Trends in Food Science \& Technology 20: 78-91.

Barrette, W.C. Jr., D.M. Hannum, W.D. Wheeler and J.K. Hurst. (1989) General mechanism for the bacterial toxicity of hypochlorous acid: abolition of ATP production. Biochemistry 28:9172-9178.

Bebber, D., Holmes, T. and Gurr, S.J. (2013) The global spread of crop pests and pathogens. Global Ecology and Biogeography 23:1398-1407.

Beckman, C.H. (1969) Plasticizing of walls and gel induction in banana root vessels infected with Fusarium oxysporum. Phytopathology 59:1477-1483.

Beckman, C.H. (1989) Colonization of the vascular system of plants by fungal wilt pathogens: a basis for modeling the interactions between host and parasite in time and space. In: Tjamos, E.C. and Beckman, C.H. (eds.). Vascular wilt diseases of plants. Springer-Verlag, Heidelberg, Berlin, pp.19-32.

Beckman, C.H. (1990) Host responses to the pathogen. In R.C. Ploetz (Ed.) Fusarium wilt of banana (pp. 107-114). St. paul:APS.

Bennett, R.S., W. O'Neill, L. Smith, and R.B. Hutmacher. (2011) Activity of Commercial Detergents Against Conidia and Chlamydospores of Fusarium oxysporum f.sp. vasinfectum. The Journal of Cotton Science 15:162-169.

Best, M., Satter, S.A. Springthorpe, V.S. and Kennedy, M.E. (1990) Journal of Clinical Microbiology 28(10): 2234-2239.

Bloomfield, S.F. (1996) Chlorine and iodine formulations, p.133-158. In J.M. Ascenzi (ed.), Handbook of disinfectants and antiseptics. Marcel Dekker, Inc. New York, NY, USA.

Camper, A.K. and G.A. McFeters. (1979) Chlorine injury and the enumeration of waterborne coliform bacteria. Applied Environmental Microbiology 37:633-641.

Cayanan, D.F., Zhang, P. Liu, W., Dixon, M. and Zheng, Y. (2009) Efficacy of Chlorine in Controlling Five Common Plant Pathogens. HortScience 44(1): 157-163.

Chakrabarti, A. (2013) Fusarium oxysporum: a "moving" view of pathogenicity. In B.A. Horwitz, P.K. Mukherjee, M. Mukherjee and C.P. Kubicek (Eds.). Genomics of soil-and plant-associated fungi (pp. 157-190). New York Dordrecht London: Springer.

Cheah, L-H., Mcneill, M.R., Marsh, A.T. Hedderley, D.I. (2009) Evaluation of disinfectant products for microbial decontamination of imported used footwear. New Zealand Plant Protection 62:130-135.

Chittarath, K., Mostert, D., Crew, K. S., Viljoen, A., Kong, G., Molina, G., \& Thomas, J. E. (2017). First report of Fusarium oxysporum f.sp. cubense tropical race 4 (VCG 01213/16) associated with 
Cavendish bananas in Laos. Plant Diesease

Chuchill, A.C. (2011) Mycosphaerella fijiensis, the black leaf streak pathogen of banana: progress towards understanding pathogen biology and detection, disease development, and the challenges of control. Molecular Plant Pathology 12(4): 307-328.

Dita, M.A., Barquero, M., Heck, D., Mizubuti, E.S.G., Staver, C.P. (2018) Fusarium Wilt of Banana: Current Knowledge on Epidemiology and Research Needs Towards Sustainable Disease Management. Frontiers in Plant Science: 9 (1468).

Dvorak, G. (2008) Disinfection 101. Center for Food Security and Public Health. lowa State University, USA.

Ewart,S.L(2001) Disinfectants and control ofenvironmental contamination. InSmith B.L(ed.) Largeanimal internal medicine:diseases of horses, cattle, sheep and goats. $3^{\text {rd }}$ ed. St. Louis: Mosby. pp1371-1380.

FAOSTAT. (2013) FAO statistical database.

Fisher, M.C., Henk, D.A., Briggs, C.J., Brownstein, J.S., Madoff, L.C., McCraw, S.L. and Gurr, S.J. (2012) Emerging fungal threats to animal, plant and ecosystem health. Nature 484:186-194.

Ford, W.B. (1995) Disinfection procedures for personnel and vehicles entering and leaving contaminated premises. Review of Science and Technology 142(2):393-401.

Fraenkel-Conrat, H. (1961) Chemical modification of viral ribonucleic acid (RNA). Alkylating agents. Biochimica et Biophysica Acta 49:169-180.

Fraenkel-Conrat, H.,M. Cooper, and H.S. Olcott. (1945) The reaction of formaldehyde with proteins. Journal of American Chemical Society 67:950-954.

FruitTrop. (2017) Banana-statistics. Fruit Trop, 248:86-87.

Garcia-Bastidas, F., Ordonez, N., Konkol, J., Al-Qasim, M., Nazer, Z., Abdelwali, M., Salem, N., Waalwijk, C., Ploetz, R., and Kema G.H.J. (2014) First report of Fusarium oxysporum f.sp. cubense tropical race 4 associated with Panama disease in banana outside southeast Asia. Plant disease 98 (5): 694.

Gehr, R., Wagner, M., Veerasubramanian, P. and Payment, P. (2003) Disinfection efficiency of peracetic acid, UV, and ozone after enhanced primary treatment of municipal wastewater. Water Research 37:4573-4586.

Gilchrist, J.E., Campbell, J.E., Donnelly, C.B., Peeler, J.T. and Delaney, J.M. (1973) Spiral plate method for bacterial determination. Applied Microbiology 25 (2): 244-252.

Gupta, A.K., I. Ahmad \& R. C. Summerbell (2001) Comparative efficacies of commonly used disinfectants and antifungal pharmaceutical spray preparations against dermatophytic fungi. Medical Mycology 39:4,321-328.

Gurr, S., Samalova, M., and Fisher, M. (2011) The rise and rise of emerging infectious fungi challenges food security and ecosystem health. Fungal Biology Reviews 25(4): 181-188.

Herbert and Marx, 1990 J.A. Herbert and D. Marx, Short-term control of Panama disease in South Africa. Phytophylactica 22: 339-340.

Hung, T. N., Hung, N. Q., Mostert, D., Viljoen, A., Chao, C. P., \& Molina, G. (2017). First report of Fusarium wilt on Cavendish bananas, caused by Fusarium oxysporum f.sp. cubense tropical race 4 (VCG 01213/16), in Vietnam. Plant Disease

James, D., Varga, A., Becker, E., Sumampong, G., Bailey, K., Elliott, M., Masri, S. and Shamoun, S.F. (2012) Screening of several disinfectants to assess their efficacy in controlling mycelia growth, sporangia germination, and recovery of viable Phytophthora ramorum. Crop Protection 42:186-192.

Komada, H. (1975) Development of a selective medium for quantitative isolation of Fusarium oxysporum from natural soil. Review of Plant Protection Research 8: 114-124.

Katan, J. (2000) Physical and cultural methods for the management of soil-borne pathogens. Crop 
Protection 19:725-731.

Lakshmanan, P., Selvaraj, P. and Mohan, S. (1987) Efficiency of different methods for the control of Panama disease. Tropical Pest Management 33: 373-376.

Maris, P. (1995) Modes of action of disinfectants. Revue scientifique et technique 14(1) 47-55.

Maryani, N., Lombard, L., Poerba, Y., Subandiyah, S., Crous, P. and Kema, G. (2019) Phylogeny and genetic diversity of the banana Fusarium wilt pathogen Fusarium oxysporum f.sp. cubense in the Indonesian centre of origin. Studies in Mycology 92:155-194.

Maymon, M. Shpatz, U., Harel, , Y.M., Levy, E., Elkind, , G., Teverovsky, E.,..... Israeli, Y. and Freeman, S. (2018) First Report of Fusarium oxysporum f. sp. Cubense Tropical Race 4 Causing Fusarium Wilt of Cavendish Bananas in Israel. Plant Disease 102 12: 2655.

Meldrum, R.A., Daly, A.M., Tran-Nguyen, L.T.T., Aitken, E.A.B. (2013) The effect of surface sterilants on sporegermination of Fusarium oxysporumf.sp. cubense tropical race 4.Crop Protection 54:194-198.

Molina, A.B., Fabregar, E., Sinohin, V.G., Yi, G., and Viljoen, A. (2009) Recent occurrence of Fusarium oxysporum f.sp. cubense tropical Race 4 in Asia. Acta Horticulturae 828:109-115.

Moore, N.Y., Pegg, K.G., Smith, L.J., Langdon, P.W., Bentley, S. and Smith, M.K. (2001) Fusarium wilt of banana in Australia. Pages 64-75 in: Banana Fusarium Wilt Management: Towards Sustainable Cultivation., A.B. Molina, N.H. Masdek and K.W.Liew, eds. International Network for the Improvement of Banana and Plantain - Asia and the Pacific Network, Los Banos, Philippines.

Morley, P.S. (2002) Biosecurity of veterinary practices. The Veterinary Clinics Food Animal Practice 18:133-55.

Mostert, D., Molina, A. B., Daniells, J., Fourie, G., Hermanto, C., Chao, C. P., . . Viljoen, A. (2017). The distribution and host range of the banana Fusarium wilt fungus, Fusarium oxysporum f.sp. cubense, in Asia. PLoS One 12(7): 1-24.

MsDonnell, G. and Russell, A.D. (1999) Antiseptics and disinfectants: Activity, Action and Resistance. Clinical Microbiology reviews 147-179.

Nel, B., Steinberg, C., Labuschagne, N., Viljoen, A. (2007) Evaluation of fungicides and sterilants for potential application in the management of Fusarium wilt of banana. Crop Protection 26: 697-705.

Nguyen, T.V., Tran-Nguyen, L.T.T., Wright, C.L. Trevorrow, P. and Grice. K. (2019) Evaluation of the Efficacy of Commercial Disinfectants Against Fusarium oxysporum f. sp. cubense Race 1 and Tropical Race 4 Propagules.

Plant Disease 103(4):721-728.

Oerke, E.C. (2006) Crop losses to pests. Journal of Agricultural Science 144:31-43.

Oerke, EC. \& Dehne, HW.(1997) Global crop production and the efficacy of crop protection - current situation and future trends. European Journal of Plant Pathology 103: 203.

O'Neill, W.T., Henderson, J.A., Pattemore, C. et al. (2016) Detection of Fusarium oxysporum f. sp. cubense tropical race 4 strain in northern Queensland. Australasian Plant Disease Notes 11(33).

Ordonez N, Seidl MF, Waalwijk C, Drenth A, Kilian A, Thomma BPHJ, et al. (2015) Worse Comes to Worst: Bananas and Panama Disease -When Plant and Pathogen Clones Meet. PLoS Pathogen 11(11).

Ordoñez, N., García-Bastidas F., Laghari, H. B. ., Akkary, M. Y., Harfouche, E. N., and al Awar, B. N., and Kema, G. H. J. (2016) First report of Fusarium oxysporum f.sp. cubense tropical race 4 causing Panama disease in Cavendish bananas in Pakistan and Lebanon. Disease Notes 100 (1): 209

Perez-Vicente, L.P. (2004) Fusarium wilt (Panama Disease) of bananas: an updating review of the current knowledge on the disease and its causal agent. ACORBAT.

Ploetz, R.C. (2015a) Fusarium wilt of banana. Phytopathology 105:1512-1521. 
Ploetz, R., Freeman, S., Konkol, J., Al-bed, A., Naser, Z., Shalan, K., Barakat, R., and Israeli, Y. (2015b) Tropical race 4 of Panama disease in the Middle East. Phytoparasitica 43:283-293.

Ploetz, R.C., Thomas, J.E. and Slabaugh, W.R. (2003) Diseases of banana and plantains. In: Ploetz, R.C (ed.) CAB International. Diseases of Tropical Fruit Crops.

Power, E.G.M. (1990) Aldehydes as biocides. Progress in Medicinal Chemistry 34:149-201.

Russell, A.D. (2002) Antibiotic and biocide resistance in bacteria: comments and conclusions. Journal Applied Microbiology. Symp. Supp. 92:171-173.

Rutala WA, Weber DJ, Healthcare Infection Control Practices Advisory Committee (HICPAC). Guideline for disinfection and sterilization in healthcare facilities. (2008) Atlanta, GA: U.S. Department of Health and Human Services, Centers for Disease Control and Prevention; 2008.

Scarlett, K., Collins, D., Tesoriero, L., Jewell, L., van Ogtrop, F. and Daniel, R. (2016) Efficacy of chlorine, chlorine dioxide and ultraviolet radiation as disinfectants against plant pathogens in irrigation water. European Journal of Plant Pathology 145: 27-38.

Skaliy, P., Thompson, T.A., Gorman, G.W., Morris, G.K., McEachern, H.V. and Mackel, D.C. (1980) Laboratory Studies of Disinfectants Against Legionella pneumophila. Applied and Environmental Microbiology 40(4): 697-700.

Southcott, B.A. Boyd, J.W., Green, W., Ho, M. and Gray, V. (1982) Fisheries and Aquatic Sciences Canadian Technical Report No. 1148. Canada.

Stover, R.H. (1962) Fusarial wilt (Panama disease) of bananas and other Musa species. Kew,UK: Commonwealth Mycological Institute.

Thangavelu, R., Mostert, D., Gopi, M., Ganga Devi, P., Padmanaban, B., Molina, A.B. and Viljoen, A. (2019) First detection of Fusarium oxysporum f. sp. cubense tropical race 4 (TR4) on Cavendish banana in India. European Journal of Plant Pathology.

VanderMolen, G.E., Beckman, C.H. and Rodehorst, E. (1977) Vascular gelation: a general response phenomenon following infection. Physiological and Plant Pathology 11: 95-110.

Vogler, A. J., Nottingham, R., Parise, K.L., Keim, P., and Barker, B.M. (2015) Effective Disinfectants for Coccidiodes immitis and C. posadasil. Applied Biosafety 20 (3): 154-158.

Waite, B. H., \& Stover, R. H. (1960) Studies on Fusarium wilt of bananas, VI. Variability and cultivar concept in Fusarium oxysporum f. sp. cubense. Canadian Journal of Botany 38, 985-994.

Weller, D. M. Raaijmakers, J. M., McSpadden, B. B., Thomashow, G.L. S. (2002) Microbial populations responsible for specific Soil suppressiveness to plant pathogens. Annual Review of Phytopathology 40:1 309-348 .

Zheng, SJ., Garcia-Bastidas, F., Li, X., Zeng, L., Bai, T., Xu, S., Li, H., Fu, G., Yu, Y., Yang, L., Nguyen, HC., Dounneuang, D., Khaing, A., Drenth, A., Seidl, M., Meijer, H.J.G., and Kema, G.H.J. (2018) New Geographical Insights of the Latest Expansion of Fusarium oxysporum f.sp. cubense Tropical Race 4 Into the Greater Mekong Subregion. Frontiers in Plant Science. 

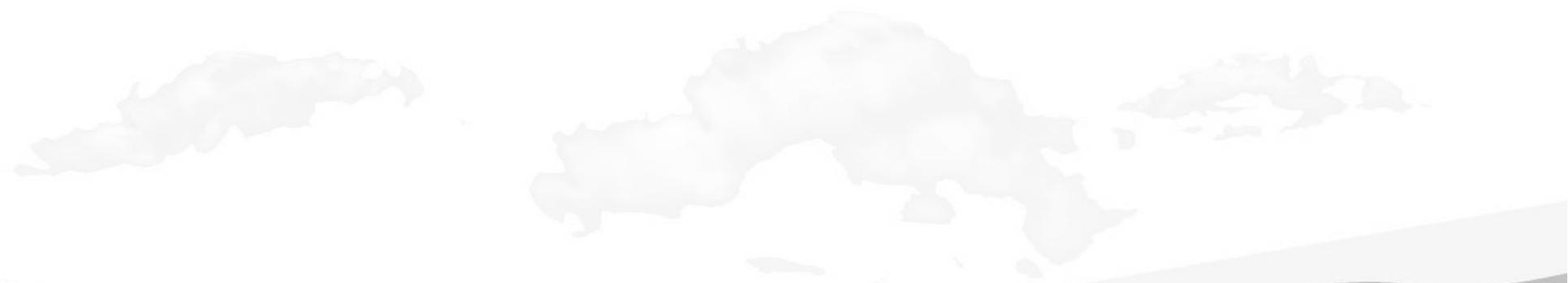

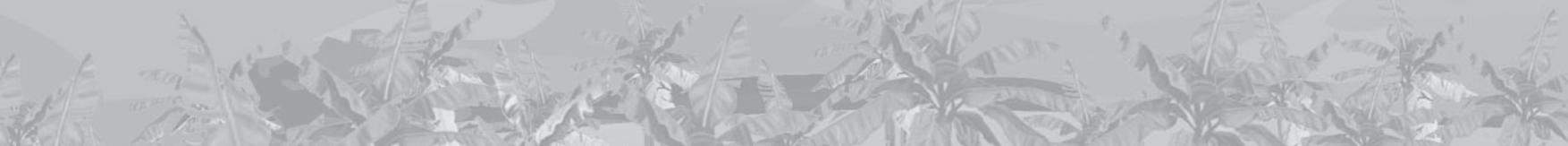

1.

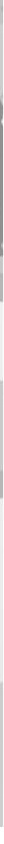




\section{CHAPTER 5}

\section{Anaerobic soil disinfestation controls Panama disease caused by Tropical Race 4 in Cavendish bananas}

Salacinas, M.S., Meints, H., Runia, W., Kastelein, P., Corcolon, B.M., Rebuta, A.M., Mora, J, Gaon, M.B., Tuba, J., Trüggelmann, L., Narreto, L., Peñalosa, W., Chavez, S.M., Meijer, H.J.G., and Kema, G.H.J. 


\section{Abstract}

The current threat of Panama disease is reminiscent of the previous epidemic that wiped out the Gros Michel based banana production in Central America. The so-called tropical race 4 (TR4) represents a genotype of the recently identified new species Fusarium odoratissimum which is pathogenic on Cavendish bananas. This clone dominate the global export but are also important for many local markets. Here, we report an investigation on the potential of anaerobic soil disinfestation (ASD), as a biological option for Panama disease management, using two commercial organic amendments. First, ASD was tested under laboratory conditions and gas production was monitored during the experiment. Besides rapid oxygen reduction, several gases such as carbon dioxide, methane and hydrogen sulfide, and volatile fatty acids, such as acetic, propionic and butyric acid escalated during the experiment. After four weeks, the viability of TR4 chlamydospores was reduced to $0.01 \%$ of the control in plastic containers. Upon these results, we implemented a pilot study under field and laboratory conditions in the banana production region of Mindanao, The Philippines. Here, ASD was prolonged to eight weeks, which resulted in hundred-fold reductions of the initial TR4 inoculum levels. Treated plots were subsequently replanted to the Cavendish variety "Williams" and recurrence of Panama disease was monitored for one crop cycle. Compared to controls, the incidence of recurring Panama disease was significantly reduced showing that ASD has potential for disease management under field conditions.

Keywords: banana, Fusarium wilt, Panama disease, tropical race 4, disease management, anaerobic soil disinfestation 


\section{Introduction}

Panama disease or Fusarium wilt caused by the soil-borne fungal pathogen Fusarium odoratissimum, popularly called Tropical Race 4 (TR4), is posing a serious threat to global banana production (Waite and Stover, 1960; Ploetz, 2015a). The emergence of this strain which is pathogenic on the globally grown "Cavendish" varieties, delimits banana production intended for domestic and international trade (Molina et al., 2009; Ordoñez et al., 2015; Ploetz et al., 2015). Recent disease outbreaks (Chittarath et al., 2017; García-Bastidas et al., 2015; Hung et al., 2017; Mostert et al., 2017; O’Neill et al., 2016; Ordóñez et al., 2016; Ordóñez et al., 2015; Maymon et al., 2018; Zheng et al., 2018) underscore its danger and continued proliferation of TR4 in countries such as China and India (Lian et al., 2009; Thangavelu et al., 2019), which are among the largest global banana producers, Australia (O'Neill et al., 2016) which has the excellent quarantine measures and the recent bankruptcy of an industrial plantation in Mozambique (Anonymous, 2013), and recent incursion in Colombia (https://www.sciencemag.org/news/2019/07/devastating-banana-disease-mayhave-reached-latin-america-could-drive-global-prices) demonstrate the overall failure of containment strategies. The dissemination of this banana pathogen is enhanced by its broad host range, including many sweet dessert and cooking bananas destined for domestic markets (Garcia et al., 2019). Future economic damage will be disastrous once this pathogen impacts the major export banana production plantations in Latin America and hits countries that rely on banana as a staple crop (Ploetz, 2000; 2006). Clearly, the socio-economic impact increases with extended disease spread, particularly since there are currently no widely implemented effective and long-term control strategies available. Moreover, contrary to the past when "Cavendish" varieties saved the industry due to their resistance to Fusarium spp. - collectively called race 1 strains - that caused the epic Panama disease epidemic in the previous century, there are currently no economically viable substitutes. Albeit, TR4resistant bananas can be engineered (Dale et al., 2017). However, genetically modified bananas are not generally accepted in the market (Raman, 2017). Traditional breeding is also a long-term effort, which hitherto did not deliver competitive new banana cultivars. This resulted in a deadlock for banana improvement that paves the way to alternatives, such as Giant Cavendish Tissue Culture Variants (GCTCV), with reduced susceptibility to TR4 (Hwang et al., 2004, Mostert et al., 2017). Such genotypes, however, lack immunity to TR4 and show variable field performance (Dale et al., 2017) and hence, should only be considered as a temporary solution under specific conditions that ought to be accompanied by a range of additional control and quarantine measures. However, in practice, deploying these clones results in reduced attention for quarantine, which only worsens the situation. Therefore, short-term management options should focus on prevention by implementing adequate quarantine measures (Salacinas et al., 2019), and developing methods that nullify or reduce the soil-borne inoculum to slow-down the epidemic.

The majority of diseases caused by soil-borne pathogens is too complex to be controlled by traditional methods such as inundation, soil steaming or solarisation, crop rotation, destruction of crop residues by e.g. burning or the elimination of plants that may act as 
alternative hosts (Stover, 1979; Katan, 2000; Weller et al., 2002; see Chapter 3). Chemical measures, such as the application of methyl-bromide (Herbert and Marx, 1990), carbendazim or potassium phosphonate (Lakshamanan et al., 1986) are effective against soil-borne pathogens but are hazardous to farm workers and the environment, hence incompatible with sustainable agriculture (Prather, et al., 1984; Ristaino and Thomas, 1997; Duniway, 2002; Subbarao, 2002; Fravel et al., 2003). Fusarium wilts are increasing in importance in various annual crops (Cianchetta and Davis, 2015; Carvalho et al., 2015; Gilardi et al., 2017; Imazaki and Kadota, 2019; Koike and Gordon, 2015), but even more complex in perennial cropping systems such as banana as there are no known straightforward, long-term control measures available (Pegg et al., 1996; Ploetz, 1990). Presently, Panama disease management includes chopping down infected banana plants followed by rice hull burning (e.g. in the Philippines), or just leave the plant standing until it dies (e.g. China). However, there are no publicly available data showing the (economic) efficacy of these measures (Salacinas et al., 2019). In Australia a recent TR4 incursion in Northern Queensland (O'Neill et al., 2016), prompted drastic measures including the destruction of all banana plants (both infected and healthy), followed by a farm buy-out. For secondary incursions in the same region farm operations ceased, many infected and surrounding plants were destroyed, accesses to the property was restricted and regulations on the movement of banana material and associated machinery and equipment from the affected farm to other banana producing areas in Queensland were imposed by the Australian authorities (Australia Department of Agriculture and Water Resources).

Due to the urgency and overall management inadequacy, manifold alternative methods and products are being advocated such as the use of various mixes of beneficial microbes. Albeit that the far majority of these products never reach the scientific literature as their efficacy cannot unequivocally be demonstrated, Fu et al. (2016) showed that consecutive applications of biofertilizer (BIO) controlled Panama disease in newly established Chinese banana farms. Furthermore, the use of antagonistic microorganisms to create TR4 suppressive soils was described with application of actinomycetes (Meredith, 1943; 1946; Cao et al., 2005), Pseudomonas fluorescens (Akila et al., 2011; Nel et al., 2006; Raguchander et al., 1997; Saravanan et al., 2003; Sivamani and Gnanamanickam, 1988), P. aeruginosa (Saravanan and Muthusamy, 2006), Trichoderma viride (Raguchander et al., 1997; Thangavelu and Mustaffa, 2010), T. harzianum (Thangavelu et al., 2003), Streptomyces spp. (Getha and Vikineswary, 2002; Getha et al., 2005), Bacillus spp. (Akila et al., 2011; Yuan et al., 2012), Serratia spp. (Ting et al., 2008), and Penicillium citrinum (Ting et al., 2012). In addition, nonpathogenic Fusarium strains have been investigated as potential competitors of pathogenic strains (Forsyth et al., 2006; Gerlach et al., 1999; Nel et al., 2006; Thangavelu and Jayanthi, 2009; Ting et al., 2009). Generally, these rhizosphere microorganisms could be potentially effective for Panama disease control through competition in the soil, root surface and plant tissues as they compete for nutrients, oxygen and space, physically destruct the fungal cell wall or (in)directly induce systemic acquired resistance (Fravel et al., 2003). Despite promising efficacies in trial setups, many of these organisms fail under modern production environments in the field or are not eligible for large scale production (Belgrove et al., 2011). Crop rotation would be another viable contribution to Panama disease management but is 
alien to traditional multiyear banana cropping. Therefore, alternating crops such as Chinese leek may have inhibitory effects on TR4, but the efficacy under contemporary production conditions has still to be evaluated (Huang et al., 2012).

Inundation was commonly practiced to reduce pathogen inoculum during the previous Panama disease epidemic in Central America (Marquardt, 2001). Anaerobic soil disinfestation (ASD) is an alternative method and comprises the addition of organic products as carbon source to a humid soil, proper mixing and compressing of the soil before covering the treated area with airtight foil (Blok et al., 2000; Momma et al., 2005; Momma et al., 2006; Momma et al., 2007; Butler et al, 2012a). The combination of oxygen depletion and the production of toxic volatiles from anaerobic decomposition as well as the increase in facultative and strict anaerobic microorganisms that act as antagonists results in the reduction of soil-borne pathogens (Blok et al., 2000; Momma et al., 2006; Momma, 2008). This soil amendment strategy was effective in the management of replanting disease in asparagus (Blok et al., 2000; Lamers et al., 2000), and Fusarium wilt in tomato (Mowlick et al., 2012a) and spinach (Mowlick et al., 2012b). Various other soil-borne diseases were also successfully controlled, including Verticillium wilt in strawberry (Lamers et al., 2010; Thanning and Gerhardson, 2001), Rhizoctonia damping-off in sugar beet (Blok et al., 2000) and Sclerotinia sclerotiorum and S. cepivorum white mould and root rot in onions, respectively (Lamers et al., 2010; Thanning and Gerhardson, 2001). In addition, ASD is effective against bacterial wilts in potato (Messiha et. al., 2007), several species of nematodes (Lamers et al., 2010; Goud et al., 2003) and weeds such as creeping yellow field cress (Rorippa sylvestris) (Jansma et al., 2001) and snow-thistle (Sonchus arvensis) (Bleeker, 2008). Currently, ASD is used as an alternative for soil fumigation in Japan (Shinmura, 2004; Momma et al., 2013), the Netherlands (Blok et al., 2000; Messiha et. al., 2007; Goud et al., 2003) and the USA (Butler et al., 2012a) under greenhouse and field production environments.

Hence, we considered it inevitable to test ASD for its efficacy on Panama disease caused by TR4 in Cavendish bananas. However, rather than applying crop residues or undefined organic wastes, we applied standardized commercially available organic products in ASD trials as a management strategy for Panama disease in banana under laboratory and field conditions.

\section{Materials and methods}

\section{Inoculum production and management}

Experiments were conducted in The Netherlands and the Philippines. We used the $F$. odortissimum II-5 TR4 reference isolate from Indonesia and its local clone isolate Phil 2.6c from the Philippines (Ordoñez et al., 2015) in laboratory trials and the latter for field trials in Mindanao, The Philippines. Chlamydospores were produced following the procedure described by Amorim et al. (2009) with some modifications as described in Chapter 4 (this thesis). The presence of chlamydospores in the soil substrate was determined through microscopic observation and the density of the inoculum was determined by the spiral plate 
method (Gilchrist et al., 1973). For both the laboratory and field experiments, we prepared nylon mesh bags containing $15 \mathrm{~g}$ TR4 chlamydospores in soil $\left(1.10^{7}\right.$ spores.gram $\left.{ }^{-1}\right)$, which were placed in the containers ( 1 per container) at a depth of approximately $6-9 \mathrm{~cm}$. In the laboratory trials the containers were closed with a lid, whereas in the field trial containers were left open and buried in the soil to undergo ASD (Figure S1). Each nylon mesh bag was connected to a $25 \mathrm{~cm}$ long galvanized iron wire $(\mathrm{N}=16)$ for easy removal after the treatment. Subsequently, each nylon mesh bag was immediately placed in a $50 \mathrm{ml}$ polypropylene plastic tube and brought to the laboratory for analyses.

\section{Anaerobic soil disinfestation product}

In all ASD trials we used three commercial formulations of Herbie ${ }^{\circ}$, which is a compact biological product composed of potato, wheat, soy and/or maize granules and has a consistent quality and composition (C:N:P:S ratio) (Thatchtec B.V., Wageningen, The Netherlands). In the laboratory experiment in The Netherlands we used Herbie 72 and in the field and accompanying laboratory test in the Philippines we used Herbie 25 and Herbie 82 , which have the same ingredients but slightly different formulations.

\section{Laboratory experiments}

The Dutch experiment was conducted at Wageningen University and Research (WUR), Applied Plant Research, in Lelystad and commenced in April 2014. The used soil had a pH of 6.5 , an organic matter content of $4.3 \%$ and was composed of clay (7\%), silt (17\%) and sand $(71 \%)$ and was moistened to $15-20 \%$ soil capacity, which is optimal for the ASD process (Runia et al., 2014). Herbie 72 was added at a rate of $4 \mathrm{~g}$ crude protein per liter of soil and was thoroughly mixed prior to closing the containers and thereby starting the experiments. Five treatments were distributed over $11 \mathrm{~L}$ polypropylene containers (Table 1), with 20 containers per treatment, which were then sealed off with the airtight lid (except ventilating controls) and placed in a ventilated climate room at $24^{\circ} \mathrm{C}$ with a constant relative humidity of $\sim 70 \%$ for four weeks. Each week, five randomly selected containers per treatment were opened to stop ASD and determine the quantity of viable TR4 propagules by spiral plating. In addition, throughout the experiments in The Netherlands, we sampled gases and determined the concentration of volatile fatty acids. Oxygen was measured with a portable gas monitor based on electro-chemical sensor technology (type Impact Pro, Zellweger Analytics Ltd). The gases $\mathrm{H}_{2} \mathrm{~S}, \mathrm{CH}_{4}, \mathrm{CO}_{2}, \mathrm{NH}_{3}$, and $\mathrm{N}_{2} \mathrm{O}$ were measured with an infrared photo acoustic spectrophotometer (Innova 1412, LumaSense Technologies). Volatile fatty acids were measured by taking 10 subsamples ( $50 \mathrm{~g}$ each) using an auger to make up a single sample. After mixing, a subsample of $50 \mathrm{~g}$ was mixed with $100 \mathrm{~mL}$ demineralized water and then shaken for 30 mins followed by centrifugation at 1,957 x g for 25 mins. Subsequently, 0.5 $\mathrm{ml}$ of supernatant was transferred to a $1.5 \mathrm{ml}$ Eppendorf tube that was supplemented with $0.5 \mathrm{ml}$ of $0.1 \mathrm{M}$ ortho-phosphoric acid and $0.5 \mathrm{ml} 19.7 \mathrm{mmol}^{-I^{-1}}$ isocapronic acid as internal standard. The fatty acids were separated and detected using gas chromatography - flame ionization detector (GC-FID). The system was based on Grace EC-1000 gas chromatography 
(MZ-Analysentechnik $\mathrm{GmbH}$, Germany) with a column length of $30 \mathrm{~m}, 0.53 \mathrm{~mm}$ internal diameter and DB-5 column with $0.2 \mu \mathrm{m}$ film thickness (J\&W Scientific, Folsom, California). Helium was used as carrier gas at a flow rate of $1.3 \mathrm{ml} \mathrm{min}^{-1}$. Quantification was based on comparison with chemical standards after internal standard correction.

Table 1. Anaerobic soil disinfestation (ASD) to reduce Fusarium odoratissimum, Tropical Race 4 (TR4), inoculum in soil. Various laboratory and field ASD treatments were conducted to determine the efficacy of Herbie products against TR4 chlamydospores.

\begin{tabular}{llc}
\hline Experimental group & Treatment & Duration (weeks) \\
\hline Laboratory experiment: Wageningen & + TR4, - Herbie, sealed & \\
University and Research & + TR4, + Herbie, unsealed & 4 \\
The Netherlands & + TR4, + Herbie, sealed & \\
& + TR4, - Herbie, unsealed & \\
& - TR4, - Herbie, unsealed & \\
\hline Laboratory experiment: Philippines & + TR4, + Herbie 25 & \\
& + TR4, + Herbie 82 & \\
& + TR4, + Herbie 25 and 82 & \\
& + TR4, - Herbie, unsealed & \\
& - TR4, - Herbie, unsealed & \\
& + TR4, + Herbie 25 and 82 gross plot & \\
& + TR4, + Herbie 25 and 82 net plot & \\
Field Experiment: Philippines & + TR4, - Herbie, unsealed & \\
& - TR4, - Herbie, unsealed & \\
\hline
\end{tabular}

In the Philippines, the laboratory trials were conducted at the sites of the field trials using naturally infested soil (Figure 1; Table S1). Containers were filled with either infested soil amended with Herbie $25\left(3 \mathrm{~kg} \cdot \mathrm{m}^{-2}\right)$, or infested soil amended with Herbie $82\left(4.5 \mathrm{~kg} \cdot \mathrm{m}^{-2}\right)$ or infested soil amended with a mixture of Herbie ${ }^{\circ} 25$ and Herbie ${ }^{\circ} 82$ at $3 \mathrm{~kg} . \mathrm{m}^{-2}$ and $4.5 \mathrm{~kg} . \mathrm{m}^{-}$ 2 , respectively. We used artificially inoculated soil $\left(1.10^{7}\right.$ spores.gram $\left.{ }^{-1}\right)$ as positive control and autoclaved soil as negative control. Each treatment comprised three containers. To each container, a nylon mesh bag with Phil 2.6c TR4 chlamydospores suspended in the natural soils was placed at the bottom, which were then tightly sealed with a lid and placed in a compartment at room temperature $\left( \pm 27^{\circ} \mathrm{C}\right)$ (Figure S1). After eight weeks, the containers were opened to stop ASD and determine the quantity of viable TR4 propagules by spiral plating method.

\section{Field experiment}

The field trial was performed at three commercial Cavendish banana producing farms located in Davao del Norte, Sarangani and Bukidnon (Figure 1). At each farm two experimental plots were designed, six plots in total. All these sites were previously identified for high natural infestation of TR4, which we verified with molecular diagnostics (Figure S2). The field trial 
was conducted for one cropping cycle between October 2016 and July 2017. The soil at the farms is diverse and varies from heavy clay to sandy soils (Table S1). The moisture content of the soil at each trial site was considered wet enough for an optimal ASD process. During the execution of the trial at Farm 2-B the soil was drying, and we therefore irrigated until field capacity to ensure an efficient ASD. During the entire trialling process, we recorded the atmospheric temperature (average temperature) at all sites which were $27.7^{\circ} \mathrm{C}$ at farm 1 , $26.9^{\circ}$ at farm $2 \mathrm{~A}, 27.5^{\circ} \mathrm{C}$ at farm $2 \mathrm{~B}$ and $27.1^{\circ} \mathrm{C}$ at farm 3.
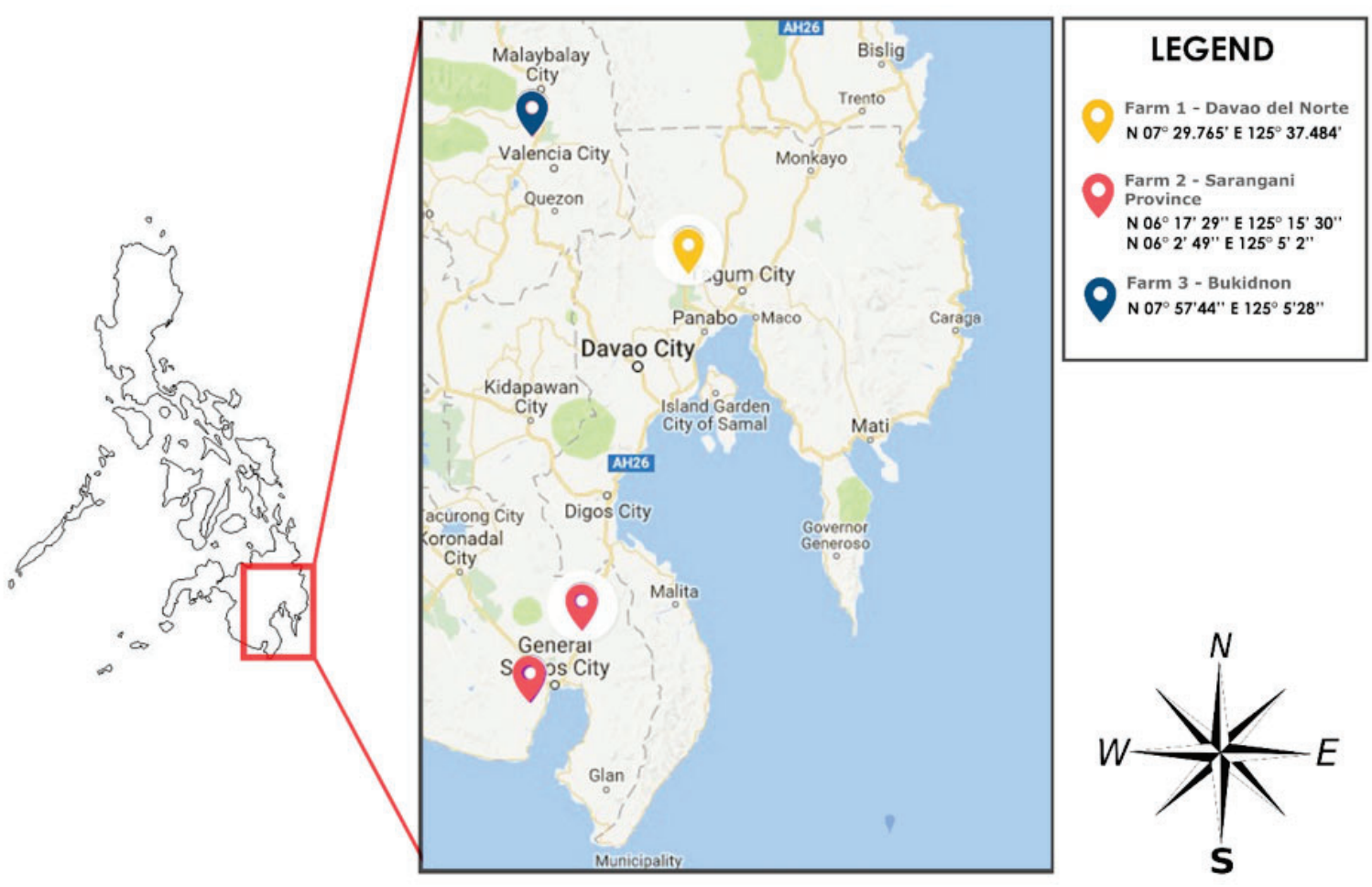

Figure 1. Map showing anaerobic soil disinfestation field trial sites in southern Philippines.

At each site we laid out gross and net experimental plots for ASD application. The size of the gross plots was $10 \times 10 \mathrm{~m}$ with a central net plot of $5 \times 5 \mathrm{~m}$ (Figure 2). The plot sites were dug out until $50 \mathrm{~cm}$ depth (Figure $2 \mathrm{~B}$ ) and Herbie 25 and Herbie 82 were applied as a mixture (Figure 2) at $3 \mathrm{~kg} \cdot \mathrm{m}^{-2} \mathrm{Herbie}^{\circ} 25$ and $4.5 \mathrm{~kg} \cdot \mathrm{m}^{-2}$ Herbie $^{\circ} 82$ for the net plots and $1.5 \mathrm{~kg} \cdot \mathrm{m}^{-2}$ Herbie $^{\circ} 25$ and $2.3 \mathrm{~kg} \cdot \mathrm{m}^{-2} \mathrm{Herbie}^{\circ} 82$ for the gross plots. Subsequently five layers of $10 \mathrm{~cm}$ soil were consecutively mixed with $20 \%$ of the Herbie mixture until the dug-out area was again filled-up. Soil layers and Herbie were manually (Farm 1 and 2) or mechanically mixed using a tractor machine (Kubota, Japan; Farm 3) (Figure 2). Net plots were completed first and then covered with an airtight plastic film (polyethylene-based plastic of 152.4 microns, farm 1, or 40 microns, farms 2 and 3). Then the gross plot was completed, and the entire test plot was covered with two layers of plastic (polyethylene-based plastic of 152.4 microns, 
farm 1) or 76.2 microns, farms 2 and 3; Figure 2). After eight weeks the plastic was removed and soil samples of approximately $1 \mathrm{~kg}$ were randomly collected at $50 \mathrm{~cm}$ and $100 \mathrm{~cm}$ depth in the net and gross plots. Subsequently, Cavendish cv. Williams was randomly planted in each net and gross plot as well as in adjacent untreated soil at one week after treatment and disease severity was recorded at weekly intervals.

In order to determine the effect of ASD we buried open containers (similar as the laboratory trials) with naturally infested soil and Herbie ${ }^{\circ}$ applications with the nylon mesh bags containing a known quantity of TR4 chlamydospores (Figure S1), at each trial site in the gross (four containers) and net plots (five containers) at a depth of $50 \mathrm{~cm}$ (Figure S1). The containers were collected from the field after the plastic was removed at the end of the ASD treatments and the meshes were collected for TR4 quantification in the laboratory.

\section{Assessment of viable TR4 chlamydospores}

To determine the efficacy of ASD we quantified the number of viable chlamydospores prior and post the treatments inside the nylon mesh bags by spiral plating method (Gilchrist et al., 1973) using a DW Scientific spiral plater (Smets Technology Alliance Group, The Netherlands). For each sample, approximately $10 \mathrm{~g}$ of collected soil was diluted in $95 \mathrm{ml} 0.1 \%$ sodium pyrophosphate (Sigma, USA) and mixed for $10 \mathrm{mins}$. Soil suspensions were subsequently diluted in $1 / 4$ Ringers solution (Honeywell Fluka, Germany), spread on Komada agar plates and incubated at $25^{\circ} \mathrm{C}$. After three days, the number of TR4 colonies were counted.

\section{DNA isolation and TR4 detection}

Naturally infested soils from the gross and net plots at each of the trial sites were collected at $-25,-50,-75$, and $-100 \mathrm{~cm}$ below surface prior and after the treatment. DNA extractions were conducted for each of the collected soils using the MoBio kit (MoBio laboratories, USA) that is compatible with the Kingfisher DNA extraction robot (KingFisher ${ }^{\mathrm{TM}}$ Flex Purification System, Thermo Fisher Scientific ${ }^{T M}$, USA) with minor modifications. A $0.25 \mathrm{~g}$ soil sample (four replicates each) was placed in the 96-well well plate provided with the kit and added with $754 \mu \mathrm{l}$ of bead solution:RNAse A solution and $60 \mu \mathrm{l}$ of lysis solution.

The plate was then placed in water bath at $70^{\circ} \mathrm{C}$ for $10 \mathrm{~min}$, bead beated for $20 \mathrm{~min}$ at speed 30 (Tissuelyser II, Qiagen, USA), and centrifuged at room temperature for $10 \mathrm{~min}$ at $4500 \mathrm{~g}$ (Thermo Fisher Scientific ${ }^{\mathrm{TM}}$, USA). The supernatant $(450 \mu \mathrm{l})$ was transferred to a cold plate containing $450 \mu \mathrm{l}$ of IRT solution and vortexed briefly. After $10 \mathrm{~min}$ incubation at $4^{\circ} \mathrm{C}$, the plate was centrifuged at room temperature for $10 \mathrm{~min}$ at $4500 \mathrm{~g}$ (Thermo Fisher Scientific, USA). Subsequently, approximately $675 \mu$ of the supernatant was placed in a new deep well plate provided with the kit and centrifuged again at the same aforementioned specifications. Finally, $450 \mu \mathrm{l}$ of the supernatant was transferred to a new $2 \mathrm{ml}$ KingFisher plate and processed following manufacturer's instruction. As a positive control for the extraction, Dutch sandy soil was spiked with TR4 chlamydospores (isolate Phil 2.6c; Ordoñez 
et al., 2015). Uninfested soil was used as negative control. Extracted DNA was analysed using the developed TaqMan probe-based real time PCR (Salacinas et al., 2019; see Chapter 3). As external control DNA, potato leaf roll virus (PLRV) plasmid DNA was added to each extraction tube prior to processing to compensate for extraction differences and qPCR inhibitory compounds in the samples.

\section{Data analysis}

The means of TR4 population densities were subjected to analysis of variance (ANOVA) on log-transformed data (log CFU +1 ) followed by REML variance analysis (Genstat 64-bit version 8.1, VSN International Ltd.). Contrast analyses were performed between containers and individual treatments and the experimental location.

A

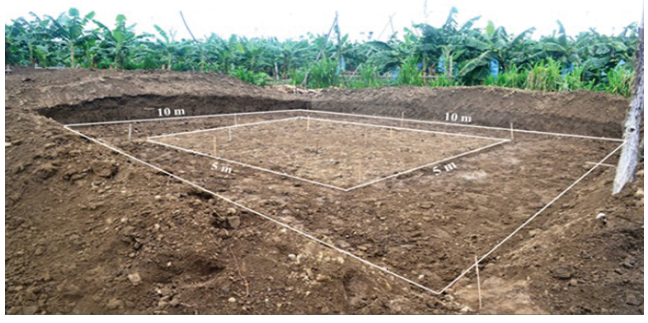

C

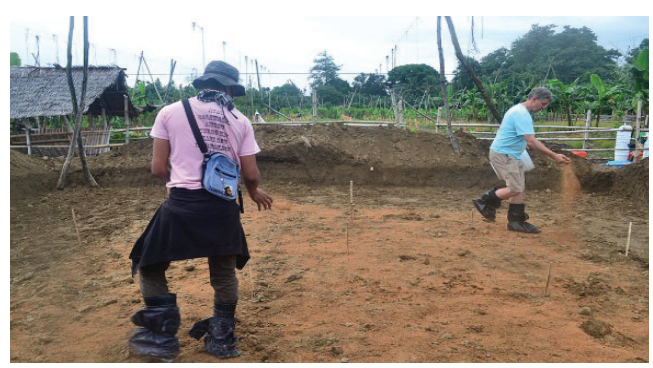

$E$

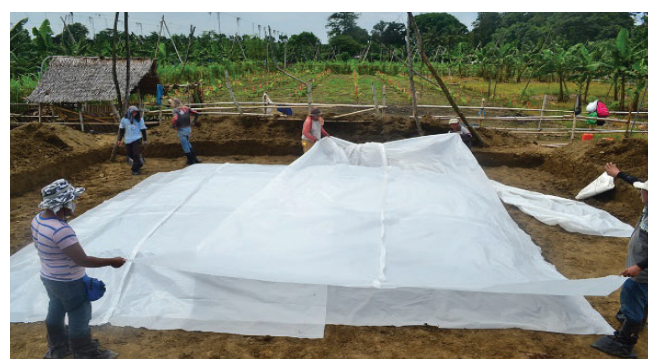

B

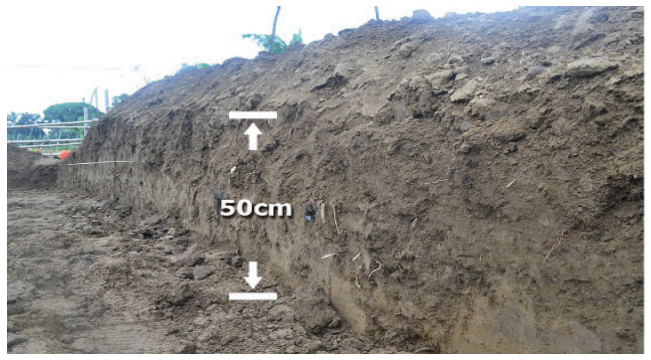

D

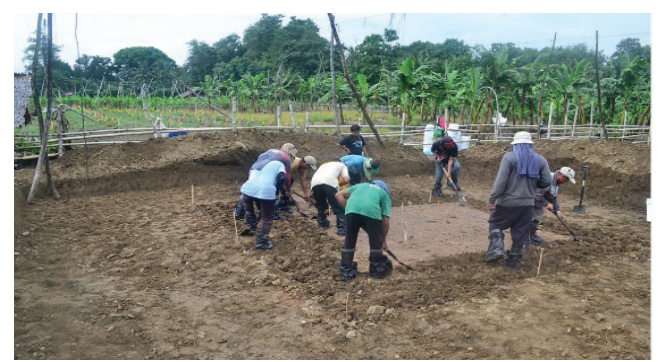

$\mathrm{F}$

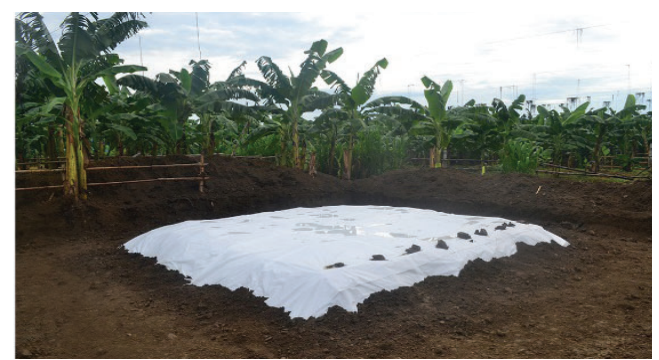

Figure 2. Anaerobic soil disinfestation field trial showing the gross and net plot (A). Soil at $50 \mathrm{~cm}$ depth below was dug out (B), applied with Herbie products $(C)$ either manually or mechanically mixed by spading (D), and completed by covering with airtight plastic films for eight weeks (E-F). 


\section{Results}

\section{ASD is effective against TR4 chlamydospores under airtight conditions}

To test the efficacy of ASD to TR4 chlamydospores, two laboratory experiments were performed. In the first experiment we determined the number of viable chlamydospores at weekly intervals during four weeks. In the absence of Herbie ${ }^{\circ}$, no significant reduction of viable chlamydospores was observed in open or closed containers. Similarly, Herbie ${ }^{\circ}$ application without closing the container did not significantly affect the number of viable chlamydospores. In the presence of Herbie ${ }^{\circ}$ and closure of the container, the population density of viable TR4 chlamydospores reduced significantly relative to all other treatments (Figure 3). This shows that ASD is effective against TR4 under airtight conditions. In the Philippine laboratory trial, the number of viable chlamydospores was determined from the recovered bags by spiral plating. The Herbie applications significantly reduced the TR4 chlamydospores inoculum levels for Herbie 25 and Herbie 82 individually as well as the mixed application compared with the control (Figure 4). However, the reduction in the laboratory trial in The Netherlands was much higher than in The Philippines.

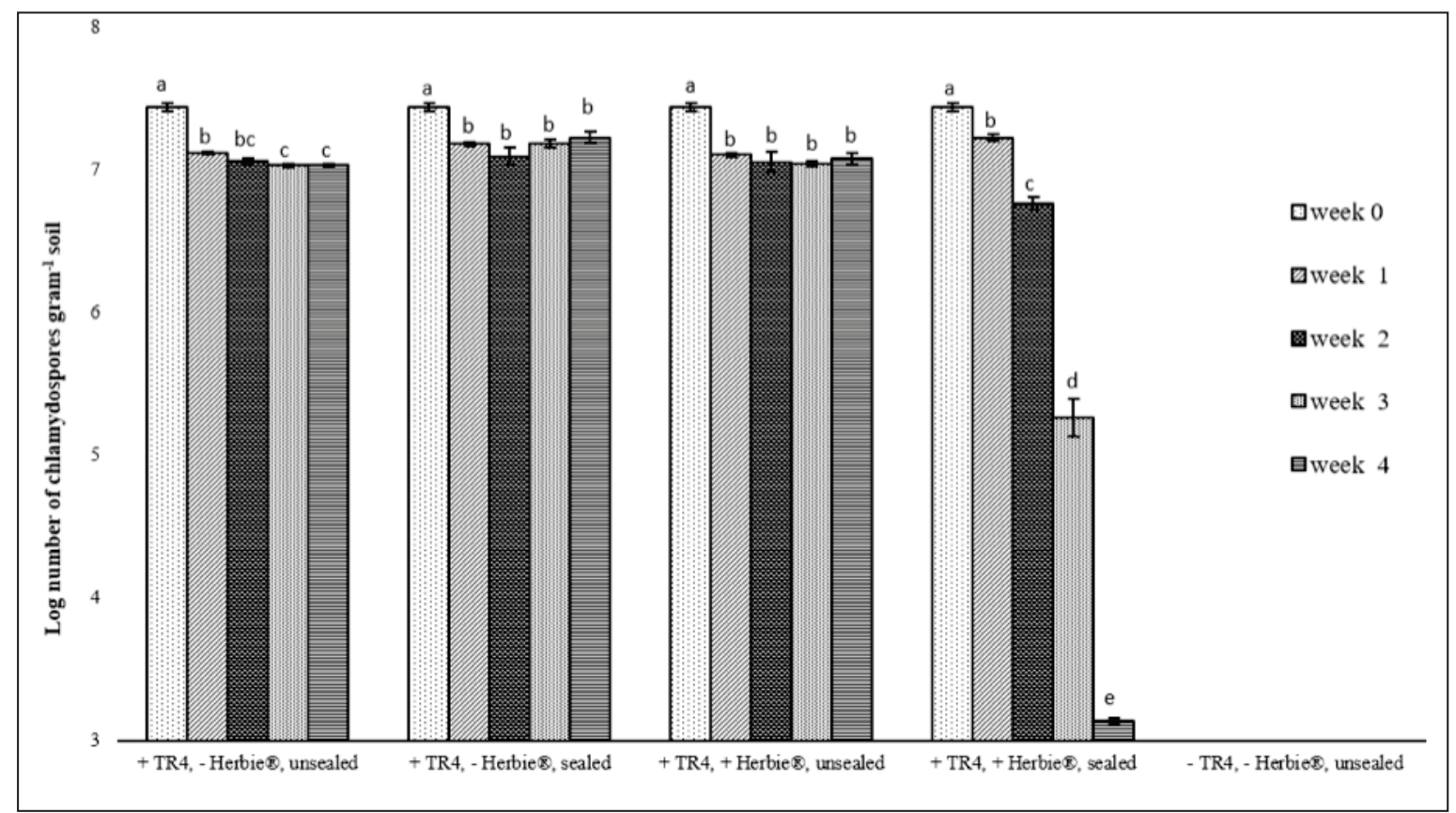

Figure 3. Survival rates of Fusarium odoratissimum, Tropical Race 4 (TR4), chlamydospores in the Dutch container experiment. Values were determined by spiral plating and presented as log transformed means. Error bars indicate the standard error. Different letters indicate significant differences between means with a confidence level of $95 \%$ (Statistica v. 12.0). 


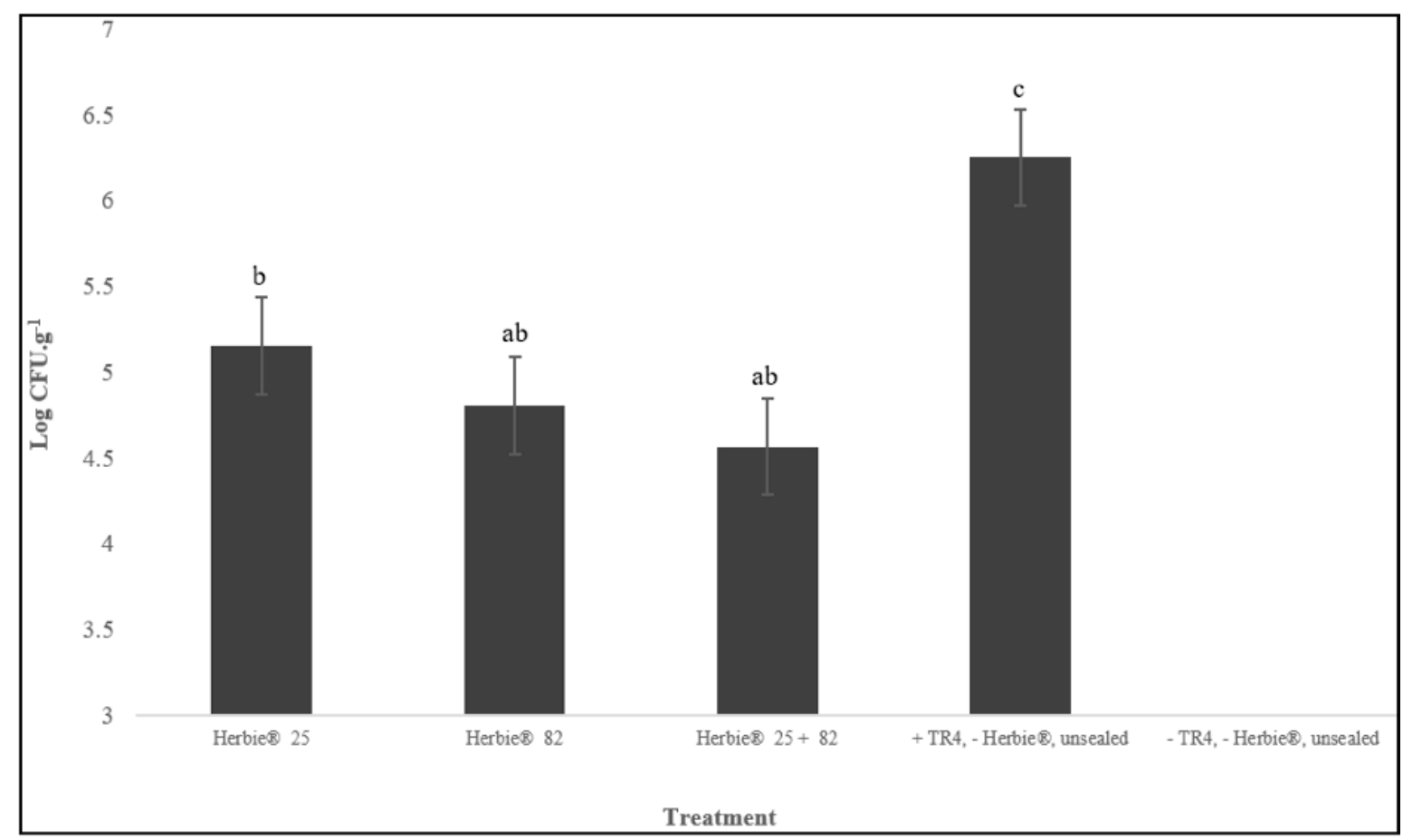

Figure 4. Effect of Herbie treatments on the survival of Fusarium odoratissimum, chlamydospores (log CFU.g soil $\left.{ }^{-1}\right)$. All containers, containing nylon mesh bags with TR4 chlamydospore, were tightly sealed and stored for eight weeks. Artificially inoculated soil (+TR4, - Herbie', unsealed) was used as positive control and autoclaved soil (- TR4, - Herbie ${ }^{\circ}$, unsealed) as negative control. Values are presented as means \pm standard error of means of log transformed numbers (error bars). Significantly different values (confidence level of 95\%) are presented as bars with different letters (Genstat 64-bit v8.1).

In the laboratory trials in The Netherlands we also monitored the production of toxic gases and volatile fatty acids during the execution of the experiment. The $\mathrm{O}_{2}$ concentration rapidly dropped for both treatments as a result of consumption by aerobic microbial activity (Runia et al., 2014) within one week after the closure, but declined slightly slower in the control (infested soil without Herbie ${ }^{\circ}$ ), potentially due to the lower starting levels of organic matter (Figure 5, Table S2). The production of $\mathrm{CO}_{2}$ mirrored to the decrease of oxygen and remained at around $140.10^{3} \mathrm{ppm}$ and $60.10^{3} \mathrm{ppm}$ with and without Herbie-amendment, respectively (Figure 5, Table S2). 
$\mathbf{O}_{2}$

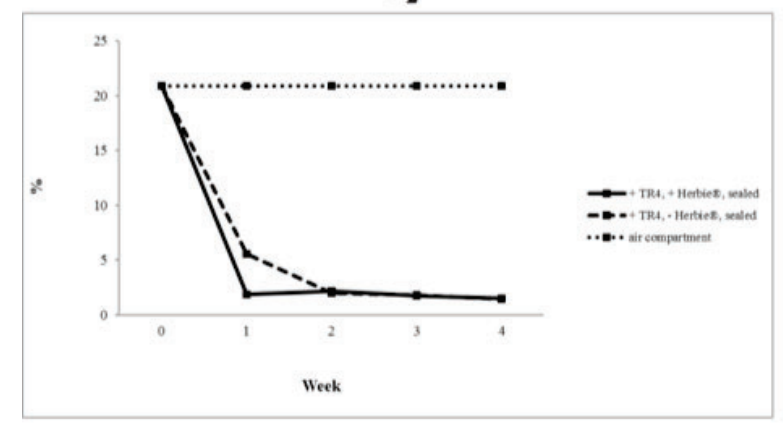

$\mathrm{N}_{2} \mathrm{O}$

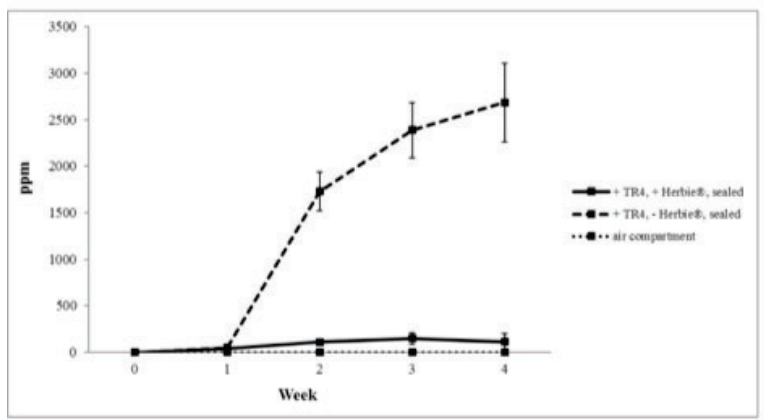

$\mathrm{CH}_{4}$

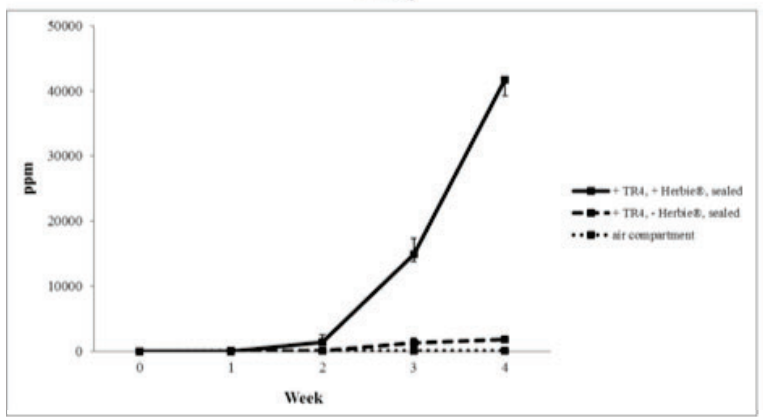

$\mathrm{CO}_{2}$

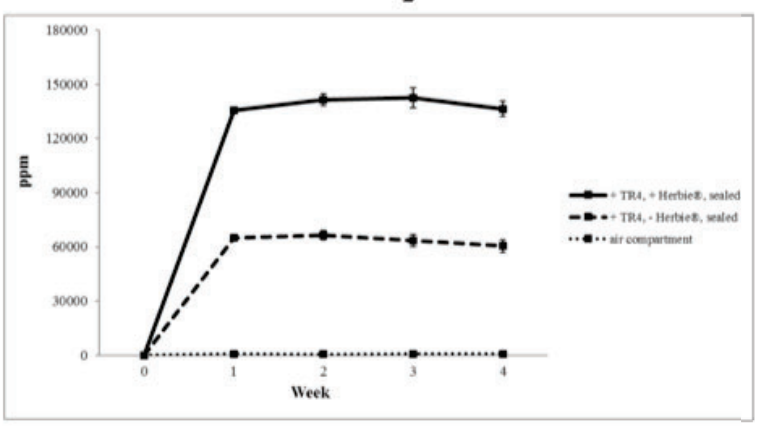

$\mathrm{NH}_{3}$

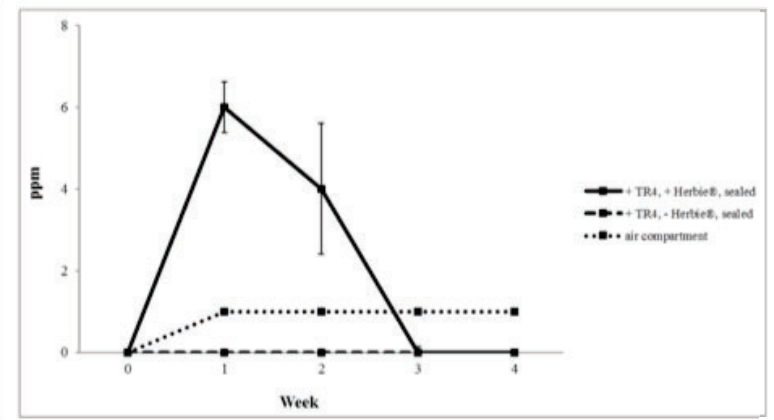

$\mathrm{H}_{2} \mathrm{~S}$

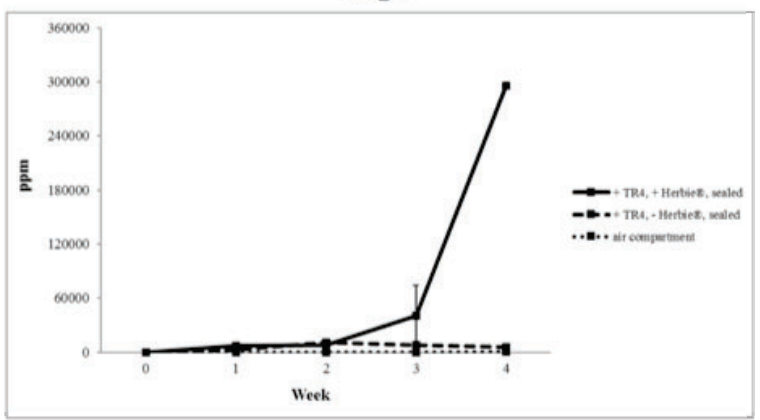

Figure 5. Gas concentrations as a function of time (week) during an anaerobic soil disinfestation experiment that lasted for four weeks at $24^{\circ} \mathrm{C}$ in airtight containers filled with soil with or without Herbie .

The production of nitrous $\mathrm{N}_{2} \mathrm{O}$ peaked at $2700 \mathrm{ppm}$ without Herbie ${ }^{\bullet}$ while only a maximum

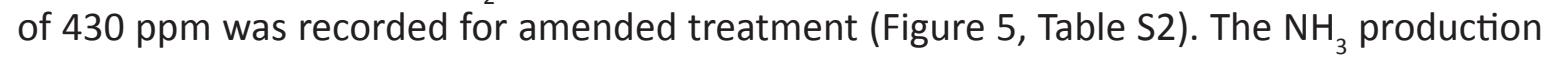
was only observed for the Herbie-amended treatment but levels reduced at week three beyond detection level (Figure 5, Table S2). The $\mathrm{CH}_{4}$ accumulated rapidly after two weeks in the amended treatment up to over $40.10^{3} \mathrm{ppm}$ after four weeks while a minor increase was observed in the non-amended treatment (Figure 5, Table S2). Similarly, $\mathrm{H}_{2} \mathrm{~S}$ levels increased in the amended treatment to maximum of $300.10^{3} \mathrm{ppm}$ (Figure 5, Table S2).

In the non-amended treatment, the volatile fatty acids acetic acid, proprionic acid, butyric acid and iso-butyric acid were hardly produced in time. In contrast, their amounts 
significantly increased when Herbie was applied (Figure 6, Table S3). Valeric and iso-valeric acid were generated with and without Herbie in the first two weeks. After this period, the production was sustained in the Herbie treatment but both levels reduced in the untreated containers (Figure 6).
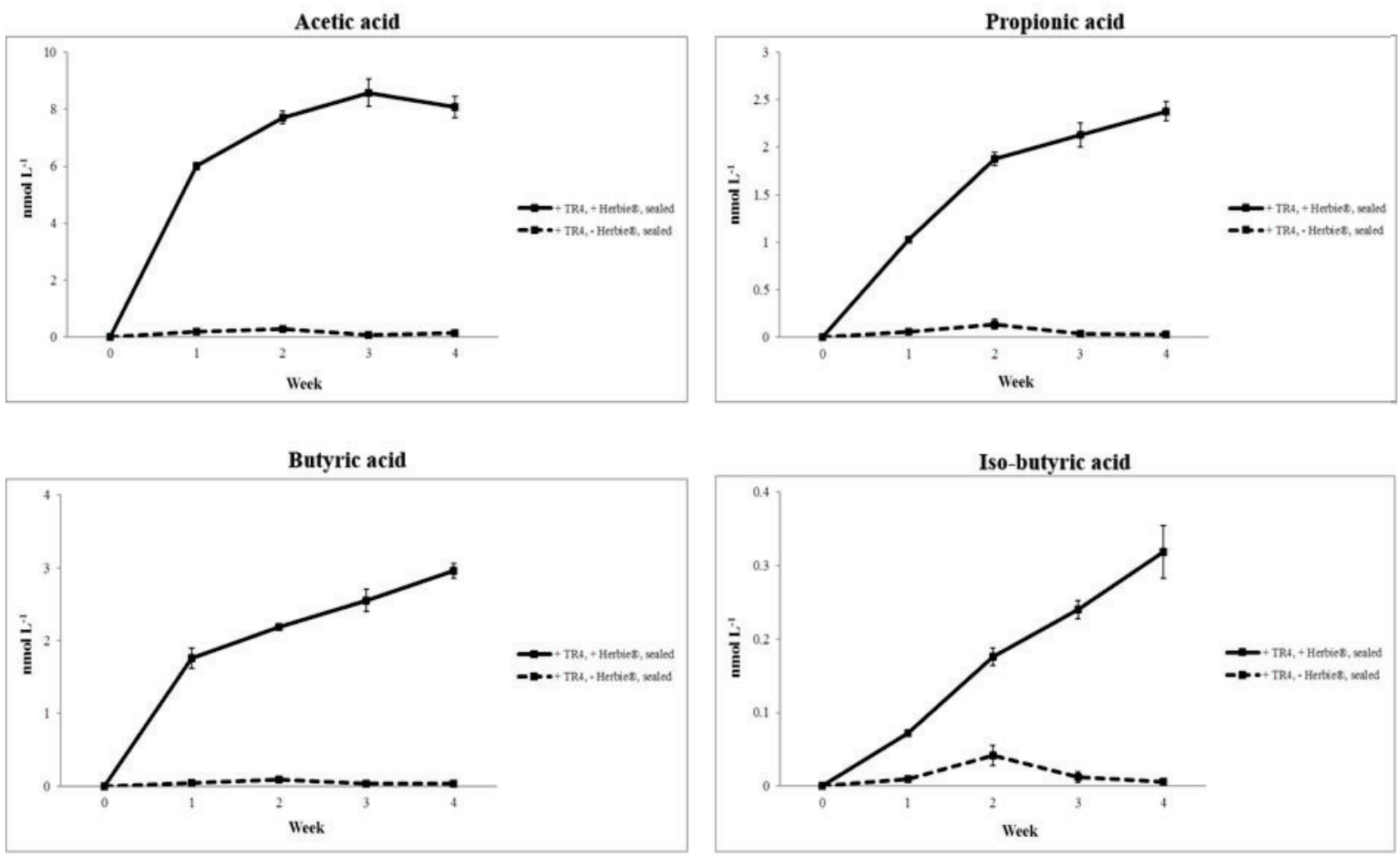

Valeric acid
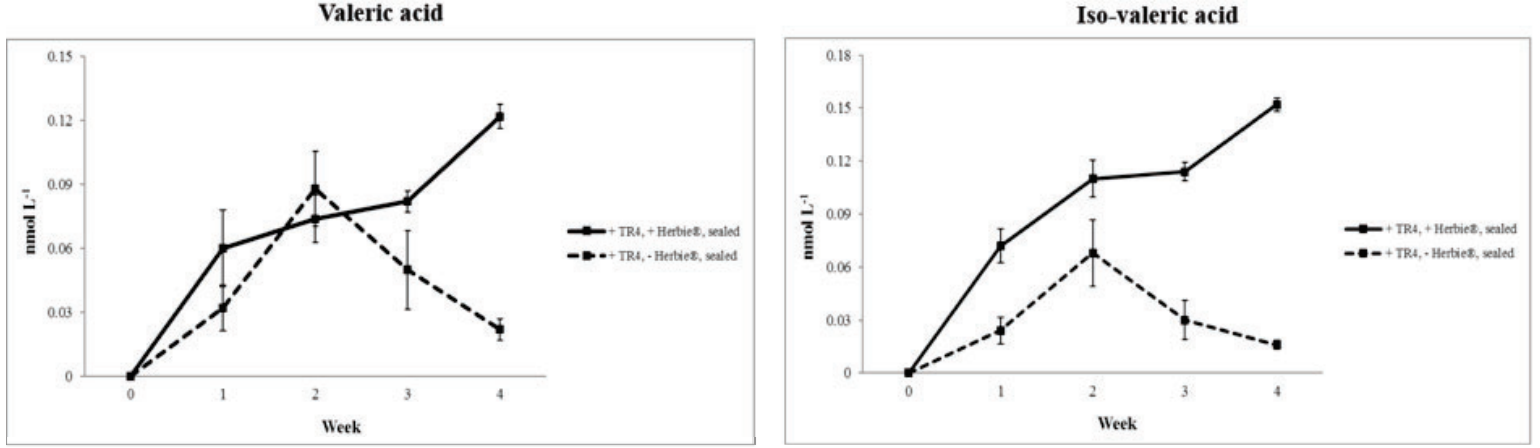

Figure 6. Weekly measurements of volatile fatty acids production as a function of time (week) during an anaerobic soil disinfestation experiment that lasted for four weeks at $24^{\circ} \mathrm{C}$ in airtight containers filled with soil with or without Herbie ${ }^{\circ}$.

After the initiation of the experiment with the closed containers we also monitored the $\mathrm{pH}$ over time. An increase of the $\mathrm{pH}$ was observed in the first week in the non-amended treatment that was higher than in the Herbie-amended treatment. Over time, the $\mathrm{pH}$ difference was sustained and on average, the $\mathrm{pH}$ in the amended treatment was about 0.7 units lower than the non-amended treatments (Figure 7). 


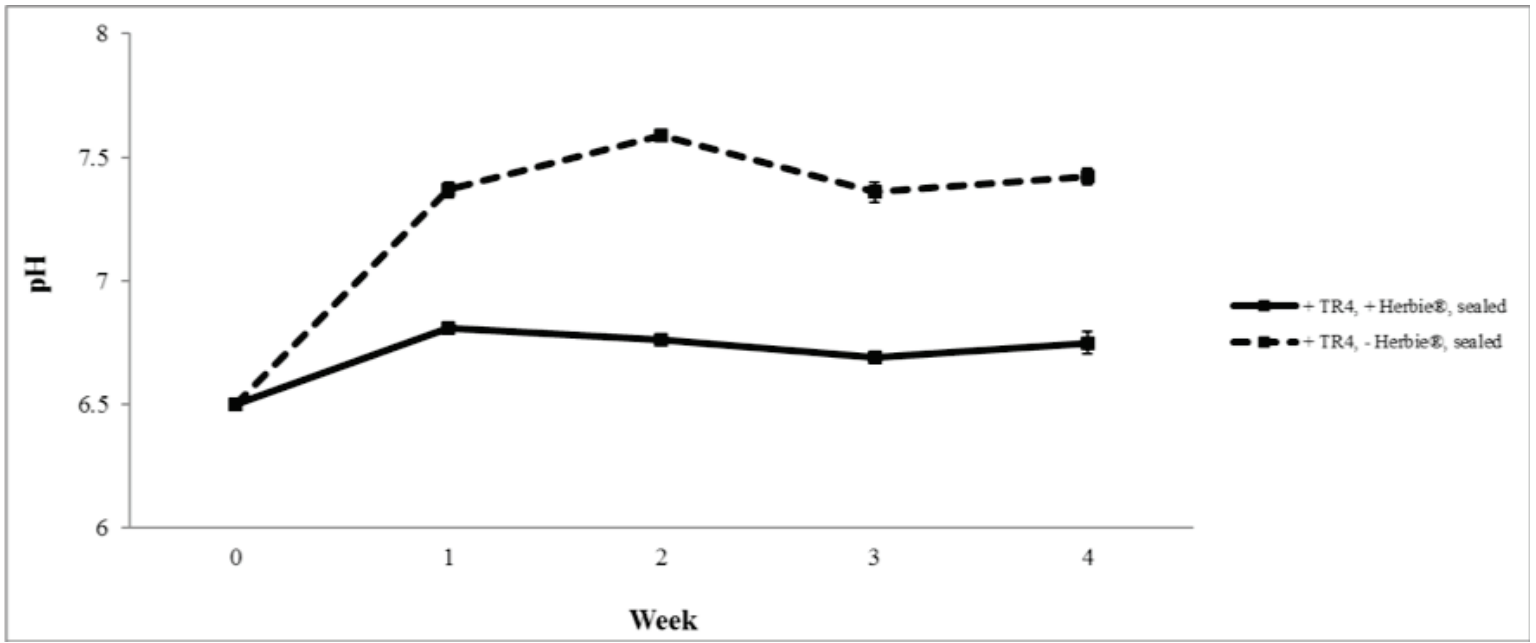

Figure 7. Soil acidity $(\mathrm{pH})$ as a function of time (week) during an anaerobic soil disinfestation experiment that lasted for four weeks at $24^{\circ} \mathrm{C}$ in airtight containers filled with soil with or without Herbie .

\section{ASD is effective in field trials}

To determine the efficacy of ASD for Panama disease management under field conditions we determined the survival of TR4 chlamydospores in buckets at three farms. In the control samples, no significant reduction of colony forming units (cfu's) was observed in the absence of Herbie ${ }^{\circ}$. The reduction in the net plots was over 100 -fold whereas in the gross plot a 20 fold reduction of cfu's was observed (Figure 8, Table 2).

Table 2. Anaerobic soil disinfestation (ASD) in the Philippines. Analysis of viable chlamydospores of Fusarium odoratissimum, Tropical Race 4 (TR4), after ASD under field conditions. Known quantities of chlamydospores in nylon mesh bags are placed in a container and submerged in the ASD treated soil. Binary values indicate the number of containers with no viable TR4 chlamydospores relative to the total number of containers used in the trial.

\begin{tabular}{llll}
\hline Treatment $^{\mathbf{b}}$ & \multicolumn{3}{c}{ Field location $^{\mathbf{a}}$} \\
& Farm 1 & Farm 2 & Farm 3 \\
\hline Herbie $^{\circ}$ 25 & $0 / 18$ & $9 / 18$ & $6 / 18$ \\
Herbie $^{\circ} 82$ & $3 / 18$ & $18 / 18$ & $9 / 18$ \\
Herbie $^{\circ} 25+$ Herbie $^{\circ} 82$ & $12 / 18$ & $12 / 18$ & $12 / 18$ \\
Herbie $^{\circ} 25+$ Herbie $^{\circ} 82$ gross & $3 / 24$ & $24 / 24$ & $3 / 24$ \\
Herbie $^{\circ} 25+$ Herbie $^{\circ} 82$ net & $9 / 30$ & $21 / 30$ & $12 / 30$ \\
Infested, Herbie non-amended, sealed $_{\text {Non-infested, Herbie non-amended, sealed }}$ & $0 / 18$ & $0 / 18$ & $0 / 18$ \\
\hline
\end{tabular}

${ }^{a}$ Binary score was a combination of the two plots to each trial site

${ }^{\mathrm{b}}$ Treatment both in laboratory and field 
We recovered viable chlamydospores from all trial sites, except from farm 2 in the gross plot as shown in Table 2. This was validated by TaqMan probe-based Real-Time qPCR and showed that all samples were positive in all soil layers, hence contained TR4 DNA (data not shown). This indicates that all chlamydospores at farm 2 were killed by ASD, and that the viable inoculum of TR4 was significantly reduced at farms 1 and 3.

We also determined the quantitative presence of TR4 in all gross and net plots outside the containers - thus not in the mesh bags but directly in the natural soils - by qPCR at two layers $(0-50 \mathrm{~cm}$ and $51-100 \mathrm{~cm})$, which confirmed that the ASD treatment reduced the TR4 inoculum load especially in the upper $50 \mathrm{~cm}$ soil layer (Table 3 ).

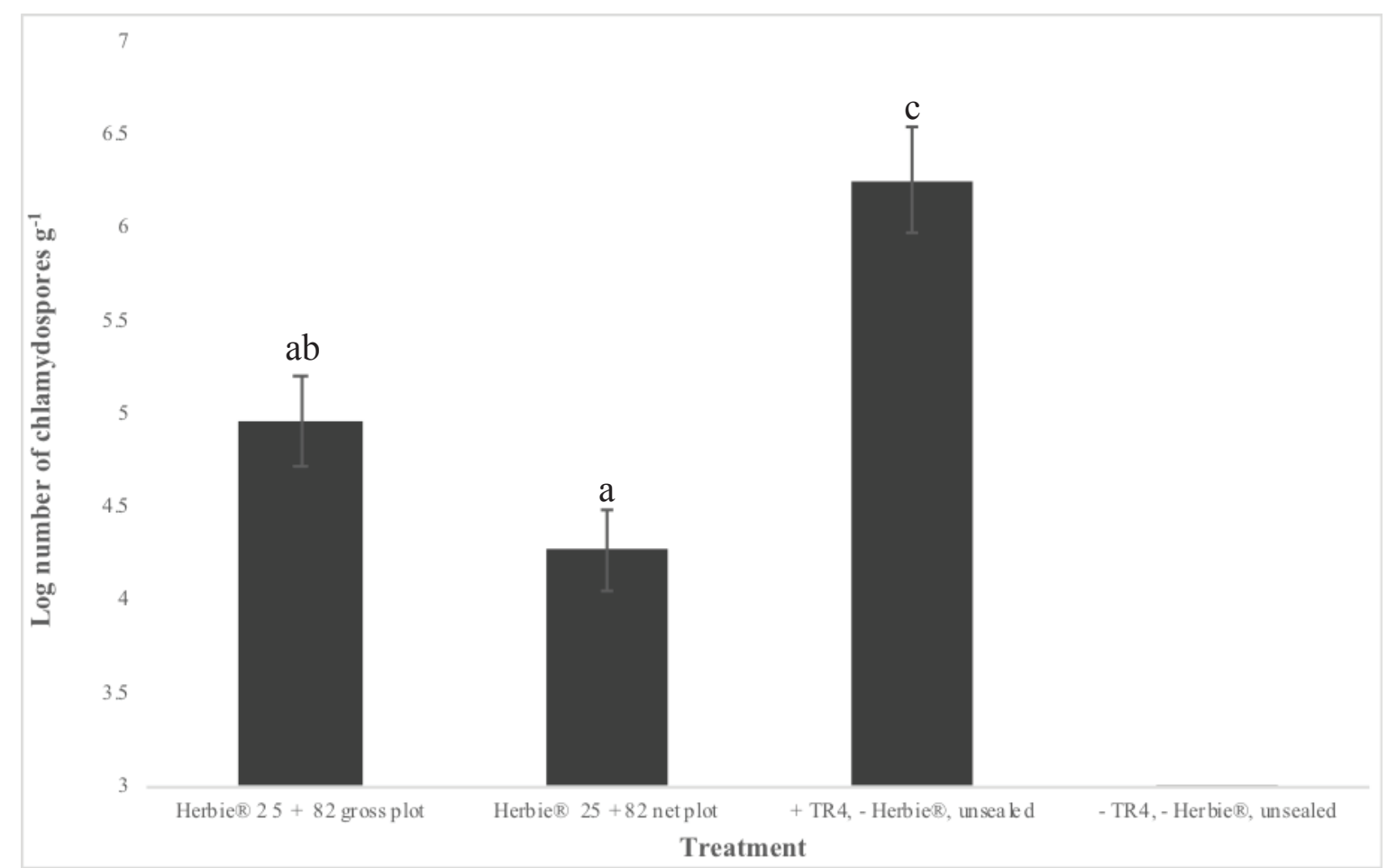

Figure 8. Anaerobic soil disinfestation (ASD) of Philippine soil naturally infested with Fusarium odoratissimum, Tropical Race 4 (TR4). Efficacies are presented as log number of chlamydospores per gram of soil after an eight weeks ASD treatment. The containers (no lid) with chlamydospores bags were submerged in naturally infested soils. Artificially inoculated soil was used as positive control (infested, no Herbie ${ }^{\circledR}$, sealed) and autoclaved soil (non-infested, no Herbie ${ }^{\circledR}$ and unsealed) as negative control. Values are presented as means \pm standard error (bars) of the means of log transformed numbers. Letters indicate significant differences at 95\% confidence level (Genstat 64-bit v8.1). 
Table 3. Analysis of the presence of Fusarium odoratissimum, Tropical Race 4, at various depths in naturally infested soils after anaerobic soil disinfestation for eight weeks with Herbie ${ }^{\circ}$ products utilizing a TaqMan probe-based Real-Time qPCR assay.

\begin{tabular}{|c|c|c|c|c|}
\hline \multirow[t]{2}{*}{ Plot location } & \multicolumn{2}{|c|}{ Net plot } & \multicolumn{2}{|c|}{ Gross plot } \\
\hline & $0-50 \mathrm{~cm}$ & $51-100 \mathrm{~cm}$ & $0-50 \mathrm{~cm}$ & $51-100 \mathrm{~cm}$ \\
\hline Farm 1 & Present & Absent & Present & Present \\
\hline Farm 2 & Present & Absent & Present & Present \\
\hline Farm 3 & Absent & Present & Absent & Absent \\
\hline
\end{tabular}

\section{ASD reduces Panama disease incidence in treated plots}

All gross and net plots were replanted with Cavendish cv. Williams (highly susceptible to TR4) to investigate the efficacy of ASD by determining the recurrence of the disease over time. Every week the plants were visually inspected for external symptoms for one cropping cycle. At the end of the first harvesting cycle, none of the plants had developed Panama disease in the net plots of farms 2 and 3, but three plants were affected in farm 1 (Figure 9; Figure S3). These plants were positioned in the corner of the plot close to the gross plot and among those that are most vulnerable for infection from adjacent sides (Figure S4). The remnants, together with its sucker were immediately removed to avoid inoculum production. In the gross plot, $17 \%$ and $30 \%$ disease incidences were recorded in farm 1 and 2, respectively, but nothing in farm 3 (Figure 9). Although the controls were planted four months later than the treated plots, control plants just outside the perimeters of the plot rapidly manifested symptoms from the third month after planting and onwards.

In summary, collectively these results show that ASD significantly reduces TR4 inoculum in heavily infested soils and reduces Panama disease recurrence in planted Cavendish bananas. 


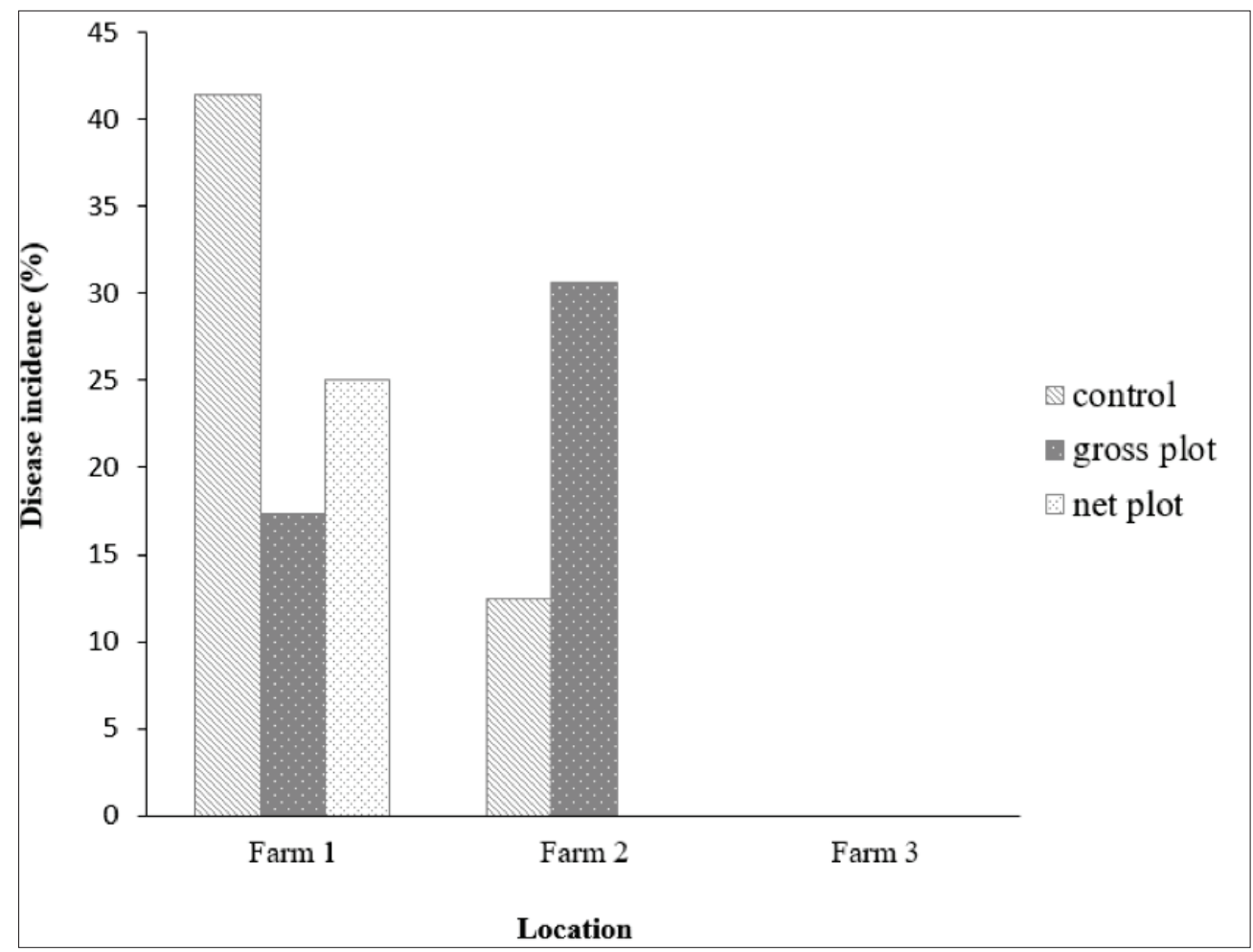

Figure 9. Recurrence of Panama disease in pilot plots that underwent an anaerobic soil disinfestation (ASD) treatment of eight weeks at three farms in Mindanao, Philippines. After the ASD treatment, each plot was replanted with Cavendish "Williams" and recurrence of disease was monitored for one cropping cycle.

\section{Discussion}

Pests and pathogens affect plants from moderate symptoms to devastations leading to the abandoning of areas planted to food crops (Strange and Scott, 2005). With the increasing impact of these destructive plant diseases, the current insufficiency of food supply is growing (Fisher et al., 2012; Bebber et al., 2013). In order to reduce these crop losses, it is indispensable to look for remedies either biological, chemical or integrative disease management strategies. Anaerobic soil disinfestation is a potentially interesting management option for Panama disease in banana, particularly since it has been deployed to control a number of other important soil-borne disease in various crops (Butler et al., 2012a; Butler et al., 2012b; McCarty et al., 2012; Shennan et al., 2014 ). The current dissemination of TR4 and the limited management options for this disease urged us to explore ASD for Panama disease management in banana. However, we preferred working with defined and commercially available products instead of undefined organic products or wastes. Herbie products were successfully applied for ASD under greenhouse and field conditions (http://thatchtec.nl/en/products/soil-resetting/), hence we explored using these products in banana, particularly since it works in the deeper layers of the soil as opposed to other practices commonly applied in the Philippines such as rice hull and wood burning 
(Salacinas et al., 2019). The baseline for ASD was determined in laboratory experiments under controlled condition in container assays. We monitored the rapid decline of oxygen and surveyed the production of various other gases that collectively reduced TR4 viability to $0.01 \%$ of the original high dose after a four weeks ASD treatment. Oxygen was depleted up to $1.5 \%$ after four weeks in the container assay. This level is somewhat higher than other studies wherein oxygen dropped to $<1.3 \%$ and $0.5 \%$ conducted at $20^{\circ} \mathrm{C}$ and $16^{\circ} \mathrm{C}$, respectively (Runia et al., 2014), which might be due to the higher temperatures $\left(24^{\circ} \mathrm{C}\right)$, permitting limited but somewhat higher oxygen flow from the compartment to the container. Indeed, spiral plating method revealed that sealing containers without Herbie-amendment did not translate to significant reduction of TR4 chlamydospores viability after four weeks. It is likely that a multitude of mechanisms are contributing synergistically to chlamydospores decline. These mechanisms include the accumulation of toxic gases and production of volatile fatty acids such as $\mathrm{CH}_{4}, \mathrm{H}_{2} \mathrm{~S}$ and $\mathrm{CO}_{2}$ as well as acetic acid, propionic acid, butyric acid and slight valeric acid levels along with ammonia, which quickly declined after the first week, likely due to volatilization as an effect of high temperature.

Performing a comparable experiment using Philippine amended soil also significantly reduced the viability of TR4 chlamydospores, but not as low as the laboratory trial in The Netherlands. This can be explained by the fact that we supplemented each container in the Dutch trials directly with Herbie products, whereas their concentration was much lower in the Philippines trials where we used the infested and field amended soil without any additional Herbie supplements directly in the container. We also used different container types that might have variable oxygen permeability. Under field conditions, ASD resulted in significant 20x to 100x reductions of inoculum levels compared to the control in the gross and net plots, respectively. We eventually demonstrated this reduced inoculum load by a significantly lower recurrence of Panama disease once the treated plots were replanted with susceptible Cavendish banana. The disease recurred at variable intervals, but the first infected plants were only observed after 14 and 5.5 months after planting in the net and gross plot, respectively. This is a significant delay relative to the untreated plot as early as three months after planting. Compared to the laboratory assays, generating and maintaining anaerobic soil conditions in the field was difficult. Especially during strong winds and stray animals passing the plots and birds can also rupture the plastic cover resulting to leaks that nullify the anaerobic conditions. We tried to minimize these effects situating a net plot in the centre of a gross plot (Messiha et al., 2007). The applied plastic with the required oxygen transmission specifications was employed in all test plots, but not in farm 1 as the provided plastic unintentionally disappeared from the warehouse after custom declaration. This might be the reason for the recurrence of Panama disease already three months after planting and eventually even in the net plot, which strongly contradicted with the results at the other locations.

In the field, we did not monitor the oxygen decline, but previous studies showed that the oxygen content of the soil covered with plastic dropped quickly under $1 \%$ after a few hours and were maintained for several weeks (Termorshuizen et al., 2000). A significant 
reduction of viable TR4 chlamydospores in ASD treatment can be correlated with toxic gases and volatile fatty acids, as was observed in the laboratory assays. Acetic acid is effectively used for disinfection of several pathogens (Levine and Fellers, 1940). Butyric acid proved to be effective in eliminating plant parasitic nematodes such as Meloidogyne hapla and $M$. incognita (Browning et al., 2006). In a study conducted by Runia et al. (2014), the survival of potato cyst nematodes was strongly correlated with the accumulation of these volatile fatty acids. Momma et al. (2006) demonstrated that acetic and butyric acid suppressed the survival of $F$. oxysporum f.sp. lycopersici (Fol) and Ralstonia solanacearum in a glass bottle experiment with artificially inoculated soil. Later, Momma (2008) showed that chlamydospores germinated in the early (aerobic) stage of the treatment apparently due to the stimuli from the decomposing organic source and were subsequently killed by fatty acids production. Similarly, Okazaki and Nose (1986) revealed that acetic and butyric acid play a significant role in eradicating $F$. oxysporum f.sp. raphani chlamydospores. Huang et al. (2015) demonstrated that the incorporation of $2 \%$ maize straw in combination with flooding resulted to the production of acetic acid, butyric acid, isovaleric acid and propionic acid leading to the reduction of inoculum of Panama disease inducing Fusarium spp. in soil in a pot assay and also affected the population of $R$. solanacearum and $R$. solani. The consistency of such results in additional trials and definitely for the implementation under field conditions is, however, questionable. Maize straw and most other applied biological amendments are variable in quality and composition, which hampers upscaling to an eradication method. Therefore, we have chosen to use commercialized products with consistent quality and composition. This facilitates upscaling from the current pilot to semi-commercial trials and after optimization to an applicable method for farm rehabilitation from TR4 infestation.

Another advantage of ASD is the gradual microbial recolonization by a range of aerobic organisms. This process can be influenced by inoculating beneficial or competitive microorganisms (Messiha, 2007). The facultative and obligate anaerobic fungal species that survive ASD might take part in the suppression of TR4 in the soil, similar to observations in experiments with Fol (Momma et al., 2005). Furthermore, the elimination of Fol was considered to correlate with the increase of bacterial communities in the soil after ASD (Momma, 2015). Mowlick et al. $(2013,2014)$ revealed that Bacillus spp. and Clostridia spp. dominated the soil microbial community post ASD treatment, the latter being known to be acid producers (acetic acid, propionic acid and butyric acid), which may contribute to the reducing effect (Momma, 2008). Efficient ASD treatment using rice bran and molasses resulted in the increase of bacterial densities from the phylum Bacteroidetes that was considered to antagonize inhabitant phytopathogenic microbial agents (Mazzola et al., 2016). Next generation sequencing of bacterial $16 S$ rRNA genes from soil treated with ASD using rice bran showed dramatic changes in bacterial community constituents, with the predominant genera Clostridiales, Acidobacteria and Burkholderia compared to the nontreated soils (Strauss and Kluepfel, 2015).

Organic matter plays an essential role in stimulating the biological activity which is important for the decay of Herbie (Runia et al., 2014). The soil we used in the Dutch laboratory trial 
had the highest organic matter content (4.3\%) and, indeed, we observed a sharp decline of viable TR4 inoculum to $0.01 \%$ in four weeks. Hence, the variable soil types may also have contributed to experimental flux in the field trials. The soil in farm 3 had the highest amount of organic matter (3.5\%, compared to $1.4 \%$ in farm $1,1.9 \%$ in farm $2-\mathrm{A}$ ) and $0.6 \%$ in farm 2-B), which may have contributed to significantly reduced recurrence of Panama disease after one cropping cycle.

In conclusion, the management of soil borne pathogens is a complicated process once traditional methods such as inundation and disinfection are abandoned or not anymore allowed. Reduction of pathogens in the top soil is usually not a major problem (Gurtler, 2017), but the efficacy of any method in the deeper layers of the soil is problematic, as recently shown by Salacinas et al. (2019). They demonstrated that viable spores of TR4 reside at depths of $100 \mathrm{~cm}$, and that presumed eradicative rice hull burning only increases the soil temperature to $\leq 40^{\circ} \mathrm{C}$ at $40 \mathrm{~cm}$, but beyond that depth, it has no effect. Also, this procedure only reduces inoculum of the infected plant area excluding the adjacent area that also carries pathogen inoculum. Hence, one has to consider the cost benefit ratio of these treatments. ASD has a much higher overall effect and penetrates deeper in the soil as demonstrated by the current data. After establishing a base-line efficacy under laboratory conditions, we subsequently piloted ASD in trial sites that are among the heaviest infested sites in Mindanao. Hence, our data are very encouraging, particularly since the recurrence of Panama disease was significantly delayed, up to over 400 days after replanting, while the controls developed Panama disease symptoms after 90 days, despite the fact that they were planted three months later.

Clearly, we acknowledge that our field data comprise a set of pilot experiment that require fine-tuning at a larger scale, which is currently ongoing and includes mechanization and diversifying plastic resources as well as Herbie concentrations. Developing reliable and efficacious eradication methods for the control of Panama disease is a multi-year and multi-site effort, but we demonstrate promising results that may contribute to short-term management options to slow down the disease and enable continued banana production. Moreover, ASD is scalable and hence can be applied at the various cropping methods from small-holder plots to large scale industrial production. This was shown for strawberry cropping in California (Muramoto et al., 2014; Shennan et al., 2011) as well as for the production of melons, tomatoes and cut flowers in Japan (Momma et al., 2013) and for strawberries, asparagus and tree nurseries in The Netherlands (Shennan et al., 2014). Taken together, ASD is a potential sustainable non-chemical management strategy to reduce Fusarium spp. in soil that after optimization could be considered as a rehabilitation procedure to restore banana production in Panama disease affected farms. 


\section{Acknowledgement}

This work was funded by the Wageningen University Interdisciplinary Research and Education Fund (INREF) (www.fusariumwilt.org). Banana research at WUR is supported by the Dutch Dioraphte Foundation endowed chair in Tropical Phytopathology of GHJK at the WUR-Laboratory of Phytopathology. We acknowledged the technical support of Thatchtec B.V., The Netherlands (www.thatchtec.nl) and are grateful to Odette Mendes and Mirjam Schilder, Wageningen Plant Research, for their assistance in the laboratory experiment. The collaborating companies in the Philippines; Tadeco Inc., Nader Ebrahim s/o Hassan Inc., and Unifrutti Tropical Philippines Inc. are wholeheartedly acknowledged for enabling, maintaining and monitoring the field trials. 


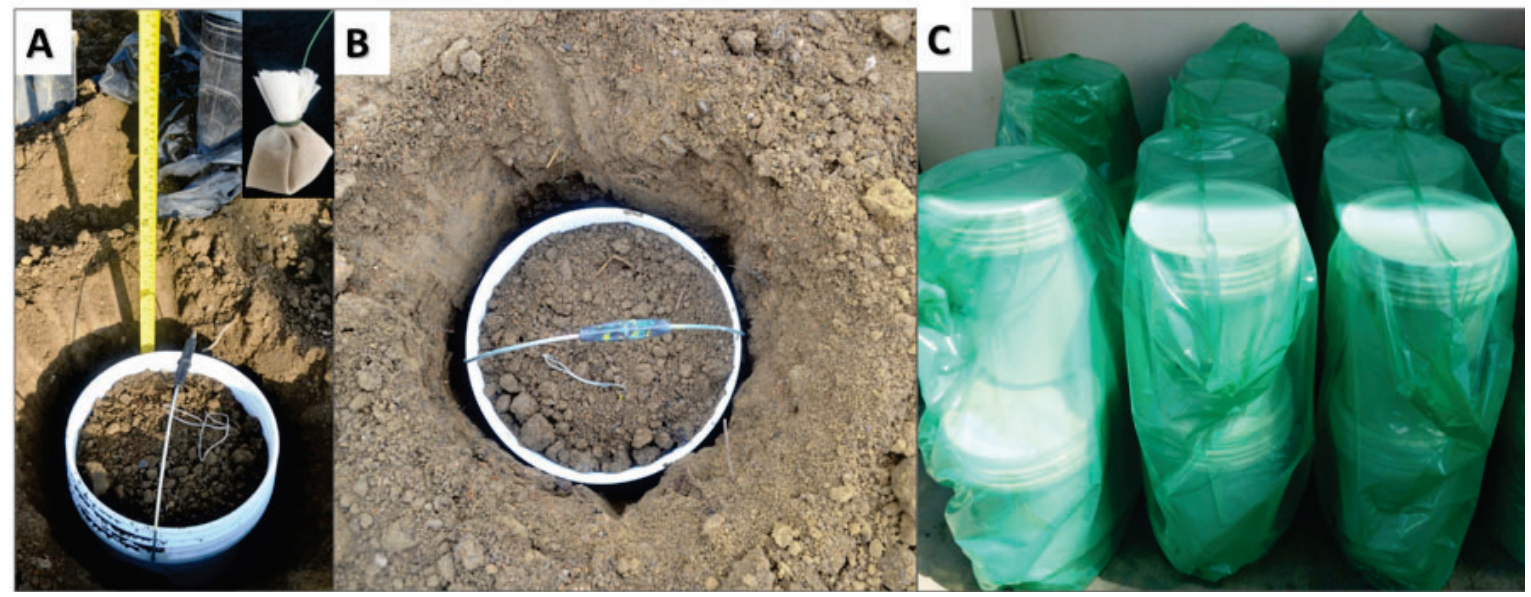

Figure S1. Containers with soil naturally infested with Fusarium odoratissimum, Tropical Race 4 (TR4), were supplemented with nylon mesh bags containing known volumes of TR4 chlamydospores (A) and were placed at $50 \mathrm{~cm}$ depth (B) in net and gross test plots that underwent anaerobic soil disinfestation at three farms in Mindanao, Philippines. Sealed containers with the same naturally infested soil were set aside in a compartment for eight weeks (C).
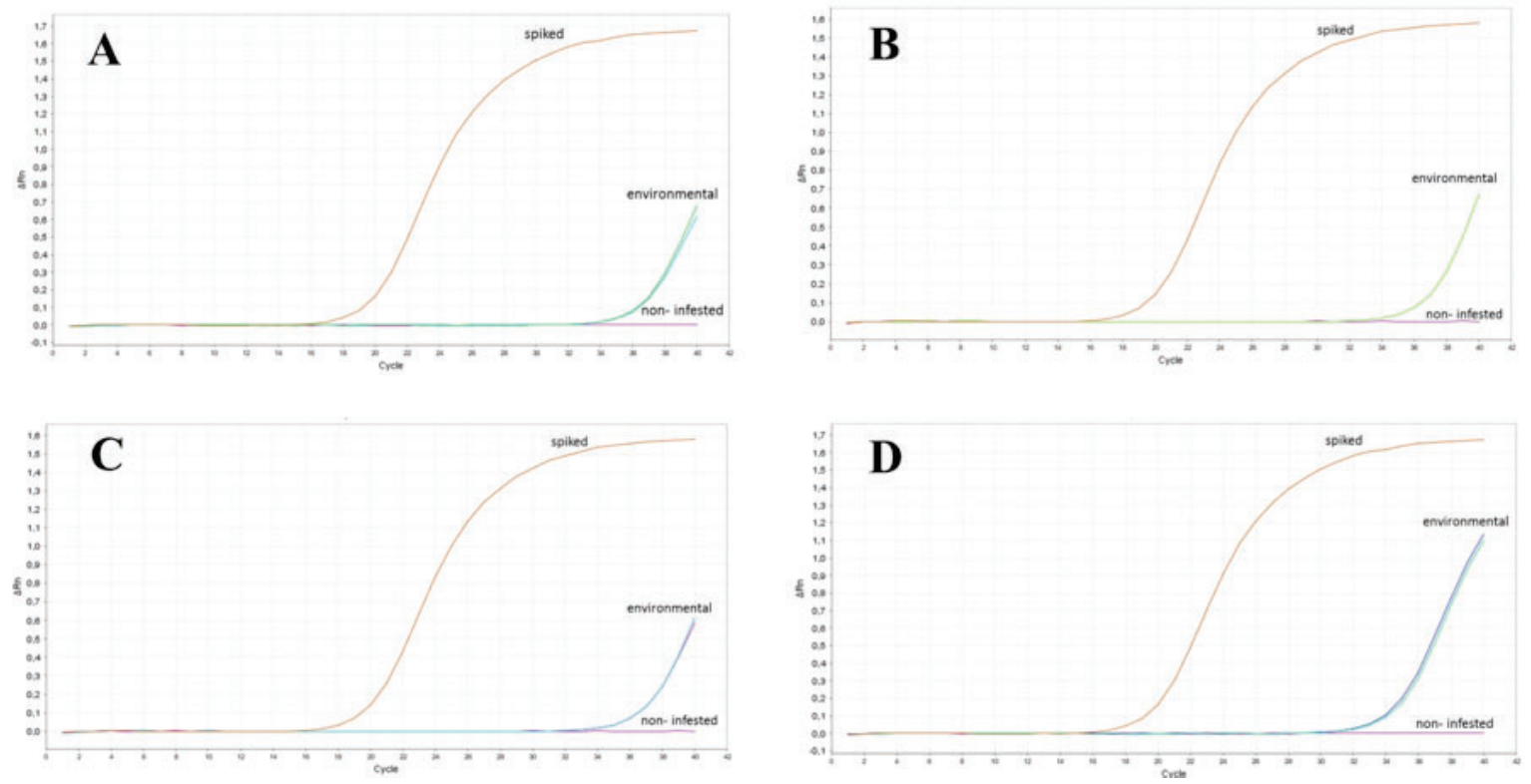

Figure S2. Determining the concentration of Fusarium odoratissimum, Tropical Race 4 (TR4), in naturally infested soils at various sites in Mindanao, Philippines. TaqMan probe-based Real-Time qPCR assays were conducted on samples collected at 50 and $100 \mathrm{~cm}$ below ground level of Farm 1 (A) Farm 2a (B) Farm $2 \mathrm{~b}(\mathrm{C})$ and Farm 3 (D). Control samples were Dutch sandy soils spiked with TR4 chlamydospores of $F$. odoratissimum isolate Phil 2.6c, prepared at Wageningen University and Research and included in nylon mesh bags in the container experiments. As extraction control we used the same non-infested Dutch sandy soil, which was autoclaved twice. 

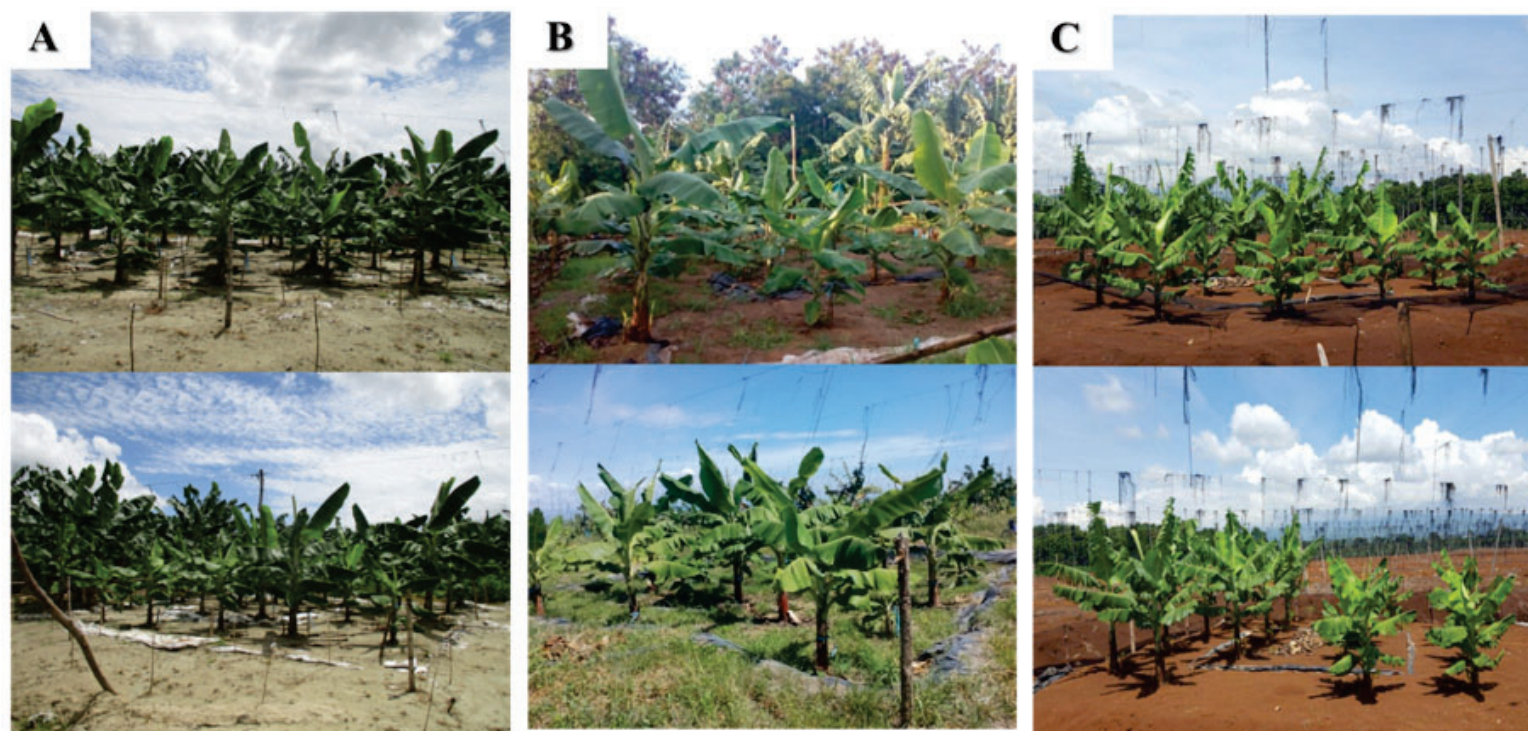

Figure S3. Replanted (Cavendish cv. Williams) pilot experimental plots at three sites in Mindanao that underwent an anaerobic soil disinfestation (ASD) treatment of eight weeks. Pictures of each replicate (upper and lower panels) were taken three months after planting at farm 1 (A), farm 2 (B) and farm 3 (C).
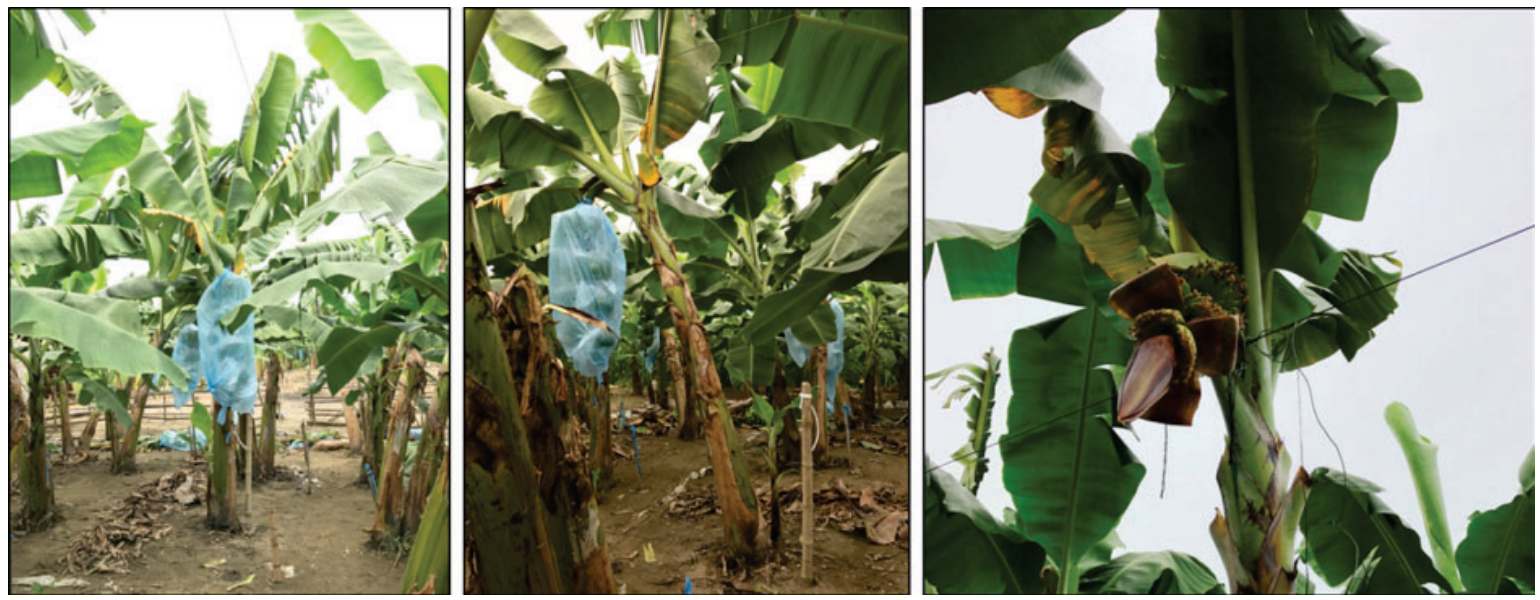

Figure S4. Recurrence of Panama disease symptoms after anaerobic soil disinfestation (ASD). Photographs show initial chlorosis of the leaf margins of the older leaves of Cavendish cv. Williams plants in one of the net plots at farm 1 in Mindanao, Philippines, which underwent an eight weeks ASD treatment.

Table S1. Physical and chemical characteristics of soils at different field trial sites in Mindanao, Philippines.

\begin{tabular}{lllll}
\hline Soil property & Farm 1 & Farm 2A & Farm 2B & Farm 3 \\
\hline soil type & clay loam & heavy clay & sandy loam & clay \\
pH & 6.7 & 7.3 & 7.5 & 6.6 \\
\% organic matter & 1.4 & 1.9 & 0.6 & 3.5 \\
\hline
\end{tabular}


Table S2. Gases produced as a function of time during an anaerobic soil disinfection laboratory experiment in the Netherlands for four weeks at $24^{\circ} \mathrm{C}$. Containers were filled with soil amended or non-amended with Herbie ${ }^{\bullet}$.

\begin{tabular}{|c|c|c|c|}
\hline \multirow[b]{2}{*}{ Gas } & \multicolumn{3}{|c|}{ Treatment $^{a}$} \\
\hline & + TR4, + Herbie ${ }^{\ominus}$, sealed & + TR4, - Herbie ${ }^{\bullet}$, sealed & Air compartment \\
\hline \multicolumn{4}{|l|}{$\mathrm{O}_{2}(\%)$} \\
\hline 0 week & 20.90 & 20.90 & 20.90 \\
\hline 1 week & 1.89 & 5.55 & 20.90 \\
\hline 2 week & 2.15 & 1.96 & 20.90 \\
\hline 3 week & 1.72 & 1.77 & 20.90 \\
\hline 4 week & 1.48 & 1.44 & 20.90 \\
\hline \multicolumn{4}{|l|}{$\mathrm{CO}_{2}(\mathrm{ppm})$} \\
\hline 1 week & 135475 & 64980 & 600 \\
\hline 2 week & 141500 & 66477 & 576 \\
\hline 3 week & 142700 & 63570 & 645 \\
\hline 4 week & 136500 & 60430 & 598 \\
\hline \multicolumn{4}{|l|}{$\mathrm{N}_{2} \mathrm{O}(\mathrm{ppm})$} \\
\hline 1 week & 42.88 & 50.63 & 0.00 \\
\hline 2 week & 110.18 & 1728.27 & 0.00 \\
\hline 3 week & 148.31 & 2388.90 & 0.00 \\
\hline 4 week & 115.31 & 2685.40 & 0.00 \\
\hline \multicolumn{4}{|l|}{$\mathrm{NH}_{3}(\mathrm{ppm})$} \\
\hline 1 week & 6.00 & 0.00 & 1.00 \\
\hline 2 week & 4.00 & 0.00 & 1.00 \\
\hline 3 week & 0.00 & 0.00 & 1.00 \\
\hline 4 week & 0.00 & 0.00 & 1.00 \\
\hline \multicolumn{4}{|l|}{$\mathrm{CH}_{\text {(ppm) }}$} \\
\hline 1 week & 0.00 & 0.00 & 21.00 \\
\hline 2 week & 1353 & 66 & 25.00 \\
\hline 3 week & 14929 & 1317 & 24.00 \\
\hline 4 week & 41660 & 1833 & 24.00 \\
\hline \multicolumn{4}{|l|}{$\mathrm{H}_{2} \mathrm{~S}(\mathrm{ppm})$} \\
\hline 1 week & 7288 & 2660 & 0.00 \\
\hline 2 week & 8081 & 10565 & 22 \\
\hline 3 week & 40070 & 7599 & 0.00 \\
\hline 4 week & 296000 & 5871 & 171 \\
\hline
\end{tabular}

aData shown are the average of 20,15, 10 and 5 independent measurements (containers) per treatment for week 1, 2, 3 and 4, respectively. 
Chapter 5

Table S3. Volatile acids produced as a function of time during an anaerobic soil disinfection laboratory experiment in the Netherlands for four weeks at $24^{\circ} \mathrm{C}$. Containers were filled with soil amended or non-amended with Herbie ${ }^{\circ}$.

\begin{tabular}{|c|c|c|}
\hline \multirow[t]{2}{*}{ Volatile fatty acid } & \multicolumn{2}{|c|}{ Treatment $^{a}$} \\
\hline & + TR4, + Herbie ${ }^{\circ}$, sealed & + TR4, - Herbie ${ }^{\circ}$, sealed \\
\hline \multicolumn{3}{|l|}{ Acetic $\left(n m o l ~ L^{-1}\right)$} \\
\hline 1 week & 6.002 & 0.18 \\
\hline 2 week & 7.706 & 0.292 \\
\hline 3 week & 8.582 & 0.078 \\
\hline 4 week & 8.086 & 0.134 \\
\hline \multicolumn{3}{|c|}{ Propionic (nmol L-1) } \\
\hline 1 week & 1.026 & 0.056 \\
\hline 2 week & 1.876 & 0.138 \\
\hline 3 week & 2.128 & 0.036 \\
\hline 4 week & 2.378 & 0.028 \\
\hline \multicolumn{3}{|l|}{ Butyric (nmol L-1) } \\
\hline 1 week & 1.758 & 0.048 \\
\hline 2 week & 2.186 & 0.088 \\
\hline 3 week & 2.552 & 0.032 \\
\hline 4 week & 2.956 & 0.034 \\
\hline \multicolumn{3}{|c|}{ Iso-butyric (nmol L-1) } \\
\hline 1 week & 0.072 & 0.01 \\
\hline 2 week & 0.176 & 0.042 \\
\hline 3 week & 0.24 & 0.012 \\
\hline 4 week & 0.318 & 0.006 \\
\hline \multicolumn{3}{|l|}{ Valeric (nmol L-1) } \\
\hline 1 week & 0.06 & 0.032 \\
\hline 2 week & 0.074 & 0.088 \\
\hline 3 week & 0.082 & 0.05 \\
\hline 4 week & 0.122 & 0.022 \\
\hline \multicolumn{3}{|c|}{ Iso- valeric (nmol L-1) } \\
\hline 1 week & 0.072 & 0.024 \\
\hline 2 week & 0.11 & 0.068 \\
\hline 3 week & 0.114 & 0.03 \\
\hline 4 week & 0.152 & 0.016 \\
\hline
\end{tabular}

${ }^{a}$ Data shown are the average of five independent measurements (containers) per treatment per week 


\section{References}

Anonymous, 2013. http://www.sun.ac.za/english/faculty/agri/plant-pathology/ac4tr4/foc-tr4-inafrica/history

Australia Department of Agriculture and Water Resources. Date accessed 16 April 2019. http://www. agriculture.gov.au/pests-diseases-weeds/plant/panama-disease-tropical-race-4\#secure-anysuspect-specimens

Baayen, R.P. O'Donnell, K., Bonants, P.J.M., Cigelnik, E., Kroon, L.P.N.M., Roebroeck, E.J.A. and Waalwijk, C. (2000) Gene genealogies and AFLP analyses in the Fusarium oxysporum complex identify monophyletic and non-monophyletic formae speciales causing wilt and rot disease. Phytopathology 9: 891-900.

Bebber, D., Holmes, T. and Gurr, S.J. (2013) The global spread of crop pests and pathogens. Global Ecology and Biogeography 23:1398-1407.

Bleeker, P.O. (2008) Onderzoek naar de beheersing van meerjarige onkruiden. PPO-AGV, Lelystad, The Netherlands, Report 32500313:25.

Blok, W.J., Lamers, J.G., Termorshuizen, A.J. and Bollen, G.J. (2000) Control of soilborne plant pathogens by incorporating fresh organic amendments followed by tarping. Phytopathology 90:253-259.

Browning, M., Wallace, D.B. Dawson, C., Alm, S.R. and Amador, J.A. (2006) Potential of butyric acid for control of soil-borne fungal pathogens and nematodes affecting strawberries. Soil Biology Biochemistry 38:401-404.

Butler, D.M., Burelle, K.N., Muramoto, J., Shennan, C., McCollum, T.G. and Rosskopf, E.N. (2012a) Impact of anaerobic soil disinfestation combined with soil solarization on plant-parasitic nematodes and introduced inoculum of soilborne plant pathogens in raised bed vegetable production.Crop Protection 39:33-40.

Butler, D.M., Rosskopf, E.N., Kokalis-Burelle, N., Albano, J., Muramoto, J., Shennan, C. (2012b) Exploring the warm-season cover crops as carbon sources for anaerobic soil disinfestation (ASD). Plant Soil 355:149-165.

Carvalho, D.D.C., Marques de Mello, S.C., Martins, I. and Lobo Jr., M. Biological control of Fusarium wilt in common beans by in-furrow application of Trichoderma harzianum. Tropical Plant Pathology 40:375-381.

Chittarath, K., Mostert, D., Crew, K. S., Viljoen, A., Kong, G., Molina, G., \& Thomas, J. E. (2017). First report of Fusarium oxysporum f.sp. cubense tropical race 4 (VCG 01213/16) associated with Cavendish bananas in Laos. Plant Diease.

Churchill, A.C.L. (2011) Mycosphaerella fijiensis, the black leaf streak pathogen of banana: progress towards understanding pathogen biology and detection, disease development, and the challenges of control. Molecular Plant Pathology 12(4):307-328.

Cianchetta, A. N. and Davis, R.M. (2015) Fusarium wilt of cotton: Management strategies. Crop Protection 73: 40-44.

Cook, R.J. and Baker, K.F. (1983) The nature and practice of biological control of plant pathogens. St. Paul, MN, USA: The American Phytopathological Society.

Duniway,J.M.(2002) Status of chemical alternatives to methyl bromide for pre-plant fumigation of soil. Phytopathology 92:1337-1343.

Fisher, M.C., Henk, D.A., Briggs, C.J., Brownstein, J.S., Madoff, L.C., McCraw, S.L. and Gurr, S.J. (2012) 
Emerging fungal threats to animal, plant and ecosystem health. Nature 484:186-194.

Fu, L., Ruan, Y., Tao, C., Li, R., and Shen, Q. (2016) Continuous application of bioorganic fertilizer induced resilient culturable bacteria community associated with banana Fusarium wilt suppression. Scientific reports 6: 27731.

Garcia, F.A., Bakry, F., Irish, B.M. and Kema, G.H.J. (2019) Resistance in banana to Fusarium spp. causing Panama disease: Triploid, Diploid and Hybrid accessions. PhD thesis, Wageningen University and Research, Wageningen, The Netherlands.

Garcia-Bastidas, F., Ordoñez , N., Konkol, J., Al-Qasim, M., Nazer, Z., Abdelwali, M., Salem, N., Waalwijk, C., Ploetz, R., and Kema G.H.J. (2015) First report of Fusarium oxysporum f.sp. cubense tropical race 4 associated with Panama disease in banana outside southeast Asia. Plant disease 98 (5): 694.

Gilardi, G., Ortega, S.F., van Rijswick, P.C.J., Ortu, G., Gullino, M.L.and Garibaldi, A. (2017) A new race of Fusarium oxysporum f.sp. lactucae of lettuce. Plant Pathology 66:677-688.

Gilchrist, J.E., Campbell, J.E., Donnelly, C.B., Peeler, J.T. and Delaney, J.M. (1973) Spiral Plate Method for Bacterial Determination. Applied Microbiology 25 (2): 244-252.

Goud, J.C., Termorshuizen, A.J., Blok, W.J., and van Bruggen, A.H.C. (2003) Long-term effect of biological soil disinfestations on Verticillium wilt. Plant Disease 88:688-694.

Gurtler, J.B. (2017) Pathogen Decontamination of Food Crop Soil: A Review. Journal of Food Protection 80 (9): 1461-1470.

Huang, X., Teng, W., Jinbo, Z., Lei, M., Tongbin, Z. and Zucong, C. (2015) Toxic organic acids produced in biological soil disinfestation mainly caused the suppression of Fusarium oxysporum f.sp. cubense. BioControl 60:113-124.

Huang, S-C. and Ko, W-H. (2004) Cavendish banana cultivars resistant to Fusarium wilt acquired through somaclonal variation in Taiwan. The American Phytopathological Society 88:580-588.

Hung, T. N., Hung, N. Q., Mostert, D., Viljoen, A., Chao, C. P., \& Molina, G. (2017). First report of Fusarium wilt on Cavendish bananas, caused by Fusarium oxysporum f.sp. cubense tropical race 4 (VCG 01213/16), in Vietnam. Plant Disease.

Imazaki, I. and Kadota, I. (2019) Control of Fusarium wilt of melon by combined treatment with biocontrol, plant-activating and soil-alkalizing agents. Journal of General Plant Pathology 85:128-141.

J. E. Gilchrist, J. E. Campbell, C. B. Donnelly, J. T. Peelerand J. M. DelaneyELANEY. (1973) Spiral Plate Method for Bacterial Determination. Applied Microbiology 25(2): 244-252.

Jansma, J.E., Vlaming, E.A.C., Boer, M. De and Blok, W. (2001) Biologische grondontsmetting. Ekoland, the Netherlands 21:26-27.

Katan, J. (2000) Physical and cultural methods for the management of soil-borne pathogens. Crop Prot., 19:725-731.

Koike, S.T. and Gordon, T.R. (2015) Management of Fusarium wilt of strawberry. Crop Protection 73: 67-72.

Lamers, J.G., Blok, W.J., and Termorshuizen, A.J. (2000) Biological soil disinfestations to control Fusarium oxysporum f.sp. asparagi in Dutch asparagus fields. In: Abstracts of Symposium on chemical and non-chemical soil and substrate disinfestations, Torino, Italy,p.15

Lamers, J.G., Runia, W.T., Molendijk, L.P.G. and Bleeker, P.O. (2010) Perspectives of Anaerobic soil disinfestations. In: Gamliel et al. (eds.). Proc. VII IS on Chem. And Non-chem. Soil and Substrate Disinfestation. Acta Horticulture 883.

Laurence, M.H., Summerell, B. A., Burgess, L.W., and Liew E.C. (2014) Genealogical concordance 
phylogenetic species recognition in the Fusarium oxysporum species complex. Fungal Biology 118(4)374-384.

Levine, A.S. and Fellers, C.R. (1940) Action of acetic acid on food spoilage microorganisms. Journal of Bacteriology 39(5): 499-515.

Lian,J., Wang Z.F., Cao, L.X., Tan, H.M., Inderbitzin, P., Jiang, Z.D., Zhou, S.N. (2009) Artificial inoculation of banana tissue culture plantlets with indigenous endophytes originally derived from native banana plants. Biological Control 51:427-434.

Marquardt, S. (2001) "Green Havoc": Panama disease, Environmental Change and Labor Process in the Central American Banana Industry. The American historical review 106 (1): 49-80.

Maymon, M. Shpatz, U., Shpatz, U., Harel, , Y.M., Levy, E., Elkind, , G., Teverovsky, E.,..... Israeli, Y. and Freeman, S. (2018) First Report of Fusarium oxysporum f. sp. Cubense Tropical Race 4 Causing Fusarium Wilt of Cavendish Bananas in Israel. Plant Disease 102 (12), pp 2655.

Mazzola, M., Hewavitharana, S.S., Strauss, S.L., Shennan, C. and Muramoto, J. (2016) Anaerobic Soil Disinfestation and Brassica Seed Meal Amendment Alter Soil Microbiology and System Resistance. International Journal of Fruit Science 16:47-58.

McCarty, D.G., Ownley, B.H., Wszelaki, A.L., Sams, C.E., Butler, D.M. (2012) Evaluation of anaerobic soil disinfestation (ASD) for warm-season vegetable production in Tennessee. Horticultural Science 47:330-331.

Messiha, N.A.S., van Diepeningen, A.D., Wenneker, M., van Beuningen, A.R., Janse, J.D., Coenen, T.G.C., Termorshuizen, A>J., van Bruggen, A.H.C. and Blok, W.J. (2007) Biological Soil Disinfestation (BSD), a new control method for potato brown rot, caused by Ralstonia solanacearum race 3 biovar 2. European Journal of Plant Pathology 117:403-415.

Momma, N. (2008) Biological Soil Disinfestation (BSD) of Soilborne Pathogens and Its Possible Mechanisms. Japan Agricultural Research 42(1):7-12.

Momma, N. (2015) Studies on mechanisms of anaerobicity-mediated biological soil disinfestation and its practical application. Journal of General Plant Pathology 81:480-482.

Momma, N., Kobara, Y., Uematsu, S., Kita, N., and Shinmura, A. (2013) Development of biological soil disinfestations in Japan. Applied Microbiology Biotechnology 97:3801-3809.

Momma, N., Usami, T., Amemiya, A., and Shishido, M. (2005) Factors involved in the suppression of Fusarium oxysporum f.sp. lycopersici by soil reduction. Soil Microorganism 59:27-33

Momma, N., Usami, T., and Shishido, M. (2007) Detection of Clostridium sp. inducing biological soil disinfestation (BSD) and suppression of pathogens causing Fusarium wilt and bacterial wilt of tomato by gases evolved during BSD. Soil Microorganism 61 (1):3-9.

Momma, N., Yamamoto, K., Peter Simandi, M.S. (2006) Role of organic acids in the mechanisms of biological soil disinfestation (BSD). Journal of General Plant Pathology 72:247-252.

Mostert, D., Molina, A. B., Daniells, J., Fourie, G., Hermanto, C., Chao, C. P., . . Viljoen, A. (2017). The distribution and host range of the banana Fusarium wilt fungus, Fusarium oxysporum f.sp. cubense, in Asia. PLoS One 12(7), 1-24.

Mowlick, S., Hirota, K., Takehara, T., Kaku, N., Ueki, K.,Ueki, A. (2012a) Development of anaerobic bacterial community consisted of diverse Clostridial species during biological soil disinfestations amended with plant biomass. Soil Science Plant Nutrition 58:273-287.

Mowlick, S., Inoue, T., Takehara, T., Kaku, N., Ueki, K.,Ueki, A. (2013) Changes and recovery of soil bacterial communities influenced by biological soil disinfestation as compared with chloropicrintreatment. AMB Express 3:46. 
Mowlick, S., Inoue, T., Takehara, T., Tonouchi, A., Kaku, N., Ueki, K. and Ueki, A. (2014) Usefulness of Japanese-radish residue in biological soil disinfestation to supress spinach wilt disease accompanying with proliferation of soil bacteria in the Firmicutes. Crop Protection 61:64-73.

Mowlick, S., Takehara, T., Kaku, N., Ueki, K.,Ueki, A. (2012b) Proliferation of diversified Clostridial species during biological soil disinfestation incorporated with plant biomass under various conditions. Applied Microbiology Biotechnology

Muramoto, J., Shennan, C., et al....Pugliese, M. (2014) Optimizing anaerobic soil disinfestation for California strawberries. Acta Horticulturae 1044:215-220.

Okazaki, H. and Nose, K. (1986) Acetic acid and n-butyric acid as causal agents of fungicidal activity of glucose-amended flooded soil (in Japanese). Japan Phytopathology 52:384-393.

O'Neill, W. T., Henderson, J., Pattemore, J. A., O'Dwyer, C., Perry, S., Beasley, D. R., et al. (2016). Detection of Fusarium oxysporum f. sp. cubensetropical race 4 strain in northern Queensland. Australasian Plant Disease Notes. 11:33.

Ordoñez, N., Seidl M.F., Waalwijk C., Drenth A., Kilian A., Thomma B.P.H.J., et al. (2015) Worse Comes to Worst: Bananas and Panama Disease-When Plant and Pathogen Clones Meet. PLoS Pathog 11(11): e1005197.

Ordoñez, N., García-Bastidas F., Laghari, H. B. ., Akkary, M. Y., Harfouche, E. N., and al Awar, B. N., and Kema, G. H. J. (2016) First report of Fusarium oxysporum f.sp. cubense tropical race 4 causing Panama disease in Cavendish bananas in Pakistan and Lebanon. Disease Notes 100 (1): 209

Ploetz, R.C. (2000) Panama disease: A classic and destructive disease of banana. Plant health progress. Accessed at https://www.plantmanagementnetwork.org/pub/php/management/ bananapanama/.

Ploetz, R.C. (2006) Fusarium wilt in banana is caused by several pathogens referred to as Fusarium oxysporum f.sp. cubense. Phytopathology 96:653-656.

Ploetz, R.C. (2015a) Fusarium wilt of banana. Phytopathology 105:1512-1521.

Ploetz, R.C. (2015b) Management of Fusarium wilt of banana: a review with special reference to tropical race 4. Crop Protection 73:7-15.

Ploetz, R.C., Kema, G.H. and Ma, L.J. (2015) Impact of diseases on export and smallholder production of banana. Annual Review Phytopathology 53:269-288.

Prather, M.J. McElroy, M.B. and Wofsy, S.C. (1984) Reductions in ozone at high concentrations of stratospheric halogens. Nature 312:227-231.

Raman, R. (2017) The impact of Genetically Modified (GM) crops in modern agriculture: A review. GM Crops \& Food 8:4, 195-208.

Ristaino, J.B. and Thomas W. (1997) Agriculture, methyl bromide, and the ozone hole: can we fill the gaps. Plant Disease 81:954-975.

Runia, W.T., Thoden, T.C., Molendijk, L.P.G., van den Berg, W., Streminska, M.A., van der Wurff, A.W.G., Termorshuizen, A.J., Feil, H., and Meints, H. (2014) Unravelling the mechanism of pathogen inactivation during Anaerobic Soil Disinfestation. Proc. VIII IS on Chemical and non-chemical soil and substrate disinfestation. Acta Hort., 1044 ISHS.

Shennan, C., Muramoto, J., Koike, S., Bolda, M., Daugovish, O., Mochizuki, M., Klonsky, K., Rosskopf E.N., Kokalis-Burelle, N. and Butler, D.M. (2011) Anaerobic soil disinfestation for suppressing Verticillium dahliae in strawberry production in California. Horticultural Science 46:147-175.

Shennan, C., Muramoto, J., Lamers, J., et al....Pugliese, M. (2014) Anaerobic soil disinfestation for soil borne disease control in strawberry and vegetable systems: Current knowledge and future 
directions. Acta Horticulturae 1044:165-175.

Shinmura, A. (2004) Principle and effect of soil sterilization method by reducing the redox potential of soil. The Phytopathological Society of Japan (PSJ) Soilborne Disease Workshop Report 22:2-12.

Stover, R.H. (1979) Flooding of soil for disease control. Pages 19-28 in: Soil Disinfestation. D. Mulder (ed.) Elsevier Scientific Publishing Company, Amsterdam, The Netherlands.

Strange, R.N. and Scott, P.R. (2005) Plant disease: A threat to global food security. Annual Review Phytopathology 43:83-116.

Strauss, S.L. and Kluepfel D.A. (2015) Anaerobic soil disinfestation: A chemical-independent approach to pre-plant control of plant pathogens. Journal of Integrative Agriculture 14(11):2309-2318.

Subbarao, K.V. (2002) Methyl bromide alternatives - meeting the deadline. Phytopathology 92:13341343.

Termorshuizen, A.J., Blok, W.J. and Lamers, J.G. (2000) Biological soil disinfestation to control Verticillium dahliae by incorporation of fresh organic material followed by plastic mulching. P. 328-331. In: E.C. Tjamos et al., Advances in Verticillium research and disease management, APS Press St. Paul, Minnesota.

Thangavelu, R., Mostert, D., Gopi, M., Ganga Devi, P., Padmanaban, B., Molina, A.B. and Viljoen, A. (2019) First detection of Fusarium oxysporum f. sp. cubense tropical race 4 (TR4) on Cavendish banana in India. European Journal of Plant Pathology.

Thanning, C. And Gerhardson, B. (2001) Reduced sclerotial soil-longevity by whole-crop amendment and plastic covering. Journal of Plant Diseases and Protection 108:143-151.

Yuan, J., Li, B, Zhang, N., Waseem, R., Shen, Q., Huang, Q. (2012) Production of Bacillomycin- and Macrolactin-type antibiotics by Bacillus amyloliquefaciens NJN-6 for suppressing soilborne plant pathogens. Journal of Agriculture and Food Chemistry 60: 2976-2981. 

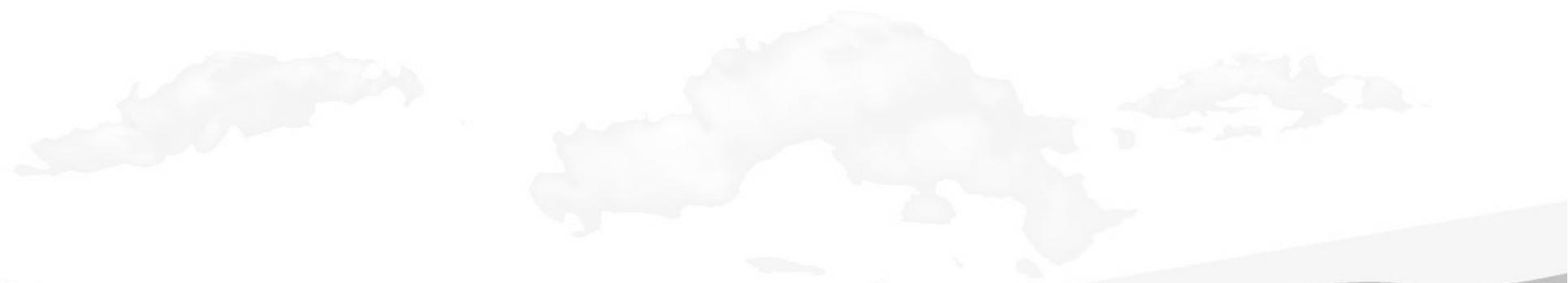

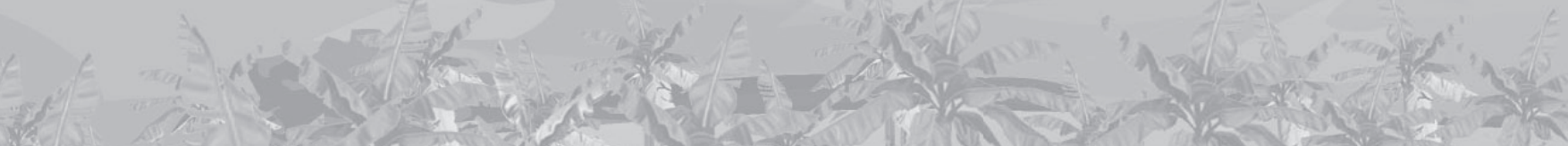

1.

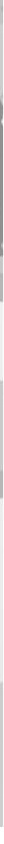




\section{CHAPTER 6}

\section{General discussion}





\section{Introduction}

Abiotic and biotic stressors, including pests and diseases, pose a significant impact on food security (Fisher et al., 2012; Bebber et al., 2014). Crop losses deprive humanity an estimated $10-16 \%$ of the attainable yield with an annual cost approximating US\$ 220 billion (Oerke, 2006). As the sensitivity to crop protection agents has significantly reduced (Fisher et al., 2012), these devastations might prolong, leading to societal and political unrest (Ploetz, 2015a). Banana, including sweet and cooking bananas, belongs to the top five most important staple and cash crops (Ploetz et al., 2003; Aurore et al., 2009). Currently, banana is in jeopardy due to a re-occurring Fusarium wilt or Panama disease epidemic (Butler, 2013) affecting a wide range of commercial and sustenance banana varieties (Garcia, 2019). The clonal (Ordóñez et al., 2015) fungal pathogen Fusarium odoratissimum, a new species comprising a few genotypes, including the so-called called tropical race 4 (TR4) (Maryani et al., 2019) is the culprit of this epidemic. The species is continuously expanding its area and hence, the epidemic has moved outside the center of origin in Southeast Asia (Garcia et al., 2014) leaving devastations at thousands of hectares of banana plantations (Chittarath et al., 2017; Hung et al., 2017; Li et al., 2013; Molina et al., 2009; Mostert et al., 2017; Ordóñez et al., 2015; Ordóñez et al., 2016; Ploetz et al., 2015; Thangavelu et al., 2019; Zheng et al., 2018). Economic damage caused by Panama disease will be disastrous once TR4 will devastate the major export banana plantations in South America (Ploetz, 2000; 2006) specially with the recent detection in Colombia (https://www.sciencemag.org/ news/2019/07/devastating-banana-disease-may-have-reached-latin-america-could-driveglobal-prices). Evidently, there is a need for immediate action on how to control and stop this epidemic before it is too late.

Located within the centre of banana diversity, the Philippines holds a wide variety of bananas grown all over the archipelago both for local consumption and the export trade (Valmayor et al., 2000). The country is a significant player in the Cavendish banana export along with Ecuador, Guatemala, Costa Rica, Colombia, Mexico, Dominican Republic and Peru (FAOSTAT, 2017). But unlike the South American banana producing countries, the country has been confronted with the presence of TR4 for a decade, particularly in the Cavendish banana belt of Mindanao (Molina et al., 2009; Mostert et al., 2017). Since, the export declines and growers increasingly cultivate new scarce areas (PBGEA, 2017) I hypothesized that the management strategies against Panama disease are apparently ineffective or insufficiently applied resulting in continued dissemination of TR4 despite the efforts to stop the epidemic along with governmental and industrial awareness and extension programs. This thesis describes various practical aspects of the epidemiology of TR4 in the Philippines, thereby substantiating the uncertainty about the continued dispersal of the pathogen.

\section{Continuous TR4 spread: failure of containment strategies?}

The on-going TR4 incursions mentioned above and the latest report on an incidence in the United Kingdom (Anonymous, 2018) and the final leap into Latin America, https:// 
www.sciencemag.org/news/2019/07/devastating-banana-disease-may-have-reachedlatin-america-could-drive-global-prices, is a manifestation of the invasion success of TR4. Its dispersal can be attributed by both biotic and abiotic agents. The big question for now is when will this spread stop? Have we reached the point of maximum deliberation? TR4 infestation was initially ignored, arguably due to lack of knowledge. Like any other soilborne pathogen, Panama disease diagnosis through visual inspection is indeed a challenge due to non-distinct above-ground symptoms and resemblance with symptoms caused by drought, stress or nutrient deficiency (Raaijmakers et al., 2009). Classical laboratorybased identification and vegetative compatibility group (VCG) testing were employed for disease diagnosis (Leslie \& Summerell, 2006). However, the most important shortcomings of this procedure are the lengthy and cumbersome biological experiments that frequently result in unspecific variation and hence unambiguous identification of TR4, resulting in false positives/negatives (García et al., 2014; Leslie \& Summerell, 2006). DNA-based diagnostics, on the contrary, are rapid, highly specific and reproducible, but also require equipment, training or protocols coming with commercial kits to standardize diagnosis. Molecular detection based on conventional PCR developed by Dita et al. (2010) was used to confirm various new incursions (Garcia et al., 2014; Ordóñez et al., 2015; Ordóñez et al., 2016; Zheng et al., 2018) and was the tipping point towards new insights and major investments in research and development in the Netherlands and elsewhere. Alternative molecular diagnostic tools were also developed, such as conventional PCR (Lin et al., 2009), real time-PCR (Aguayo et al., 2017; Lin et al., 2013; Yang et al; 2015), loop mediated isothermal amplification (LAMP) (Li et al., 2013; Zhang et al., 2013), real-time LAMP (Peng et al., 2014) and insulated isothermal PCR (Lin et al., 2016). However, these diagnostic tools were developed on a limited set of target and non-target isolates and lacked validation on a global collection of TR4 isolates, which ultimately affects the specificity and sensitivity of these assays, particularly for environmental samples, rendering them useless. Our developed TR4 diagnostic tool, is checked on hundreds of Fusarium isolates and meets the specificity, sensitivity and repeatability requirements (Chapter 2). Moreover, it is suitable for on-site diagnosis. Hence, detection of new incursions or routine farm monitoring is now possible in the Philippines. Evidently, quantitative diagnosis is equally important to evaluate the efficacy of management practices as a function of TR4 quantity in substrates. We, therefore, developed a TaqMan probe-based quantitative PCR to detect TR4 in different substrates, such as water and soil, which is imperative to chart the dispersal and quantity of TR4 propagules (Chapter 3 and 5). However, molecular diagnostics for other Fusarium spp. causing Panama disease is not yet at hand and is indispensable to unambiguously diagnose causal Fusarium spp. in different banana cultivars.

Dispersal by human intervention through movement of infected planting material is deemed to be one of the most important factors in short and long distance TR4 dissemination. This is reminiscent of the spread of Fusarium spp. race 1 strains in the previous century in South America that devastated cv. Gros Michel based industry (Stover, 1962; Marquardt, 2001; Soluri, 2002). These race 1 strains belong to various Fusarium spp., which are even not all known (Maryani et al., 2018). In China and the Greater Mekong Basin, the rapid spread 
of TR4 is associated with the movement of infected planting material, equipment and the lack of strict quarantine measures. This eventually resulted in a TR4 zone reaching from the Eastern province of Fijuan to the Southern provinces of Guangdong, Hainan and from there to the Southwestern provinces Guangxi and Yunnan (Chittarath et al., 2017; Hung et al., 2017; Li et al., 2013; Molina et al., 2009; Mostert et al., 2017; Xu et al., 2003; Zheng et al., 2018). Expanding cultivation in surrounding countries, such as Vietnam, Laos and Myanmar is driven by the increasing demand of the Chinese market along with reduced yields due to manifold TR4 infestations in these areas. Clearly, this also facilitates international dispersal of TR4 (Zheng et al., 2018). Moreover, farmers who do not have access to tissue culture plantlets, might resort to use symptomless but infected suckers thereby intensifying the spread of the disease. This also applies for the recent emergence of the bacterium Xylella fastidiosa infecting olive trees in Italy, which is believed to be introduced via contaminated plant material from Costa Rica (Almeida, 2016). International trade also resulted in the introduction of Phytophthora plurivora from Europe to the USA by trading diseased nursery plant material (Schoebel et al., 2014). Also, the Moko disease of banana was allegedly introduced in the Philippines through infected 'Valery' (AAA Cavendish subgroup) planting material from Central America (Blomme et al., 2017; Rillo, 1979; Buddenhagen, 1994). To further complicate this, human migration with mud-stained footwear contaminated with TR4-infested soil can greatly contribute to local, regional or intercontinental spread (Dita et al., 2018; Ploetz, 2015), similar to the accidental spore transport of Puccinia striiformis $\mathrm{f}$. sp. tritici in Australia from Europe through contaminated clothing or goods (Wellings, 2007). We tested soil attached to footwear used in China and Philippines positive for TR4 (Chapter 3), where disease pressure is high given the presence of large commercial Cavendish plantations. These sizable farms have the advantage and resources to prevent disease dissemination through biosecurity measures i.e. quarantine baths but their efficacy to stop further dissemination is low, despite the substantial costs for implementing and maintaining such units. Moreover, we have now for the first time show the distribution of TR4 across one-meter vertical columns of soil. In addition, the efficacy of disinfectants used in the quarantine baths depends on exposure time and substrate, particularly since it significantly drops in the presence of soil (Chapter 4). Taken together, the first line of defense against TR4 dispersal frequently fails, as recently observed in the Philippines and other TR4 affected countries (Zheng et al., 2018). This is even more complicated for small-scale farmers who either lack the know-how or have limited resources to install quarantine baths.

The inoculum density in naturally infested soil was significantly lower than our artificially inoculated control soil. This brings up the question about the actual threshold inoculum that is required for disease development and to spread the epidemic. As described by Baker (1978), the pathogen inoculum density - plant host response relationship (inoculum density-disease incidence) showed a strong relationship between the soil inoculum and disease (Figure 1). After a lay fallow period and cultivation of susceptible banana will ensue, TR4 might undergo a latent period (period of time from infection to symptom expression) followed by an infectious period during which inoculum is produced (Gilligan, 1994). Then, an exponential increase of TR4 will follow as a function of time until the critical threshold 
is achieved after defeating the host innate immune response and as a result disease appears. The susceptible banana Cavendish cv. Williams and Lady Finger (AAB) were used to demonstrate colonization of the roots by the subtropical race 4 and subsequent movement through the plant prior to the manifestation of symptoms. The increasing abundance of pathogen mycelium in the xylem vessels as a function of time leads to the appearance of wilting symptoms in the leaf (Warman and Aitken, 2018). This population dynamics of TR4 is directly linked with the polycyclic nature of the disease (Ploetz, 2015), which contributes to the differences in degree of infestations in different areas and greatly affects the efficacy of any management strategy (Chapter 4 and 5). Hence, determining TR4 quantities in any given substrate is required to better plan and execute quarantine strategies.

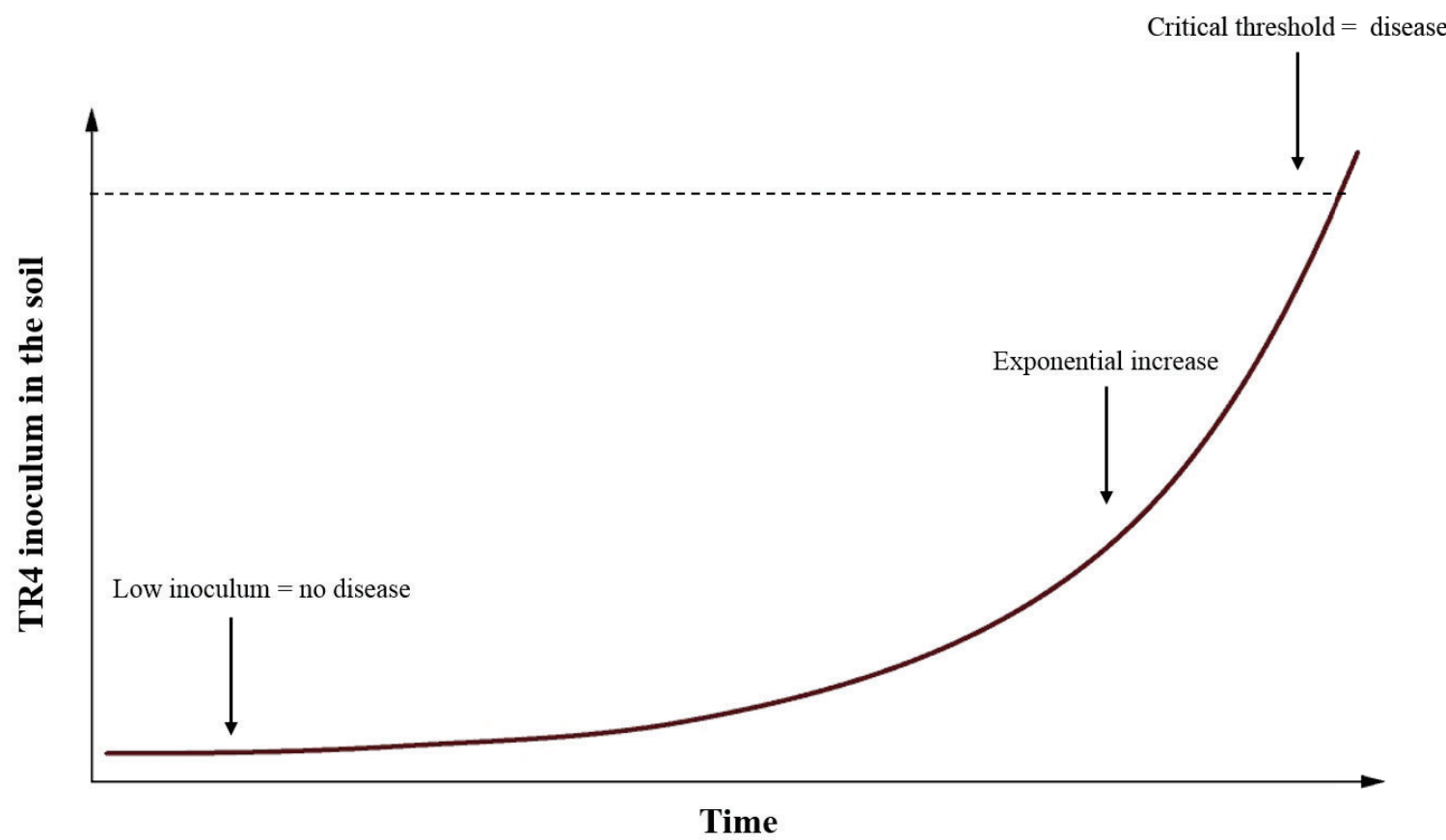

Figure 1. Exponential increase of Fusarium odoratissimum tropical race 4 inoculum in a susceptible banana crop without environmental, biological or chemical barriers. In the absence of susceptible plants, inoculum build-up will lag by the production of persistent chlamydospores or by invading non-hosts as an endophyte. Once susceptible banana cultivation ensues, inoculum production will be regained until a critical threshold is reached that disables control and eventually results in crop collapse.

A further complicating factor is that TR4 is a soil-borne fungal pathogen, which is able to act as endophyte in weeds and other plant species in the absence of banana hosts (Hennessy et al., 2005; Su et al.,1986; Waite and Dunlap, 1953, Chapter 3). This aspect was partly neglected and can potentially nullify any targeted control strategy and greatly affects disease dynamics. If the density dependence of TR4 inoculum in soil is host related, then this 
mutualistic relationship with weeds might pose a non-quantifiable consequence. In previous studies on other Fusarium spp. inoculum build-up in the rhizosphere was not observed in alternative hosts (Banihashemi and de Zeeuw, 1975). This is further supported by the fact that these weeds did not show wilting symptoms. We now for the first time detected TR4 in the aboveground parts of the weeds in areas abandoned due to Panama disease and in the absence of banana hosts, which proved that these non-host plants contribute to the survival potential of TR4 by acting as green bridge (Burdon and Thrall, 2007) (Chapter 3). Alternative hosts have been reported as well for other banana diseases that plays a critical role in the perpetuation of disease. Ralstonia syzygii subsp. celebesensis causing banana blood disease used Heliconia species as alternate hosts (Elphinstone, 2005; Blomme et al., 2017). R. solanacearum causing Moko disease was isolated from Heliconia species in Coto valley virgin forests in southwest Costa Rica (Sequeira and Averre, 1961). This bacteria has a wide host range though (Belalcazar et al., 2004) to include Solanaceous species influencing the efficacy of lay fallow as disease management strategy. Therefore, elimination of weeds acting as alternative hosts is highly recommended specially during lay fallow period (Romo et al., 2012). Maintaining a critical level of inoculum in alternative hosts can act as a foundation for kicking off accelerated population dynamics in soil once banana cultivation ensues, even after a lagging period of inoculum build-up (Figure 1).

The emergence of TR4 enforces a reformation of banana cultivation (Dita et al, 2018), including abandoning surface water for irrigation and a shift to underground water resources. This is rooted in the idea that water, including rain runoff, may act as vector of fungal dispersal (Golan and Pringle, 2017; Ploetz, 2015) like in the case of other Fusarium spp. (Palmero et al, 2009). It was noted that aquatic environments can be a good carrier for fungal dispersal eliminating the possibility for desiccation, UV damage and harsh temperatures as in water temperature drops slower than in air (Golan and Pringle, 2017). In China, the rapid spread of TR4 was associated with contamination of irrigation water from the Pearl river (Xu et al., 2003). In Mozambique, it was reported that the intensification of TR4 spread was the result of heavy rainfall resulting to flooding (Anonymous, 2015). This was also the case in the Philippines wherein upsurge of disease spread ensued after the destructive typhoon Pablo in 2012, leading to overflowing of river water in nearby banana farms (Figure 2). The propagules of other soil-borne pathogens such as Phytophthora spp. are also reported to spread through streams and irrigation ponds (Davidson et al., 2005). Indeed, our study proved TR4 contamination of irrigation water sourced from rivers and reservoirs used as irrigation water in one of the commercial banana plantations in Mindanao (Chapter 3). As a result, information-guided decisions were made by shifting to underground water sources as a safer option. However, this entails huge investments, which cannot be buffered by small-scale farmers. The scenario where the need to irrigate is high to increase productivity is discouraging for them. In addition, sourcing underground water for irrigation could result in social problems and competing claims, particularly due to the water availability for household use and ecological trade-offs (Skiadaresis et al., 2019).

The dispersal of TR4 operates at multiple spatial and temporal scales and is mediated by 
different vectors. Its compounded impact and devastation shape the banana industry strategy to relocate and install farms in new disease-free areas. As sketched above, this is currently happening in China where vast land areas were abandoned due to TR4 infestations (Li et al., 2013). As a result, investors moved to neighbouring countries such as Vietnam, Laos, Myanmar for banana cultivation. As a consequence, the disease also moved to these areas most probably due to movement of planting materials, vehicles and other farm implements (Zheng et al., 2018). Similarly, in the Philippines, Chinese banana traders are buying and exporting banana from the Philippines, thereby contributing to farms expansions of local farmers even in hotspot areas for Panama disease. By neglecting the epidemiological consequences of these strategies, such policies disturb the on-going battle against Panama disease and thereby facilitate the further dispersal of the pathogen as recently evidenced by the incursion of TR4 into Colombia (https://www.sciencemag.org/news/2019/07/ devastating-banana-disease-may-have-reached-latin-america-could-drive-global-prices).

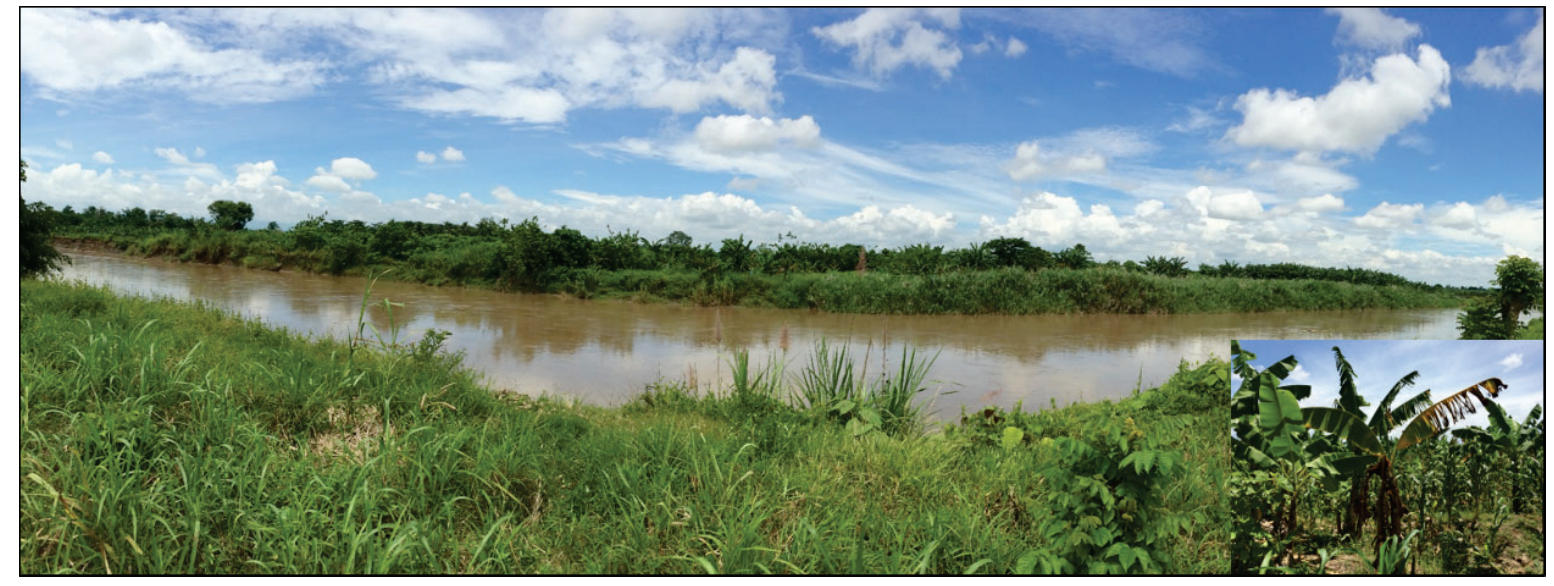

Figure 2. Overflowing of river water in the nearby banana farms in Mindanao, Philippines, resulted in rapid dissemination of TR4 propagules causing Panama disease in banana. As a consequence, banana cultivation was not feasible due to heavy infestation causing abandonment of farms.

\section{Disease control by all means}

Soil-borne pathogens are difficult to control due to their complex occurrence in the heterogeneous soil that impedes the efficacy of any cultural or chemical treatment or by competing with microbiological agents (Katan, 2000; Huang et al., 2019). It is even more complicated for Panama disease due to the vast monocropping of banana on thousands of hectares resulting in the massive build-up of pathogen inoculum in soils (Katan, 2017). There has been much to learn from the previous Panama disease epidemic caused by Fusarium spp. in the Gros Michel banana belts of in South America (Soluri, 2000; Marquardt, 2002). The banana companies' strategy was to stay ahead of the disease by claiming new land but eventually this did not work since they simply ran out of clean land resulting in the collapse of the Gros Michel based banana industry (Ploetz, 2008; Stover, 1962). The fear is that the industry has not learnt from history, which consequently will lead to another Panama 
disease pandemic (Ploetz, 2015). Out of desperation, several management strategies have been adopted and deployed that are insufficiently supported by data and hence, result in an arm race of different uncoordinated strategies to manage the problem. This is neither economical nor effective and calls for governmental interventions to secure the banana industry.

In order to achieve concrete solutions, management strategies should take into account genotype $x$ environment interactions (Katan, 2017). As suggested by Chellemi et al. (2016), a systematic approach to manage soil-borne pathogens should entail four principal pillars; (1) inhibit the introduction and spread of the pathogen in the crop system, (2) minimize inoculum density to levels that can be managed, (3) improve soil suppressiveness and (4) minimize the impact of destructive activities such as pesticide and other chemical application by employing integrated pest management strategies. Recently, Dita et al. (2018) reviewed the knowledge on Panama disease epidemiology and suggested that it is important to address the major gaps of knowledge revolving around its short distance spatial dynamics (anthropogenic and other factors such as water, contaminated soil and alternative hosts species) and long distance dispersal (anthropogenic-related factors). Hence, in this thesis, the factors contributing to pathogen dispersal in the Philippines were addressed and will be the basis for implementing applicable disease management strategies.

Deployment of biosecurity measures was used as first line of defense to prevent the introduction or movement of the pathogen within and between farms. Therefore, quarantine baths i.e. tire and footwear baths were installed at farm entry points. Several disinfectants with different active ingredients were efficacious under in vitro conditions when tested against conidia and soil-chlamydospores suspensions of the causal Fusarium spp. (Meldrum et al., 2013; Nel et al., 2007; Nguyen et al., 2019, Chapter 4). Simulating actual practices of routine disinfection in the field, the efficacy of these disinfectants significantly reduced when tested against chlamydospores that were embedded in the soil (Chapter 4). This is likely due to the fact that organic matter (soil) reduces the access of these disinfectants to chlamydospores (Ewart, 2001; Amass, 2001) rendering it less effective. On top of that, we observed disagreements between the required and observed disinfectant exposure time in quarantine baths under field conditions that will impede efficacy especially against chlamydospores embedded in soil (Chapter 4). This underscores the need for a "come clean - go clean" strategy to effectively use these disinfectants. We suggest that each farm - apart from the quarantine baths - implements a wash down facility to get rid of soil or other organic particles attached to vehicles, footwear or other farm implements. The removal of organic load comes first prior to soaking in quarantine baths. Since this is not implemented yet along with other factors, it is not surprising that - despite the implementation of biosecurity measures to decontaminate tools, footwear, vehicles or any other farm implements, the disease has not stopped spreading. Thus, taken together, the current situation is grim, particularly since the divide between large plantations where biosecurity measures are strictly implemented and surrounding small-scale farmers that cannot rigorously implement these measures is only expanding. Recurring traffic between 
these farms and exchange of personnel further complicate disease management (Chapter 3).

In the absence of new resistant cultivars that can replace susceptible varieties, eradicating the pathogen is an important way to mitigate the impact and future economic losses by reducing the availability of infectious propagules. Methods such as solarization (Butler et al., 2012c; Chellemi, 2002; Chellemi et al., 2002; Gamliel A and Katan, 2012; Yildiz et al., 2010; Vitale et al., 2011) and anaerobic soil disinfestation Japan (Butler et al., 2012a, 2012b; Lamers et al., 2004; Momma, 2008, Shennan et al., 2014) are efficacious and are also applicable in organic production and at small holder settings (Van Bruggen et al., 2015). Recently, the Israeli government claimed the successfully eradication of TR4 two years after its incursion (ProMusa, 2018). However, this seemed largely driven by politics as the eradication procedure was not disclosed. Indeed, in 2019 the disease was detected at several sites near the original infected locations (ProMusa, 2019). In Australia, the first incursion of TR4 in Northern Queensland - the heart of commercial banana cropping - prompted the complete removal (herbicide injection and treatment with urea) of banana plants of a surrounding 10 ha. block eventually followed by a farm buyout and complete cessation of banana cropping to halt the disease. This is impossible in the Philippines, especially for small-scale farmers who depend only on their farms (usually $\leq 1 \mathrm{ha}$ ) for a living. Instead, they practice single plant eradication by burning using either rice hull or wood even though the efficacy is not supported with concrete experimental data. While soil sanitation is optimal in the top soil of up to $40 \mathrm{~cm}$ below the surface, it is not beyond (Chapter 3 ) where roots and biological processes are still active up to one meter depth (Araya et al.,1998). This can be a big disadvantage especially in the light of TR4 dispersal by root-to-root contact between plants (Dita et al., 2018) and given the fact that TR4 chlamydospores are still present and alive up to $1 \mathrm{~m}$ below the soil surface (Chapter 3 ). On top of that, this strategy also contributes to the loss of nutrient capital e.g. nitrogen, calcium, magnesium, organic matter and beneficial microorganisms (Neary et al., 1999; Hungerford et al., 1991) and only has a local effect as it insufficiently affects pathogen propagules in nearby untreated (un)infected plant (at least $1 \mathrm{~m}^{2}$ ). Moreover, the increasing demand of rice hull drives the price thereby making this eradication procedure very expensive (estimated at 20 US\$ per infected plant), useless and biologically and economically unsustainable. A harsh conclusion that should have been drawn at least a decade ago upon proper experimentation and data gathering (Chapter 3). We, therefore investigated a soil treatment method to generate anaerobic conditions (Chapter 5). Previously, inundation was practiced during the Gros Michel epidemic (Stover, 1954), and also has resulted in efficacious eradication of soil-borne pathogens (Van Os et al., 1999). However, water flooding also disseminates the Fusarium spp. inoculum if not appropriately managed. Anaerobic soil disinfestation (ASD) or microbiome reconstruction have been practiced for Panama disease control (Shen et al., 2019; Huang et al., 2015) along with other economically important soil-borne diseases in various crops (Butler et al., 2012a; Butler et al., 2012b; McCarty et al., 2012; Shennan et al., 2014 ). In our case we preferred to work with a commercial product that guarantees constant quality, which would result in a scalable technology that can be implemented across the banana sector, whether from an industrial nature or a small holder setting. The Herbie products indeed 
significantly reduced TR4 quantity both in artificially inoculated soil (high inoculum density) and in naturally infested soil (low inoculum density) which resulted in a slower recurrence of disease in the highly susceptible banana compared to the controls. That is an important observation, particularly in a time frame where agronomical solutions are not at hand (Chapter 5). All other observations (Chapters 2-4) underpin important gaps of knowledge, but ASD literally and curatively reduces risks and therefore contributes to effective disease management and continuation of production (Chapter 5 ). The small scale application that we piloted also guarantees that the method can be implemented at small farms and can be applied irrespective of the banana varieties that are cropped. From an epidemiological standpoint (Chapters 3 and 5) reduction of inoculum is a straight forward approach, which is perpendicular on the strategy to grow less susceptible or partially resistant Giant Cavendish Tissue Culture Variants or GCTCV clones (Hwang et al., 2004; Molina et al., 2016). The massive promotion of these clones (Banana Asia Pacific Network, 2016; Agriculture Magazine, 2014; Philippine News Agency, 2018) as the solution for Panama disease in Cavendish is a hoax as basic epidemiological insight (Vander Plank, 1963; Zadoks and Schein, 1979) informs us that partial resistance only reduces the rate of an epidemic. For annual crops and foliar diseases this concept has worked very well in disease management, but for a soil-borne disease in a perennial crop, it would be just a matter of time until the epidemiologically critical levels are reached. This consideration seems to be exemplified in nearly all areas where somaclones have been planted in an attempt to manage TR4, whether in China, Mozambique or the Philippines. Hence, the long term and sustainable solution for Panama disease seems the development and introduction of varieties that have a level of resistance which enables economically feasible production even when planted in infested soils. The ultimate examples are the Cavendish clones that are cropped for decades around the world on Fusarium spp. race 1 infested soils. A technological proof of concept was recently delivered by developing genetically modified Cavendish clones that survived in TR4 infested soils in Australia (Dale et al., 2017).

\section{Science application for a diverse audience}

The current thesis has delivered critical data that underpin broadly implemented strategies to manage Panama disease in Mindanao and elsewhere. Practical lessons that we have learned revolve around enabled rapid diagnosis in the field, maintenance of inoculum in plantations either in the soil but also on the survival of TR4 in weeds, reduced efficacy of disinfectants and potential reduction of inoculum as a result of ASD. To improve disease management a few recommendations have emerged from this thesis that apply to different stakeholders in the banana chain.

Growers should make themselves and their personnel fully acquainted with the symptoms of Panama disease to avoid confusion with other disease, such as the bacterial diseases Erwinia blight or Moko. Furthermore, they should have access to diagnostic services either through the government of through the companies Tadeco (Davao del Norte) and Unifrutti ( Bukidnon) that have fully operational laboratories equipped for TR4 diagnosis. 
Furthermore, they should restrict traffic across their plantations and ensure full awareness of their employees in the danger of TR4 dissemination. Logistics in and around the farm has to be reduced and cleaning devices have to be built to assure the removal of infested soil from tires and other parts of vehicles. This is an investment, but will render vehicles clean and will also maintain the efficacy of disinfectants in any disinfectant dipping station as soil contamination reduces it (Chapter 5). The overall attitude in the sector should facilitate the exchange of best practices. One grower excelling and the other succumbing does not help the industry in Mindanao. Furthermore, extension officers and consultants have to be updated on the latest scientific progress and results and I recommend developing an overarching industry-wide TR4 hotline - and back office - that enables the dissemination of scientifically grounded advice.

Consumers are essentially unaware of the fragility of global banana production and should be communicated properly on the unsustainable production system. Community driven change is not impossible as is also shown by the opposition towards intensive animal husbandry. Albeit that plant life might be regarded dissimilar from animal welfare, the manifold workers and families depending on the banana trade brings in a societal component that warrants much more attention in newspapers and popular journals. Wageningen University has done a great job to inform innocent consumers on global banana production and its challenges and should pursue and internationalize that strategy.

Governments do frequently consider the Panama disease epidemic to be an industry problem. This attitude ignores the fact that many local banana varieties are equally susceptible and prone to destruction, which affects local markets and livelihoods. Hence, it is required that alliances between banana production stakeholders, irrespective of their size, and governments will be developed to ensure efficient exchange of information as well as the adoption of regulations to prevent new incursions of TR4. The Philippine Banana Growers and Exporters Association is one of these industry wide agencies that could immensely benefit from access to the latest sound information on TR4 occurrence and control. Although stronger links with governmental agencies is recommended, it should be reluctant for policy involvement by truly prioritizing the needs of the industry and the reliability of adopted recommendations. This can only be guaranteed by joint investigations and sound data analyses as a foundation for industry wide advice.

Taken together, this thesis has delivered a wealth of information on the practical impact of the TR4 epidemic in Mindanao. Despite, its value, we also have to conclude that these data will not result in a final control of TR4, particularly since it also ravages banana plantations with local varieties. However, a few practical highlights should be underscored. Accurate diagnosis is the cornerstone of disease management and should use the latest technologies that can detect TR4 in non-symptomatic plants and weeds. Consequently, weed management is an essential component of disease management. ASD does reduce TR4 inoculum in soil and is scalable, thereby supporting a multitude of stakeholders. However, semi-commercial trials need to be conducted before it can be recommended as an overall strategy. It is from that perspective, a significant draw-back that national bureaucracy can slow down permit 
acquisition for several years, which does not support a desperate industry that is among the top-exporters of the world and of economic significance for the country. Finally, adoption of a mandatory "come clean - go clean" practice will eventually support all growers and increase the efficacy of biosecurity measures.

Finally, I would like to underscore the need for continued research. The current data lifted the tip of the veil for practical considerations of Panama disease management. However, we should not forget - and many stakeholders do - that genetics, host resistance is a cornerstone of effective disease management. Cavendish bananas saved the industry. Yet, we do not understand why. Not a single gene responsible for its natural resistance to Fusarium spp. race 1 strains has been identified and thus the underlying mechanisms of its durable resistance are not understood. Once that is known, we can develop a suite of new diverse varieties for both industrial and small-holder settings. The recent World Food Price award to the founders of East-West plant breeders, https://www.worldfoodprize.org, is therefore a genuine recognition of the contribution of plant breeding to human welfare. Provided the importance of banana as a staple for millions of people, I cannot sufficiently underscore, and I have history at my side, that future research should focus on everything that is required to provide growers with healthy seed.

At the end of the day, we want science to work for us and not only in papers. The farmers or the banana industry in general desperately look for solution(s) that are reproducible, cost-efficient and long-lasting. In a perfect world, we want an absolute solution, enabling continued banana production at reduced costs. This benefit comes after the spending. Research and development to manage Panama disease is not an overnight job and needs time, resources, concerted action and an industry-wide responsibility to achieve the desired result. As adequately resistant banana varieties are not yet at hand, the integration of different short to medium-term disease management strategies (Chapter 3, 4, 5) should be implemented while investing in long-term solutions that should be spearheaded by developing new varieties. All these efforts should be backed by governmental policies and regulations. This will eventually result in more efficient, sustainable and economically viable disease management strategies. 


\section{References}

Anonymous (2015) Accessed at http://www.freshfruitportal.com/news/2015/11/02/tr4-infectionspreads-on-mozambique-banana-plantation/?country=southafrica.

Aguayo J, Mostert D, Fourrier-Jeandel C, Cerf-Wendling I, Hostachy B, Viljoen A, et al. (2017) Development of a hydrolysis probe-based real-time assay for the detection of tropical strains of Fusarium oxysporum f. sp. cubense race 4. PLoS One 12(2).

Almeida, R. P.P. (2016) Can Apulia's olive trees be saved? Science (22): 346-348.

Amass, S.F., B.D. Vyverberg, C.A. Dowell, C.D. Anderson, J.H. Stover, and D.J. Beaudry. (2000) Evaluating the efficacy of boot baths in biosecurity protocols. Swine health and production 8(4):169-173.

Araya M.,Vargas, A. Cheves, A. (1998) Changes in distribution of roots of banana (Musa AAA cv. Valery) with plant height, distance from the pseudostem, and soil depth. Journal of Horticultural Science and Biotechnology 73:437-440.

Aurore, G., Parfait, B. and Fahrasmane, L. 2009. Bananas, raw materials for making processed food products. Trends in Food Science \& Technology 20: 78-91.

Baker, R. (1978) Inoculum potential. In: Horsfall J.G. and Cowling E.B. (eds) Plant disease 1: How disease is managed. Academic NY 137-157.

Banihashemi, Z. and deZeeuw, D.J. (1975) The Behavior of Fusarium oxysporum f.sp. melonis in the presence and absence of host plants. Phytopathology 65:1212-1217.

Bebber, D.P., Holmes, T., Smith, D., \& Gurr, S J. (2014). Economic and physical determinants of the global distributions of crop pests and pathogens. New Phytopalogist 202(3), 901-910.

Blomme, G., Dita, M., Jacobsen, K.S., Pérez Vicente, L., Molina, A., Ocimati, W., . . Prior, P. (2017). Bacterial diseases of bananas and Enset: Current state of knowledge and integrated approaches toward sustainable management. Frontiers in Plant Science 8(1290): 1-25.

Blomme, G., Dita, M., Jacobsen, K.S., Vicente, L.P., Molina, A., Ocimati, W., Poussier, S., Prior, P. (2017) Bacterial Diseases of Bananas and Enset: Current State of Knowledge and Integrated Approaches Toward Sustainable Management. Frontiers in Plant Science 8: 1290.

Buddenhagen I. W. (1994). "Banana diseases caused by bacteria," in Compendium of Tropical Fruit Diseases eds Ploetz R. C., Zentmyer G. A., Nishijima W. T., Rohrbach K. G., Ohr H. D., editors. (St. Paul, Minnesota: APS Press) 15-17.

Burdon, J.J and Thrall, P.H. (2007) Pathogen evolution across the agro-ecological interface: implications for disease management. Blackwell Publishing 1:57-65.

Butler, D. (2013). Fungus threatens top banana. Nature 504: 195-196.

Chellemi, D.O., Gamliel, A., Katan, J. and Subbarao, K.V. (2016) Development and deployment of system-based approaches for the management of soilborne plant pathogens. Phytopathology 106: 216-225.

Chittarath, K., Mostert, D., Crew, K. S., Viljoen, A., Kong, G., Molina, G., \& Thomas, J. E. (2017). First report of Fusarium oxysporum f.sp. cubense tropical race 4 (VCG 01213/16) associated with Cavendish bananas in Laos. Plant Disease 449.

Corine N., Schoebel, Stewart, J., Niklaus, J., Gruenwald, Rigling, D., Prospero, S. (2014) Population history and pathways of spread of the plant pathogen Phytophthora plurivora. PLoS One 9(1).

Dale, J., James, A., Paul, J.Y., Khanna, H., Smith, M., Peraza-Echeverria, S., Garcia-Bastidas, F., Kema, G., Waterhouse, P., Mengersen, K. and Harding, R. (2017) Transgenic Cavendish bananas with 
resistance to Fusarium wilt tropical race 4. Nature communications 8(1):1496.

Davidson, J.M., Wickland, A.C., Patterson, H.A., Falk, K.R. and Rizzo, D.M. (2005) Transmission of Phytophthora ramorum in mixed-evegreen forest in California. Phytopathology 95:587-596.

Dita, M., Barquero, M., Heck, D., Mizubuti, E.S.G. and Staver, C.P. (2018) Fusarium Wilt of Banana: Current Knowledge on Epidemiology and Research Needs Toward Sustainable Disease Management. Frontiers in Plant Science 9:1468.

Dita, M.A., Waalwijk, C., Buddenhagen, I.W., Souza Jr, M.T., \& Kema, G.H.J. (2010). A molecular diagnostic for tropical race 4 of the banana Fusarium wilt pathogen. Plant Pathology 59(2): 348357.

Ewart, S.L (2001) Disinfectants and control of environmental contamination. In Smith B.L (ed.) Large animal internal medicine: diseases of horses, cattle, sheep and goats. $3^{\text {rd }}$ ed. St. Louis: Mosby. pp1371-1380.

FAOSTAT. Food and Agricultural Organization of the United Nations Statistical Databases, Production Statistics, Crop-Banana, World production. Available at http://faostat.fao.org/

Fisher, M.C., Henk, D.A., Briggs, C.J., Brownstein, J.S., Madoff, L.C., McCraw, S.L. and Gurr, S.J. (2012) Emerging fungal threats to animal, plant and ecosystem health. Nature 484:186-194.

García, F., Ordóñez, N., Konkol, J., Al-Qasim, M., Naser, Z., Abdelwali, M., . . Kema, G.H.J. (2014). First report of Fusarium oxysporum f.sp. cubense tropical race 4 associated with Panama disease of banana outside Southeast Asia. Plant Diease 98(5): 694.

Garcia, F.A., Bakry, F., Irish, B.M. and Kema, G.H.J. (2019) Resistance in banana to Fusarium spp. causing Panama disease: Triploid, Diploid and Hybrid accessions. PhD thesis, Wageningen University and Research, Wageningen, The Netherlands.

Georgios Skiadaresis, G., Schwarz, J. A. and Bauhus,J. (2019) Groundwater Extraction in Floodplain Forests Reduces Radial Growth and Increases Summer Drought Sensitivity of Pedunculate Oak Trees (Quercus robur L.) Frontiers in Forests and Global Change 2(5).

Gilligan, C.A. (1994) Temporal aspects of the development of root disease epidemics. In: Campbell C.L. and Benson D.M. (eds) Epidemiology and management of root diseases. Springer Berlin 148-194.

Golan, J.J. and Pringle, A. (2017) Long-distance dispersal of fungi. Microbiology Spectrum American Society for Microbiology Press.

Hennessy, C., Walduck, G., Daly, A. and Podovan, A. (2005) Weed hosts of Fusarium oxysporum f.sp. cubense tropical race 4 in Northern Australia. Australasian Plant Pathology 34:115-117.

Huang, A.C., Jiang, T., Liu-Y-X., Bai, Y-C., Reed, J., Qu, B., Goossens, A., Nutzmann, H-W., Bai, Y., Osbourn, A. (2019) A specialized metabolic network selectively modulates Arabidopsis root microbiota. Science 364 (6440)

Hung, T. N., Hung, N. Q., Mostert, D., Viljoen, A., Chao, C. P., \& Molina, G. (2017). First report of Fusarium wilt on Cavendish bananas, caused by Fusarium oxysporum f.sp. cubense tropical race 4 (VCG 01213/16), in Vietnam. Plant Disease 448.

Hungerford, R.D., Harrington, M.G., Frandsen, W.H. Ryan, K.C., and Niehoff, G.J. (1991) Influence of fire on factors that affect site productivity. In 'Proceedings - Management and productivity of western-montane forest soils', AC Harvey (ed). Pp32-50. USDA Forest Service Intermountain Research Station General Technical Report INT-280.

Hwang, S.C. and Ko, W.H. (2004) Cavendish banana cultivars resistant to Fusarium wilt acquired through somaclonal variation in Taiwan. The American Phytopathological Society 88:580-588.

Katan, J. (2000) Physical and cultural methods for the management of soil-borne pathogens. Crop 
Prot., 19:725-731.

Katan, J. (2017) Diseases caused by soilborne pathogens: biology, management and challenges. Journal of Plant Pathology 99(2) 305-315.

Koike, S.T. and Gordon, T.R. (2015) Management of Fusarium wilt of strawberry. Crop Protection 73: 67-72.

Leslie, J.F., \& Summerell, B. (2006). The Fusarium Laboratory Manual: Blackwell Publishing.

Li, B., Du, J., Lan, C., Liu, P., Weng, Q., and Chen, Q. (2013) Development of a loop-mediated isothermal amplification assay for rapid and sensitive detection of Fusarium oxysporum f. sp. cubense race 4 European Journal of Plant Pathology 135:903-911.

Li, C.Y., Mostert, G., Zuo, C.W., Beukes, I., Yang, Q.S., Sheng, O., . . Y Yi, G.J. (2013). Diversity and distribution of the banana wilt pathogen Fusarium oxysporum f.sp. cubense in China. Fungal Genome Biology 3(2): 1-6.

Li, C.Y., Mostert, G., Zuo, C.W., Beukes, I., Yang, Q.S., Sheng, O., . . Y Yi, G.J. (2013b). Diversity and distribution of the banana wilt pathogen Fusarium oxysporum f.sp. cubense in China. Fungal Genome Biology 3(2): 1-6.

Lin, Y.H, Lin, Y.J., Chang, T.D., Hong, L.L., Chen, T.Y., and Chang, P.F.L. (2016) Development of a TaqMan probe-based insulated isothermal polymerase chain reaction (iiPCR) assay for detection of Fusarium oxysporum f. sp. cubense race 4. PLoS One 11:e0159681.

Lin, Y.H., Su, C.C., Chao, C.P., Chen, C.Y., Chang, C.J., Huang, J.W., and Chang, P.F.L. 2013. A molecular diagnosis method using real-time PCR for quantification and detection of Fusarium oxysporum $\mathrm{f}$. sp. cubense race 4. European Journal Plant Pathology 135:395-405.

Marquardt, S. (2001) "Green Havoc": Panama disease, Environmental Change and Labor Process in the Central American Banana Industry. The American historical review 106 (1): 49-80.

Maryani, N., Lombard, L., Poerba, Y.S., Subandiyah, S., Crous, P.W. and Kema, G.H.J. (2019) Phylogeny and genetic diversity of the banana Fusarium wilt pathogen Fusarium oxysporum f.sp. cubense in the Indonesian centre of origin. Studies in Mycology 92:155-194.

Meldrum, R.A., Daly, A.M., Tran-Nguyen, L.T.T., Aitken, E.A.B. (2013) The effect of surface sterilants on spore germination of Fusarium oxysporum f.sp. cubense tropical race 4. Crop Protection 54:194198.

Molina, A.B., Fabregar, E., Sinohin, V.G., Yi, G., and Viljoen, A. (2009) Recent occurrence of Fusarium oxysporum f.sp. cubense tropical Race 4 in Asia. Acta Horticulturae 828:109-115.

Mostert, D., Molina, A.B., Daniells, J., Fourie, G., Hermanto, C., Chao, C., Fabregar, E., Sinohin, V.G., Masdek, N., Thangavelu, R., Li, C., Yi, G., Mostert, L., and Viljoen, A. (2017) The distribution and host range of the banana Fusarium wilt fungus, Fusarium oxysporum f.sp. cubense, in Asia. PLoS One 12(7).

Neary, D.G., Klopatek, C.C., DeBano, L.F., Ffolliott, P.F. (1999) Fire effects on below ground sustainability: a review and synthesis. Forest Ecology and Management 122:51-71.

$\mathrm{Nel}$, B., Steinberg, C., Labuschagne, N., Viljoen, A. (2007) Evaluation of fungicides and sterilants for potential application in the management of Fusarium wilt of banana. Crop Protection 26: 697705.

Nguyen, T.V., Tran-Nguyen, L.T.T., Wright, C.L. Trevorrow, P. and Grice. K. (2019) Evaluation of the Efficacy of Commercial Disinfectants Against Fusarium oxysporum f. sp. cubense Race 1 and Tropical Race 4 Propagules.

Oerke, E.C. (2006) Crop losses to pests. Journal of Agricultural Science 144:31-43. 
Ordoñez N., Seidl M.F., Waalwijk C., Drenth A., Kilian A., Thomma B.P.H.J., et al. (2015) Worse Comes to Worst: Bananas and Panama Disease-When Plant and Pathogen Clones Meet. PLoS Pathogen 11(11).

Ordóñez, N., García-Bastidas, F., Laghari, H. B., Akkary, M. Y., Harfouche, E. N., al Awar, B. N., \& Kema, G. H. J. (2016). First report of Fusarium oxysporum f.sp. cubense tropical race 4 causing Panama disease in Cavendish bananas in Pakistan and Lebanon. Plant Disease 100(1):209.

Palmero, D., Iglesias, C., de Cara, M., Santos, L., Tello, J.C. (2009) Species of Fusarium Isolated from River and Sea Water of Southeastern Spain and Pathogenicity on Four Plant Species. Plant Disease 93: 377-385.

Peng J., Zhang, H., Chen, F., Zhang, X., Xie, Y., Hou, X., Li, G., and Pu, J. (2014) Rapid and quantitative detection of Fusarium oxysporum f. sp. cubense race 4 in soil by real-time fluorescence loopmediated isothermal amplification. Journal of Applied Microbiology 117:1740-1749.

Ploetz, R. C. (2015a) Management of Fusarium wilt of banana: A review with special reference to tropical race 4. Crop Protection 73:7-15.

Ploetz, R., Freeman, S., Konkol, J., Al-bed, A., Naser, Z., Shalan, K., Barakat, R., and Israeli, Y. (2015b) Tropical race 4 of Panama disease in the Middle East. Phytoparasitica 43:283-293.

Ploetz, R.C. (2000) Panama disease: a classic and destructive disease of banana. In: Plant Health Progress.

Ploetz, R.C. (2006) Fusarium wilt of banana is caused by several pathogens referred to as Fusarium oxysporum f.sp. cubense. The American Phytopathological Society 96:653-656.

Ploetz, R.C. (2008) Tropical race 4 of Panama Disease: A Dangerous Threat to Sustainable Production of Banana and Plantain. Caribbean Food Crops Society, Miami.

Ploetz, R.C. (2015). Management of Fusarium wilt of banana: a review with special reference to tropical race 4. Crop Protection 73: 7-15.

Ploetz, R.C., Thomas, J.E. and Slabaugh, W.R. (2003) Diseases of banana and plantains. In: Ploetz, R.C (ed.) CAB International. Diseases of Tropical Fruit Crops.

ProMusa (2018) Accessed at http://www.promusa.org/blogpost556-NPPO-declares-TR4-eradicatedfrom-Israel

ProMusa (2018) Accessed at http://www.promusa.org/blogpost580-TR4-present-in-the-UK

ProMusa (2019) Accessed at http://www.promusa.org/blogpost607-Update-on-TR4-in-Israel

Raaijmakers, J.M., Paulitz, T.C., Steinberg, C., Alabouvette, C. and Moenne-Loccoz, Y. (2009) The rhizosphere: a playground and battlefield for soilborne pathogens and beneficial microorganisms. Plant Soil 321:341-361.

Rillo A. R. (1979). Bacterial wilt of banana in the Philippines. FAO Plant Protection Bulletin 27:105-108. Schoebel, C.N., Stewart, J., Gruenwald, N.J., Rigling, D. and Prospero, S. (2014) Population history and pathways of spread of the plant pathogen Phytophthora plurivora. PLos One 9 (8).

Soluri, J. (2002). Accounting for taste: Exportbananas, mass markets, and Panama disease. Environmental History 7( 3), 386- 410.

Stover, R.H. (1962) Fusarial wilt (Panama disease) of bananas and other Musa species. Kew, UK: Commonwealth Mycological Institute.

Su, H.J., Hwang,S.C., Ko, W.H. (1986) Fusarial wilt of Cavendish bananas in Taiwan. Plant Disease 70:814-818

Thangavelu, R., Mostert, D., Gopi, M., Ganga Devi, P., Padmanaban, B., Molina, A.B. and Viljoen, A. 
(2019) First detection of Fusarium oxysporum f. sp. cubense tropical race 4 (TR4) on Cavendish banana in India. European Journal of Plant Pathology.

Valmayor, R.V., Jamaluddin, S.H., Silayoi, B., Kusumo, S., Danh, L.D., Pascua, O.C., and Espino, R.R.C. (2000) Banana cultivar names and synonyms in Southeast Asia. International Network for the Improvement of Banana and Plantain-Asia and the Pacific Office, Los Banos, Laguna, Philippines.

Waite, B.H. and Dunlap, V.C. (1953) Preliminary host range studies with Fusarium oxysporum f.sp. cubense. Plant Disease 37:79-80.

Warman, N.M. and Aitken, E.A.B. (2018) The movement of Fusarium oxysporum f.sp. cubense (subtropical race 4) in susceptible cultivars of banana. Frontiers in Plant Science 9(1748).

Wellings C.R. (2007) Puccinia striiformis in Australia: A review of the incursion, evolution and adaptation of stripe rust in the period 1979-2006. Australian Journal of Agricultural Research 58: 567-575.

Xu, L.B., Huang, B.Z. and Wei, Y.R. (2003) Production and banana R and D in China. In: Advancing banana and plantain R and D in Asia and the Pacific. A.B. Molina, J.E. Eusebio, V. N. Roa, I. van den Bergh and M.A.G.Maghuyop (eds) Los Banos INIBAP 77-80.

Yang, L.Sun, L., Ruan, X., Qiu, D., Chen, D., Cai, X., and Li, H. (2015) Development of a single-tube duplex real-time fluorescence method for the rapid quantitative detection of Fusarium oxysporum $\mathrm{f}$. sp. cubense race 1 (FOC1) and race 4 (FOC4) using TaqMan probes. Crop Protection 68: 27-35.

Zhang, X., Zhang, H., Pu, J., Qi, Y., Yu, Q., Xie, Y., and Peng, J. 2013. Development of a real-time fluorescence loop-mediated isothermal amplification assay for rapid and quantitative detection of Fusarium oxysporum f. sp. cubense tropical race 4 in soil. PLoS One 8.

Zheng, SJ., Garcia-Bastidas, F., Li, X., Zeng, L., Bai, T., Xu, S., Li, H., Fu, G., Yu, Y., Yang, L., Nguyen, HC., Dounneuang, D., Khaing, A., Drenth, A., Seidl, M., Meijer, H.J.G., and Kema, G.H.J. (2018) New Geographical Insights of the Latest Expansion of Fusarium oxysporum f.sp. cubense Tropical Race 4 Into the Greater Mekong Subregion. Frontiers in Plant Science. 
SUMMARIES 


\section{Summary}

Banana either cooking or dessert type is regarded as one of the most important crops being staple food or cash crop. Currently the global banana production is threatened by a destructive soil-borne fungus Fusarium odoratissimum colloquially called Tropical race 4 (TR4) causing Panama disease in banana. The on-going dispersal of the pathogen raises the fear of the demise of our beloved banana. As of this writing, there is no concrete solution available to combat the disease, hence manifold of management strategies are explored. With the use of molecular diagnostic tools, this thesis describes the spatial dispersal, epidemiology and management options of Panama disease in the banana belt of the Philippines. This contributes to the development of evidence-based and cost-effective management strategies.

In Chapter 1 the subject is presented by unfolding the biology of banana, brief history of its origin, distribution and its cultivation as a staple and cash crop. Having limited genetic variation, the vulnerability of banana to various diseases is described. Panama disease causing serious devastation in banana is elaborated with emphasis on its disease development, spatial and temporal dispersal, disease diagnostics employed and management strategies explored. Statement of the scope of the thesis and outline of the different chapters concluded this chapter.

Chapter 2 describes the development of DNA-based diagnostic tool for TR4. In here, a rapid and highly specific detection assay based on Loop Mediated Isothermal Amplification (LAMP) was developed that is pertinent under laboratory and field conditions. The TR4-specific DNA sequence was obtained by Diversity Arrays Technology sequencing of representative genetic diversity of Foc. The specificity of the assay was tested extensively on both target and nontarget isolates and successfully used to detect TR4 in artificially inoculated and naturally infected Cavendish banana corm and pseudostem in the Philippines. Hence, the developed assay offers a powerful tool for epidemiological study on TR4 and is indispensable for implementing quarantine measures.

Chapter 3 uncovers the unknown epidemiological phenomena of TR4 dissemination in the banana belt of the Philippines and validate the efficacy of applied management strategy. In here, the spatial distribution of TR4 across soil profiles cropped with either Cavendish or local banana cultivars reveals that the pathogen is distributed across soil layers of up to $1 \mathrm{~m}$ below. The dissemination through contaminated soil and water is presented suggesting the importance of deploying biosecurity measures. In the absence of banana host, the long term survival of TR4 on weeds was confirmed emphasizing the importance of weed management in combating Panama disease. Data supporting the efficacy of field sanitation by burning was presented revealing the inefficiency of the procedure to eliminate TR4 propagule in the soil and should be reconsidered. Together, this findings emphasize the need for an integrated and evidence-based Panama disease management strategies. 
Chapter 4 put emphasis on the efficacy of disinfectants used as front-line defense against TR4 spread in the banana production areas in the Philippines. In this study, disinfectants of different active ingredients, rate and exposure time were tested in vitro against different propagules of TR4 to include mycelia, conidiospores, chlamydospores suspensions and chlamydospores-infested soil. The TR4 mycelia and conidia are sensitive to disinfectants tested at the manufacturer's recommended concentration. The thick-walled chlamydospores were remarkably sensitive to disinfectants in suspension but the same compounds were largely ineffective against chlamydospores in soil except for diamidine-based disinfectant. Summing up, the rational choice of appropriate disinfectants should be facilitated by reliable data on efficacy under various biological, environmental and temporal conditions, corrosiveness and costs. The utilization of disinfectants should be maximized and properly implemented to stop or slow down TR4 dissemination within and between farms at local, regional or international scale.

Chapter 5 investigates the potential of anaerobic soil disinfestation (ASD) as a biological option for Panama disease management. In this study, two commercially available organic amendments were tested both under laboratory and field conditions in the naturally infested soils in the Philippines. Controlled condition in the laboratory resulted to reduction of viable TR4 chlamydospores to $0.01 \%$ in plastic containers after four weeks treatment supported by the production of toxic gases and volatile fatty acids. The pilot field experimentation displayed a hundred-fold reduction of TR4 chlamydospores level relative to the control after eight weeks field treatment. A significant reduction of Panama disease recurrence was recorded on replanted Cavendish "Williams" banana monitored for one cropping cycle. These promising results might contribute to short-term management options to continue banana production in Panama disease affected farms.

Chapter 6 summarizes the findings gathered in this PhD project. The continued local and international TR4 dispersal is discussed in relation to containment strategies and management options currently employed. The importance of the molecular diagnostic tool to chart progression of disease spread is discussed. The systematic approach to manage soil-borne pathogens are reviewed linking to the current practices to continue banana production despite the presence of TR4. The pathogen inoculum density and disease incidence curve was correlated to the current knowledge. This gives rise to the statement that partial resistance to Panama disease does not ultimately contributes to sustainable disease control. The intended long-term perspective for banana growing lies in an integrated management strategy that includes the use of multiple resistant banana varieties. 


\section{Samenvatting}

Bananen, of het nu kook of dessert types betreft, worden in het algemeen beschouwd als een belangrijk onderdeel van de primaire voedsel- of handelsgewassen. Momenteel wordt de wereldwijde bananenproductie bedreigd door de destructieve bodemschimmel Fusarium odoratissimum, in de volksmond "Tropical Race 4" (TR4) genoemd, die Panamaziekte in bananen veroorzaakt. De huidige verspreiding van dit pathogeen roept de vrees op voor de ondergang van de geliefde banaan. Tot op heden is er geen concrete oplossing om Panamaziekte te beheersen en daarom worden er allerlei managementstrategieën geopperd en onderzocht. In dit proefschrift worden de ruimtelijke verspreiding en de epidemiologie van Panamaziekte beschreven door gebruik te maken van moleculaire diagnostica in de context van de huidige praktijken in de Filipijnse bananengordel. Daarmee draagt dit proefschrift bij aan de ontwikkeling van een kostenbewuste en op data gebaseerde managementstrategie.

In Hoofdstuk 1 wordt het onderwerp gepresenteerd door het ontvouwen van de biologie en een korte geschiedenis van de herkomst, verspreiding en de teelt van de banaan als voedsel- en handelsgewas. De beperkte genetische diversiteit die leidt tot de kwetsbaarheid van de banaan voor verschillende ziekten wordt beschreven, met name ten aanzien van Panamaziekte. De ziekteontwikkeling, ruimtelijke en historische verspreiding, gebruikte ziekteherkenningsmethodieken en beheersingsstrategieën worden beschreven. Het hoofdstuk sluit af met diverse hypothesen en een overzicht van de inhoud van het proefschrift.

Hoofdstuk 2 beschrijft de ontwikkeling van een nieuwe, op DNA gebaseerde methode om TR4 aan te tonen. De snelle en zeer specifieke detectiemethode is gebaseerd op Loop Mediated Isothermal Amplification (LAMP) en is zowel in het laboratorium als het veld te gebruiken. TR4-specifieke DNA-sequenties werden verkregen door een representatieve collectie van Fusarium soorten die geassocieerd zijn met Panamaziekte te analyseren met een hoge resolutie genotyperingsmethode die is gebaseerd op Diversity Arrays Technology. Vanaf het moment dat een specifieke sequentie werd bepaald, is de methode gevalideerd op vele soorten schimmels om daarna succesvol gebruikt te worden om TR4 aan te tonen in geïnoculeerde en natuurlijk besmette Cavendish planten in de Filippijnen. De ontwikkelde methode is daarom een krachtig gereedschap om de epidemiologie van TR4 te onderzoeken en is daarmee onmisbaar voor de implementatie van quarantainemaatregelen.

Hoofdstuk 3 beschrijft de ontdekking van onbekende epidemiologische feiten met betrekking tot de verspreiding van TR4 in de Filipijnse bananengordel en valideert daarmee de effectiviteit van toegepaste beheersingsstrategieën. De ruimtelijk verdeling van TR4 door het profiel van bodems waarin Cavendish of lokale bananenvariëteiten worden geteeld laat zien dat het pathogeen tot zeker 1 meter onder de grond voorkomt. De verspreiding door gecontamineerde grond en besmet water is vastgesteld, hetgeen het belang van quarantainemaatregelen onderstreept. De lange-termijn overleving van TR4 in onkruiden tijdens de afwezigheid van waardplanten werd bevestigd waarmee het belang 
van onkruidbeheersing om Panamaziekte te beheersen werd benadrukt. Verder werden er data verzameld om na te gaan wat de effectiviteit is van diverse beheersingsstrategieën, waaronder het verbranden van het kaf van rijst. Dit bleek inefficiënt om TR4 uit de grond te verwijderen en moet daarom heroverwogen worden. Tezamen onderstrepen deze gegevens de noodzaak van een geïntegreerde en empirische beheersingsstrategie voor Panamaziekte.

Hoofdstuk 4 gaat in op de effectiviteit van desinfecterende middelen die worden gebruikt als eerstelijns verweer tegen de verspreiding van TR4 in de bananen-producerende gebieden van de Filipijnen. In dit onderzoek werden verschillende desinfecterende middelen met diverse actieve ingrediënten getest onder in vitro condities in uiteenlopende concentraties en blootstellingstijden op mycelium, conidiosporen, chlamydosporen in suspensie en in grond. Alle desinfecterende middelen zijn effectief in de door de producenten aanbevolen concentraties, zelfs voor de dikwandige chlamydosporen. Zodra deze echter in grondmonsters werden getest was alleen een op diamide gebaseerd desinfecterend middel effectief. Samengenomen is de les dat de juiste desinfecterende middelen alleen kunnen worden ingezet na een zorgvuldige analyse van hun effectiviteit onder diverse condities, waarbij rekening wordt gehouden met biologische variatie, omgevingsfactoren, blootstellingsduur, de corrosie van diverse metalen en de te maken kosten. Het gebruik van desinfecterende middelen moet worden gemaximaliseerd en op de juiste wijze worden geïmplementeerd om de lokale, regionale en internationale verspreiding van TR4 te vertragen of te stoppen.

Hoofdstuk 5 beschrijft experimenten waarin werd onderzocht of anaerobe bodem desinfectie een biologische bestrijdingsoptie is voor Panamaziekte. In dit onderzoek werden twee commercieel beschikbare organische producten getest onder laboratoriumen veldomstandigheden in natuurlijk besmette bodems in de Filippijnen. In de laboratoriumexperimenten - gedurende vier weken onder gecontroleerde omstandigheden in plastic emmers - werd de hoeveelheid levende TR4 chlamydosporen gereduceerd tot $0.01 \%$ door een combinatie van toxische gassen en vluchtige vetzuren. De pilotexperimenten in het veld leverden ook een honderdvoudige reductie van TR4 inoculum op bij een behandeling van acht weken. Dit resulteerde in een sterk vertraagde terugkeer van Panamaziekte tijdens een volledige gewascyclus nadat deze behandelde veldjes weer werden beplant met het Cavendish ras "Williams". Deze bemoedigende resultaten kunnen bijdragen aan het ontwikkelen van korte-termijn opties om Panamaziekte te beheersen en de bananenteelt op besmette bedrijven te continueren.

Hoofdstuk 6 is een samenvatting van de resultaten die in dit PhD project werden behaald. De voortgaande lokale en internationale verspreiding van TR4 wordt besproken in relatie tot de huidige quarantainemaatregelen en managementstrategieën. Het belang van moleculaire diagnostica om de verspreiding van TR4 beter in kaart te brengen wordt besproken in de context van een systematische aanpak om bodemgebonden ziekten te beheersen. Daarbij wordt de voortzetting van de bananenteelt ondanks de aanwezigheid van TR4 afgezet tegen de huidige praktijken die daarmee worden geëvalueerd. Op basis van de verzamelde gegevens is een gewijzigde hypothese opgesteld ten aanzien van de hoeveelheid TR4 in de bodem en 
Summaries

de incidentie van Panamaziekte. Dit geeft aanleiding tot de stelling dat partiële resistentie tegen Panamaziekte uiteindelijke niet bijdraagt aan een duurzame ziektebeheersing. Het beoogde lange-termijn perspectief voor de bananenteelt is gelegen in een geïntegreerde managementstrategie waar het gebruik van meerdere resistente bananenrassen deel van uitmaakt. 


\section{Pagpalaktod}

Ang saging nga pangluto o panghimagas nga klase usa sa mga pinaka importanteng tanom tungod inila kini nga 'staple food ug cash crop'. Ang kasamtangang produksyon sa saging naapektuhan tungod sa pagkuyanap sa sakit nga anaa nagpuyo sa yuta, ang Fusarium odoratissimum o mas naila nga tropical race 4 (TR4) hinungdan sa Panama nga sakit sa saging. Ang pagdaghan sa nasaysay nga kagaw naghatag ug dakong kahadlok nga mapapas ang atong gikahimut-an nga saging. Kining panahuna sa akong pagsulat, walay konkretong solusyon sa pagsumpo niini, maong adunay daghang stratehiya ang gi-istudyuhan. Pinaagi sa paggamit sa 'molecular diagnostic tools', kining pag-istudyo agig thesis naghatag ug deskripsyon sa pagkatag-katag, pagtakod, ug managlahing pamaagi sa pagdumala sa Panama disease sa mga kasagingan sa Pilipinas. Kini magdugang sa kalamboan sa paghimo ug mga bag-ong istratehiya sa pagdumala sa maong sakit base sa nakuhang ebidensya ug adunay ekonomikanhong konsiderasyon.

Ang unang bahin, ang hilisgutan gipresentar ang 'biology' sa saging, mubo nga kasaysayan sa gigikanan niini, ang pagkatag-katag, ug pag-apod-apod ug pagpananom niini ingon nga usa ka pangunang pagkaon ug tinubdan sa kita. Tungod sa limitadong klase sa genetics niini, ang kahuyang sa saging sa lainlaing sakit gihulagway. Ginatuki niining dokumento ang dakong kadaot nga gihatag sa Panama disease, ang iyang dali ug dakong pagkatag, ang pag ila niini, ug ang mga istratehiya sa pagdumala niini. Ang gilangkuban niining thesis ug ang outline sa nagkalain laing bahin gipakita niining bahina.

Ang ikaduhang bahin naghisgot sa pagmugna sa DNA-based diagnostic nga himan alang sa TR4. Dinhi, usa ka pinadali nga pagdetik base sa Loop Mediated Isothermal Amplification (LAMP) ang naugmad nga may kalabotan sa laboratoryo ug mga kahimtang sa umahan. Nakuha ang TR4-specific DNA sequence pinaagi sa Diversity Arrays Technology nga gikan sa pag-sequence sa nagkalain laing klase sa Foc. Ang pagkaespisipiko sa assay gi testingan sa mga target ug dili target nga mga isolates ug malampuson nga gigamit sa pag-ila sa TR4 sa artipisyal ug natural nga natakdan nga Cavendish nga klase sa saging sa Pilipinas. Mao nga ang namugna nga assay naghatag ug usa ka maayong pamagi sa pag-istudyo sa pagkalap sa TR4 ug ang mga gikinahanglan sa pag implementar sa mga pamaagi sa kwarentina.

Ang ikatulong bahin nagbutyag sa mga wala pa mailhi ug talagsaong panghitabo sa epidemolohiya sa pagkatag sa TR4 sa mga kasagingan sa Pilipinas ug pagbalido sa pagkaepektibo sa mga gihimong istratehiya sa pagdumala niini. Diri mahibal-an ang pagkuyanap sa TR4 sa mga nagkalain laing pamaagi ug sa yuta hangtud sa usa ka metro nga tinamnan sa saging nga Cavendish ug lokal nga klase. Ang pagkaylap niini mahitungod sa mga kontaminadong yuta ug tubig nga nagpagsabot nga gikinahanglan ang pag-implementa ug 'biosecurity measures'. Kung walay saging nga taptanan sa sakit, nakompirma nga mabuhi ang TR4 sa mga sagbot nga nagpasabot sa importansya sa pagdumala sa sagbot aron masumpo ang Panama disease. Gi - presenta usab ang mga datos sa kalidad sa paglimpyo sa uma pinaagi sa pagsunog og nagpakita nga dili kini epektibong pamaagi sa pagwagtang 
sa TR4 sa yuta, busa kinahanglan kining istudyuhan. Gipakita niini nga mga kaplag ang panginahanglan alang sa usa ka hiniusa og datus na basehan sa pagdumala sa Panama disease.

Ang ikaupat nga bahin, nag-hatag ug importansya sa mga nagkalain laing kemikal para pang-disinpeksyon isip paunang depensa sa pagkuyanap sa sakit sa mga yutang gitamnan ug saging sa Pilipinas. Sa pag-istudyo, gi-testing ang mag nagkalain laing kemikal para pang disinpeksyon nga adunay lain laing aktibo nga sangkap, kadaghanon, ug panahon sa pagkaladlad pinaagi sa laboratoryo nga pag istudyo gamit ang lain laing klase sa TR4 sama sa mycelia, conidiospores, chlamydospores suspensyon ug chlamydospores sa mga nataptap nga yuta. Ang mycelia ug conidia sa TR4 sensitibo sa kemikal para pang disinpeksyon basi sa rekomendasyon sa kadaghanon sa mga naghimo niini. Ang baga'ng chlamydospores sa solusyon sensitibo sa mga kemikal para pang disinpeksyon apan dili epektibo sa chlamydospores nga anaa sa yuta pwera sa diamidine-based nga kemikal para pang disinpeksyon. Sa paglaktod, ang pagpili sa saktong disinfectant kinahanglan base sa mga kasaligan nga mga datos sa iyang ka epektibo sa nagkalain lain biyolohikal, kinaiyahanhong palibot ug temporaryong kondisyon, makadaot nga epekto ug gasto. Gikinahanlang masuyod ang paggamit ug sakto nga pag implementar niini aron mahunong o mohinay ang pagkuyanap sa TR4 sulod sa uma, sa mga kasigbit nga umahan, sa ubang lugar sulod ug gawas sa nasod.

Sa ikalimang bahin gina imbestigahan ang posilibidad sa paggamit sa anerobic soil disinfection (ASD) isip usa ka pamaagi'ng kinainyanhon sa pagsugpo sa Panama disease. Diri, duha ka organikong materyal ang gi-testingan sa laboratoryo ug sa uma sa mga yutang nataptan sa Pilipinas. Ang kontrolado nga kondisyon sa laboratoryo miresulta sa pagkunhod sa mabatbat nga TR4 chlamydospores ngadto sa $0.01 \%$ sa mga plastik nga sudlanan human sa upat ka semana nga pagtambal nga gisuportahan sa produksyon sa mga makahilo nga mga gas ug mga volatile fatty acids. Ang gibuhat nga paunang testing sa umahan nagpakita sa usa ka gatus ka pilo nga pagkunhod sa TR4 chlamydospores kalabot sa kontrol human sa walo ka mga semana og ang taas nga pagkunhob sa Panama disease sa mga tinanom nga Cavendiah "Williams" nga saging sulod sa usa kapanahon sa pagtanom. Kining malaumon nga resulta makatampo sa mga kapilian sa pagdumala aron magpadayon ang produksyon sa mga kasagingan nga naapektuhan sa Panama disease.

Ang ikaunom nga bahin, naglaktod sa mga resulta sa pagpanukiduki niining PhD project. Gisaysay ang pagpadayon nga pagkuyanap sa TR4 sa lokal ug internasyonal nga adunay kalambigitan sa istratehiya sa kasamtangang pagdumala niini. Gihisgutan usab ang importansya sa molecular diagnostic tool aron masubay ang pagkalap niini. Gi-rebyu usab niini ang sistematikong pamaagi sa kasamtangang pagdumala sa hinundang kagaw nga anaa sa yuta aron mapadayon ang produksyon sa saging bisan pa man ug adunay TR4. Ang kadaghanon sa kagaw ug ang kadaghanon sa mga kaso sa nataptan ug sakit adunay kalambigitan sa kasamtangang kahibalo. 
ABOUT THE AUTHOR 



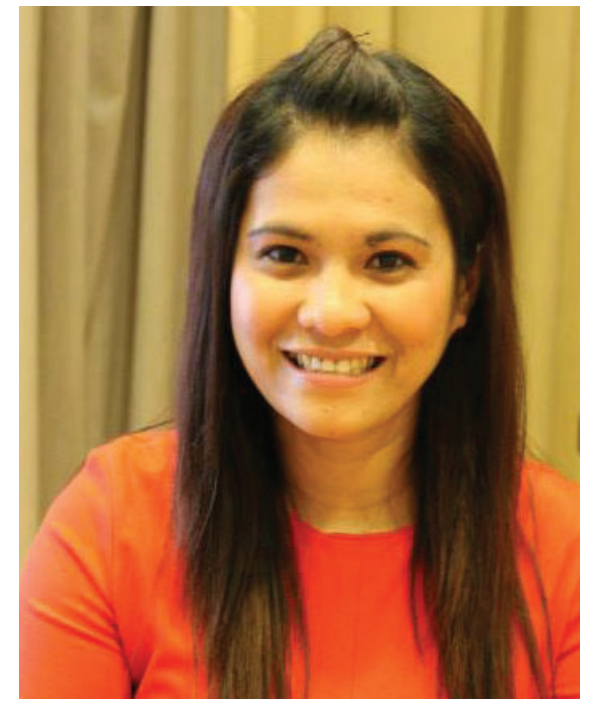

Maricar Salacinas-Niez was born on 22 June 1983 in Cagayan de Oro City, Philippines where she completed her primary and secondary education. In 2004 she finished her bachelor's degree in Biology with a major in Ecology at the University of the Philippines, Mindanao. She was a recipient of a Belgian VLIR-UOS scholarship and finished her master's degree in plant production with a major in molecular biology at the Katholieke Universiteit Leuven (KUL), Belgium in 2011. Her master thesis was conducted at the Laboratory of Tropical Crop Improvement of KUL and focused on the initial characterization of two candidate banana genes and their promoters that are expressed upon infections with the Black Sigatoka fungus Pseudocercospora fijiensis under the supervision of Dr. ir. Serge Remy and Prof. Dr. ir. Ronny Swennen. She then joined the faculty of Biological Sciences and Environmental Studies of the University of the Philippines, Mindanao, as assistant professor. In order to further her studies, she joined the group of Prof.dr.ir.ing. Gert Kema as PhD student in 2013 in the Interdisciplinary Research and Education Fund (INREF) program of Wageningen University. Her research project focused on understanding the dynamics of inoculum dispersal and survival and the epidemiology of Fusarium odoratissimum Tropical Race 4 (TR4) causing Panama disease in banana in the Philippines. During her PhD research, she worked in close collaboration with large banana companies in the Philippines, including Tadeco Inc., Unifrutti Tropical Philippines Inc. and NEH Philippines. In 2018 she was hired as research scientist at the Stanfilco division of Dole Philippines Inc. to manage banana vascular diseases (Moko and Panama disease) research projects. 



\section{ACKNOWLEDGEMENTS}



"Don't be discouraged. It is often the last key in the bunch that opens the lock". This quote best describes my PhD journey. It was a challenging sail full of discovery and life learnings. Many people I met shaped my personality and life perspectives. First of all, I would like to thank my promotor Prof.Dr.ir.ing. Gert Kema for entrusting me to be part of his group. You influenced me with your extensive scientific expertise, enthusiasm and optimism to handle the daily hurdles and always find a silver lining of every situation. At the start of my PhD when I lost my mother you helped me to change my life's perspective and gave me strength to continue by the grace of our Creator. Your networking, tirelessness, generosity and wisdom is worth emulating. To my co-promotor Dr.ir. Harold Meijer, thank you for leading me the way and your patience to answer all my enquiries and sometimes demands. Our constant discussion was very encouraging and most of the time lead to another research questions that required further investigations. To my local supervisor Dr. Benny Corcolon thank you for your guidance, words of wisdom and motivations. You made my research work in the Philippines easy by connecting me to your team in Tadeco. Dear Gert, Harold and Benny, I am very much honored to be your student.

This book is a result of collaborations with colleagues of different disciplines. I want to send my profuse thanks to the Wageningen University Interdisciplinary Research and Education Fund (INREF) for funding this research project, which enabled me to meet different people from various scientific disciplines. Next to Gert, the other coordinators Dr. Jetse Stoorvogel of the Wageningen Environmental Science group and my fellow PhD students Rafael Segura and Rocky Erima, as well as Dr. Sietze Vellema and Dr. Kees Jansen of the Wageningen Social Science group with their PhD students Marilou Montiflor and Jaye de la Cruz. My direct colleagues Fernando Garcia and Nadia Ordóñez are very much worth mentioning you brightened me through this very challenging time in my life. Our discussions during our meetings, workshops and random discussions were very engaging and helped me to sharpen my concepts. Solving a real-world problem as Panama disease in banana can be best achieved by a multidisciplinary approach. Furthermore, the scientific encounter with my KNAW-SPIN Indonesian PhD collaborators Nani Maryani, Fajar Ahmad, Heni Widinugraheni, Nurmi Pangezti and Iman Nawireja is very much appreciated. To my other fellow PhD colleagues Drs. Caucasella Diaz, Pablo Chong, Lamia Aouini, and Amir Mirzadi Gohari; thank you for the friendship and encouraging discussions during lunch meetings. Meeting people from different parts of the world and learning from their culture is a privilege.

I am very grateful to my Dutch and Philippine collaborators who helped me in conducting this thesis research. To Dr. Cor Schoen and Odette Mendes of Biointeractions and Plant Health, Wageningen Plant Research, thank you for your great help in realizing the LAMP TR4 diagnostic. It was a painstaking experiment to come up with a highly specific assay that we succeeded to share with our partners in the Philippines for on-site TR4 detection. Thanks to Dr. Michael Seidl for your generosity in sharing your bioinformatics cleverness. Many thanks to Joel Mora, Methushella Gaon, Joseph Louyd Tuba, Joy Pondavilla and the rest of the NEH Philippines Inc. research team. You are all appreciated for providing us the place to conduct the field testing of the LAMP diagnostics and the anaerobic field disinfestation 
(ASD) field trials and field sampling. Likewise, I wholeheartedly thank Paul Smits, Hanneke Hermans, Jeroen de Haas and Xiaoqian Shi for their generosity. Our collaborator Clear Detections B.V. was instrumental in the development of SYBR-green based detection of TR4 that I employed in my epidemiological study. The help of Renske Landeweert, Scott Griffiths and Winfried Mulder is acknowledged in the development of diagnostics assay. I am very much grateful to Tadeco research team members Abbeah Mae Navasca and Dennice Catambacan and their colleagues for their untiring support for my field experimentation, in particular the soil and water sampling. I would like to particularly mention my friends Junne Theresa Mercado and Merahflor Ligad for their kind help during my laboratory trials. I am indebted to Bert Catayas and his team for their help in the burning trial and ASD field trial. To the Floirendo family, Mr. Alex Valoria, Mr. Alex Cantil and Dr. Benny Corcolon thank you for your kind support. The other collaborating company Unifrutti Tropical Philippines Inc. is recognized for their valuable support in the field sampling and ASD field experimentation. To Mr. Alberto Bacani, Dr. Lothar Truggelman, Mr. Gary Villa, Lalaine Narreto, Lolit Bacus, Sherman Chavez, Wawai Peńalosa and the rest of the team; your help and generosity was of utmost importance for the completion of this thesis. Dr. Samuel Herbert Mamora and Bikal Ghimire are credited for their great effort in the disinfectant chapter. I am indebted to Mr. Reagan Navarro of Tadeco for providing the protocol for oxidative tests on the metal corrosiveness of disinfectants. I would like to thank Henk Meints and Willemien Runia for their technical guidance in conducting the ASD trial both in the Netherlands and in the Philippines. The assistance of Dr. Jetse Stoorvogel is greatly appreciated for his guidance during the burning trial in the Philippines. The help of Pieter Kastelein is very much appreciated in the preparation of TR4 chlamydospore sachets and his assistance, especially during work in the weekends. Special mention to Blanca Fernandez for her kind help in analysing and characterizing my Philippine soil isolates. Dirk Jan Pasma is recognized for his contribution to soil sampling in the Philippines. I look back with intense thankfulness to the many years of working together and the collaboration with you all.

I would like to thank the people of the business unit Biointeractions and Plant Health, Wageningen Plant Research, for the warm welcome and allowing me to be part of the team. I am thankful to all scientists and technicians for their great help and for the friendship. For the countless queries and requests you kindly attended. To Willem Jan, Peter, Carolien, Stefan, Jose, Petra, Jan, Bram, Anne, Helen, Yvonne, Marc, Ilse, Theo, Cees, Carin, Els N., Odette, Marga, Els V., Trudy, Marjon, Pieter, Joeke, Mirjam, Jolanda, Patricia, Annette, Marieke and Marion thank you for your contribution to my PhD journey. I am very fortunate to have worked with you and look forward to collaborate with you in the future.

My Pinoy friends in Wageningen Leizel, Tess, Maria, Agnes, Tita Nora, Michelle, Vera, Mai, Jean, Eva and their Dutch partners Ruud, Ab, Bert, Eddy, Tito Kees and Ronald are acknowledged for being my family during my stay in the Netherlands. Special mention to Leizel Sangual and her children Patrick, Richael and Richie for welcoming me to your homethank you very much! You blessed me with your care, love and compassion. You comforted me and lifted me up. I know I had found a home away from home. To my fellow Wageningen University students Fe, Lysette, Leolean, Nelben, Methu, Edison, Robby, Connie, Angelo, 
Joyce, Trina, Frazen, Lisa, Rica, Joyce, Laya, Arvee, Arnan and Da Fort - thank you for the memories and always being on standby to talk, to listen and encourage me. For the numerous dinners and Hema breakfasts we shared together which were stress relieving. To my family in the Netherlands Gaga and Adrianne thank you for opening your home as my home.

Above all, I am very much thankful to my beloved family for their ceaseless support and unconditional love. To my husband Michael Jones Niez for allowing me to be far from home and skipping many occasions and special dates to follow my dreams. To my father Mario Salacinas, siblings Mynrio Salacinas and Marc Ryan Salacinas and the entire Salacinas clan thank you for your support, sacrifices and love. To my mother who is now in heaven, I dedicate to you this success - I wish you are here to see your daughter achieving and realizing her dreams. To my parents in-law Miguel and Pacita Niez thank you for your generosity, support, encouragement and prayers. Many hugs to my in-laws Noel and Mitchel Sabay, Marvin and KC Niez, Paul and Mae Ann Niez, Mona Mae Niez and Monette Niez. You guys are my constant support and source of inspiration.

Many thanks to my paranymphs Odette Mendes and Bert Essenstam for your kind help and friendship. You both are instrumental in this success.

Lastly, I would like to express my appreciation to my company Dole Philippines Inc. for allowing me to take days off to travel to Netherlands and finish my book. To our General Manager Oscar Garcia; thank you for entrusting me this job. Your kindness, commitment and passion for work is worth emulating. To my colleagues in the research department and friends; thank you for the support - looking forward for more years working with you all. 


\title{
Education Statement of the Graduate School Experimental Plant Sciences
}

\author{
Issued to: Maricar Salacinas \\ Date: 27 August 2019 \\ Group: Laboratory of Phytopathology \\ University: Wageningen University and Research
}

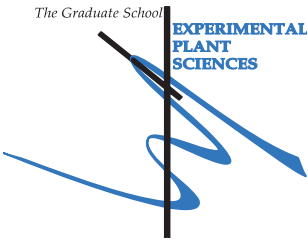

\begin{tabular}{|c|c|c|}
\hline 1) Start-Up Phase & date & $\underline{c p}$ \\
\hline - First presentation of your project & & \\
\hline $\begin{array}{l}\text { Epidemiology and agro-ecology of Fusarium oxysporum f.sp. cubense } \\
\text { Writing or rewriting a project proposal }\end{array}$ & 23 Aug 2013 & 1,5 \\
\hline $\begin{array}{l}\text { Epidemiology and agro-ecology of Fusarium oxysporum f.sp. cubense } \\
\text { Writing a review or book chapter } \\
\text { MSc courses }\end{array}$ & 28 Aug 2013 & 6,0 \\
\hline
\end{tabular}

Subtotal Start-Up Phase

\section{2) Scientific Exposure}

- EPS PhD student days

EPS PhD student days

EPS PhD student days (EPS Get2Gether)

EPS theme symposia

EPS theme 2 symposium

EPS theme 2 symposium

EPS theme 2 symposium

Lunteren Days and other national platforms

Annual meeting Experimental Plant Sciences, Lunteren 2016

28th meeting KNPV Fusarium CBS-KNAW Utrect, Netherlands

Seminars (series), workshops and symposia

INREF project workshop in Ede, Netherlands

INREF project workshop in Asia, Davao, Philippines

INREF project workshop at WUR campus, Netherlands

3rd Wageningen PhD symposium, WUR, Netherlands

Wageningen Banana Day and Masterclass with Prof. Ivan Buddenhagen, WUR, Netherlands

(1)

Seminar plus

- International symposia and congresses

6th International Banana Congress CORBANA and XXI International meeting ACORBAT, Miami, USA ICAEM Conference, Davoa, Philippines

qPCR congress, London, UK

IPMB alumni meeting, Can Tho University, Vietnam

Satellite meeting on Fusarium wilt disease of banana, Boston, USA

ICPP Congress Boston, USA

- Presentations

Talk - Detection and quantification of Foc TR4 in soil and water, ICAEM Conference, Philippines Poster - DNA-based detection of Foc TR4 in soil and water, Host-Microbe Interactomics, WUR, Netherlands

Talk - Epidemiology and agro-ecology of Fusarium oxysporum f.sp. cubense, Banana Program Masterclass, WUR, Netherlands

Talk - Diagnostics in minutes or hours: track and trace Foc TR4 spread, 6th International Banana Congress CORBANA and XXI International meeting ACORBAT, Miami, USA

Poster - Diversity Array Technology Sequencing of Foc for developing a TaqMan real time PCR assay, qPCR congress, London UK

Talk - Panama disease: a menace to global banana production, IPMB alumni meeting, Vietnam

Talk - Genotyping by sequencing to identify diagnostic regions in Foc TR4 and applications in disease epidemiology, ICPP Congress Boston, USA

Talk - In field dissemination of Foc TR4 and inoculum management, Satellite meeting on Fusarium wilt disease of banana, Boston, USA

date

29 Nov 2013

28-29 Jan 2016

$\underline{c p}$

AB interview

25 Feb 2014

22 Jan 2016

23 Jan 2017

11-12 Apr 2016

29 Oct 2014

23-24 Sep 2013

6-7 Feb 2014

6-7 Jul 2015

26 Apr 2016

19-20 Nov 2014

2-3 Sep 2014

3 Jun 2014

20 Nov 2014

20-22 Apr 2016

20-21 Oct 2016

18-21 Sep 2016

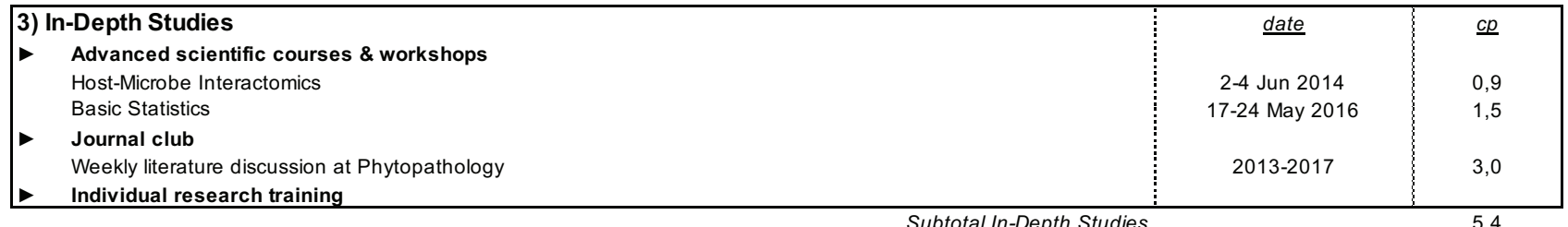




\section{4) Personal Development}

General skill training courses

Project and Time Management

Data Management

Mini-symposium - how to write a world-class paper

Information Literacy including Endnote

Brain Training

Research integrity

Symposium Publish for Impact

Scientific publishing

Organisation of meetings, PhD courses or outreach activities

Membership of EPS PhD Council

\begin{tabular}{|c|c|c}
\hline$\underline{c p}$ & $\underline{c}$ \\
& & 1,5 \\
17 Sep - 29 Oct 2013 & 0,3 \\
8 Oct 2013 & 0,2 \\
17 Oct 2013 & 0,6 \\
9-10 Jun 2016 & 0,3 \\
1 Jun 2016 & 0,6 \\
17-18 Oct 2016 & 0,3 \\
13 Oct 2016 & 0,3 \\
& 19 Oct 2017 & CONTINUED ON NEXT PAGE \\
\hline & & \\
\hline
\end{tabular}

TOTAL NUMBER OF CREDIT POINTS*

35,0

Herewith the Graduate School declares that the PhD candidate has complied with the educational requirements set by the Educational Committee of EPS with a

minimum total of 30 ECTS credits.

${ }^{*}$ A credit represents a normative study load of 28 hours of study. 
The research described in this thesis was financially supported by the Interdisciplinary Research and Education Fund (INREF) program of Wageningen University \& Research and the Dutch Dioraphte Foundation.

Financial support from Wageningen University for printing this thesis is gratefully acknowledged.

Cover design and layout by Loes van de Kraats - Kema

Printed by GVO drukkers \& vorngevers, Ede, The Netherlands 